\title{
Pais, Adolescentes e Autonomia Moral: Escala de Concepções Educativas
}

Tese de doutorado apresentada ao Instituto de Psicologia da Universidade de São Paulo, como parte dos requisitos para obtenção do título de Doutor em Psicologia.

Área de concentração: Psicologia Escolar e do Desenvolvimento Humano

Orientadora: Professora Associada Maria Thereza Costa Coelho De Souza

São Paulo - SP 
AUTORIZO A REPRODUÇÃO E DIVULGAÇÃO TOTAL OU PARCIAL DESTE TRABALHO, POR QUALQUER MEIO CONVENCIONAL OU ELETRÔNICO, PARA FINS DE ESTUDO E PESQUISA, DESDE QUE CITADA A FONTE.

Catalogação na publicação

Biblioteca Dante Moreira Leite

Instituto de Psicologia da Universidade de São Paulo

Caetano, Luciana Maria.

Pais, adolescentes e autonomia moral: escala de concepções educativas / Luciana Maria Caetano; orientadora Maria Thereza Costa Coelho de Souza. -- São Paulo, 2009.

$249 \mathrm{p}$.

Tese (Doutorado - Programa de Pós-Graduação em Psicologia. Área de Concentração: Psicologia Escolar e do Desenvolvimento Humano) - Instituto de Psicologia da Universidade de São Paulo.

1. Desenvolvimento moral 2. Educação moral 3. Adolescentes 4. Papel dos pais 5. Avaliação psicológica 6. Piaget, Jean, 1896-1980 I. Título.

BF723.M54 


\section{FOLHA DE APROVAÇÃO}

Luciana Maria Caetano

Pais, Adolescentes e Autonomia Moral: Escala de Concepções Educativas

Tese de doutorado apresentada ao Instituto de Psicologia da Universidade de São Paulo, como parte dos requisitos para obtenção do título de Doutor em Psicologia.

Área de concentração: Psicologia Escolar e do Desenvolvimento Humano

Tese defendida e aprovada em

Banca Examinadora

Prof. Dr.

Instituição: Assinatura:

Prof. Dr.

Instituição: Assinatura:

Prof. Dr.

Instituição: Assinatura:

Prof. Dr.

Instituição: Assinatura:

Prof. Dr.

Instituição: Assinatura: 
DEDICATÓRIA

Para Antonio e Wilma, meu pai e minha mãe, com todo o meu amor. 


\section{AGRADECIMENTOS}

À professora Maria Thereza Costa Coelho de Souza, orientadora dessa tese, por toda a sua dedicação, atenção, apoio e amizade ao longo dessa caminhada.

Ao professor Dirceu da Silva, pela orientação com relação aos métodos quantitativos e todo o seu generoso apoio.

Aos professores Yves de La Taille, Ana Paula Porto Noronha, Maria de Fátima Lukjanenko, Eliete Aparecida de Godoy, pelas importantes contribuições para com este trabalho.

A todos os professores que participaram do meu percurso como pesquisadora.

As amigas Ana Flávia e Betânia, pela partilha de conhecimentos, pelo companheirismo e toda a generosidade da amizade.

As colegas de orientação da professora Maria Thereza e do LEDA, especialmente o querido amigo Fernando.

Aos diretores, coordenadores e professores que viabilizaram com carinho e solicitude a coleta dos dados nas diferentes escolas do país e aos amigos que me abriram caminhos para os contatos como essas escolas: Edgar, Romeu, Rosângela, Silvia, Michelli, Fabiana, Lenize, Rose, Mariângela, Izidoro, Rinaldi, Evânio, Cintya, Sueli, Fabiana.

Ao meu marido Paulo, por seu amor e carinho, por seu exemplo como pesquisador, pelo seu incentivo constante, e especialmente, por toda ajuda preciosa em relação a minha formação acadêmica.

Aos meus pais pelo apoio incondicional e pelo carinho de sempre, tão necessários, especialmente em dias cinzentos.

À minha querida amiga Antonia Euclédia, por ter estado presente em todos os passos desse caminho, sempre solícita e generosa.

A querida Cleonice por sua sabedoria e por suas orações.

Aos meus familiares e amigos, por caminharem ao meu lado.

Aos funcionários do Instituto de Psicologia e aos funcionários do xérox: José e Claúdio.

A FAPESP (Fundação de Amparo a Pesquisa do Estado de São Paulo) pelo financiamento da presente pesquisa. 
Para educar a autonomia na criança, portanto, é útil "educá-la" cientificamente. Mas não basta, para isso, submetê-la à sociedade adulta, e fazê-la compreender de fora as razões da submissão: a autonomia é um poder que só se conquista de dentro e que só se exerce no seio da cooperação.

Jean Piaget, 1932 


\section{RESUMO}

Caetano, L. M. (2009). Pais, Adolescentes e Autonomia Moral: Escala de Concepções Educativas. Tese de Doutorado, Instituto de Psicologia, Universidade de São Paulo, São Paulo.

A proposta desse estudo foi desenvolver e validar um instrumento de avaliação psicológica que permitisse a investigação dos conceitos dos pais sobre a sua participação na construção da autonomia moral dos seus filhos adolescentes. O trabalho teve como base teórica a Teoria do Desenvolvimento Moral de Jean Piaget. Conforme a teoria do Desenvolvimento Moral de Jean Piaget a construção da autonomia é um possível caminho de evolução para o pensamento adolescente. O conceito de autonomia é definido no contexto relacional, em outras palavras, a grande proposta desse processo é a construção de um eu adaptado ao coletivo. As questões que nortearam esta pesquisa foram: $O$ que os pais pensam sobre a sua participação na construção do desenvolvimento da autonomia moral dos seus filhos adolescentes? Que tipos de intervenções representam os seus conceitos sobre: obediência, respeito, justiça e autonomia? O processo de construção e validação do instrumento foi conduzido através dos seguintes passos: construção da escala com assertivas para cada construto, Estudo Piloto realizado para proceder a Validação Semântica, Validação Teórica (a escala foi avaliada por juízes - especialistas no campo da moralidade e da psicometria); Validação de Construto (Análise Fatorial Confirmatória). A amostra se constituiu de 860 genitores, pais $(20,6 \%)$ e mães $(79,4 \%)$ de adolescentes com idades entre doze e vinte anos. Havia participantes de cada uma das cinco regiões do país (42,8\% do sudeste, $20,2 \%$ do nordeste, $16,5 \%$ do centro-oeste, $11 \%$ do norte, e 9,3\% do sul) e a pesquisa com os pais foi realizada no ambiente escolar (54,8\% na escola pública e $45 \%$ na privada). O modelo da escala tinha 36 assertivas. Estas assertivas foram delineadas representando os quatro construtos: obediência, respeito, justiça e autonomia. Os participantes atribuíram nota de 1 a 7 (respectivamente as opções com as quais eles discordaram totalmente e aquelas com as quais eles concordaram totalmente). A Análise Fatorial Confirmatória (LISREL) indicou a propriedade dos quatro fatores: respeito obediência, justiça e autonomia (GFI $\left.=0,933, \mathrm{x}^{2} / \mathrm{gl}=5,2, \mathrm{RMSEA}=0,0702\right)$. A Escala de Concepções Educativas (depois da validação estatística, AFC), finalizou com 25 itens, sendo 4 itens para obediência, 5 itens para respeito, 8 itens para justiça e 8 itens para autonomia. Por conseguinte os resultados da validação de construto forneceram um maior número de itens para autonomia em detrimento da obediência e forneceram um número maior de itens para justiça, que é para Piaget, a mais racional da todas as noções morais, a qual parece ser o resultado direto da cooperação.Os resultados indicaram que as concepções educativas dos pais têm uma tendência para proporcionar a autonomia para os filhos. Mas, os resultados revelaram que houve uma considerável diferença entre as concepções educativas e as intervenções concretas dos pais e seus filhos. Os resultados desse estudo mostraram que a maior dificuldade dos pais para educar para a autonomia moral diz respeito aos tipos de punição, portanto, um problema de justiça retributiva. Os participantes dessa pesquisa demonstraram que eles desejam educar seus filhos para a autonomia, mas suas intervenções não concordam com seus objetivos.

Palavras-chave: 1 . Desenvolvimento moral 2. Educação moral 3. Adolescentes 4. Papel dos Pais 5. Avaliação Psicológica 6. Piaget, Jean, 1896-1980 


\begin{abstract}
Caetano, L. M. (2009). Parents, Adolescents and Moral Autonomy: Educative Conceptions' Scale. Tese de Doutorado, Instituto de Psicologia, Universidade de São Paulo, São Paulo.

The purpose of this study was to develop and validate an instrument for psychological evaluation that allowed the investigation of the parents' concepts about their participation on the construction of their adolescent children's moral autonomy. The research had as its theoretical basis Piaget's Moral Development Theory. According to Piaget's moral development theory the autonomy construction is the possible evolutionary way for the adolescent's thought. The concept of autonomy is defined in the contextual relationship, in other words, the greatest purpose of this process is the moral construction of one's self adapted to social. The questions which supported this research were: What do parents think about their participation on the construction of their adolescent children's moral autonomy? What kind of interventions represented their conceptions about: obedience, respect, justice and autonomy? The process of construction and validation of the instrument was being carried out via the following steps: construction of the scale with assertions for each construct; pilot study in order to arranged semantic validation; theoretical validation (the scale was evaluated by judges - scholars in the field of morality and psychometrics); construct validation (Confirmatory Factor Analysis). The sample consisted of 860 parents, fathers $(20,6 \%)$ and mothers $(79,4 \%)$ of teenagers between the ages of twelve and twenty years old. There were participants from each one of the five different regions in Brazil (42,8\% south-eastern, 20,2\% northeastern, $16,5 \%$ middle west, $11 \%$ north, and 9,3\% south) and the research with the parents was done on school grounds (54,8\% public and $45, \%$ private schools). The scale model had 36 assertions. These assertions were delineated representing the four constructs: obedience, respect, justice and autonomy. The participants attributed notes from 1 to 7 (respectively the options with which they disagree totally and those with which they agree totally). The Confirmatory Factor Analysis (LISREL) indicated the appropriateness of the four constructs: respect, obedience, justice and autonomy (GFI = 0,933, $\mathrm{x}^{2} / \mathrm{gl}=5,2, \mathrm{RMSEA}=$ 0,0702). The Educative Conceptions Scale (after statistical validation, CFA) finalized with 25 items, being, 4 items for obedience, 5 items for respect, 8 items for justice, and 8 items for autonomy. Therefore the results of construct validation provided a larger number of items for autonomy, too the detriment of obedience, and provided a larger number of items for justice, that is to Piaget, the most rational of all moral notions, which seems to be the direct result of cooperation. The results indicated that the parents' educative conceptions have a tendency to arrange autonomy for teenagers. But, the results revealed that there was a considerable difference between the educative concepts and the real interventions of parents and their teenagers. The results of this study showed that the parents' main difficulty to educate moral autonomy disrespects the types of punishment, therefore a problem of retributive justice. The participants of this research demonstrated that they wish to educate their children for autonomy but their interventions did not agree with their aims.
\end{abstract}

Keywords: 1. Moral development 2. Moral education 3. Adolescents 4. Moral Education 5. Psychological Evalution 6. Piaget, Jean, 1896-1980 


\section{LISTA DE QUADROS}

QUADRO 1 Tipos de validade utilizada pela testagem psicológica

QUADRO 2 Etapas para a elaboração de um

instrumento de avaliação psicológica

QUADRO 3 Escala de Concepções Educativas: versão do instrumento aplicado na amostra de 860 participantes com crivo da autora ----

QUADRO 4 Instrumento na sua primeira versão

QUADRO 5 Graduações da avaliação

do instrumento

QUADRO 6 Escala de Concepções Educativas -----------------------------------

QUADRO 7 Modelo do Instrumento: construtos e seus respectivos itens

QUADRO 8 Medidas de ajustamento do modelo

QUADRO 9 Medidas do modelo ajustado

QUADRO 10 Gráfico do Modelo Final Ajustado

QUADRO 11 Modelo Final da Escala de

Concepções Educativas

QUADRO 12 Histogramas comentados dos itens que compõem o Construto de Obediência

QUADRO 13 Histogramas comentados dos itens que compõem o

Construto de Respeito

QUADRO 14 Histogramas comentados dos itens que compõem o

Construto de Justiça

QUADRO 15 Histogramas comentados dos itens que compõem o

Construto de Autonomia 


\section{LISTA DE TABELAS}

TABELA 1 Estatísticas descritivas dos dados

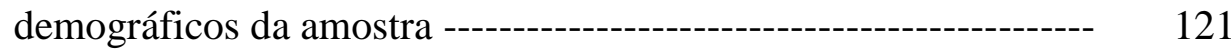

TABELA 2 Estatísticas descritivas da distribuição

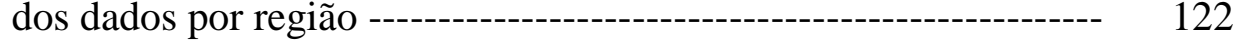


INTRODUÇÃO - --

1 ADOLESCÊNCIA E A CRISE DA EDUCAÇÃO --------------------- 17

2 ADOLESCÊNCIA: CONCEITOS, TEORIAS E PESQUISAS ------- 28

3 ADOLESCÊNCIA E A RELAÇÃO PAIS E FILHOS --------------- 50

4 ADOLESCÊNCIA E A CONSTRUÇÃO DA AUTONOMIA MORAL

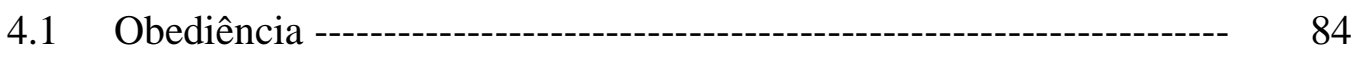

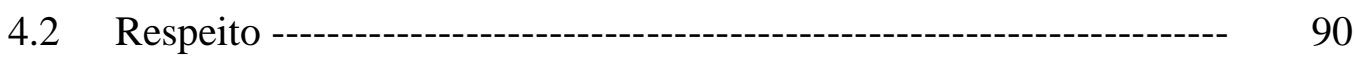

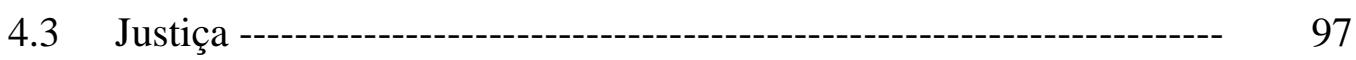

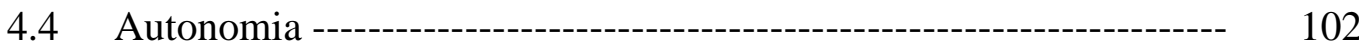

5 SOBRE A CONSTRUÇÃO DE INSTRUMENTOS DE AVALIAÇÃO

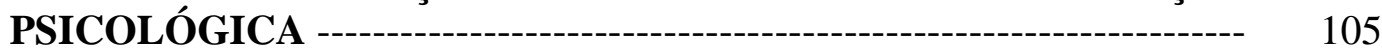

5.1 Fundamentos da elaboração e validação de testes de avaliação psicológica: da psicometria ------------------------------------- 105

5.2 Os instrumentos de investigação moral ------------------------- 111

5.3 Os instrumentos que avaliam as práticas e estilos parentais --------- 114

6 PAIS, ADOLESCENTES E AUTONOMIA MORAL: ESCALA DE CONCEPÇÕES EDUCATIVAS --- 118

6.1 A pesquisa: problemas e objetivos -------------------------------------- 118

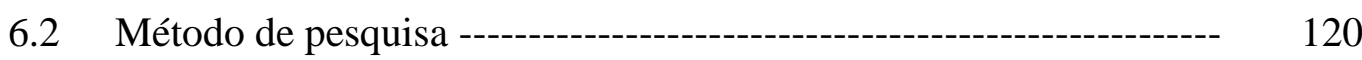

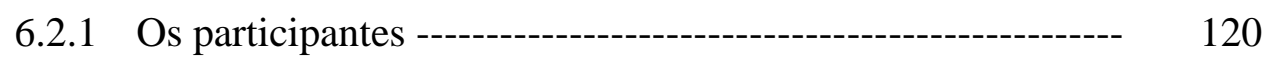

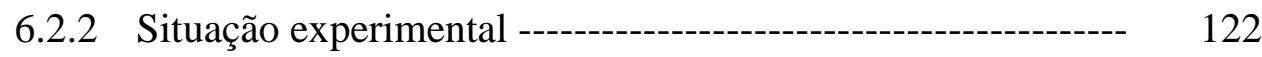

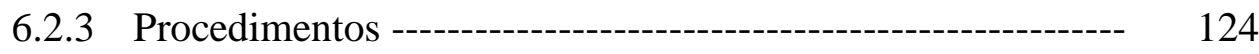

7 CONSTRUÇÃO E VALIDAÇÃO DA ESCALA DE CONCEPÇÕES

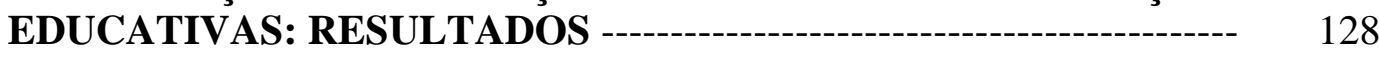

7.1 Validade de conteúdo --------------------------------------------------- 129

7.2 Validade de construto --------------------------------------------------- 140 
8.1 O instrumento e ao que ele responde: discussão dos resultados ----- $\quad 150$

8.1.1 Sobre o Modelo Final do Instrumento - --a- 150

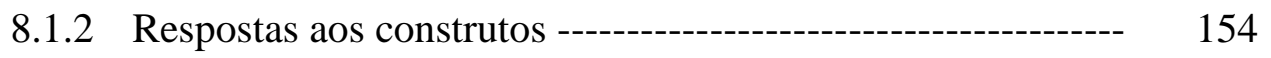

8.1.3 Sobre os itens ou variáveis eliminados --------o---------- 182

8.2 Estudo das tendências segundo as variáveis dependentes ----------- $\quad 184$

8.2.1 Variáveis que não apresentaram significância estatística ---- 185

8.2.2 Variáveis que apresentaram significância estatística -------- 188

9 CONSIDERAÇÕES FINAIS --

REFERÊNCIAS BIBLIOGRÁFICAS---------------------------- 211

ANEXOS ------

A Termo de Consentimento Livre e Esclarecido --------------------- 225

B Instrumento com crivo, versão aplicada pelo estudo piloto --------- 227

C Caracterização dos participantes do estudo piloto ------------------ 231

D LISREL (Resultados estatísticos da Análise Fatorial 232

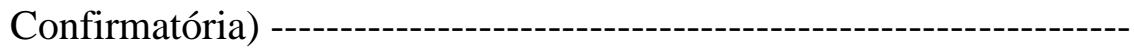




\section{INTRODUÇÃO}

A pesquisa que se apresenta tem como objetivo, construir e validar um instrumento de avaliação psicológica, que mensure os conceitos determinantes da intervenção dos genitores no processo de construção da autonomia moral dos filhos, apoiado e convergente com o referencial teórico fundamental desse trabalho que é a teoria do desenvolvimento moral de Jean Piaget. (1930, 1932, 1948, 1954, 1964, 1970).

A proposta de construção de um novo instrumento se justifica pela escassez de instrumentos voltados para a temática da moralidade, especialmente, pelo fato de se pretender a originalidade de um instrumento coerente com a teoria piagetiana do desenvolvimento moral, e, que, por outro lado, se constitua em um instrumento que possibilite abordar uma amostragem considerável de participantes e realizar também um tratamento estatístico que garanta à pesquisa a análise quantitativa e a generalização de seus resultados.

O primeiro capítulo apresenta a justificativa da temática: a crise da educação. $O$ tema da adolescência traz imbuído em si, desde o senso comum, o conceito de crise, conflito e divergência. Obviamente, ao se pensar o tema da adolescência atrelado ao papel dos pais na educação e formação dos jovens, novamente as dificuldades são vislumbradas e explicitadas pela mídia, pela literatura sobre o tema, e também novamente pela opinião coletiva.

Uma pesquisa realizada com pais de crianças pequenas (Caetano, 2008), apresenta nos seus resultados, as dificuldades inerentes ao processo de educar crianças pequenas para a moralidade. Uma vez que pais e mães se sentem confusos e pouco seguros no período no qual as crianças são inseridas no mundo das regras, ao que se pode chamar, gênese da moral; como poderão ajudar os seus filhos a construírem a autonomia moral, fruto de relações pautadas em respeito mútuo e justiça? Qual a participação dos pais na problemática da crise da educação? Esse capítulo buscará, algumas respostas na filosofia, mais especificadamente no texto "A crise da educação" da filósofa Hannah Arendt (1964/2005), enquanto parâmetro e argumento para a discussão da temática da crise no processo educativo.

O segundo capítulo apresenta a revisão das principais teorias psicológicas que se debruçaram sobre o estudo da adolescência, como fase de desenvolvimento humano. Esse capítulo define ainda o conceito de adolescência e discute as tendências das pesquisas realizadas a respeito de tal tema.

O segundo capítulo discute também a abordagem psicanalítica enquanto teoria fundadora dos estudos da adolescência, e, embora essa não seja a opção teórica que 
fundamentará a presente pesquisa, aponta a sua relevância em um capítulo cujo objetivo é apresentar os aspectos conceituais, bem como revisão das teorias e pesquisas sobre o tema.

O terceiro capítulo revisa a literatura sobre a temática da relação entre pais e adolescentes. O tema relação pais e adolescentes esteve inicialmente fundamentado na questão da conexão versus separação. Uma vez que a adolescência foi inicialmente compreendida como um período de tempestade e tormenta, a relação parental foi sempre considerada como situação de considerável conflito, que deveria terminar com a separação do adolescente de seus pais. Todavia o desenvolvimento das pesquisas sobre o tema, levou a um entendimento diferenciado dessa relação parental: a adolescência passou a ser interpretada como mais uma fase do desenvolvimento humano, e, a relação com os pais pôde ser compreendida na possibilidade de reconstrução em um patamar de respeito mútuo e reciprocidade.

A ênfase nesse capítulo é dada, portanto, às pesquisas da abordagem cognitivista, que concordam com essa última maneira de estudar a adolescência, enquanto uma fase do desenvolvimento humano com suas particularidades, mas não necessariamente, fase de crises, conflitos e, especialmente, total desconexão com os familiares. Esse capítulo enfatiza também, especialmente, a perspectiva teórica piagetiana sobre o desenvolvimento do adolescente, uma vez que essa é a teoria escolhida para a fundamentação teórica dessa pesquisa.

A temática do desenvolvimento moral do adolescente é retomada no quarto capítulo. Para Piaget a construção de um conjunto de valores conservados e hierarquizados é fruto do desenvolvimento cognitivo, afetivo e moral do adolescente e lhe permitirá a construção de uma personalidade e de um plano de vida que o inserirá no mundo coletivo enquanto pessoa autônoma, moral e cognitivamente.

Portanto, o quarto capítulo tem a especial função de apresentar os principais fatores que influenciam a construção da autonomia moral da adolescência: respeito, obediência, justiça e autonomia. Sendo assim, esse capítulo também se destina a fundamentação teórica dos itens das escalas, que são previamente apresentados reunidos nos respectivos construtos. Os itens são explicados e discutidos no interior do texto, a partir das respectivas justificativas para a sua definição.

O quinto capítulo divide-se em três partes. A primeira parte tem como objetivo apresentar as indicações da psicometria que foram utilizadas pela investigação para a elaboração do instrumento, a definição dos processos de validação, a escolha dos processos de análise teórica e análises estatístiscas. 
A segunda parte, tem por objetivo apresentar os instrumentos de investigação moral existentes, discutindo algumas questões a respeito das suas propriedades, de modo a justificar a construção de um novo instrumento e inseri-lo no contexto dos outros instrumentos existentes.

Finalmente, a terceira parte do quinto capítulo, objetiva apresentar um resumo e breve discussão sobre os instrumentos (que somam mais de 100) de investigação de práticas e estilos parentais, utilizados pela abordagem comportamental, discutindo os seus objetivos e finalidades e comparando a proposta do instrumento que a presente pesquisa se designou a elaborar.

Todo o processo de delineamento da pesquisa, bem como a pergunta que a orienta, seus objetivos principais e específicos são expostos no sexto capítulo. Este capítulo apresenta também a descrição do método da pesquisa, caracterizando seus participantes, a situação experimental, os procedimentos para a coleta e análise dos dados. A versão do instrumento, apresentada nesse capítulo, é fruto da validação de conteúdo e foi a versão aplicada na amostra de 860 sujeitos, para dar sequiência a validação de construto através da análise estatística dos dados. Essa versão conta com o crivo da pesquisadora.

O sétimo capítulo intitulado de Resultados, se subdivide em três partes. A primeira descreve todo o processo de construção do instrumento, através da definição do domínio, dos construtos e dos itens. A primeira versão do instrumento é apresentada nesse capítulo. A segunda parte do capítulo descreve a validação teórica do instrumento, apresentando todas as alterações e reorganizações do mesmo, propostas pelos juízes (professores doutores especialistas em desenvolvimento moral, métodos de pesquisa qualitativa e avaliação psicológica), bem como os resultados do estudo piloto.

Finalmente, a terceira parte, descreve a análise estatística do instrumento, realizada através da Análise Fatorial Confirmatória, que permitiu apurar a representatividade dos itens diante de cada construto. O resultado desse processo de validação do instrumento é justificado pela apresentação das medidas de ajustamento do modelo. Esse capítulo também apresenta Versão Final do Instrumento, depois da validade dos construtos.

O oitavo capítulo dessa tese apresenta a discussão dos resultados, e também se subdivide em duas partes. A primeira discute todo o processo de validação dos construtos, através de uma análise qualitativa (amparada pela análise estatística) do processo de construção e validação do instrumento à luz da teoria do juízo moral de Jean Piaget. O modelo final é discutido buscando compreender psicologicamente porque alguns itens são eliminados do 
instrumento e qual a importância enquanto medida psicológica daqueles que permaneceram enquanto itens representativos dos seus construtos.

A idéia dessa parte do capítulo é formatar um mapa de observações a respeito das concepções educativas dos pais e mães de adolescentes, em uma perspectiva nacional, objetivando apontar possíveis validações convergentes dos resultados, e especialmente, realizar um levantamento da maneira como pensam a educação dos seus filhos adolescentes no que diz respeito a como estabelecem as relações de respeito, obediência, justiça e autonomia com seus filhos.

A segunda parte, por sua vez, discute a existência ou não de significâncias estatísticas em relação às variáveis: gênero, número de filhos, estado civil, profissão e escolaridade dos pais, estado civil e idade dos participantes; quando relacionadas às respostas aos constructos, bem como a existência ou não de significâncias estatísticas em relação às variáveis: tipo de escola na qual os adolescentes estudam (pública e privada) e lugares pesquisados (regiões sul, norte, nordeste, centro-oeste, sudeste do Brasil); quando relacionadas às respostas aos construtos.

O último capítulo, intitulado de Considerações finais, tem a ambição de oferecer uma reflexão a respeito dos temas que nortearam a presente investigação, no intuito de discutir suas hipóteses, à luz dos dados colhidos, a respeito da existência ou não de uma crise de educação na relação entre pais e adolescentes brasileiros, especialmente na temática da educação moral, compreendida pelo autor que fundamenta essa pesquisa, Jean Piaget, como tendo como finalidade máxima a formação de adultos autônomos.

O nono capítulo tem, portanto, o intuito ainda de responder as seguintes questões: $\mathrm{O}$ presente instrumento elaborado por essa pesquisa, permitiu avaliar se os pais e mães brasileiros tendem a formar os adolescentes para a construção da autonomia moral? Terminada a pesquisa, o que pode ser dito aos pais dos adolescentes do nosso país?

E, finalmente, essa pesquisa ainda se propõe a refletir de forma indireta sobre a participação da escola nessa temática da atuação e participação dos pais na educação moral dos adolescentes. Todos os dados dessa pesquisa foram colhidos no ambiente escolar, uma vez que não se conseguiu imaginar outro espaço, que não fosse a escola, no qual fosse possível reunir os participantes dessa pesquisa: pais e mães de adolescentes de 12 a 20 anos.

Portanto, não se pode negar a importância do tema da relação família e escola, tão pouco estudado e investigado para essa pesquisa. A realização dessa pesquisa foi organizada modo particular, pela própria natureza do convite feito aos participantes da investigação, de, em 
meio a uma reunião de pais, na escola na qual os seus filhos estudavam, responderem sobre como pensam a sua participação no tocante a educação moral dos seus filhos.

Portanto, a ambição dessa investigação é ouvir os pais e mães de adolescentes (contando com amostra das cinco regiões do país), buscando para isso um instrumento de avaliação psicológica, que permita compreender as concepções educativas dos pais deles, no tocante as relações de obediência, respeito, justiça e autonomia que estabelecem com seus filhos. 


\title{
1 ADOLESCÊNCIA E A CRISE DA EDUCAÇÃO
}

\begin{abstract}
Essa responsabilidade não é imposta arbitrariamente aos educadores; ela está implícita no fato de que os jovens são introduzidos por adultos em um mundo em contínua mudança. Qualquer pessoa que se recuse a assumir a responsabilidade coletiva pelo mundo não deveria ter crianças, e é preciso proibi-la de tomar parte em sua educação. (Hannah Arendt, 1964/2005, p.239)
\end{abstract}

Existe um significativo desconforto social, no que concerne a esta temática da adolescência e a relação entre pais e filhos. $O$ discurso do senso comum afirma com um saudosismo exacerbado, que os pais de hoje não sabem mais educar os filhos, não lhes transmitem valores, não disciplinam as crianças, daí os grandes problemas vivenciados com os adolescentes.

Três exemplos clássicos, amplamente divulgados pela mídia e extremamente comentados são: o caso dos adolescentes que colocaram fogo em um índio em Brasília, pensando que o mesmo fosse mendigo, o caso da adolescente que em cumplicidade com o namorado matou seus pais, pois eles eram contrários ao namoro; e, finalmente, o mais recente de todos, o dos jovens que espancaram a empregada doméstica que aguardava a condução coletiva, argumentando que pensaram que a mesma fosse prostituta.

Obviamente há que se fazer sempre a distinção entre o que é normal e o que é patológico, na adolescência, competência essa, nem sempre bem efetuada pelos pais, porém, os exemplos têm a função de ilustrar a importância da devida participação dos pais neste momento essencial da vida da pessoa, e o quanto a negligência, a indiferença, ou o autoritarismo, podem ser perniciosos ao desenvolvimento do jovem.

Mas, o que sabem os pais a respeito da chamada adolescência? Ou talvez seja mais prudente questionar, o que sabem os pais sobre o desenvolvimento dos seus filhos? Segundo as palavras de Sayão $\left(2003\right.$, p.111 ${ }^{1}$ :

Fico impressionada com a quantidade de correspondências que recebo de pais de adolescentes. Cada um tem uma questão diferente a discutir, uma dúvida específica sobre como agir em determinada situação, uma idéia diversa a respeito da educação que deve praticar com os filhos. Mas todos têm, em comum, uma idéia muito interessante: a de que ter filhos adolescentes é um grande problema. Será que é mesmo?

\footnotetext{
${ }^{1}$ Rosely Sayão é psicóloga e consultora educacional, colunista do Jornal Folha de São Paulo, e autora do livro “Como educar meu filho?", no qual reúne os artigos publicados no mesmo jornal, nos anos de 2000 a 2002. Este trecho é retirado do artigo que se intitula: "Para viver estressados como vocês? Não obrigado", do mesmo livro.
} 
Talvez o que seja mais difícil dos pais admitirem é o fato de que, a fase da adolescência tem realmente os seus desafios, as suas especificidades. Todavia a educação é um processo que se inicia muito anteriormente a essa fase do desenvolvimento, e, portanto, além de todas as circunstâncias e confrontos peculiares à adolescência, os pais estarão colhendo também o resultado dos seus cuidados com os filhos durante toda a sua infância. Conforme os estudos de Winnicott (1986/2005, p.152), que também discute a importância da tarefa dos pais junto ao processo de desenvolvimento vivenciado na puberdade, confrontado com as angústias da adolescência:

Quando olhamos para a adolescência, na qual, os êxitos e as falhas aos cuidados ao bebê e à criança vêm à baila, alguns dos problemas que enfrentamos na atualidade têm relação com os elementos positivos da moderna educação de filhos e as atitudes modernas referentes aos direitos dos filhos.

O autor afirma também que, não se pode contar com a idéia de que se tudo correu bem na criação da criança, não haverá problemas na adolescência, pois para ele certos problemas como agressividade são inerentes, bem como, a imaturidade do adolescente, que para ele é extremamente saudável. Portanto, os pais precisam ser capazes de lidar com resultados incríveis, pois a imprevisibilidade da educação é uma constatação. Segundo suas palavras:

É claro que meninos e meninas podem dar um jeito de atravessar essa fase por meio de uma série de acordos com os pais e sem necessariamente manifestar rebelião em casa. No entanto, é prudente lembrar que a rebelião pertence à liberdade que vocês deram a seus filhos, quando os criaram de modo que eles existissem por si próprios. Poder-se-ia dizer, em alguns momentos: "Você semeou um bebê e colheu uma bomba'. A rigor, isso é sempre verdade, mas nem sempre aparece assim. (Winnicott, 1986/2005, p.152)

A educação das crianças é, portanto, uma tarefa árdua e desafiadora para a maioria dos pais e mães que não sabem exatamente como proceder. Alguns recorrem a livros de autoajuda, outros se espelham nos seus próprios pais, o que nem sempre representa o melhor caminho, a maioria age de modo empírico, isso é, vai educando num processo de ensaio e erro. Nos dias atuais as dificuldades parecem se multiplicar devido às transformações do mundo moderno.

Conforme a pesquisa de Caetano (2008) que investigou pais de crianças pequenas a respeito do que pensam sobre a obediência e a educação moral de seus filhos ${ }^{2}$, a questão da

\footnotetext{
${ }^{2}$ Esse trabalho tem como fonte de dados a pesquisa intitulada: Os conceitos morais de pais e mães de crianças pequenas: um estudo sobre a obediência, apresentada ao Instituto de Psicologia da Universidade de São Paulo,
} 
insegurança e desconhecimento dos pais sobre as fases do desenvolvimento dos filhos, e a consciência das conseqüências de suas intervenções, são aspectos relevantes demonstrados a partir dos resultados. Assim, quando questionados a respeito do que pensam sobre o problema da desobediência infantil, os pais apresentam as seguintes respostas:

- Alguns assumem com grande franqueza que resolvem o problema da desobediência dos filhos através de tentativas, ou seja, primeiramente tentam dialogar com eles, quando isso não dá resultado, eles afirmam castigar as crianças, negando-lhes temporariamente algo que eles gostam, como por exemplo, televisão, vídeo-game, ou um brinquedo, finalmente, quando nada disso resolve, afirmam que acabam resolvendo a desobediência com a agressão física, que não é reconhecida pelos mesmos dessa forma, mas como um ato que possui uma função educativa.

- Outros admitem que o diálogo é a melhor forma de solucionar as desavenças com os filhos, todavia, dizem que não conseguem necessariamente colocar isso em prática, ou, mais do que isso, parece que suas palavras nem sempre surtem efeito. Então, quando as palavras não funcionam, eles afirmam que partem para os castigos, e, admitem que, quando os castigos também não obtêm sucesso, eles acabam agredindo as crianças. E, realmente afirmam que, existem ocasiões nas quais, “as crianças pedem para apanhar". (Caetano, 2008, p. 144).

- Ainda há os pais que respondem que um bom pai deve punir os seus filhos, ou seja, o bom pai deve cercear o comportamento inadequado do filho, seja da forma que for, nem que tenha que falar mais alto, que dar broncas, que fazer ameaças e se necessário admitem até mesmo que optam pelos "tapas".

- Mas, também há aqueles que admitem que o bom pai dialoga com o filho, buscando explicar as regras e ouvir as suas explicações para compreender o que a criança está pensando. Esses pais afirmam que é fundamental que se tenha a certeza da compreensão por parte das crianças, das regras que estão sendo ensinadas pelos pais.

Assim, os dados da pesquisa acima demonstram uma dificuldade declarada por parte de pais e mães de crianças pequenas a respeito de como educar os seus filhos, que valores lhes ensinar e como fazer valer esses valores. A temática da crise na educação se faz presente nos

como parte dos requisitos para obtenção do título de Mestre, na área de concentração: Psicologia Escolar e do Desenvolvimento Humano, sob a orientação da professora Associada Maria Thereza Costa Coelho De Souza, do mesmo Instituto. Tal pesquisa encontra-se publicada: Caetano, L. M (2008). O conceito de obediência na relação pais e filhos. São Paulo, Paulinas. 
resultados da pesquisa de Caetano (2008), uma vez que devido o grande número de categorias encontradas para cada uma das perguntas da pesquisa, e a distribuição homogênea das respostas dos participantes sobre as mesmas categorias, pode-se inferir a incerteza e a crise pela qual passam os progenitores, inseguros e angustiados a respeito de como educar os seus filhos.

Uma vez que se pôde constatar essa crise no início do processo educativo da criança, ou seja, a dificuldade de pais e mães de apresentarem para os seus filhos o mundo das regras, também intitulado de gênese da moral, o que se pode afirmar a respeito da participação dos pais no desenvolvimento moral da adolescência? A temática da crise na adolescência, já é tipicamente reconhecida, enquanto fase de conflito e rebelião na relação com os pais, entretanto, parece que a dificuldade da educação dos filhos, pode ser tratada também, em termos de outro tipo de crise: a crise da autoridade daqueles que trazem os filhos ao mundo.

Arendt $^{3}(1954 / 2005)$ ao estudar a crise da esfera política na modernidade, argumenta que esse período e suas transformações implantaram uma crise e mal-estar no mundo todo, e tal situação se manifesta de diversos modos, sendo a crise da educação um deles. Ao abordar o tema da crise da educação, constrói reflexões acerca da dificuldade dos pais em assumirem a responsabilidade pela educação dos seus filhos e tais argumentos são aqui apresentados para fundamentar culturalmente, historicamente e filosoficamente a questão da crise da educação, apontada também em uma abordagem psicológica por Winnicott, conforme descrito acima, como "as formas modernas de educar" que interferem diretamente no desenvolvimento do adolescente. Esses mesmos argumentos também dialogam com os problemas da educação moral apontados por La Taille (1996), ao discorrer a respeito da dificuldade da educação moral na relação pais e filhos, contribuições essas que serão apresentadas nos parágrafos posteriores.

Os pais, segundo Arendt (1954/2005), assumem na educação dos seus filhos a responsabilidade ao mesmo tempo pela vida e desenvolvimento da criança, e pela continuidade do mundo. A autora afirma que a criança é um novo habitante do mundo e não conhece nada sobre ele, e que, portanto, necessita ser introduzida nele aos poucos. Conforme as suas próprias palavras:

\footnotetext{
${ }^{3}$ Hannah Arendt (1906- 1975), filósofa e pensadora política foi aluna de Heidegger, Husserl e Jaspers. Construiu uma obra considerável e reconhecida sobre a prática e teoria política de nosso tempo, na qual a filosofia subjaz toda a sua produção. Segundo a autora a modernidade implantou uma crise e mal-estar no mundo todo, e tal situação se manifesta de diversos modos, sendo a crise da educação um deles. Esse último tema é abordado nesse trabalho, ao se apresentar os argumentos da autora para fundamentar a questão da crise da educação, tão disseminada pelas abordagens de senso comum.
} 
Os pais humanos, contudo, não apenas trouxeram seus filhos à vida mediante a concepção e o nascimento, mas simultaneamente os introduziram em um mundo.[...] A criança requer cuidado e proteção especiais para que nada de destrutivo lhe aconteça de parte do mundo. Porém também o mundo necessita de proteção, para que não seja derrubado sobre ele a cada nova geração. (Arendt,1954/2005, p. 235).

Para a autora tais responsabilidades são conflituosas e não coincidentes, e, portanto, é grande a dificuldade dos pais para cumpri-las. Para ela, assumir a responsabilidade pela vida da criança implica em cuidar dela enquanto está se desenvolvendo, ou seja, em não abandonála por si só no mundo, ou melhor, protegê-la, pois não está preparada para a convivência no espaço público. Necessita do recôndito do espaço privado, onde pelo contrário, estará protegida do mundo.

Ao conceituar o espaço público e o privado no livro "A condição humana” (1958/2007, p.39), utilizando a estrutura de organização social da polis da Grécia clássica, a autora explica que é no espaço privado, ou seja, na esfera familiar que os homens vivem juntos, compelidos por suas necessidades e carências. Por outro lado, o que caracteriza o espaço público é a liberdade, alcançada por aqueles que podem pensar, expressar-se e conviver livre das imposições alheias. Nas palavras da autora (1958/2007, p.41): "Ser livre significava ao mesmo tempo não estar sujeito às necessidades da vida nem ao comando do outro e também não comandar."

Conforme os argumentos de Arendt, uma das características da modernidade é exatamente a decrescente diferenciação das esferas pública e privada: o que se presencia nos tempos atuais é uma rejeição à distinção entre o que é do âmbito público e o que é do privado, pois uma esfera social transforma em público o que é privado e o resultado é que "a administração doméstica e todas as questões antes pertinentes à esfera privada da família, inclusive a educação das crianças, transformam-se em interesse coletivo". (Arendt, 1958/2007, p.42).

O grande problema dessa situação está no fato de que a criança dessa família coletivizada fica exposta ao público, sendo que não estaria pronta para esse encontro. Segundo a autora, isso torna as coisas mais difíceis, pois as crianças pedem, por natureza "a segurança do ocultamento para que não haja distúrbios em seu amadurecimento". (Arendt, 1954/2005, p.238).

A coerência do argumento de Arendt se sustenta na hipótese de que, apenas a partir da modernidade se passou a considerar a natureza específica da criança e do adolescente, sendo que, para ela é contraditório que as mais elementares condições de vida necessárias ao 
crescimento e ao desenvolvimento da criança sejam negligenciadas, na medida em que a educação moderna acaba excluindo a criança do mundo adulto, sob o pretexto de respeitar a independência da mesma, e dessa forma, lhe abandona na vivência de um mundo infantil. Os pais ao abdicarem da necessidade essencial de proteger as crianças do mundo, até que elas se sintam preparadas para se integrar ao mundo público, retêm a criança em um mundo infantilizado, e conforme as palavras da autora:

Essa retenção da criança é artificial porque extingue o relacionamento natural entre adultos e crianças, o qual, entre outras coisas, consiste do ensino e da aprendizagem, e porque oculta ao mesmo tempo o fato de que a criança é um ser humano em desenvolvimento, de que a infância é uma etapa temporária, uma preparação para a condição adulta. (Arendt, 1954/2005, p.233)

Aqui se apresenta a segunda parte da responsabilidade da educação dos pais, ou seja, a continuidade do mundo, pois a preparação das crianças para a condição adulta é parte de um processo de proteção do mundo. Segundo a autora, a educação humana tem essa dupla função de formar o ser humano que é a criança, que não se acha acabada, mas em estado de vir a ser e, formar um ser humano novo, ou seja, responsabilizar-se pelo novo que irrompe sobre o mundo a cada nova geração. A autora afirma: "Porém também o mundo necessita de proteção, para que não seja derrubado ou destruído pelo assédio do novo que irrompe sobre ele a cada nova geração". (Arendt, 1954/2005, p.235).

Essa afirmação de Arendt é extremamente interessante, no sentido de que, normalmente, quando se discute a educação das crianças e adolescentes, esse âmbito do reflexo da herança dessa educação para o mundo é subjugado, ou no máximo, tal discussão é efetivada por meio de jargões que parecem ter perdido o sentido na sociedade moderna, como afirmar que as crianças e jovens de hoje são o futuro da nação ou do planeta.

Todavia, os pais de fato têm uma responsabilidade para com o mundo. Winnicott (1986/2005), em se remetendo ao desenvolvimento do adolescente, apresenta uma das características que para ele é essencial ao adolescente - a imaturidade. $\mathrm{O}$ autor reflete sobre a importância de compreender essa fase do desenvolvimento humano com uma perspectiva mais ampla que somente as questões pertinentes a cada indivíduo ou família, convidando a compreensão da adolescência como uma fase muito especial do desenvolvimento, exatamente por se tratar da fase da imaturidade:

A imaturidade é uma parte preciosa da adolescência. Ela contêm as características mais fascinantes do pensamento criativo, sentimentos novos e desconhecidos, idéias 
para um modo de vida diferente. A sociedade precisa ser chacoalhada pelas aspirações de seus membros não-responsáveis. (Winnicott,1986/2005, p.158).

Da mesma forma, Sayão (2003) também chama a atenção dos genitores e educadores para a necessidade da revisão do modo de olhar para os adolescentes, apenas como sujeitos problemáticos e fonte inerente de conflitos. A autora sugere que tais adultos se atentem para essa outra possibilidade que está implícita no potencial cognitivo e social do jovem. Conforme suas próprias palavras:

Como os adultos que convivem com os adolescentes e têm com eles uma responsabilidade educativa podem mudar seu olhar para, assim, mudar o modo de tratar as situações que eles trazem? Primeiro, é preciso reconhecer que eles são a esperança de mudanças que nós não conseguimos - nem vamos mais conseguir realizar por um motivo ou por outro. (Sayão, 2003, p.112).

Amparar o jovem para que ele se desenvolva plenamente e possa trazer algo novo à sociedade é o papel dos adultos que precisam se reconhecer com tal responsabilidade, bem como reconhecer a imaturidade como característica positiva da adolescência.

Arendt afirma na sua reflexão sobre a dupla função de educar a criança para preservar o mundo, que a crise no processo da educação é em grande parte fruto da negação da autoridade por parte dos adultos: "na educação, essa responsabilidade pelo mundo assume a forma de autoridade". Segundo ela, a autoridade dos pais ou dos professores, assenta-se na responsabilidade que os mesmos assumem por este mundo, e as circunstâncias revelam que também a autoridade está em crise.

Conforme as reflexões da autora, na vida pública e política a autoridade não representa mais nada, e mesmo nos países totalitários, nos quais a violência e o terror representam exatamente a desfiguração da autoridade, o papel dela tem sido altamente contestado. Arendt afirma que:

Isso, contudo, simplesmente significa, em essência, que as pessoas não querem mais exigir ou confiar a ninguém o ato de assumir a responsabilidade por tudo o mais, pois sempre que a autoridade legítima existiu ela esteve associada com a responsabilidade pelo curso das coisas do mundo. [...] As exigências do mundo e seus reclamos de ordem estão sendo consciente ou inconscientemente repudiados; toda e qualquer responsabilidade pelo mundo está sendo rejeitada, seja a responsabilidade de dar ordens, seja a de obedecê-las. (Arendt, 1954/2005, p.240).

Segundo Arendt a demonstração da insatisfação das pessoas diante das mudanças históricas e da condição política, que impôs a modernidade: desconfiança geral que a 
modernidade lançou sobre as pessoas, especialmente, a dificuldade na perda da autoridade da vida política, a sobreposição da vida privada a vida pública causada pela prevalência do social, traduziu-se pela recusa por parte do homem moderno da responsabilidade perante o mundo, que constitui a educação das crianças:

É como se os pais dissessem todos os dias: - Nesse mundo, mesmo nós não estamos muito a salvo em casa; como se movimentar nele, o que saber, quais as habilidades dominar, tudo isso também são mistérios para nós. Vocês devem tentar entender isso do jeito que puderem; em todo caso, vocês não têm o direito de exigir satisfações. Somos inocentes, lavamos as nossas mãos por vocês. (Arendt, 1954/2005, p.242)

Dessa forma os pais abdicam do seu papel de autoridade na vida privada. Porém a autora afirma que, quando os adultos recusam a autoridade, recusam-se também a assumir a responsabilidade pelo mundo ao qual trouxeram as crianças.

As idéias da autora alertam para a responsabilidade que o processo educativo irrompe. Muitos pais especialmente no período da adolescência caem no ledo engano de acreditar que os seus filhos já estão prontos, educados e aptos para prosseguirem sozinhos. Sayão, também discute a crise que a ausência da autoridade no mundo moderno provoca no adulto que educa:

Importante é lembrar que, para impor limites, é preciso exercer autoridade. Desde o início do mundo moderno, vivemos a crise da autoridade, e não foi a escola - muito menos a família - que a originou. Ao contrário: pais e professores arcam com o fato. Assumir a autoridade sendo mãe, pai ou professor, portanto, não tem sido nada fácil. (Sayão, 2003, p. 51).

La Taille (1996, p.175), discutindo a dimensão educacional da construção dos limites, das regras, ou seja, do papel da autoridade diante da temática da educação moral, afirma que o “desequilíbrio na convivência entre pais e filhos", se justifica por uma inversão de valores, de forma que os adultos se adaptam ao mundo adolescente e infantil e não esses últimos aos primeiros, ou seja, a sociedade pode ser atualmente denominada puericêntrica.

Esse primeiro problema se amplia quando esse adolescente acostumado à liberdade e ao espaço que possui na casa dos pais, não busca se libertar do mundo das regras do adulto, pois na verdade esse mundo ficou infantilizado. Para eles, o sair de casa significa perder a liberdade e não alcançá-la. Assim tais jovens não se incorporam no meio do trabalho e nem conseguem formar unidade familiar própria. Toda essa questão é ainda reforçada pelas dificuldades financeiras, sociais e econômicas do mundo atual, que acabam reforçando concretamente essa realidade psicológica.

Conforme as palavras de De Souza (2000, p.37): 
Há adolescentes que se acomodam a esse status quo infantilizado e não buscam superar as dificuldades. Em todos os casos, isso dificultará o desenvolvimento de uma nova identidade, fundamental para o desenvolvimento da personalidade nessa fase. (...) Os consultórios de psicoterapeutas recebem com muita freqüência pacientes jovens, os quais necessitam menos de tratamento do que suas famílias, as quais não se adaptam ao novo status de seus filhos.

Outro problema apontado por La Taille (1996, p.176) diz respeito ao crescente permissionismo que conduz as intervenções parentais de modo que a criança habitua-se a ter os seus desejos satisfeitos desde muito cedo, com isso não constrói a capacidade de lidar com as perdas, as frustrações, bem como, impede as mesmas de construírem o chamado "sentimento de obrigatoriedade que nasce das relações que Piaget chamou de coação", ou seja, da exterioridade das regras transmitidas pelos adultos, em certo momento do desenvolvimento moral do sujeito.

Retomando a experiência da psicóloga Sayão, podemos legitimar essa dificuldade especialmente vivida por pais de adolescentes:

Pois é. Muitos pais de adolescentes cometeram e ainda cometem este engano: o de achar que o filho dessa idade pode ter a responsabilidade de decidir sozinho como viver, aonde ir, até que horas ficar, o que fazer e o que não fazer. E, em geral, esses pais dizem que confiam nos filhos e na educação que deram a eles até então. [...] Para aprender a viver sozinhos, os adolescentes precisam saber que não estão sozinhos, que continuam sendo amados, até mesmo quando começam a divergir dos pais. (Sayão, 2003, p.111)

A questão é que os pais de hoje vivem esse grande conflito de não saber exatamente por quais limites, valores, e ideais pautarem as suas intervenções educativas. Não sabem mais o que querem para os filhos. La Taille (1996), afirma que a moral humana tem que ser pensada em função da sociedade como um todo e a vivência atual da modernidade, ou até mesmo, a pós-modernidade, é a conservação de quase nada: a tecnologia transforma com rapidez os objetos mais modernos em sucatas. A educação moral é prejudicada pela dificuldade dos progenitores em argumentarem com seus filhos sobre aquilo que consideram como bom, correto e moral, pois não sabem sobre esses princípios sequer para si mesmos. (La Taille, 1996, p.177).

Segundo Sayão (2003, p. 99), a dificuldade que os pais apontam por titubearem em formar pessoas justas, respeitosas, solidárias, não-consumistas, alegando que se seus filhos forem assim, não sobreviverão nos dias de hoje, tem dois motivos principais. O primeiro diz 
respeito à idéia cada vez mais divulgada de que a felicidade implica em aceitação social e o segundo, que completa o primeiro, diz respeito à tendência dos pais de "educar os filhos para que eles tenham as melhores chances de vencer na vida".

A sociedade atual, segundo La Taille (2009, p. 171), valoriza os vencedores e despreza os "perdedores", sendo que o "vencedor", não é aquele que alcançou uma boa posição social, ou um bom trabalho, mas é aquele que, além de se dar bem na vida, se "deu melhor do que os outros", inclusive, não é exagerado dizer que os vencedores são reconhecidos por determinadas "marcas" (de carro, de roupas, de jóias, etc, ou, o bairro onde se vive, o restaurante que se freqüenta) que tornam visíveis o seu sucesso para os outros, e portanto, vale tudo para ser vencedor, inclusive, por exemplo, "atropelar" profissionalmente o outro, para ter uma carreira meteórica.

Em resumo, embora mais liberal a respeito de atitudes e traços de personalidade, a sociedade atual sobrevaloriza os chamados "vencedores" e tende a comprometer seriamente a autoestima de todos aqueles que não conseguem tal lugar de destaque. Logo, muitos tendem a sonhar em ser "vencedores" e/ou "educar" seus filhos para que o sejam. (La Taille, 2009, p. 173).

Obviamente que, para esses pais e mães que estão educando os seus filhos para serem "vencedores", educar implica em valorizar bens, comportamentos, equipamentos, aparências, fama, carros luxuosos, roupas de grifes, entre outros exemplos. Sendo essa a hierarquia de valores dos pais, ensinarão aos filhos competências necessárias para alcançar esses valores, e certamente, nesse currículo, não entrarão virtudes como dignidade, respeito, justiça e solidariedade.

A importância da família para essa fase do desenvolvimento do adolescente também é discutida por Winnicott (1965/2001), que relata a importância primordial das formas de interação com o ambiente para o desenvolvimento humano, reforçando a necessidade do reconhecimento por parte dos adultos da sua função como pais de adolescentes. Conforme suas próprias palavras:

Muitas das dificuldades por que passam os adolescentes, e que muitas vezes requerem a intervenção profissional, derivam das más condições ambientais; este fato apenas serve para enfatizar a vital importância do ambiente e da família para aquela imensa maioria de adolescentes que de fato chega à maturidade adulta, mesmo se, para os pais, o processo todo é pontilhado de dores de cabeça. $(1965 / 2001$, p. 117)

Portanto, essa pesquisa busca compreender os conceitos dos adultos em relação à constituição da autonomia moral de seus filhos. A relevância do estudo das concepções dos 
adultos legitima-se primeiramente na necessidade explícita da educação moral das crianças, conforme os resultados da pesquisa de Caetano (2008, p. 183) demonstraram, indicando que os pais e mães entrevistados desconhecem as fases do desenvolvimento moral e por isso, têm dificuldades tanto em definir os seus objetivos ao educar, quanto em fazê-los valer ao escolherem as intervenções concretas junto aos filhos.

Em segundo lugar, quanto aos adolescentes à temática da educação moral, também se apresenta como um estudo relevante e necessário, uma vez que as pesquisas com adolescentes têm focado na participação dos pares e das instituições sociais na formação moral do jovem, enquanto que o papel da família tem sido relativamente negligenciado pelas mesmas. (Smetana, 1999, p. 311).

E, finalmente, investigar a educação moral no domínio dos pais e filhos adolescentes, é uma opção que tem a ambição de oferecer a sociedade brasileira uma análise das concepções educativas dos pais e mães de adolescentes, o que permitirá a reflexão e quem sabe a modificação de atitudes, na perspectiva de atender ao convite feito por Arendt (1964/05, p.247):

A educação é o ponto onde decidimos se amamos o mundo o bastante para assumirmos a responsabilidade por ele e, com tal gesto, salvá-lo da ruína que seria inevitável não fosse a renovação e a vinda dos novos e dos jovens. A educação é, também, onde decidimos se amamos nossas crianças o bastante para não expulsá-las do nosso mundo e abandoná-las aos seus próprios recursos, e tampouco arrancar de suas mãos a oportunidade de empreender alguma coisa nova e imprevista para nós, preparando-as em vez disso com antecedência para a tarefa de renovar um mundo comum. (Arendt, 1964/05, p.247)

Com esse mesmo parágrafo Arendt conclui o seu texto sobre a crise da educação. Utilizando a propriedade das palavras da autora, e pensando no título desse capítulo adolescência e a crise da educação - justifica-se a pertinência dessa pesquisa que se propõe a investigar os conceitos dos adultos (pais, mães e responsáveis) em relação a esta responsabilidade, ou seja, ser cooperativo (no sentido piagetiano) na construção da autonomia moral dos seus filhos. Consecutivamente ser cooperativo com os filhos significa cumprir o papel de "bons pais": protegendo seus filhos do mundo, até que se tornem adultos, e protegendo o mundo de seus filhos, arcando com a responsabilidade do seu papel de educadores. 


\title{
2- ADOLESCÊNCIA: CONCEITOS, TEORIAS e PESQUISAS
}

\begin{abstract}
Vejo os jovens buscando um tipo de identificação que não os abandona sozinhos em sua luta: a luta para sentir-se real, a luta para estabelecer uma identidade pessoal, a luta para viver o que deve ser vivido, sem ter medo de conformar-se a um papel preestabelecido. Os adolescentes não sabem o que se tornarão. Não sabem onde estão, e estão a esperar. Tudo está suspenso; isso acarreta o sentimento de irrealidade e a necessidade de tomar atitudes que lhes pareçam reais, e que de fato são, na medida que afetam a sociedade. (Donald W. Winnicott, 1965/2001)
\end{abstract}

A fase da adolescência é considerada pelo senso comum como um período de riscos e aborrecimentos, principalmente para os pais. O "deixar ir" anunciado pela chegada da fase de desenvolvimento que antecede e prepara para o ingresso no mundo adulto, trata-se de um momento sempre difícil para a família, envolvendo muitos conflitos e temores: drogas, bebidas, sexualidade, namoros, amigos, saídas noturnas, gravidez precoce, vida social, carros, estudos, sucesso profissional...

Muitos estereótipos são criados e sustentados em relação a essa fase do desenvolvimento humano, apontada por algumas teorias como um momento crítico, no qual o relacionamento com os pais se torna caótico, tendo o jovem à tendência a desobediência e ao isolamento, aos comportamentos anti-sociais e a agressividade. Há inclusive uma forma pejorativa muito divulgada e comumente utilizada ao se referir aos jovens da faixa etária de doze aos dezoito anos aproximadamente, intitulados de "aborrecentes". Mas o que de fato é a adolescência? Como conceituá-la?

Segundo Palácios e Oliva (2004, p.309): "Por adolescência costumamos entender a etapa que se estende, grosso modo, desde os doze ou treze anos até aproximadamente os vinte anos de idade. É uma etapa de transição em que já não se é criança, mas ainda não se tem o status de adulto". Todavia a adolescência é um fenômeno recente, cujo significado, desenvolvido pelo mundo ocidental, é subjacente a um dado contexto histórico-social e econômico.

Para que se possa compreender a afirmação do parágrafo acima, é necessário fazer a distinção entre dois conceitos importantes, e muitas vezes utilizados de forma equivocada: puberdade e adolescência.

Chamamos puberdade ao conjunto de mudanças físicas que ao longo da segunda década de vida transformam o corpo infantil em um corpo adulto capacitado para a reprodução. Chamamos de adolescência a um período psicossociológico que se 
prolonga por vários anos mais e se caracteriza pela transição entre a infância e a idade adulta. (Palácios e Oliva, 2004, p.311).

Portanto, a puberdade é um fenômeno universal e, também, pode-se dizer, filogenético, ou seja, algo vivenciado por todos os representantes da espécie humana. Com relação a adolescência, não pode ser assim considerada, uma vez que se trata de um fenômeno considerado bastante recente, próprio da civilização ocidental, isto é, um fato psicossociológico, cujas características, tal qual se conhece, foi sendo delineada ao longo do século XX.

O historiador Ariès (1973/2006, p.115), apesar de pouco escrever a cerca dessa fase de desenvolvimento, afirma que a adolescência e a infância sempre foram confundidas, porque o adolescente era separado do mundo adulto, dentro do ambiente escolar, mas considerado como criança. Ele ainda afirma que a discriminação entre infância e adolescência só foi distinguida progressivamente e tardiamente a partir do século XIX, conforme a necessidade de uma pedagogia nova, que entre outras medidas, propôs a correspondência cada vez mais rigorosa entre a idade e a composição das classes nas escolas. "Sem o colégio e suas células vivas, a burguesia não dispensaria às diferenças mínimas de idade de suas crianças a atenção que lhes demonstra, e partilharia nesse ponto da relativa indiferença das sociedades populares." (Áries, 1973/2006, p.115).

A partir dos estudos de Ariès sobre a "História Social da Criança e da Família", bem se sabe que os sentimentos de infância, enquanto uma fase do desenvolvimento humano com toda a sua especificidade, é um fenômeno recente, e que é portanto, sincrônico com a constituição da burguesia moderna. Dessa forma, não é de se estranhar que a idéia da adolescência seja essencialmente ocidental, e, ainda mais tardia, uma vez que, "até o final do século XIX, as crianças se incorporavam ao mundo do trabalho entre os sete anos e o começo da puberdade". (Palácios e Oliva, 2004, p.310).

Não se pode negar, tão pouco, a grande influência do conceito de família, que se observou nesse processo da constituição do fenômeno da adolescência. Segundo Grossman (2004, p. 70), na transição da idade média para a modernidade, a relação entre pais e filhos sofreu modificações, ou seja, na verdade, o fortalecimento do espaço privado providenciou um novo significado da família, que superou o conceito de uma unidade simplesmente econômica, transformando-se em uma unidade afetiva na qual se estabeleciam relações de sentimento entre o casal e os filhos, gerando a necessidade de atenção e cuidados diferenciados para com a criança, especialmente, no que diz respeito a sua necessidade de 
proteção das tentações da vida. Portanto, juntamente com as escolas e a igreja, as famílias tornaram-se espaço para a educação moral.

Entretanto será no século XIX que, com o considerável aumento do número da população e a redefinição do papel da mulher e da criança na sociedade que a infância será reconhecida realmente como uma fase específica do desenvolvimento da pessoa, assim como a relação entre pais e filhos, será novamente reconstruída, sendo que os filhos passarão a representar o futuro da família e por isso, os investimentos neles se amplificarão. Conforme Grossman (2004, p. 71), "neste momento a figura do adolescente é delineada com precisão.[...] A adolescência é temida como uma fase de potenciais riscos para o próprio indivíduo e para a sociedade como um todo. Ela se torna presente como tema dos estudos de médicos e educadores."

A questão é que, com a revolução industrial, o estudo e a formação se tornaram importantes, e desse modo, a inserção do jovem no mundo do trabalho passou a acontecer mais tardiamente, uma vez que as famílias passaram a investir na formação escolar dos mesmos, o que retardou a inserção deles no mundo do trabalho, especialmente, para aqueles oriundos da classe média. Mesmo para os filhos da classe operária esse mesmo proceder acabou sendo incorporado ao estilo de vida, pois a escolaridade obrigatória proporcionada pelo estado, prevê que o adolescente se dedique aos estudos, ao menos até os dezesseis anos. (Palácios e Oliva, 2004, p.310).

Atualmente, esse permanecer sobre a custódia dos pais tem se ampliado cada vez mais. Diferentemente do que se observava há décadas atrás, quando o grande objetivo da adolescência, era fazer a transição entre a infância e o mundo adulto, fato que se dava pelo rompimento do vínculo afetivo dos adolescentes com os pais, a conquista do amor, e especialmente a inserção no mundo do trabalho; observa-se atualmente uma nova realidade. Conforme, se discutiu no primeiro capítulo desse texto, a crise na educação tem providenciado uma alteração considerável nessa forma de funcionamento do desenvolvimento humano. Conforme as palavras de Palácios e Oliva (2004, p. 314):

A incorporação dos adolescentes ao status adulto demora cada vez mais, de tal forma que é cada vez mais freqüente nos encontrarmos com pessoas que são física e psicologicamente adultas, mas que, no entanto, não têm um status de adulto: continuam sob a dependência de seus pais, não se incorporam ao mundo do trabalho, não podem formar uma família própria, etc., e não porque não desejam se tornar independentes, [...] mas porque o custo de vida, as condições sociais de dificuldade para entrar no mundo do trabalho e o prolongamento da escolaridade fazem com que seja impossível materializar esses desejos. 
Por outro lado, ao mesmo tempo em que se delineia a ampliação indefinível do percurso e duração da adolescência, sendo que um novo termo inclusive se apresenta: a "adultescência", ou seja, jovens com mais de vinte cinco anos que embora sejam adultos, não têm status de adulto; quando se pensa no jovem dos seus 12 anos (como por exemplo, no Brasil, que já trabalha em subempregos, desde 4 ou 5 anos, vendendo balas nos semáforos), não se pode falar em um menino pré-adolescente. Não pelo menos, nesse conceito de adolescente que caracteriza o jovem ocidental de classe média, e alta, cujas características são: ser estudante, viver com seus pais e deles depender para subsistir, estar em busca da libertação do apego a família e em busca da integração com um grupo de outros jovens, ter preocupações que não são mais da infância e tão pouco são de adultos.

A questão é que não se pode afirmar a existência de uma concepção homogênea do que é adolescência. Segundo Palácios e Oliva (2004, p.314): "Nenhuma das teorias existentes oferece uma explicação definitiva do desenvolvimento desse período, ainda que em cada uma delas possamos encontrar alguma contribuição que nos ajuda a compreendê-la melhor". De Souza (2000, p.35) afirma que a adolescência é considerada pelas teorias clássicas da psicologia como um fenômeno universal, normalmente considerado como um período de turbulências e transformações marcantes de personalidade, de conduta social e de inteligência. Tudo isto devido às mudanças fisiológicas e à entrada no mundo adulto. Conforme as palavras da autora, outras teorias do desenvolvimento psicológico apontam para o fenômeno da adolescência, de forma menos universal e mais ligado ao grupo social onde o jovem está inserido:

As características expressas no comportamento do adolescente seriam uma continuidade das características anteriores do desenvolvimento psicológico individual, não havendo mudança "drástica", mas apenas evolução a partir da evolução anterior. (De Souza, 2000, p.36)

G. Stanley Hall, psicólogo americano, foi considerado o pioneiro a estudar e escrever sobre a adolescência. Em 1904 publicou dois volumes contando com mais de 1400 páginas, intituladas "Adolescense", nas quais apresentou uma obra considerada "monumental", mas apontada por muitos autores contemporâneos como ultrapassada e irrelevante, especialmente pelas dificuldades de organização e estilo. Segundo tal autor, a adolescência corresponde a um período de tempestade e tormenta, sendo ele o primeiro autor, portanto, a proclamar essa fase do desenvolvimento humano, como uma fase reconhecidamente difícil. 
Hall (1903) afirmava a importância do período da adolescência, pois, segundo ele, seria nesse momento que o ser humano poderia ser educado. Segundo Gallatin (1942/1978, p.27), entre as contribuições de Hall, uma delas foi justamente assinalar a necessidade de expor os princípios que governam o crescimento humano e o fato do autor mostrar-se precocemente assertivo ao associar a adolescência ao desenvolvimento da individualidade.

Influenciado pelas idéias de Darwin optou pela hereditariedade como prevalescente no debate entre empirismo e apriorismo, e acreditando que o desenvolvimento humano é ordenado pela natureza, criou a teoria da recapitulação, cujo pressuposto fundamental é de que cada fase do desenvolvimento de uma pessoa é uma recapitulação com breves atualizações de estágios anteriores da espécie humana. Portanto, a adolescência é ressaltada pelo autor como vital para a sociedade uma vez que "representa a recapitulação de um estágio da história humana, intermediário entre o primitivo e o civilizado" (Gallatin, 1942/1978, p. 31), um período vital para o sustento do progresso da humanidade.

Conforme as palavras de Hall: “A adolescência é, portanto, a infância de um homem de natureza superior, quando ele recebe da grande mãe-natureza um último capital de energia e de momento evolutivo”. (Hall, 1904, II, p.71, citado por Gallatin, 1942/1978, p. 31).

O pioneiro Hall, embora tão criticado, pela inadequação da teoria da recapitulação, entre outros aspectos já abordados, foi o primeiro a descrever a adolescência como um período crítico do desenvolvimento humano. A tormenta e a tempestade que caracterizam a adolescência foram abordadas pelo autor ao se remeter aos comportamentos extremos e imprevisíveis dos jovens dessa idade. Tal idéia se explicita nas suas palavras: "As forças do pecado e as da virtude nunca lutaram tão ardentemente pela posse da alma do jovem." (Hall, 1904, II, p.83, citado por Gallatin, 1942/1978, p. 37).

A psicanálise também retratou a adolescência como um período turbulento e contraditório. A idéia de que essa fase se caracterizava pela tempestade e pela tormenta, também pode ser ilustrada perfeitamente pelas palavras da autora Anna Freud (1936/1986) que, relatou as incríveis mudanças características desses anos, “as perturbações no equilíbrio psíquico e, sobretudo, as incompreensíveis e irreconciliáveis contradições então evidentes na vida psíquica" (1936/86, p.117). Conforme se pode ilustrar pela citação abaixo descrita, Anna Freud, também fez uma análise da complexidade da fase da adolescência, reforçando o caráter negativo de uma fase do desenvolvimento carregada pela passionalidade, pela contradição e pelo conflito: 
Os adolescentes são excessivamente egoístas, considerando-se o centro do universo e o único objeto de interesse e, entretanto, em tempo algum de sua vida ulterior são capazes de tanta abnegação e dedicação. Formam as mais apaixonadas relações de amor, para rompê-las tão abruptamente quanto as iniciaram. Por um lado, atiram-se entusiasticamente à fruição da vida da comunidade e, por outro lado, possuem uma irresistível ânsia de solidão. Oscilam entre cega submissão a um líder autoeleito e a rebelião insolente contra toda e qualquer autoridade. São egoístas e materialistas mas, ao mesmo tempo, cheios de um idealismo grandioso. São ascéticos mas, subitamente, mergulharão na indulgência instintiva do mais primitivo caráter. Por vezes, seu comportamento em relação a outras pessoas é turbulento e irrefletido; contudo, são extremamente sensíveis. Seus estados de espírito variam entre o otimismo leviano e o mais sombrio pessimismo. Algumas vezes, dedicam-se ao trabalho com infatigável entusiasmo e, outras vezes, são preguiçosos, desleixados e apáticos. (Anna Freud,1936/86, p.118)

Como se pode observar pela descrição anterior, não há discórdia entre Anna Freud e Hall no que se refere à descrição da adolescência. Ambos os autores terão vários pontos em comum: intenso romantismo atribuído a tal fase, a caracterização do período como contraditório, tempestuoso e atormentado pelos extremos do bem e do mal. O que difere entre os autores é a interpretação de toda essa lendária tormenta. A recapitulação é reconhecida por Anna Freud, mas em um contexto diferente da idéia de recapitulação de Hall (1904). Para a autora, a adolescência não é resultado de uma fase de transição na história humana, período de indefinição este que, provocaria toda a turbulência característica da adolescência; mas o motivo de toda essa tempestade e tormenta é o retorno dos conflitos da sexualidade infantil, especialmente o Complexo de Édipo ${ }^{4}$ que retorna com força total.

Anna Freud (1936/86, p.118) admite que a psicanálise pouco tenha se concentrado nos problemas da adolescência, por uma razão que ela mesma aponta como óbvia, isto é, para a psicanálise a vida sexual não começa na puberdade, mas nos primeiros anos de vida, nos quais se registram os passos cruciais do desenvolvimento sexual. A puberdade, entendida como uma das fases do desenvolvimento da vida humana é apontada como a primeira fase na qual ocorre a primeira recapitulação do período sexual infantil, sendo a segunda, o climatério. Desse modo a autora definirá esse período estabelecendo as relações entre id e ego, ou seja, as mudanças fisiológicas e hormonais da puberdade se constituem em um reforçador do id (sede

\footnotetext{
${ }^{4} \mathrm{O}$ complexo de Édipo se instaura na fase do desenvolvimento psicológico infantil, chamado por Freud de fase fálica, ou seja, a fase em que a libido inicia nova organização, isto é, dá-se a passagem da erotização anal para a genital. Daí a participação da figura materna e paterna para a constituição da interiorização das normas e condutas. Até a fase anterior, os valores e limites eram externos, entretanto, quando o menino "se apaixona" pela mãe, mas vê impossibilitada a realização da sua fantasia pela presença do pai, "dono" da mãe e poderoso para recompensar e punir,vivencia a repressão da sexualidade, o que lhe providencia a instauração de um referencial interno de normas. (Fiori, 1981, p.25)
} 
dos instintos), e o ego se vê fragilizado e ameaçado. Daí os conflitos endo-psíquicos tão conhecidos nesse período do desenvolvimento humano.

Observa-se que a psicanálise parece abordar mais especificadamente o caráter universal dessa fase do desenvolvimento humano, e, portanto, pode-se observar inclusive a partir do próprio título do estudo de Anna Freud utilizado para refletir sobre esse tema, "O ego e o Id na puberdade" (1936/86, p.117), que a autora estaria falando desse processo próprio de todo ser humano, no qual a maturidade física sexual que é alçada por todo e qualquer jovem, independente da cultura em que está inserido, processo esse biológico, mas que desencadeará mudanças na esfera psíquíca do sujeito. Portanto, pode-se afirmar certamente que a teoria psicanalítica de Anna Freud se encarregou muito mais da análise psicológica da puberdade, que da adolescência.

A ree-dição do Complexo de Édipo, a que se faz menção nos parágrafos anteriores, ou seja, a recapitulação da vida sexual infantil é marcada pela turbulência, pois exige que o jovem refaça sua escolha objetal, o que implica em um caminho para o desenvolvimento psicológico que pressupõe a continuidade com o desenvolvimento sexual, sendo a fase genital a superar a fase da latência, ou seja, o jovem revive a escolha edípica (fase da latência), mas deve superá-la, desligando-se definitivamente desse seu primeiro objeto de amor (pai ou mãe) na conquista de um novo objeto.

A questão da desvinculação na relação dos adolescentes com seus pais também se encontra nos estudos de Winnicott (1986/2005, p.153), que afirma que "crescer significa tomar o lugar dos pais". Tal autor apresenta a idéia de que existe um processo de morte e assassinato no desenvolvimento do adolescente, uma vez que o jovem vivencia fantasias inconscientes referentes ao crescimento, que implicam na morte do adulto que é maduro e o controla, para que ele, adolescente, possa viver o seu triunfo pessoal e atingindo a maturidade, adquirir o nível do adulto.

Esse processo realmente é complexo, comenta Winnicott (1986/2005, p.153), porém, segundo ele, os adultos precisam saber disso e tolerar com maturidade o característico e difícil aspecto da imaturidade do adolescente. As suas palavras são enfáticas, no tocante ao papel da família no desenvolvimento do jovem nesse período da adolescência:

Se os adultos abdicam, os adolescentes tornam-se adultos prematuramente, mas através de um processo falso. Um conselho à sociedade, para o bem dos adolescentes e de sua imaturidade: não permitir que eles queimem etapas e adquiram uma falsa maturidade através da transferência de responsabilidades que não são deles, ainda que eles lutem por elas. (Winnicott,1986/2005, p.158). 
Assim como Winnicott e Anna Freud, Blos (1979/1996), outro autor psicanalista, também discute o processo de renúncia aos pais como objeto de amor, dentre os assuntos que aborda sobre adolescência. Considerado um especialista no tema, estudou essa fase do desenvolvimento de forma detalhada, pesquisando especialmente as diferenças de gênero no desenvolvimento do adolescente e compartilhando com o modelo estrutural-pulsional clássico da psicanálise.

Segundo Blos (1979/1996), a adolescência se constitui em um processo cuja tarefa principal é o processo da "segunda individuação", pois a primeira individuação acontece na infância, quando a criança se diferencia de seus pais, enquanto objetos diferenciados de si mesma, para internalizá-los, a partir do complexo de Édipo. O que se passa na adolescência é diferente, conforme suas próprias palavras: "O desligamento do objeto, pela individuação no nível adolescente, não ocorre em relação a objetos externos como era o caso da infância; agora ocorre em relação aos objetos internalizados do início da infância.” (Blos, 1979/1996, p. 273)

De acordo com a teoria desse autor, o processo de separação dos pais e desistência dos mesmos como objetos de amor, e a renúncia dos pais como figuras representativas da autoridade, faz parte do processo de "segunda individuação". Entretanto, segundo ele, a conclusão do processo de individuação deve conduzir a uma mutualidade nas relações pais e filhos, uma vez que, no final da adolescência e no início da vida adulta, os conflitos edipianos diminuem, e a tendência é de se constituírem com os pais relações mais maduras.

Portanto, o tema das relações parentais, sempre foi, e ainda é um tema representativo nos estudos da adolescência, uma vez que, desde as concepções de Hall (1903) a respeito da adolescência, por considerar esse período do desenvolvimento humano, como caracterizado pela tempestade e pela tormenta, apontou de forma exacerbada para o conflito entre o adolescente e os seus genitores. Assim, é comum que ao se mencionar o tema da adolescência, termos como "rebelião dos adolescentes", "conflito de gerações" se agreguem a ele, como características complementares da fase. (Gallatin, 1942/78, p. 157).

As pesquisas psicanalíticas influenciaram de forma muito perspicaz a visão sobre a relação entre o adolescente e a família, enquanto um momento de grandes conflitos, supondo relações de "tempestade e tormenta" entre pais e filhos. Para Anna Freud (1936/1986, p.118), a tendência do jovem é de isolar-se e de abandonar os pais, selecionados outrora na infância como objetos de amor e de prestígio, não somente tratando-os com indiferença, mas passando a alimentar pelos mesmos uma peculiar e violenta antipatia. 
Mesmo para Bloss e Erickson (1968/1976), que não sustentaram essa visão psicanalítica tão ortodoxa, a questão do conflito e da crise com os pais permaneceu descrita em ambas as teorias. Para o segundo, o conceito de crise, reforça a necessidade que o jovem tem de edificar a sua identidade, sendo que, para tanto, há a suposição básica de que a maturidade só pode ser alcançada pelo conflito.

Se um jovem pressentir que o meio tenta privá-lo radicalmente de todas as formas de expressão que lhe permitiram desenvolver e integrar o passo seguinte, ele poderá resistir com o vigor selvático que se encontra nos animais que são forçados, subitamente, a defender a própria vida. Pois, de fato, na selva social da existência humana, não existe sentimento vivencial sem um sentimento de identidade. (Erickson, 1968/1976, p.130).

Bloss, por sua vez aponta para uma possibilidade feliz de resolução do conflito entre as gerações, ou seja, propõe que, passados os momentos de desafios recíprocos para pais e filhos, as duas gerações poderiam elaborar não somente o rompimento, mas a partir do processo de individuação constituído, o jovem poderia efetivar a transição para a vida adulta, e, desse modo retomar a relação com os pais de forma mútua. “A individuação implica em que a pessoa em crescimento assuma cada vez mais responsabilidade sobre o que ela faz e que ela é, ao invés de depositar sua responsabilidade no ombro daqueles sob cuja influência e tutela ele cresceu". (Bloss, 1979/1996, p.101)

Mas, a opinião do autor sobre a questão do conflito entre pais e filhos na adolescência é incisiva: "O conflito de gerações é essencial para o crescimento do self e da civilização. Podemos ter confiança ao dizer que o conflito de gerações é tão antigo quanto as próprias gerações”. (Bloss, 1979/1996, p.13). Para ele o conflito tem uma correlação afetiva e a tensão, a ansiedade e depressão são recíprocas entre pais e filhos. Através dos relatos das vivências dos atendimentos aos seus pacientes adolescentes, o autor afirma que a sincronia dos adultos com os seus filhos é normalmente falha e estranha, no tocante ao seu desenvolvimento, da infância e durante a adolescência.

Eles (os pais) não toleram bem a raiva, a ansiedade e a culpa de seus filhos. A tensão, a falha e o desapontamento, do qual nenhuma criança pode ser poupada, tornam-se prontamente neutralizados por um fluxo constante de estímulo e encorajamento. Pode-se pensar que essa abundância de estima possa durar toda a vida. Mas com frequiência, ocorre exatamente o contrário. Isso é devido ao fato de que, na adolescência um self ilusório, alimentado pelos pais até os anos de latência, é finalmente rejeitado num esforço de uma definição mais adequada do self. (Bloss, 1979/1996, p.15) 
O autor ainda escreve sobre a obsessão de alguns adultos pela juventude. Para ele existe uma necessidade dos adultos de "cabeça jovem" de demonstrar que compreendem as exorbitâncias e rebeldias dos jovens, que é tão compulsiva, quanto à necessidade dos jovens de chamar a atenção do mundo dos adultos. Ao mesmo tempo que essa postura diminui o conflito e a ansiedade, para o autor, diminui também a caracterização do ambiente legítimo de argumentações e contestações que o jovem necessita para a sua maturidade emocional.

A idéia de conflito de gerações, disseminada pela psicanálise tornou-se uma verdade que ainda hoje permeia o senso comum. Segundo Oliva (2004, p.351), essa imagem de explosão de conflitos, da rebelião do adolescente, e da separação emocional em relação aos pais, divulgada pela perspectiva psicanalítica, ainda atemoriza muitos pais, mesmo que a maior parte das pesquisas, divulgue atualmente outra imagem sobre o conflito familiar do período, sendo essa visão mais realista e normalizada.

Conforme Steinberg (2001, p.4), um dos erros que podem ter conduzido a esse tipo de concepção de conflito extremado, diz respeito ao fato de que, os estudos psicanalíticos eram realizados com famílias cujos adolescentes apresentavam desordem de condutas ou eram depressivos, e os resultados de tais observações, eram generalizadas para as demais famílias. Por outro lado, pesquisas (Douvan e Adelson, 1966, citado por Grotevant e Cooper, 1986) provaram que os relacionamentos entre pais e adolescentes acontecem dentro de um padrão de normalidade e que, há uma continuidade e tranqüilidade nesse relacionamento ao longo da infância até a adolescência.

Todavia, segundo Steinberg (2001, p.5), caracterizar a visão de conflito e de tempestade na relação pais e filhos na adolescência como totalmente errada, também não pode ser inteiramente verdadeiro, pois, um consenso há entre a maioria das pesquisas sobre o tema: "há um genuíno incremento nas discussões e bate-boca entre pais e adolescentes nos primeiros anos desse período" (Steinberg e Morris, 2001, p.88).

Ainda se tratando das diferentes formas de compreensão da relação pais e filhos na adolescência, Grotevant e Cooper (1986), realizaram investigações sobre as propostas de exacerbado conflito entre pais e adolescentes e ausência total de problemas entre eles e apresentaram outra perspectiva. Conforme suas palavras:

Até pouco tempo, duas diferentes concepções de relacionamento entre pais e adolescentes dominavam a literatura, uma argumenta que a tarefa da adolescência era tornar-se independente da influência dos pais, enquanto que a outra argumentava que, para muitos adolescentes, a qualidade da relação pais e adolescentes permanecia contínua da infância até a adolescência. A terceira perspectiva, com a qual o nosso modelo é congruente e está agora emergindo no lugar das outras, diz 
que a relação pais e adolescentes é transformada consideravelmente do começo da adolescência até o jovem adulto como uma renegociação entre os pais e os adolescentes. (Grotevant e Cooper, 1986, p. 83).

Para os autores, a primeira concepção, referente à visão psicanalítica e social da relação pais e filhos adolescentes, investigou sempre a questão do poder de controle dos pais sobre os filhos. Quanto à segunda visão, isto é, a inexistência de conflitos e a normalidade e continuidade do desenvolvimento na relação entre pais e adolescentes, foi também questionada devido às insuficiências metodológicas dessas pesquisas. Finalmente, a terceira proposta, considerou o conflito, como a continuidade do desenvolvimento, mas, principalmente investigou a transformação que permeava a relação pais e adolescentes. (Grotevant e Cooper, 1986, p.84).

Conforme os estudos de Grotevant e Cooper (1986, p.82), os esforços das pesquisas em sociologia da família, psiquiatria, terapia familiar e desenvolvimento psicológico convergiram para o estudo do papel da família como um contexto para o desenvolvimento individual. Tais autores propõem um novo modelo de conceito de individuação, amparados pela teoria clínica, especialmente pelos conceitos de individuação de Bloss (1979/1996), no qual distinguem "dois fatores que operacionalizam a individuação: a identidade que é refletida no conceito de auto-afirmação (self-assertion) e separação, e a conexão da mutualidade e permeabilidade" (Grotevant \& Cooper, 1986).

As concepções teóricas apresentadas anteriormente, fazem parte da abordagem teórica psicanalítica. Essa não é a opção teórica dessa pesquisa. As considerações dessas pesquisas sobre o tema da adolescência e da relação pais e filhos, são aqui apresentadas, por se constituírem as primeiras pesquisas a respeito do tema, e por representarem portanto, grande importância nos estudos sobre adolescência, conforme se pode observar nos artigos de revisão bibliográfica sobre o tema, conforme, por exemplo a revisão de Petersen (1988).

Segundo o artigo de Petersen (1988) - no qual delineou uma revisão teórica sobre as pesquisas e estudos sobre adolescência - a tendência das pesquisas sobre a temática da adolescência (a partir da década de 80) reflete uma ênfase na investigação do efeito dos contextos nessa fase do desenvolvimento. Tais pesquisas sobre o relacionamento do adolescente com sua família, considerado o contexto mais importante e também o mais pesquisado para o desenvolvimento da adolescência, também caminham nessa direção, de examinar o efeito recíproco da família no desenvolvimento do indivíduo (Cooper e Grotevant, 1986) e do desenvolvimento individual no processo familiar. (Silverberg e Steinberg, 1987). 
Dentro dos temas de pesquisa inerentes a esse processo de investigação do contexto familiar como espaço para a socialização e desenvolvimento do indivíduo, um dos mais importantes, sempre foi exatamente a questão do papel das interações familiares para o sucesso desse desenvolvimento e para a possibilidade de que, a educação, intervenção ou interação familiar tivesse como resultado a formação de pessoas íntegras, ou seja, que os novos adultos, recém-chegados ao mundo, pudessem oferecer a ele, uma espécie de positiva renovação.

Segundo Pettersen (1988, p.584), o seu artigo foi o primeiro devotado inteiramente ao tema da adolescência, ainda que tenha se notado um incremento nas pesquisas sobre adolescentes no final da década de 60 e início da década de 70. A autora aponta três áreas que apresentaram grande atividade de pesquisas sobre adolescência: ajustamentos ou distúrbios de comportamento, puberdade e seus efeitos, relação entre adolescentes e família, sendo importante notar que, tais pesquisas sobre o desenvolvimento psicológico do adolescente, sempre contaram com importantes contribuições da biologia, sociologia, antropologia e medicina, e tinham portanto, caráter interdisciplinar.

A autora ainda fez em sua revisão, uma breve recapitulação da história da pesquisa com adolescente, apontando que as obras a respeito do tema, originaram-se no início do século XX (Hall, 1904; Freud, 1958), e enfatizavam a adolescência como um período de tumulto no desenvolvimento humano. Na metade do século, as teorias (Piaget, 1958; Erickson, 1968; Mead (1953) começaram a integrar aspectos mais positivos no desenvolvimento do adolescente, sendo que a visão dessa fase fica integrada em outras fases do desenvolvimento, e abandona-se a idéia generalizada do tumulto. Segundo a autora, as pesquisas mais atuais sobre o tema, voltaram sua atenção para o efeito do contexto (relações interpessoais, ambiente e situações vivenciadas), para a explicação do desenvolvimento. (Pettersen,1988, p.589)

Portanto, para Piaget, a adolescência não é compreendida como um período de tormenta e tempestade, como para Anna Freud e Stanley Hall. Para ele, o período da adolescência se constitui em mais uma fase do desenvolvimento, sendo também um período de relevada importância, por ser a "idade da integração no universo social do adulto" (Piaget, 1970/1976, p.252), que se dará através da construção de um plano de vida, efetivado pelo ingresso do jovem no campo do trabalho.

A conquista da possibilidade de pensar abstratamente sobre as coisas, é apresentada por Piaget (1964/1986, p.62), como uma construção própria da adolescência que vai assegurar ao pensamento e à afetividade um equilíbrio superior ao que existia na infância. "Os 
adolescentes têm seus poderes multiplicados; estes poderes, inicialmente, perturbam a afetividade e o pensamento, mas depois os fortalecem". (1964/1986, p.62).

O autor afirma que o adolescente constrói uma nova forma de pensamento, que ele intitulou pensamento formal, cuja principal característica é a capacidade de construir sistemas e teorias. Para Piaget essa conquista não é fruto de uma reedição de uma conquista da humanidade, ou da própria reedição do Complexo de Édipo, tampouco, trata-se de uma habilidade que naturalmente desperta nesse período de vida do sujeito.

Para o autor:

As estruturas formais não são formas inatas ou apriori do entendimento, e que seriam escritas previamente no sistema nervoso, e nem representações coletivas que existam inteiramente elaboradas fora e acima dos indivíduos, mas formas de equilíbrio que se impõem pouco a pouco ao sistema de intercâmbios entre os indivíduos e o meio físico e ao dos intercâmbios entre os indivíduos. (Piaget, 1970/1976, p.252).

Portanto, para Piaget, existe entre o aspecto biológico e o social algo extremamente precioso que se constitui que é a ação do sujeito. Essa conquista do pensamento formal, é fruto "do conjunto das experiências e dos exercícios feitos pelo indivíduo para adaptar-se simultaneamente ao mundo físico e ao mundo social”. (Piaget, 1970/1976, p.252).

O estágio formal, como é chamado por Piaget, o estágio de desenvolvimento cognitivo que deve ser construído pelo adolescente, é aquele anunciado pela possibilidade de um raciocínio abstrato, onde as hipóteses podem ser testadas, os objetos e juízos combinados de todas as formas possíveis, e as operações são chamadas de formais ou hipotético-dedutivas ${ }^{5}$. As inversões e reciprocidades reúnem-se em um único sistema de transformações, dando origem à combinatória, ao grupo das duas reversibilidades (grupo INRC) e às operações proposicionais. Conforme as palavras de Jean Piaget (1964/1986, p.64): “As operações formais fornecem ao pensamento um novo poder, que consiste em destacá-lo e libertá-lo do real, permitindo-lhe, assim construir, a seu modo, as reflexões e teorias”.

Elkind (1975, p.108) remetendo-se aos estudos de Piaget sobre a estrutura cognitiva do adolescente aponta para três aspectos que diferenciam o pensamento do adolescente do da criança: capacidade do adolescente de lidar com a lógica operatória; capacidade de pensar hipoteticamente; capacidade de construir ideais

Quanto ao primeiro aspecto, ou seja, a capacidade do adolescente de lidar com a lógica

\footnotetext{
${ }^{5}$ As operações formais constituem exclusivamente a estrutura de equilíbrio final, para a qual tendem as operações concretas, quando se refletem em sistemas mais gerais que combinam entre as proposicções que as expressam. (Battro, 1978, p.176).
} 
combinatória, diz respeito a uma amplitude da capacidade de raciocínio que conduz o jovem a uma infinidade de alternativas para solucionar os seus problemas e todos os problemas do mundo, sendo a alternativa diretiva paterna apenas mais uma, porém, imprescindível o é para ele conhecê-la, e principalmente os argumentos e justificativas adjacentes, bem como a comparação da posição dos genitores com suas próprias atitudes e virtudes. Por isso, que muitos pais de adolescentes se queixam de que eles discordam de absolutamente todas as suas ordens e opiniões.

Tal pensamento explica também outra característica típica dessa fase do desenvolvimento - a indecisão dos jovens - pois o trabalho do raciocínio combinatório torna o processo de tomada de decisão um problema. Conforme palavras do autor: "O adolescente exige que seus pais tomem uma decisão, ainda que seja para que ele possa rebelar-se contra a mesma”. (Elkind, 1975, p.109).

$\mathrm{O}$ autor ainda afirma que essa capacidade de pensar ao mesmo tempo sobre muitas e diferentes alternativas, isto é, os aspectos cognitivos do conflito, são em parte responsáveis pelos tumultos e tensões deste período, e daí a necessidade da busca de opiniões divergentes daquelas dos seus pais, encontradas então nas conversas com os amigos.

Em resumo, a presença de estruturas que capacitam o adolescente a construir múltiplas alternativas prepara o terreno para os conflitos característicos entre jovens e pais, assim como para a crescente dependência quanto ao grupo de amigos para a tomada de uma decisão final. (Elkind, 1975, p.109)

O segundo aspecto que diferencia o raciocínio da criança do raciocínio do adolescente, apresentado por Elkind é a capacidade de pensar hipoteticamente, o que garante aos adolescentes a possibilidade de pensar sobre o próprio pensamento. Daí a característica da introspecção dos jovens, que explica as horas que passam deitados em seus quartos olhando para o teto.

Por último, o terceiro aspecto que caracteriza o pensamento do adolescente, segundo Elkind, é a capacidade de construir ideais, ou situações contrárias à realidade. Conforme as palavras do autor:

Muito da rebelião adolescente contra a sociedade adulta origina-se, pelo menos em parte, dessa nova capacidade de construir situações ideais. Entretanto, esses ideais são quase que inteiramente intelectuais e o jovem tem pouca noção de como poderiam ser transformados em realidade, e menos ainda tem interesse em trabalhar para concretizá-los. (1975, p.111) 
O conhecimento das estruturas do pensamento do adolescente auxilia na compreensão dos muitos conflitos que vivenciam com a sua família. Os pais que até então cumpriam o papel de ego ideal são criticados com voracidade pelos jovens, que passam a acreditar que o "[...] simples fato dos ideais poderem ser concebidos significa que podem ser facilmente concretizados sem qualquer sacrifício". (Elkind, 1975, p.111)

Piaget afirma que a estrutura de pensamento formal ocasiona no adolescente a vivência de uma espécie de egocentrismo do pensamento, bem diferente daquele da criança que inicialmente não pode diferenciar o próprio eu dos demais objetos, e quando de posse do pensamento simbólico, não pode diferenciar o próprio ponto de vista do ponto de vista alheio. No caso do egocentrismo adolescente o que ocorre é que, nas palavras do autor:

a ampliação indefinida da reflexão que permite esse novo instrumento que é a lógica das proposições leva, inicialmente, a uma indiferenciação entre esse poder novo e imprevisível que o eu descobre e o universo social ou cósmico que é objeto dessa reflexão. (Piaget, 1970/1976, p.257)

A questão é que o adolescente permanece inicialmente e por algum tempo no âmbito do pensamento, ou seja, idealiza mil formas de interação com a sociedade, planejando mentalmente a sua inserção no mundo social, refletindo sobre todas as transformações e reformas que proporá a essa sociedade. Todavia, tal processo de imaginação e idealização, afasta temporariamente o jovem da realidade palpável e por estar envolvido com suas manifestações psíquicas, pouca ação concreta se presencia nesse período.

Para Piaget, o objetivo maior dessa fase do desenvolvimento é a integração do adolescente no mundo social dos adultos, que conta, além da capacidade de abstração e construção de teorias, com dois outros aspectos fundamentais: a construção de um programa de vida e a reforma da sociedade atual. Segundo ele, a partir das interações sociais, o criador de teorias descobre, com as teorias dos outros, a fragilidade de suas próprias teorias e um processo de descentração convida a reconciliação entre o pensamento e a experiência: "É ao empreender uma tarefa efetiva que o adolescente se torna adulto e o reformador idealista se transforma em realizador".(Piaget, 1970/1976, p.257).

A teoria do desenvolvimento psicológico de Jean Piaget é a mais importante para essa pesquisa, em primeiro lugar por privilegiar a construção do raciocínio, que, segundo o estudo a que essa pesquisa se propõe, é fator importantíssimo e mais que isso, é condição necessária ao desenvolvimento moral. Em segundo lugar, além da questão da importante conquista que o adolescente faz do desenvolvimento do raciocínio abstrato, a teoria piagetiana foi a primeira a afirmar que o ser humano teria duas morais ao invés de uma: a possibilidade do 
desenvolvimento moral da autonomia pelo ser humano (Piaget, 1932/1994), e que a autonomia seria uma conquista do adolescente que alcançaria a igualdade com os adultos nas relações de reciprocidade, respeito mútuo e cooperação. Por esses motivos, a teoria psicogenética piagetiana é eleita como principal referencial teórico para essa pesquisa.

Outro teórico que explicou a adolescência como parte do processo de desenvolvimento "criativo" e "adaptativo" do ser humano foi Eric Erikson, que, embora fosse um autor de orientação psicanalista, privilegiou os fatores sociais e culturais em detrimento ao fator da sexualidade, para explicar tal desenvolvimento. Para a teoria de Erickson, a adolescência é uma fase muito importante, pois é um período decisivo na formação da identidade.

$\mathrm{O}$ autor incorporou elementos da psicanálise na sua teoria, porém ao invés de enfatizar elementos constitutivos da personalidade, como o id, ego e superego, apresentou a construção e a organização gradual do desenvolvimento da personalidade, e por isso a sua teoria é complexa e explica o desenvolvimento humano desde o nascimento do bebê até a velhice, não terminando como a maioria das outras teorias sobre desenvolvimento, na idade adulta. Segundo suas próprias palavras:

Apresentarei o crescimento humano do ponto de vista dos conflitos, internos e externos, que a personalidade vital suporta, ressurgindo a cada crise com um sentimento maior de unidade interior, um aumento do bom juízo e um incremento na capacidade de "agir bem", de acordo com os seus próprios padrões e aqueles padrões adotados pelas pessoas que são significativas para ela. (Erickson, 1968/1976, p.91)

Para o autor, a personalidade resulta da interação de três grandes sistemas: o biológico, o social e o individual, sendo que a existência humana evolui, seguindo a necessidade de manter-se em equilíbrio, superando uma a uma as crises de cada uma das oito idades do homem, por ele propostas. O conceito de crise para Erickson é o seguinte:

A palavra crise é usada aqui num sentido de desenvolvimento para designar não uma ameaça de catástrofe, mas um ponto decisivo, um período crucial de crescente vulnerabilidade e potencial; e, portanto, a fonte ontogenética da força e do desajustamento generativos. (Erickson, 1968/1976, p.96)

Ao tratar dos estágios da vida do ser humano, Erickson afirma que cada um deles apresenta suas crises, todavia, a crise da identidade acontece na adolescência, fase que, segundo o autor, o "indivíduo desenvolve os pré-requisitos de crescimento fisiológico, maturidade mental e responsabilidade social" (Erickson, 1968/1976, p.91) que o preparam para ultrapassá-la. Para ele, a resolução dessa crise implicará na consolidação da 
personalidade adulta.

Por isso, o autor fala da necessidade de uma "moratória social", isto é, os adolescentes precisam de respeito, compreensão, tolerância, espaço e tempo, para "a integração dos elementos da identidade atribuídos nas páginas precedentes às fases da infância; só que, agora, uma unidade mais vasta, indefinida em seus contornos e, no entanto, imediata em suas exigências, substitui o meio infantil: a sociedade". (Erickson, 1968/1976, p. 129). A moratória ou espera diz respeito ao tempo que o adolescente necessitará para construir a sua personalidade, ou seja, superar a crise da identidade.

Daí a sua teoria privilegiar a fase da adolescência, uma vez que é nesse período de grande significado para o desenvolvimento que o jovem precisa resolver a confusão da sua própria identidade, afirmando e organizando suas habilidades, suas necessidades, seus interesses e seus desejos, de modo que possa se constituir como pessoa única diante da sociedade. $\mathrm{O}$ resultado desse processo vivenciado na adolescência deve garantir a formação de uma personalidade saudável que, no conceito do autor, diz respeito a:

uma personalidade que domina ativamente o seu meio, demonstra possuir uma certa unidade de personalidade e é capaz de perceber corretamente o mundo e ela própria, então está claro que todos esses critérios se relacionam com o desenvolvimento cognitivo e social da criança. (Erickson, 1968/1976, p.91)

Portanto, a teoria de Erickson (1968/1976), é também uma teoria que, embora discuta o conceito de crise, inclusive na adolescência, não considera o período como fase crítica e tempestuosa, pois compreende sua importância e especificidade, porém dentro de uma evolução psicológica. Conforme já anotado nos parágrafos anteriores, a teoria de Erickson não será adotada pela presente pesquisa, todavia a referência as suas contribuições para o estudo da adolescência, não poderia deixar de estar registrada nesse capítulo.

Outra pesquisadora que é bastante citada e reconhecida nas investigações sobre a adolescência é a antropóloga Margaret Mead (1928, citada por Papalia, 1998), cujos estudos contestaram a idéia da adolescência como um período de tempestade e de tormenta. Como a autora estudou a adolescência em outra cultura (ilha de Samoa na Polinésia), observou que o processo vivenciado nesta fase, poderia ser calmo e com mudanças sociais mínimas, diferentemente das observações feitas com adolescentes americanos.

Ainda se tratando da questão da adolescência ser ou não uma fase de problemas amplificados, conflitos e dificuldades, Steinberg e Morris (2001) apresentaram uma revisão da literatura sobre desenvolvimento do adolescente e seu funcionamento psicológico, e a partir 
dessa revisão da literatura admitiram que, na verdade a adolescência ainda é considerada um período caracterizado pela tempestade e tormenta.

Segundo os mesmos, as visões de adolescência como um momento de crise, permanecem inabaláveis desde Hall (1904). Nenhuma tentativa de desenvolver uma teoria geral do desenvolvimento adolescente normal encontrou ampla aceitação. Com relação às teorias do desenvolvimento adolescente enquanto apenas mais uma fase de desenvolvimento, tiveram um declínio considerável na sua aceitação, como por exemplo, a teoria de Erik Ericson que, segundo os autores desapareceu do cenário empírico e a teoria sobre o desenvolvimento cognitivo de Jean Piaget $^{6}$ que teve algumas de suas proposições fundamentais contestadas por outras pesquisas.

Outro argumento para a manutenção da hipótese da adolescência como um período de crise, diz respeito ao fato de que a maioria das pesquisas com adolescentes é fundamentada em pesquisas com jovens portadores de problemas de comportamento, portanto a visão de adolescência saudável está atrelada ao conceito de patalogia.

A revisão de Steinberg e Morris (2001) apresentou as novas pesquisas sobre o tema, assim como, as novas direções que as pesquisas tomaram desde a última revisão de Pettersen (1988). Segundo os autores, de 1988 a 2001, houve um crescente interesse por pesquisas sobre adolescentes, o que pôde ser observado pelo surgimento de novos periódicos destinados a publicação de artigos sobre o tema, como Journal of Research on Adolescence, assim como o incremento de numerosas páginas devotadas a adolescência, em outros periódicos como Child Development, Development Psychological Bulletin.

Naquilo que diz respeito à revisão literária realizada por Steinberg e Morris (2001, p.84), os autores continuaram apontando para um incremento do interesse para o tema da adolescência e relatam à existência de quatro grandes tendências que se responsabilizam pelo crescente interesse pela área: a ampliação de pesquisas sob a perspectiva ecológica de desenvolvimento humano de Bronfenbrenner (1979, citado por Steinberg e Morris, 2001); as pesquisas interessadas no modelo biossocial dos estudos da puberdade; a atenção aos problemas de comportamentos antisociais, uso de droga, gravidez precoce e depressão e, finalmente os estudos longitudinais enfocando o desenvolvimento desde o período da préadolescência, até o ingresso na vida do jovem adulto.

\footnotetext{
${ }^{6}$ Piaget responde a algumas dessas críticas em um texto intitulado Evolução Intelectual do Adolescente ao Jovem Adulto, ver: Piaget, J. (2008). Intellectual Evolution from Adollescence to Adulthood, Human Development, 51, 40-47. Reprint of Human Development, 1972; 15: 1-12.
} 
Deste modo, os autores afirmam que as áreas de pesquisa que representam dois terços dos artigos publicados, e que, portanto, são os temas de maior importância e interesse nesse período, são: o desenvolvimento do adolescente no contexto familiar, problemas de comportamento, e a puberdade e seu impacto, ou seja, os temas são os mesmos da revisão anterior de Pettersen (1988). Além desses temas, os estudos sobre o desenvolvimento do self, e sobre o relacionamento entre pares, representam as pesquisas atuais mais expressivas a cerca do desenvolvimento da adolescência. Segundo as palavras de Steinberg e Morris (2001):

Inclusive se um visitante de outro planeta fosse analisar a recente literatura, ele poderia concluir que a vida dos adolescentes se resolve em torno de três coisas: pais, problemas e hormônios. Nós suspeitamos que essa caracterização é parcialmente verdadeira. (Steinberg e Morris, 2001, p.85) ${ }^{7}$

Segundo os autores, apesar do fato das recentes pesquisas estarem focadas, nos temas acima apontados, novas orientações têm guiado os trabalhos dos pesquisadores, e deste modo, transformado esse quadro. Concordando com a revisão de Pettersen (1988), os autores relatam que prevalecem as pesquisas mais contextuais que investigam a influência da genética e do ambiente no desenvolvimento. Afirmam ainda que os estudos sobre puberdade, ou seja, do desenvolvimento físico do jovem, apresentaram poucos progressos, assim como os estudos sobre o desenvolvimento psicossocial (identidade, autonomia, intimidade), que já foram temas centrais de pesquisas na adolescência, diminuíram consideravelmente, sendo que os pesquisadores voltaram sua atenção para as influências contextuais no comportamento e seu funcionamento na adolescência, e para o estudo das diferenças individuais. (Steinberg e Morris, 2001, p.101).

Exemplificando essa tendência, Lerner e Galambos (1998, p. 413) abordaram o processo básico do desenvolvimento do adolescente envolvendo as relações entre o individual e os múltiplos fatores do contexto com os quais os jovens se envolvem. Os autores discutiram os elementos que, dentro do contexto podem ser fatores de risco ou proteção nesse período da vida. Afirmaram que os fatores de risco são os promotores da diversidade na adolescência, e entre os adolescentes americanos se destacam o uso de drogas, de álcool, e substâncias de uso e abuso, sexo arriscado, gravidez precoce, relação pais e filhos, dificuldades de aprendizagem, fracasso escolar e desistência da escola, delinqüência, crime e violência.

Os revisores Steinberg e Morris (2001, p.102), entretanto, afirmam que, a grande necessidade no âmbito das pesquisas em desenvolvimento, diz respeito à elaboração de um

\footnotetext{
${ }^{7}$ Todas as traduções desse trabalho foram realizadas pela própria autora.
} 
estudo longitudinal sobre a adolescência que incorpore os recentes e progressivos estudos da neurociência, e os avanços metodológicos e tecnológicos dos estudos sobre a mente, a biologia e o comportamento. Segundo eles, as pesquisas sobre o desenvolvimento da adolescência devem focar a interdisciplinaridade, contando com estudos que relacionem os mais variados contextos.

Todavia, a revisão mais recente a respeito da pesquisa sobre o desenvolvimento do adolescente no contexto interpessoal e social é de Smetana, Campione-Barr e Metzger (2006). As autoras afirmam que várias tendências caracterizam as recentes pesquisas em desenvolvimento adolescente, entre elas: a abordagem ecológica que foca no entendimento dos contextos do desenvolvimento e suas influências sobre o processo do desenvolvimento; as pesquisas que focam múltiplas interações entre diferentes contextos (família, escola, vizinhança); além de estudos longitudinais. (Smetana, Campione-Barr e Metzger, 2006, p.256).

Em sua revisão, Steinberg e Morris (2001) notaram que "pais, problemas e hormônios (p.85) estavam entre os mais populares tópicos da recente pesquisa em adolescência. No novo milênio, as pesquisas continuam a enfatizar a parentalidade e a relação dos pais e adolescentes, entretanto estes relacionamentos têm sido ampliados pela consideração no contexto de, ou conectados com, outros relacionamentos, contextos (por exemplo, a influência dos pais nos relacionamentos entre pares ou a interação entre pais, pares e vizinhos), ou influências hereditárias e biológicas. (Smetana, Campione-Barr e Metzger, 2006, p.256).

Segundo as revisoras, os estudos sobre a adolescência têm se tornado mais relacionais, o que se evidencia no grande foco de pesquisas sobre o relacionamento do adolescente com a sua família e com as relações complementares que suplantam o relacionamento do adolescente com os pais. Outro importante aspecto especialmente para esse trabalho é que há atualmente uma reconsideração da autonomia como a maior conquista do processo do desenvolvimento do adolescente.

Sobre as pesquisas que investigaram a temática do relacionamento pais e adolescentes, Smetana, Campione-Barr e Metzger (2006, p.259) afirmam que "a natureza e a qualidade do relacionamento dos adolescentes com seus pais continua a ser um dos tópicos mais fortemente pesquisados na adolescência". As autoras afirmam também que as pesquisas comprovam que a extrema alienação dos pais, a rejeição ativa dos valores adultos e da autoridade, e a rebelião do jovem, são exceções e não norma, e somente uma pequena proporção de adolescentes (5 a $15 \%$ dependendo da amostra), experimentam emoções turbulentas e extremos conflitos nas 
relações com seus pais. Porém, a despeito de décadas de pesquisas, ainda persiste a percepção da cultura popular de que a adolescência é um período difícil que envolve mau humor, estresse e intencional desobediência aos pais.

Conforme os estudos apresentados no Handbook of adolescence (2006), as pesquisas sobre o relacionamento pais e adolescentes dirigem-se para as seguintes temáticas: a autonomia do adolescente, o adolescente e a diversidade familiar, a relação pais e filhos como um contexto de socialização, os estilos parentais e o ajustamento do adolescente, a abordagem sistêmica da família.

Os estudos sobre a socialização do adolescente no contexto familiar, especialmente na década de 80 e 90, tiveram sua maior expressão nas pesquisas sobre estilos e práticas parentais, pesquisas essas derivadas, segundo Steinberg e Morris (2001), de uma forma ou de outra, das pesquisas originadas na abordagem comportamental sobre o estudo dos estilos e práticas parentais, entre elas o trabalhos desenvolvidos por Bandura (1969/1979) e Baumrind (1966).

Tais pesquisas ainda hoje amplamente utilizadas desenvolveram uma metodologia própria, rigorosa e reconhecida, cujos objetivos maiores são apontar as diferentes formas de interação entre pais e adolescentes e as conseqüências dessas interações para o desenvolvimento das habilidades sociais do jovem, bem como para a sua saúde mental. Um breve resumo desses estudos e os instrumentos de pesquisa por ele utilizados, serão apresentados no quinto capítulo dessa pesquisa, capítulo esse que trata exatamente da abordagem metodológica, tão expressiva no caso da abordagem comportamental.

Os resultados de algumas pesquisas sobre o tema adolescência e autonomia serão apresentados no próximo capítulo, cujo objetivo é justamente, discutir a temática da adolescência e a relação pais e filhos. A opção foi por pesquisas com abordagem cognitivista, especialmente, aquelas que se debruçaram sobre os estudos das influências familiares sobre o desenvolvimento moral do adolescente.

Concluindo esse capítulo cujo objetivo foi tratar do conceito, das teorias e pesquisas que se ocupam da adolescência, pode-se parodiar Goossens (2006, p. 26) que, ao concluir o seu capítulo sobre teorias da adolescência no Handbook of Adolescence (2006), comenta a respeito de duas questões clássicas que organizam as teorias sobre a adolescência: a adolescência é uma fase distinta no desenvolvimento? A adolescência é realmente a fase do aumento das turbulências emocionais?

Conforme se pôde observar pelas teorias e pesquisas sobre o tema, a primeira questão que pergunta se a adolescência é uma fase distinta no desenvolvimento, tem resposta positiva 
para todas as abordagens téoricas. A segunda questão que pergunta se a adolescência é realmente a fase do aumento das turbulências emocionais (tempestade e tormenta), é mais difícil de ser respondida. De acordo com o imaginário popular, a resposta continua sendo sim, porém conforme as observações desse capítulo, as teorias, especialmente as mais recentes, bem como os resultados das pesquisas sobre a adolescência, tendem a discordar desse estereótipo imposto a essa fase. 


\title{
3 - A ADOLESCÊNCIA E A RELAÇÃO PAIS E FILHOS
}

\begin{abstract}
Os pais são centralmente importantes em virtude de sua preocupação com o bem estar e o desenvolvimento dos seus filhos, seu relacionamento afetivo e extensa história de interação com eles e sua habilidade em providenciar tipos de interações que facilitam o seu desenvolvimento moral. (Smetana, 1999, p.319).
\end{abstract}

Hoffman (1970) revisou a literatura sobre a educação dos filhos para verificar as influências das relações entre pais e filhos para o desenvolvimento moral da criança e do jovem. O autor inicia seu texto apresentando as três principais teorias que explicam o desenvolvimento moral: a teoria psicanalítica de Sigmund Freud, a teoria comportamental de B. F. Skinner e a teoria cognitivo-evolutiva do juízo moral de Jean Piaget.

Hoffman afirma que o conceito de internalização de padrões morais é o orientador da maioria das pesquisas sobre o desenvolvimento moral, sendo que, há três tipos de internalização, isto é, de proibições e ordens socialmente sancionadas: o primeiro está baseado no medo e na ansiedade condicionados, ou seja, o indivíduo é severamente punido por comportamentos inadequados e, portanto, motivado por ameaças externas o sujeito internaliza o comportamento adequado; o segundo tipo é fundamentado na referência externa, seja ela presente ou não, que é admirada e respeitada pelo sujeito, que se identifica, respeita e sente afeto por tais pessoas e por isso, age conforme o seu modelo; e finalmente o terceiro tipo de internalização, que, segundo o autor, é o mais elaborado, pois não está ligado a nenhuma referência, e sim a um processo de auto-aprovação, ou seja, apóia-se no ideal de um sentimento de obrigação para consigo mesmo. (Hoffman, 1970, p.6-7). Quanto aos dois primeiros padrões morais de internalização, representam legados de Freud, bem como do sociólogo Durkheim:

Embora sejam inicialmente externas, as normas são finalmente adotadas pelo indivíduo graças, em grande parte, aos esforços dos seus primeiros socializadores os pais -, passando a servir como guias internalizados, de maneira que ele se comporta de acordo com elas mesmo quando a autoridade externa não está presente para impô-las. Ou seja, o controle através dos outros é substituído pelo autocontrole. Como exemplos de conceitos de internalização podemos citar o "superego" de Freud e a "consciência coletiva" de Durkheim." (Hoffman, 1975/1978, p.3)

Quanto ao terceiro tipo de internalização envolve um processo interno de pensamento e julgamento, o sujeito pensa em padrões, julga o certo e o errado e, a partir dessa construção interna aceita tais padrões como seus ou não. Essa forma de internalização é explicada pela 
abordagem cognitivo-evolutiva do desenvolvimento moral, cujo principal expoente é Jean Piaget (1932).

Turiel (1998) em um artigo no qual também revisa as teorias sobre o desenvolvimento moral, escreve sobre as três teorias explicativas desse desenvolvimento. Segundo ele a psicanálise é a mais extensa produção escrita sobre a moralidade: "Na visão freudiana, a aquisição da moralidade resulta na dualidade entre o individual, incluindo as forças do superego e as necessidades de gratificação do instinto. O lado moral da dualidade impõe deveres para defender as normas sociais”. (Turiel, 1998, p.864). Para ele a internalização apropriada da moralidade é invariável e inflexível.

As recentes pesquisas a respeito dessa temática, são categorizadas como pesquisas que investigam a chamada autonomia emocional, ou seja, o estudo do desapego com os pais, fruto das modificações providas pela puberdade, que levam o adolescente a destruir a visão idealizada dos pais como heróis que nunca erram e a elaborar uma visão dos mesmos como indivíduos que também têm a sua própria vida, além de serem pais e mães. (Goossens, 2006, p.145).

Para essas pesquisas, quanto maior a separação dos pais ao longo do desenvolvimento da adolescência, os jovens tenderiam a apresentar maior equilíbrio psicológico, ou seja, maior autonomia emocional. Entretanto, os resultados das pesquisas, têm sido contrários a essas expectativas, demonstrando que os adolescentes com altos índices para a separação emocional dos pais, mostram maior envolvimento com todo tipo de problemas de comportamento. É por esse motivo que dentro dessa perspectiva teórica, o debate da adaptativa e mal-adaptativa natureza da separação emocional do adolescente em relação aos pais produz consideráveis discussões. (Goossens, 2006, p.145).

A abordagem psicanalítica, seja sobre os estudos de internalização dos valores morais, ou os estudos mais recentes sobre a autonomia emocional, não serão utilizados por essa pesquisa, uma vez que, seu objeto de estudo é a participação dos pais na construção da autonomia moral, compreendida enquanto conjunto hierárquico de valores que norteiam a elaboração de um plano de vida por parte do adolescente.

A respeito da abordagem comportamental da moralidade, presente na formulação skinneriana, Turiel (1998, p. 864) afirma que, para essa teoria a moralidade reflete comportamentos que tenham sido positivamente ou negativamente reforçados, segundo as normas sociais. Desse modo, as ações não são para os sujeitos intrinsicamente boas ou más, mas são adquiridas e executadas como uma conseqüência da contingência dos reforços. "Além disso, o controle social sobre o comportamento é particularmente mais poderoso 
quando é exercido pelas forças institucionais (religião, governo, economia, educação)". (Turiel, 1998, p.64).

A abordagem a comportamental define o desenvolvimento da moral como o resultado das interações com o meio, seja através da introjeção de modelos ou através do resultado das práticas parentais a que o sujeito é submetido, negligenciando desse modo, o elemento essencial da teoria piagetiana que é ação do indivíduo.

A respeito das práticas parentais, o trabalho de Baumrind (1966), originário da abordagem comportamental, apresentou três modelos de intervenções dos pais, nos quais a autora aborda aspectos comportamentais e afetivos envolvidos na criação dos filhos: o modelo denominado autoritativo, o autoritário e o permissivo. Nesses modelos a autora enfatiza a autoridade que os pais exercem sobre os filhos como forma de controle de comportamento e possibilidade de imposição de suas crenças e valores. O primeiro modelo é considerado pela autora como o mais competente, o segundo inclui o uso da força física e outros procedimentos questionáveis e inadequados, e o permissivo, é justamente aquele que não cumpre o seu papel na educação dos filhos.

Um crescente número de pesquisas interessa-se pelo estudo e classificação dessas condutas dos pais, e suas consequiências na formação dos jovens filhos, conforme os exemplos que se seguem: Lamborn, Mounts, Steinberg e Dornbusch (1991) que investigaram o padrão de ajustamento e competência do adolescente, de acordo com o estilo parental de seus pais: autoritativo, autoritário, indulgente ou negligente; Darling e Steinberg (1993), que apresentaram um modelo integrativo de estilos parentais apresentados como contexto que influenciava o desenvolvimento do adolescente e da criança; Costa, Teixeira \& Gomes (2000), cujo estudo traduziu, adaptou e comparou duas escalas que avaliam as dimensões responsividade e exigência parentais com adolescentes; Weber, Prado, Viezzer e Brandenburg (2004), investigaram através das escalas adaptadas de Costa e colaboradores (2000), as famílias brasileiras no tocante aos estilos parentais mais utilizados por elas, tanto quanto o ponto de vista dos filhos acerca dos estilos parentais dos pais; Carvalho e Gomide (2005), investigaram o estilo parental em famílias de risco, ou seja, cujos filhos adolescentes estavam em confronto com a lei; Salvo, Silvares e Toni (2005), cujo estudo constituiu em avaliar as práticas educativas como forma de predição de problemas de comportamento e competência sócia; Gomide (2006) elaborou um instrumento fundamentado nas teorias de Baumrind, o Inventário das Práticas Parentais, e realizou a partir dele, cinco estudos, em busca da validade do instrumento; Teixeira, Oliveira e Wottrich (2006) cujo estudo avaliou as dimensões das práticas parentais, elaborou e validou um novo instrumento de pesquisa, e encontrou o 
resultado de correlações entre práticas parentais e indicadores de desenvolvimento psicossocial.

Outros exemplos que podem ser citados, são os estudos como os de Pratt, Arnold, Pratt e Diessner (1999), que investigaram o raciocínio moral de adolescentes conforme as práticas parentais que se sobressaem das famílias das quais tais jovens se originam; os estudos de Camino, Camino e Moraes (2003) que também investigaram sobre práticas maternas de controle social e julgamento moral.

Essa abordagem será retomada quando do estudo dos instrumentos de pesquisa, no capítulo cinco desse trabalho, uma vez que, as pesquisas realizadas a partir dos trabalhos de Baumrind (1970), contam com um número significativo de instrumentos de medidas, pois buscam comparar as práticas e estilos parentais e identificar a predição de cada tipo de prática para com os comportamentos anti-sociais, o desempenho escolar e outras questões. Exatamente por esse caráter unidimensional e de causalidade do contexto familiar para com o desenvolvimento psicológico e a socialização da criança e da adolescência, essa não é a abordagem teórica e nem metodológica a ser adotada pelo presente trabalho.

Comparando as três abordagens quanto ao papel da experiência social, Hoffman (1970) afirma que para a teoria psicanalista e comportamental, as experiências sociais são impreterivelmente importantes, uma vez que, através delas as autoridades fornecem às crianças padrões definidos e viabilizam às mesmas os motivos necessários para que adotem tais padrões, ou seja, o ambiente social desempenha um papel modelador direto.

Com relação à abordagem cognitivo-evolutiva, o autor afirma que a experiência social não tem efeito direto sobre o sujeito, mas é incorporada às estruturas cognitivas existentes, não no sentido adicional, mas providenciando a construção de uma nova estrutura. Nas suas palavras: “A experiência social, então, não leva diretamente a uma nova direção moral: seu papel, ao invés disso, limita-se a estimular ou desafiar o indivíduo a reorganizar seus padrões preexistentes de pensamento moral". (Hoffman, 1970, p. 15).

A abordagem cognitivo-evolutiva também foi abordada por Turiel (1998, p.864). Referindo-se a pesquisa de desenvolvimento moral de Jean Piaget apontou conceitos centrais nas formulações do autor acerca do tema: a primeira diz respeito ao fato da moralidade para Piaget não se tratar apenas de reprodução de transmissão social, mas para ele a moralidade do sujeito acarreta uma reconstrução, concordando, portanto, com Hoffman.

O segundo conceito observa que a moralidade é fruto de diversas influências incluindo reações emocionais, relacionamento com adultos e relacionamento entre pares. O terceiro conceito afirma que o juízo moral é fundamentalmente constituído sobre relacionamentos 
interpessoais, com um desenvolvimento progressivo que segue em direção ao sentimento de respeito mútuo entre as pessoas, em direção a assuntos que atingem e sustentam as relações sociais de cooperação, e à formação da noção de justiça por igualdade, e da habilidade para considerar as perspectivas dos outros, como possibilidades diferentes das próprias perspectivas.

O terceiro conceito descrito por Turiel (1998) acerca da teoria de Piaget, também foi discutido por Hoffman:

Essa adoção mútua de papéis facilita na criança o desenvolvimento da consciência de que ela é um indivíduo que está relacionado com os outros, mas é diferente deles, isto é, de que pensa e sente como eles em situações similares, de que as consequiências de suas ações em relação a eles e deles em relação a ela são similares e, ainda, de que os eventos parecem diferentes quando considerados sob diferentes pontos de vista. (Hoffman, 1970, p.12)

Quanto ao segundo conceito, Hoffman também apresentou sua contribuição, especialmente no tocante ao aspecto da importância, para Piaget, do relacionamento com adultos para o desenvolvimento da moralidade. Muitos teóricos e pesquisadores (Papalia, 2006, p.462), afirmaram que Piaget não considerava os pais importantes para o desenvolvimento moral das crianças, todavia:

Embora salientando a importância dominante da interação entre os companheiros, Piaget, em várias passagens raramente citadas, deixa claro sua crença de que as práticas de criação infantil adotadas pelos pais também podem desempenhar um papel significativo no desenvolvimento moral. Segundo ele, os pais tendem a ser autoritários em suas práticas e, como conseqüência disso, ajudam a consolidar a tendência natural da criança em direção à heteronomia. Se, ao invés disso, modificassem sua maneira de ser e propiciassem condições para a criança interagir com eles de forma recíproca, tal fato aumentaria a probabilidade de que a autonomia moral se estabelecesse firmemente. (Hoffman, 1970, p.13).

Partindo dessa abordagem de pesquisa, Hoffman (1970) propôs três conceitos de criação infantil e comparou os seus resultados sobre o desenvolvimento moral, ou seja, verificou em laboratório, assim como ele mesmo escreveu, a partir das pesquisas empíricas, quais são as formas de criação aplicadas pelos pais que mais produzem conseqüências positivas para o desenvolvimento moral dos filhos. $\mathrm{O}$ autor chamou as três formas de afirmação de poder, retirada do amor, indução. Apresenta-se a seguir um resumo de suas principais características:

O autor nomeou como afirmação de poder: "a expressão é utilizada para deixar claro o fato de que, ao empregar essas técnicas, os pais procuram controlar a criança valendo-se do 
seu poder físico ou através do controle de recursos materiais" (Hoffman, 1970, p.44). Esse tipo de educação negligencia todos os recursos internos da criança, mas a obediência é conseguida através de ameaças, punições, recompensas, castigos físicos, enfim, do medo que a criança sente em relação a essa imposição das regras por parte dos seus pais.

A afirmação do poder alimenta a imagem dos pais como pessoas que punem, que agem de forma arbitrária, e por isso, alguém que deve ser evitado, e não alguém de quem se possa aproximar ou alguém que se queira imitar. Posteriormente esse tipo de percepção diminui a influência do pai e faz com que a criança aprenda a controlar as suas ações prevendo as conseqüências externas impostas pelo adulto, como por exemplo, o caso das crianças que elaboram cada vez mais mentiras para não "serem pegas" e então punidas pelos pais. Portanto, não há aprendizagem de controle interno, o que significa compreensão e legitimação das regras.

La Taille (1998, p.97), comentando essa forma de educar tão freqüentemente utilizada pelos genitores, afirma que o resultado mais comum desse tipo de educação é a formação de pessoas que se habituam a obedecer sem contestar ou refletir sobre as regras. Todavia, segundo o autor, tal educação traz um aspecto positivo, que é a definição dos limites por parte dos pais. Bem se sabe que a ausência de limites para as crianças tem conseqüências caóticas para as mesmas, tanto que o ato de mimar a criança é considerado abuso psicológico infantil, segundo a pesquisa de Marques (2000, p.207): “o fato de 'mimar' deve ser considerado como psicologicamente abusivo, tendo em vista que, a longo prazo, ela desenvolverá o egoísmo, o narcisismo e o egocentrismo".

Em um estudo sobre o conceito de obediência de pais e mães, Caetano (2005, p.129), apresentou relatos de respostas de pais que ilustram essa forma de educação fundamentada na imposição da autoridade para fazer obedecer às crianças:

Erguer a voz, fazer maior pressão, dou uma bronca, sou mais rígido, dou uns trancos, eu imponho limites, se tiver que falar não, pode chorar que vou falar não, quando preciso algumas palmadas ajudam, meu filho me obedecendo ele sabe que vai ter o melhor de mim, é a lei da ação e reação, faço cara feia e falo forte, eu tiro o vídeo-game, se não obedecer vai ter um castigo, eu digo que eu não quero e acabou!, mudo a expressão do rosto, por isso ela tem aquele impacto, aquele medo, aí ela ouve, e se você usa da sua autoridade costuma dar certo.

A segunda forma de educação proposta por Hoffman, a retirada de amor, também é ameaçadora para a criança, não no sentido de uma ameaça física ou material, mas a ameaça do abandono e da separação. A sua ação é muito mais prolongada que a primeira forma de 
educação, que embora também seja constituída de ações aversivas, tem uma ação rápida e bastante objetiva. Segundo o autor, essa forma, por sua vez, não tem previsão para terminar, e a rejeição, a humilhação, podem se prolongar indefinidamente. Esse tipo de educação é considerado por ele, ainda mais prejudicial.

O autor exemplifica: "ignorar a criança, voltar às costas para ela, recusar-se a falar com ela ou recusar-se a ouvi-la, manifestar abertamente à criança o seu desagrado em relação a ela e isolá-la ou ameaçar abandoná-la”. (Hoffman, 1970, p.44). Segundo Hoffman, a técnica da retirada do amor produz a separação entre pais e filhos, pois tende a produzir ansiedade nas crianças, reduzindo ou impedindo a comunicação entre ambos. A ansiedade provocada prejudicará a compreensão da criança e a impedirá de vivenciar a empatia com a situação conflituosa, fato que lhe ajuda a dirigir a sua atenção para as conseqüências do ato cometido em relação aos outros.

Para Marques (2000, p.206), o tratamento desdenhoso ou com desprezo, que inclui insultos, humilhações, imposição de culpa, tratamento hostil e de rejeição; a negação da reciprocidade emocional, explicada pela postura de ignorar a tentativa da criança interagir, a separação da mesma do ambiente ou do convívio; e responder a ela com indiferença e sem afeição; o tratamento terrorista; ou seja, atos que causem extremo medo ou ansiedade à criança ou adolescente, também se constituem em categorias consideradas abuso psicológico, e, portanto, a educação pela retirada do amor, pode da mesma forma ser considerada prejudicial à saúde mental da criança e do adolescente.

O problema das chantagens emocionais e da ameaça de perder o amor do adulto como forma de fazer a criança obedecer é apresentado por La Taille (1998, p.98), a partir da definição de dois elementos negativos que desaconselham à utilização desse tipo de educação: o primeiro diz respeito à pesada carga emocional, forte e angustiante, que é imposta aos filhos quando submetidos constantemente à ameaça da perda do amor dos pais - tal processo pode desencadear desequilíbrio afetivo posteriormente; e o segundo elemento, diz respeito ao fato de que, esse tipo de educação conduz a construção de uma moralidade fundamentada exclusivamente na culpa.

A terceira forma de educação proposta por Hoffman foi denominada indução, e definese como "técnicas nas quais os pais dão explicações ou razões para conseguir que a criança mude seu comportamento" (Hoffman, 1970, p.45). Para o autor, dentre as três estratégias apresentadas, a indução é a maneira mais eficaz para a promoção do desenvolvimento moral da criança, sendo quatro os seus principais argumentos: 
1- Os pais são modelo de autoridade racional e não arbitrária pois não usam de técnicas como ameaças, punições e recompensas. Quando por outro lado usam punições e recompensas, isso conduz obviamente, a formação de uma imagem de pais punitivos ou recompensadores;

2- Oferecem as crianças oportunidades de pensar e refletir sobre os próprios atos, o que fornece às crianças recursos cognitivos necessários para desenvolver o auto-controle posteriormente, portanto, possibilita a autonomia.

3- Centralizam sua atenção para o ato a ser corrigido, o que ensina a criança a arcar com as conseqüências dos seus atos, e nesse sentido, ampliar a sua capacidade de motivação interior para não voltar a cometer o mesmo ato novamente.

4- Orientam a criança fazendo-a observar as consequiências de seus atos para com os outros, dirigindo a atenção da criança para o sofrimento de outras pessoas e explicando sua natureza, se não for óbvia, eliciando uma resposta empática.

Alguns pais investigados por Caetano (2005), também afirmaram utilizarem essa forma de educação, sendo que, algumas de suas expressões sobre esse modo de educar são apresentadas a seguir:

Conversar bastante, explicar que a vida tem certo e errado, não é só a vontade da mamãe, primeiro ele se explica, ele pode argumentar, eu sempre explico e digo o porquê, aquilo é uma regra por tal motivo, conversando a gente resolve as situações, eu quero compreensão, compreensão é fundamental, eu falo de uma maneira que ela entenda, procuramos dar escolha, pois a criança tem que colocar suas idéias. (Caetano, 2005, p.130)

Comentando finalmente essa última forma de educação, La Taille (1998, p. 100) afirma que: "essa associação entre limites e justificativas racionais prepara para a conquista da autonomia, que pressupõe justamente uma apreensão racional dos valores e das regras". É claro que, conforme Hoffman (1970, p.127) alerta, "todas as técnicas disciplinares possuem componentes de afirmação de poder, de retirada de amor e de indução", e que, na verdade essa distinção proposta por ele tem objetivos didáticos.

Porém a essência de suas orientações, quando bem aplicadas pelos genitores, pode ser extremamente positiva para a educação moral dos filhos. Hoffman (1970) apresenta quatro aspectos considerados por ele como fundamentais para a questão da educação moral, sendo esses aspectos, conclusões relativas aos resultados de suas pesquisas, e que, desse modo, podem ser utilizados como "bons conselhos" para a intervenção junto as crianças e aos adolescentes. 
1- A moralidade essencialmente externa é típica da teoria da aprendizagem social, que se constitui na recompensa e punição dos comportamentos pela autoridade, e para que tais processos possam continuar através da vida como base para os comportamentos morais, as contingências de reforçadores devem prevalecer nos agentes socializadores posteriores.

2- Para que a moralidade não seja externa, arbitrária e repressiva, mas objetiva, racional e legitimada pelo sujeito, o mesmo deve interagir com autoridades que usam induções compreensíveis e sensatas em termos da experiência da própria criança, além da própria experiência do indivíduo que ao se desenvolver cognitivamente assume o papel da autoridade.

3- O terceiro ressalta a socialização de impulsos anti-sociais causada pela convivência com autoridades que retiram o amor contingentemente, providenciando estados de ansiedade e culpa que sempre retornarão toda a vez que as normas da sociedade forem violadas.

4- $\quad \mathrm{O}$ quarto processo diz respeito ao desenvolvimento da moralidade fundamentada na capacidade da criança de experimentar a empatia. Para o autor, "esse padrão inclui técnicas disciplinares usadas pelos pais que promovem a experiência simultânea de empatia e consciência dos efeitos danosos das ações de alguém sobre os outros". (Hoffman, 1970, p.153).

Shaffer (2005, p.531) comenta os resultados da pesquisa de Hoffman, afirmando o porquê da disciplina fundamentada na indução ser eficaz, uma vez que, para essa autora, oferece as crianças padrões cognitivos, permite aos pais falar dos afetos morais e, nas suas palavras: "A indução pode ser um método eficaz de socialização moral, porque chama a atenção para os aspectos cognitivos, afetivos e comportamentais da moralidade e pode ajudar a criança a integrá-los".

Para Maccoby e Martin (1983) vários pontos de vistas diferentes influenciaram a pesquisa psicológica da interação entre pais e filhos. Ao tratarem da socialização no contexto familiar, revisando também toda a literatura a respeito do tema, os autores apontaram uma abordagem histórica que orienta a compreensão desse processo de interpretação da adolescência sendo os conflitos de geração, o principal tema norteador da revisão. Segundo eles, a teoria psicanalítica dominou os trabalhos sobre o tema entre as décadas de 50 e 60 , sendo que, para essa concepção, o objetivo maior da adolescência significava o rompimento com os pais, o que providenciava conflitos. Entretanto, as pesquisas das décadas de $70 \mathrm{em}$ diante, (abordagem cognitivista ou comportamental), concordaram com a existência de 
conflitos entre pais e adolescentes, mas não necessariamente que tais conflitos implicariam em rompimento. A maioria delas definiu a reconstrução dessa relação em termos de ampliação da cooperação, respeito mútuo e reciprocidade.

A questão expressa por todas essas revisões diz respeito a uma perspectiva muito peculiar na relação entre pais e adolescentes: o desafio da independência e a regressão para a dependência. A adolescência é a passagem da criança para o mundo adulto e não há retorno. Conforme $\operatorname{Ginot}^{8}$ (1989) apresenta com linguagem objetiva e, porque, não, poética, não se pode negar a existência do conflito:

Há também um conflito. Como pais, precisamos ser necessários. O de que os adolescentes precisam é não precisar de nós. O conflito é real e nós o experimentamos diariamente, enquanto ajudamos aqueles que amamos a se tornarem independente de nós. Este pode ser nosso melhor momento. Deixá-los ir, quando queremos retê-los, requer grande generosidade e amor. Somente os pais são capazes de tão penosa grandeza.

Segundo Lopes (1994) os diferentes modelos evolutivos que investigam a natureza da relação com os pais na adolescência, têm, em relação a essa questão do conflito, uma contradição inerente aos próprios modelos, que diz respeito à ênfase na continuidade ou na descontinuidade das relações entre pais e filhos. "A principal questão é em que medida o desenvolvimento se dá na direção de um maior distanciamento dos pais ou de uma maior mutualidade." (Lopes, 1994, p. 60). Para a autora, esse problema é um dos eixos de discussão do contexto familiar no desenvolvimento da autonomia moral da adolescência.

A idéia de que o objetivo maior da educação moral é a autonomia, pertence a Piaget. Ao prefaciar a edição brasileira do livro "O juízo moral na criança" (1932), La Taille (1994, p. 10), afirma que tal obra representa um marco na história da reflexão humana sobre a moralidade, e que, portanto, Piaget foi o pioneiro a abordar o tema da moralidade dentro de uma abordagem cognitivista.

Assim, sendo o problema dessa pesquisa, investigar a contribuição dos pais sobre a construção da autonomia moral do adolescente, e, entendendo a autonomia como fruto de relações de cooperação que permitem ao sujeito a possibilidade de um maior entendimento equilibrado da justiça, o que lhe permitirá a adaptação do seu eu ao coletivo, registra-se mais uma vez a opção teórica dessa investigação pelas pesquisas de abordagem cognitivista, sendo a teoria do juízo moral de Piaget, seu principal referencial teórico.

\footnotetext{
${ }^{8}$ Haim Ginot (1922-1973), psicólogo clínico, terapeuta infantil e educador cujos livros revolucionaram os relacionamentos de pais e professores com as crianças. Seus livros foram traduzidos para 30 idiomas.
} 
Conforme as palavras do próprio Piaget (1932/1994, p. 295) “a lógica é uma moral do pensamento, como a moral, uma lógica das ações”. Para o autor há um paralelismo entre o desenvolvimento cognitivo e o desenvolvimento moral, sendo que o pensamento lógico é condição necessária, embora não suficiente para ação moral, cujos conteúdos são os deveres. Piaget tem como conceitos-chave de sua teoria do desenvolvimento moral, a heteronomia e a autonomia, sendo essa última, fruto das relações de cooperação.

No que se refere à lógica, a cooperação é primeiramente fonte de críticas (porque analisa, discute, verifica), e ao mesmo tempo fonte de valores construtivos: "tende sobretudo, para a tomada de consciência da lógica das relações, para a reciprocidade no plano intelectual". (Piaget, 1932/1994, p.300).

Outros pesquisadores que compartilharam dessa mesma abordagem cognitivista, desenvolveram suas teorias partindo dos conceitos piagetianos de moral. Dentre eles, Kohlberg (1981, 1984, 1987), o psicólogo americano, cujas pesquisas influenciaram com tanta significância o campo da investigação da psicologia do desenvolvimento moral que, muitos ignoram o fato de que seus estudos se constituíram numa ampliação e reconstrução de conceitos piagetianos como a autonomia. Kohlberg é considerado o pesquisador mais famoso e conhecido nessa área. (Freitag, 1992, p.192).

Kohlberg $(1981,1984,1987)$ - diferentemente de Piaget que entrevistou crianças (1932) - pesquisou os adolescentes e adultos. Utilizando o mesmo método piagetiano de investigação - a entrevista clínica - aplicou dilemas, sendo o dilema de Heinz ${ }^{9}$, por ele elaborado, o mais conhecido dilema, entre os instrumentos de investigação moral.

Também desenvolveu uma teoria fundamente em estágios ${ }^{10}$ com sucessão invariável, já que seu maior objetivo de investigação não eram as respostas dos participantes, mas a compreensão das estruturas de pensamento subjacentes a tais respostas e que justificavam as decisões dos sujeitos. E, assim como Piaget (1954/1994), acreditava que, tanto o desenvolvimento cognitivo como as experiências sociais relevantes se constituem como fundamentos do desenvolvimento moral.

Portanto, conforme Biagio (2006, p.23), a questão da sequiência invariável dos estágios, a universalidade dos conteúdos que compõem a moral, são pontos em comuns para Piaget e

\footnotetext{
${ }^{9}$ O dilema de Heinz tem resumidamente o seguinte conteúdo: Um homem tem a sua esposa muito doente. Um farmacêutico possui o remédio que pode salvar a mulher, porém pede um preço altíssimo pelo medicamento. $\mathrm{O}$ marido não consegue angariar recursos suficientes para comprar tal remédio. $\mathrm{O}$ que deve fazer o marido? Desrespeitar a lei e roubar para salvar a vida da esposa, ou agir conforme a lei? O que é mais justo? Este contexto caracteriza o intitulado dilema de Heinz, “...o dilema mais famoso da psicologia moral..." (La Taille, 2002, p.17)

${ }^{10}$ Os estágios do desenvolvimento moral, segundo Kohlberg, estão apresentados nesse trabalho, no próximo capítulo que trata da adolescência e a construção da autonomia moral.
} 
Kohlberg. "Em relação a Piaget, parece que Kohlberg apresenta uma conceituação mais precisa e discriminada dos estágios da moralidade, sob os quais também perpassa a dimensão da heteronomia-autonomia. (Biagio, 2006, p.23).

Segundo Turiel (1998, p.866), Kohlberg também realizou uma revisão das teorias psicanalíticas e comportamentais, no tocante a questão daquilo que era considerado o mais importante nas práticas parentais como disciplina que determinava a aquisição da consciência, da culpa e do comportamento moral. A partir do resultado dessa revisão, realizou algumas críticas, especialmente, em relação aos instrumentos utilizados nas pesquisas dessas abordagens, considerados por ele como inadequados. Porém, a maior crítica apresentada por Kohlberg foi no sentido de que tais abordagens desconsideravam o fator cognitivo no tocante ao desenvolvimento moral e, segundo essas propostas, a moralidade persistiria sempre no seu domínio convencional, isto é, aquele imposto pela sociedade, ou cultura, portanto, heterônoma.

A pesquisa de moralidade dentro da abordagem cognitivista, portanto, possui o diferencial de considerar os vários fatores que influenciam o indivíduo para que ele construa os seus valores morais. Claro que é necessário levar em conta os valores sociais para compreender esse processo, e a questão é exatamente essa, que nem todos os valores sociais são morais. "Precisamos também levar em conta como a moralidade interage e é influenciada por valores sociais e considerações amorais, pois ambos estruturam os sistemas sociais e produzem os julgamentos morais dos indivíduos". Nucci (2000, p.73).

O conceito que distingue as regras morais das convenções sociais foi elaborado por Turiel (1983) e sua teoria ficou conhecida como a Teoria do Domínio Social. Os conceitos morais são compreendidos como universalmente aplicáveis, obrigatórios, impessoais e normativamente comprometedores, uma vez que as transgressões morais são erradas por terem efeito sobre os direitos e bem estar dos outros.As regras de convenção social por outro lado, provêem o indivíduo com expectativas a respeito do comportamento adequado em diferentes contextos sociais.

Para Kohlberg (1981, 1984, 1987), os primeiros estágios da moralidade, estão muito mais guiados pelos domínios pessoal e convencional, ou seja, por condutas idiossincráticas, e por regras obrigatórias conforme a cultura ou sociedade na qual a pessoa vive, enquanto os estágios mais altos da moralidade, atingidos por uma minoria da população, são guiados pelos princípios universais como justiça, harmonia social e bem-estar alheio.

Naquilo que diz respeito à relação pais e adolescentes, é interessante afirmar que, existe um número muito restrito de pesquisas voltadas para esse tema dentro dessa abordagem 
cognitivista. Piaget (1948/2000), quando escreveu a respeito da educação moral se dirigiu mais aos educadores, tendo Kohlberg $(1981,1984,1987)$ seguido esse mesmo percurso.

Segundo Walker e Taylor (1991) que se dedicaram a pesquisas voltadas para o tema da interação familiar no desenvolvimento do raciocínio moral, o motivo desse posicionamento dos autores pode ser uma reação contra a abordagem psicanalista que explica a moralidade a partir do processo de identificação com os valores paternos e que definem a autonomia como a independência em relação a tais figuras. "Como conseqüência, tem havido poucas pesquisas da família como um contexto para o desenvolvimento do raciocínio moral”. (Walker e Taylor, 1991, p.264).

Esses autores realizaram um estudo, no qual investigaram o nível de raciocínio moral dos adolescentes, segundo os estágios de desenvolvimento moral de Kohlberg e, analisaram também os estilos de relacionamento entre pais e filhos e a sua relação com o desenvolvimento do raciocínio moral, utilizando para isso dilemas hipotéticos e um dilema real descrito pelos próprios adolescentes participantes. $\mathrm{O}$ resultado foi bastante interessante, pois se observou que as crianças que apresentaram um progresso no nível de desenvolvimento do raciocínio moral, eram filhos de famílias que trocavam pontos de vista com os filhos. (Walker e Taylor, 1991, p.280).

O resultado dessa pesquisa apontou, portanto que, "o estilo dos pais que melhor predisse o desenvolvimento moral foi o representacional (eliciar as opiniões da criança, fazer questões esclarecedoras, parafrasear e checar a compreensão), bem como a interação com apoio" (Lopes, 1994, p.66). Pode-se afirmar que a interação entre pais e adolescentes fundamentada no diálogo e troca de pontos de vista conduz a um progresso do nível de desenvolvimento moral, logo, à crescente autonomia do jovem. Esse estudo constatou que a moralidade é definida no contexto das relações como uma capacidade crescente de reciprocidade.

Esse é o conceito de autonomia da teoria piagetiana, que é definida no contexto relacional, ou seja, a partir da vivência da cooperação, ao invés da individualidade, e encaminha à construção de um eu adaptado ao coletivo. (Piaget, 1970/1976). Segundo Youniss e Smollar (1985), essa é a diferença do conceito de autonomia entre Piaget e Kohlberg: Para o primeiro ser autônomo é superar o egocentrismo em prol de uma consciência do bem comum. Para o último, o desenvolvimento caminha em direção à autogestão, e, "a moralidade autônoma é definida no contexto de um maior distanciamento das relações. O self-racional é a principal meta do desenvolvimento". (Youniss e Smollar, 1985).

As pesquisas de Youniss e Smollar (1985), também representam uma contribuição importante para essa temática. Fundamentados na teoria piagetiana do desenvolvimento 
moral, os autores apresentam oito estudos desenvolvidos para avaliar os diferentes aspectos das relações dos adolescentes com os pais.

Utilizando entrevistas e questionários, elaborados a partir de suas pesquisas e estudos, os autores investigaram o papel das relações no desenvolvimento psicológico da adolescência, além de buscarem categorizar os fatores imbricados nessas relações, tanto parentais, quanto com os amigos, investigando questões de gênero, a comunicação entre pais e adolescentes, entre adolescentes e amigos, os processos de cooperação, individuação e co-construção da identidade, as diferenças entre as relações parentais e as relações entre pares e suas respectivas influências para o desenvolvimento da adolescência.

Com relação ao tema da construção da autonomia moral, os resultados dessa pesquisa são bastante expressivos e pertinentes, uma vez que redifinem o conceito de autonomia piagetiano, no sentido de buscar explicar o problema investigado pelas grandes correntes que pesquisam a adolescência na relação pais e filhos aqui apresentadas, cuja principal discussão diz respeito exatamente ao processo de vinculação e separação, conforme apontam os autores que revisaram tal literatura. (Montemayor, 1983, Maccoby \& Martin, 1983, Steinberg \& Siverberg, 1986, Silverberg e Steinberg, 1987, Petersen, 1988, Turiel, 1998, Laursen, Coy \& Collins, 1998, Steinberg \& Morris, 2001, Oliva, 2004, Shaffer, 2005, Papalia, 2006).

Os dados da pesquisa de Youniss e Smollar (1985, p.167), apresentam a ênfase na importância da posição das relações na elaboração do conceito de autonomia. Conforme as palavras dos próprios autores:

O que nossos dados adicionalmente apresentam é uma demonstração de que durante a adolescência, quando a autonomia começa a ser desenvolvida, os adolescentes vêem muito sentido numa responsabilidade pelas outras pessoas, a saber, seus amigos e seus pais. Parece implausível argumentar que os adolescentes repentinamente não encontrem necessidade de se fazerem entender a si mesmos por estas pessoas, nas quais eles previsivelmente mais confiam para o autoentendimento. [...] Por isso nós sugerimos que uma análise relacional adicione um elemento crítico para o conceito de autonomia. Adolescentes não somente cooperam com os outros construindo a realidade, mas eles fazem isso com muita consciência de que eles necessitam explicar a si mesmos para os outros ou arriscam-se a autoilusão ou egoísmo. (Youniss \& Smollar, 1985, p.167).

Para esses autores, dois conceitos são importantíssimos: co-construção cooperativa e o indivíduo-nas-relações. A partir de suas pesquisas procuram explicitar o papel dos relacionamentos no desenvolvimento do raciocínio do adolescente. Em se remetendo a essa pesquisa, Lopes (1994, p.63) afirma que para a teoria cognitiva as relações são entendidas como um meio para alcançar a autonomia, porém segundo os resultados das pesquisas de 
Youniss e Smollar (1985), os relacionamentos, inclusive o relacionamento parental, têm um fim em si mesmo, que é constituir-se como o elemento que auxilia o adolescente a se autoconhecer e ampliar o desenvolvimento do seu raciocínio e identidade.

Naquilo que diz respeito à relação pais e filhos, os autores afirmam que a adolescência é um tempo importante de transformações nas relações pais e adolescentes, porém isso não implica em rompimento, tempestade ou tormenta, ou conflitos terríveis. Essa pesquisa é um exemplo dentre aquelas, cujos resultados questionam a abordagem psicanalítica que considera o período da adolescência, como um momento de crise, no qual o crescimento dos problemas entre pais e filhos, se evidencia de tal forma a conduzir ao rompimento das relações entre eles, no final desse processo. (Silverberg \& Steinberg, 1987, Petersen, 1988, Steinberg, 2001, Steinberg e Morris, 2001).

Os resultados das pesquisas de Youniss e Smollar (1985) são apresentados a seguir, apontando algumas conclusões sobre a relação pais e filhos, que se constituem em aspectos bastante importantes para a compreensão dessa temática:

1- Obviamente ocorre na adolescência uma separação dos filhos em relação aos pais, inclusive, uma separação concreta, no sentido de que, o tempo que os filhos passam junto aos seus pais é consideravelmente menor. Os adolescentes (no caso os adolescentes que participaram da pesquisa eram americanos) passam em média 6 horas por dia na escola, depois têm suas atividades extracurriculares como esportes, divertimentos, e uma atividade social que se amplia, de forma que, o controle que os pais têm sobre sua vida e sobre sua privacidade, e consequentemente, sobre suas atitudes, pensamentos e sentimentos é sensivelmente diminuído. Os dados das pesquisas afirmam que os pais passam a saber da vida de seus filhos, na maioria das vezes aquilo que os mesmos lhes contam, e que, especialmente com relação aos pais (sexo masculino), a freqüência com que os adolescentes o fazem é bastante baixa. (Youniss \& Smollar, p. 77)

2- Por outro lado, os dados refletem também que, mesmo mais "separados ou distantes", os adolescentes (proporção significativa) mantêm definida uma conexão com seus pais, respeitando-os e sentindo-se respeitados pelos mesmos. Os adolescentes procuram atingir as expectativas, agradar e buscar a aprovação dos seus pais. Ainda, mesmo que os pais lhes dêem mais liberdade e maior privacidade, os jovens buscam manter os pais informados sobre a sua vida, e procuram o seu aconselhamento. Finalmente os adolescentes reconhecem os pais em seu papel de educadores, na medida em que os percebem preocupados com o seu próprio bem estar. (Youniss \& Smollar, p. 78).

3- As pesquisas ainda mostraram que o relacionamento do adolescente com suas mães, 
têm características diferentes do que o relacionamento dos mesmos com os pais. As mães mantêm um contato regular com os filhos e as filhas; tal contato não é somente focado no futuro do jovem; elas monitoram com maior incisão as atividades dos filhos e filhas, buscando discipliná-los; as mães também se engajam nos interesses que os adolescentes têm para si mesmos; finalmente, as mães envolvem-se nas experiências de vida de seus filhos, não somente como autoridades, mas como confidentes, construindo com eles uma relação de empatia. Porém o relacionamento entre mães e adolescentes é diferente das relações que mantêm com seus amigos, e os jovens conhecem essa diferença. (Youniss \& Smollar, p. 91).

Em resumo os autores propõem que:

A descoberta deturpada do conceito de autonomia parece ser devido a uma ênfase exagerada na auto-confiança individual, auxiliada pela orientação da teoria cognitiva. Embora pareça correto que o raciocínio do adolescente é mais desenvolvido que o da criança, ele não é consequiência de uma maior individualidade. Inclusive, a oposição pode ser o caso. Adolescentes parecem conscientes de como muito de si mesmos está em dívida - naquilo que eles pensam e quem eles são - dos outros. A intenção desses compromissos não deve ser deixada de lado nas relações. Pelo contrário, o que parece ampliar o raciocínio moral dos adolescentes é uma séria busca de relacionamentos que cultivem interdependência, tanto que o auto-entendimento pode ser melhorado através do mútuo entendimento. (Youniss \& Smollar, 1985, p.170).

Os autores chamam atenção para o fato de que, segundo eles, o crescimento do self não precisa ser incompatível com o desenvolvimento das relações. Os dois podem ser concebidos como simultâneos e interconectados. Assim, essa pesquisa, faz parte do conjunto de estudos sobre a relação pais e adolescentes que não acreditam no conflito como premissa.

Esse também é o caso da pesquisa de Smetana (1989), que investigando o raciocínio do adolescente e da família sobre as questões do conflito na relação pais e filhos, apresenta resultados surpreendentes que contradizem as observações do senso-comum e de algumas abordagens teóricas, como por exemplo a psicanalítica.

Para a autora, os conflitos surgem entre os pais e os adolescentes porque os primeiros costumam avaliar e agir diante dessas situações em termos de convenções sociais, ou seja, corrigem os seus filhos em termos de certo ou errado, isto é, daquilo que é apropriado ou não para a idade deles; já os adolescentes avaliam as mesmas situações, seguindo o domínio pessoal, pois sentem-se no direito de escolher o que fazer, ou seja, pensam que podem fazer suas escolhas pessoais. (Smollar, 1989, 1066)

Outras conclusões interessantes de seu trabalho dizem respeito ao fato de que: há um aumento das discussões entre pais e adolescentes, nos primeiros anos da adolescência, e que, 
depois há uma tendência para a diminuição dos conflitos, no final da mesma.

Segundo Jimenez e Delgado (2002, p.217), para Smetana (1989), Selman (1989), Youniss e Smollar (1985), isso se dá devido ao desenvolvimento do pensamento formal que conduz o adolescente a ser mais reflexivo no início da adolescência, e, portanto, a conquista de um raciocínio abstrato amplia a tendência ao envolvimento em um maior número de conflitos com seus pais, pela constante argumentação, pela necessidade de expor os seus pontos de vista e imposição do seu modo de pensar, como mais adequado que aquele dos seus pais.

A posição piagetiana (Inhelder e Piaget,1970/1976) é exatamente essa, embora não se remetendo especificadamente à relação pais e adolescentes, mas abordando a questão do egocentrismo próprio do início da adolescência, quando o jovem constrói opiniões abstratas sobre todos os assuntos, inclusive as práticas paternas, e quer impor suas teorias e hipóteses a todos, permanecendo centrado em suas idealizações e buscando adaptar o mundo à sua forma de vê-lo.

Laursen, Coy e Collins (1998), realizaram uma meta-análise sobre a temática do conflito na relação pais e filhos. Nesse trabalho, definiram que o problema da ampliação do conflito no início da puberdade está mais relacionado à discrepância entre o que os pais esperam de seus filhos e o seu comportamento real. Outra conclusão comum às pesquisas sobre o tema, diz respeito à questão da intensidade do sofrimento em relação a tais conflitos que parece ser maior também nos anos iniciais da adolescência.

A pesquisa de Smetana (1989) ainda aponta para o fato de que o raciocínio convencional está relacionado ao sexo e a idade. Portanto, os meninos mais do que as meninas, e, os meninos mais velhos mais que os pré-adolescentes tendem a assumir mais facilmente a perspectiva dos pais. Por outro lado, questões relativas às relações interpessoais como, por exemplo, brigas com os irmãos são tratadas por adolescentes e familiares como de domínio moral. (Smetana, 1989, p.67).

Em outra pesquisa, Smetana e Asquith (1994), investigaram as concepções de pais e adolescentes a respeito do conceito de autoridade parental e autonomia pessoal. A pesquisa teve como referencial a Teoria do Domínio Social de Turiel (1983). Os resultados da pesquisa revelaram que, diferentes formas de autoridade parental coexistem durante a adolescência. Por um lado, pais e adolescentes concordam que é da jurisdição da autoridade parental regular as questões do âmbito moral e convencional. Por outro lado as opiniões divergem a respeito de questões que se remetem ao âmbito pessoal (escolha das roupas), ao domínio multifacetado (meninos usar brincos, limpar o quarto), e ao domínio dos amigos (ver um amigo que os pais 
não gostam, quando começar a namorar). As fronteiras desses domínios são divergentes para pais e filhos, e por isso, a autoridade parental não é legitimada pelos adolescentes para esses domínios, causando conflitos especialmente no início da adolescência (Smetana e Asquith, 1994, p.1159).

Tanto Smetana (1989), quanto Youniss e Ketterlinuns (1987) investigaram questões relativas à variável gênero em suas pesquisas. Porém, as pesquisas de Gilligan (1982) são precursoras da importância de se considerar essa variável, pois segundo ela, a questão do gênero não é somente uma variável dependente das pesquisas, mas possui outra conotação.

Gilligan (1982) criou um sério "desconforto acadêmico" ao afirmar que a psicologia considera os comportamentos masculinos como objeto de padrões e normas e, portanto, os comportamentos femininos quando não coerentes àqueles primeiros, são considerados de maneira preconceituosa enquanto inferiores às respostas masculinas. "Assim, quando as mulheres não se ajustam aos padrões da expectativa psicológica, as conclusões têm sido, em geral, que alguma coisa está errada com as mulheres”. (Gilligan, 1982, 24).

Em 1977, considerou os resultados das pesquisas de Kohlberg como mal orientados, devido ao foco na justiça e na lei. Propôs que a mulher teria uma ética especial, fundamentada não na justiça e na lei, mas no cuidado. Portanto, a autora elaborou dois conceitos afirmando que essa visão comum da psicologia moral, diz respeito à moralidade ou ética da justiça, porém a forma da mulher ou da adolescente avaliar, julgar e agir em relação ao domínio moral está completamente influenciado por um sentimento de compaixão e cuidado para com o outro.

A ética do cuidado foi explicada pela autora através de um conceito básico da sua teoria: o conceito de conexão. Baseada nos estudos de Nancy Chodorow (1974, citada por Gilligan, 1982, p.18), a autora explicou que as relações que as meninas (mesmo sexo da mãe) mantêm com suas mães são de conexão, enquanto que os meninos tendem a se separarem precocemente do convívio materno. Portanto, os meninos têm uma convivência menos dependente, brincando mais nas ruas, relacionando-se com um número maior e mais heterogêneo de pessoas de diferentes gêneros e idades, enquanto as meninas permanecem mais aproximadas de suas genitoras, imitando-as e mantendo uma relação pautada na intimidade, no cuidado e na dependência. Nas suas próprias palavras:

Para os meninos e homens, separação e individuação acham-se criticamente vinculadas à identidade de gênero, visto que a separação da mãe é essencial para o desenvolvimento da masculinidade. Para meninas e mulheres, questões de feminilidade ou identidade feminina não dependem da consecução da separação da 
mãe ou do progresso da individuação. Uma vez que a masculinidade define-se através da separação enquanto que a feminilidade define-se através do apego, a identidade de gênero masculino é ameaçada pela intimidade, ao passo que a identidade de gênero feminino é ameaçada pela separação. (Gilligan, 1982, p.19)

Portanto, a ética do cuidado é fruto das interações sociais que se estabelecem, bem como de questões naturais aos gêneros, portanto inatas também. A proposta da autora é a da compreensão de dois tipos de desenvolvimento psicológicos paralelos, e que resultam em "vozes diferentes", conforme ela mesma anota, ou seja, concorda com a justiça enquanto objeto da moral, mas não somente a justiça, pois acrescenta a ela o cuidado.

Naquilo que diz respeito às interações entre pais e filhos, Gilligan (1988/2001) afirma a importância de se considerar as questões relacionadas ao conceito de conexão, portanto, critica o conceito de autonomia em Piaget (1932) fundamentado, segundo ela essencialmente na cooperação entre pares. Para a autora a autonomia não depende somente da genuína experiência da cooperação, mas também dessa experiência da conexão com os pais. (Gilligan, 1988/2001, p.134).

A presente pesquisa também investigou o gênero (pais e mães) como uma variável dependente, e buscou diferenças significativas estatisticamente em relação às concepções educativas paternas e maternas. Esses resultados serão apresentados no oitavo capítulo desse texto.

Todas as pesquisas até aqui apresentadas afirmaram a importância do contexto interativo familiar para o desenvolvimento da autonomia do adolescente. Lopes aponta para uma necessidade ou direção possível para as pesquisas na área do desenvolvimento moral: "a construção de um modelo evolutivo de cooperação e autonomia no contexto das relações familiares".

A pesquisa que aqui se apresenta, por fundamentar-se na teoria Piagetiana (1932), que considera a cooperação como caminho possível e necessário para a construção da autonomia, tem como principal objetivo construir e validar um instrumento que possa investigar essa dimensão da cooperação no conceito e na intervenção de pais de adolescentes, entendida por Piaget como respeito mútuo, obediência a princípios de justiça comumente acordados pela reciprocidade entre iguais.

O capítulo seguinte apresenta os construtos que vão compor esse instrumento: Escala de Concepções Educativas. Os itens que representam cada construto (obediência, respeito, justiça e autonomia) são apresentados e justificados pela teoria do juízo moral de Jean Piaget (1932). 


\title{
4- ADOLESCÊNCIA E A CONSTRUÇÃO DA AUTONOMIA MORAL
}

\begin{abstract}
A idéia que defendemos é bem mais concreta: trata-se apenas de criar em cada pessoa um método de compreensão e de reciprocidade. Que cada um, sem abandonar seu ponto de vista, e sem procurar suprimir suas crenças e seus sentimentos, que fazem dele um homem de carne e osso, vinculado a uma porção bem delimitada e bem viva do universo, aprenda a se situar no conjunto dos outros homens.[...] Precisamos de uma atitude intelectual e moral nova, feita de compreensão e de cooperação, que sem abandonar o relativo atinja a objetividade pelo estabelecimento de relações entre pontos de vista eles mesmos particulares. (Piaget, 1934a/1998, p.135-136)
\end{abstract}

O título do capítulo apresenta conceitos a serem definidos: construção, moral, autonomia e adolescência. Ao se falar em construção da autonomia moral, faz-se implicitamente a opção pela teoria piagetiana do juízo moral. Por quê? Porque "construção" é a concepção básica do seu modelo epistemológico. Para o autor construção é autoorganização, e, tal conceito explicará todo o processo do desenvolvimento moral do indivíduo, assim como, responderá as perguntas que nortearam o desenvolvimento de sua teoria psicogenética: como se dá o conhecimento e como o conhecimento se transforma ao longo da vida do indivíduo.

Segundo La Taille (1994): "Nunca é demais lembrar que Piaget dedicou apenas um livro $^{11}$ à questão do desenvolvimento moral e que, portanto, para entender suas idéias a respeito da moralidade é preciso situá-las no contexto maior de sua epistemologia genética". Conforme o autor, quatro eixos comuns da teoria piagetiana são aplicáveis a estruturas da inteligência, ao conhecimento físico, à memória, as imagens mentais, à moral, etc: entre eles, sujeito epistêmico, gênese, interação e, a construção, cujo conceito deseja-se esclarecer aqui. (La Taille, 2006, p.14)

Portanto, para Piaget a mente é capaz de se auto-regular, ou seja, se auto-organizar, construindo estruturas. Logo o conhecimento não é inato e tampouco é fruto da imposição do ambiente sobre o sujeito. A construção é fruto do processo de assimilação e acomodação do sujeito que, interagindo com os objetos do conhecimento, como é o caso da moral, retira elementos do objeto e os integra às suas estruturas (assimilação), assim como transforma a estrutura para dar conta das novidades do objeto assimilado (acomodação). (Piaget, 1936/1970, p. 17-18).

${ }^{11}$ Piaget, J.(1932/1994). O juízo moral na criança. E. Leonardon, Trad. (2a ed.). São Paulo: Summus 
Por isso, Piaget investigou o desenvolvimento humano através do estudo e observação de bebês, crianças e adolescentes, uma vez que, este estudo foi o mais apropriado para as suas investigações a respeito da gênese do conhecimento e para demonstrar empiricamente e explicar o seu modelo teórico de construção da inteligência.

Tal modelo teórico, explica o desenvolvimento da inteligência, tendo como conteúdo básico, a ação do sujeito que interage com os objetos, construindo a partir dessas ações, formas e ou estruturas de inteligência, que lhe permitem cada vez mais, adaptar-se ao mundo em que vive, pois para Piaget, podemos definir uma interdependência entre a relação sujeito e objeto:

O sujeito é, portanto, nesta perspectiva, ativo e construtor de sua inteligência a cada encontro que realiza com os objetos que visa assimilar, seja esta ação sobre o objeto exclusivamente física (nos primeiros meses de vida), simbólica (a partir da interiorização das ações) ou lógica (porque encaixada num sistema de ações coordenadas e reversíveis). (De Souza, 2002, p.57)

Quem é o sujeito de Piaget? La Taille (2006, p.15) responde: "O chamado 'sujeito epistêmico', ou sujeito do conhecimento, estudado por Piaget, é aquele que, se ele tiver razão, encontra-se em todos nós quando elaboramos conhecimentos sobre o mundo e sobre nós mesmos". Portanto, Piaget se interessou pelo que seria comum ao desenvolvimento em todas as pessoas, o mesmo valendo para os seus estudos sobre o sujeito moral.

Segundo Piaget, o sujeito tem a possibilidade de reorganizar as estruturas de inteligência conforme surgem solicitações do meio, e, a partir de tais novas solicitações, o sujeito vivencia constantes mecanismos de assimilação de novos objetos a esquemas já existentes, e mecanismos de ampliação do conhecimento denominados acomodação. O mecanismo responsável pelas sucessivas assimilações e acomodações é chamado por Piaget de equilibração (conceito central da sua teoria construtivista do conhecimento).

Assim, quando as estruturas que o sujeito já construiu não lhe permitem assimilar um novo objeto de conhecimento, isto é, determinado objeto é "resistente", isto provoca nele uma perturbação e o desequilíbrio é desencadeado. Segundo Piaget, "uma estrutura estará em equilíbrio na medida em que o indivíduo é, suficientemente, ativo para poder opor a todas as perturbações e compensações exteriores". (1964/1986, p.140).

Logo, a mesma interdependência entre sujeito e objeto é apontada na teoria piagetiana na relação entre estrutura e gênese, uma vez que para ele "toda gênese parte de uma estrutura e chega a uma estrutura" (1964/1986, p.136).

Para o autor, o recém-nascido traz consigo condições de vir a se tornar inteligente, e 
conforme age sobre o mundo, constrói estruturas que lhe permitem cada vez mais se adaptar às novas situações, de maneira a construir estágios sucessivos de desenvolvimento: "De fato, nenhum comportamento, nem mesmo quando é novo para o indivíduo, constitui um início absoluto. Está sempre apoiado em esquemas anteriores e, portanto, leva à assimilação de novos elementos a estruturas já construídas (inatas, como os reflexos, ou previamente adquiridas)". (Piaget, 1975, p.77).

O autor afirma que gênese é a passagem de um estado anterior para um ulterior. (Piaget, 1964/1986, p. 139). Para o autor uma estrutura de inteligência é ponto de partida (gênese, portanto), para uma estrutura mais complexa, sendo que, há "estrutura quando os elementos são reunidos em uma totalidade que apresenta certas propriedades como totalidade e as propriedades dos elementos dependem dessa totalidade" (Battro, 1987, p.99). As estruturas da inteligência são características de determinada fase do desenvolvimento cognitivo. Portanto, para ele, os estágios têm caráter sucessivo (e não cronológico) e integrativo, porque cada um deles é necessário para a formação do seguinte.

Nas palavras de La Taille (2006, p.15): “As estruturas lógicas e o conhecimento físico começam a ser elaborados desde o nascimento e o que faz a diferença entre uma criança e um adulto não é a presença ou ausência de certas capacidades, mas sim o nível de sofisticação de cada uma delas".

Finalmente a mesma interdependência apontada pelo interacionismo piagetiano, entre sujeito e objeto, assimilação e acomodação, estrutura e gênese, se manifesta também, na teoria psicogenética, entre os aspectos afetivos e cognitivos do desenvolvimento psicológico do ser humano. Tal fato é ignorado por muitos críticos de Piaget, que o acusam de intelectualista, afirmando que ele desconsiderava a importância da afetividade para a construção do conhecimento. Segundo De Souza (2002), Piaget atribuí qualidades às ações do sujeito conhecedor: “...são estruturadas pela inteligência e mobilizadas pela afetividade (energia impulsionadora da ação)". (De Souza, 2002, p.58).

Essa interdependência entre o desenvolvimento afetivo e cognitivo é de extrema importância para a construção da autonomia moral, pois, segundo o autor, o desenvolvimento das estruturas cognitivas e os sistemas afetivos são contemporâneos no desenvolvimento, e há uma correspondência entre os estágios do desenvolvimento cognitivo e afetivo, sendo que a construção dos sentimentos morais é fruto da intersecção desses dois desenvolvimentos. (Piaget, 1954/1994, p.200).

Porém, antes que se apresentem as idéias de Piaget sobre a construção da autonomia moral do adolescente, fruto do desenvolvimento afetivo, cognitivo e social, faz-se necessário, 
discutir o conceito de moral para o autor, e, ainda, antes de fazê-lo é importante concluir que, portanto, para Piaget, o desenvolvimento moral é visto como um processo de construção, que necessita da interação social, ou seja, a moral se desenvolve em contextos sociais:

São as relações que se constituem entre a criança e o adulto e entre ela e seus semelhantes que a levarão a tomar consciência do dever e a colocar acima de seu eu essa realidade normativa na qual a moral consiste. Não há, portanto, moral sem sua educação moral, "educação" no sentido amplo do termo, que se sobrepõe à constituição inata do indivíduo. (Piaget, 1930/1994, p.3).

A partir das palavras do autor, já se tem definido o significado de moral. A teoria piagetiana tem uma abordagem deontológica, isto é, o tema da moral diz respeito aos deveres, portanto, responde a pergunta: como devo agir, ou o que devo fazer. Nas palavras do próprio autor: "toda moral consiste num sistema de regras, e a essência de toda moralidade dever ser procurada no respeito que o indivíduo adquire por essas regras." (Piaget, 1932/1994, p.23).

La Taille afirma que:

Tal definição é clássica, corresponde à tradição judaico-cristã, à concepção deontológica de Kant, e também ao que hoje, o senso comum define como moral, com grande peso associado às proibições, "aos limites", para empregar uma metáfora consagrada. (La Taille, 2002, p.16)

A teoria do juízo moral de Piaget, a partir de sua definição, ainda é caracterizada por La Taille como uma teoria psicológica que enfatiza a dimensão intelectual da moralidade, ou seja, o 'saber fazer', em detrimento ao 'querer fazer', dimensão sobre a qual se debruçam as teorias psicológicas da moralidade que enfatizam a abordagem afetiva. (La Taille, 2008, p.13)

A partir dessa classificação, pode-se pensar em teorias representativas da moralidade que afirmam a importância da razão e a possível autonomia dos seres humanos, sendo a teoria piagetiana uma delas, e a teoria kohlberguiana, a sua outra possibilidade. Ambas tendem a “explicar a moralidade pela razão, afirmar a virtual autonomia dos indivíduos e sustentar o universalismo moral definindo-o por meio dos ideais de justiça”. (La Taille, 2006, p.22)

Kohlberg foi leitor de Piaget: investigou a moralidade no sujeito psicológico e não no sujeito moral como Piaget, e construiu a partir de suas investigações, utilizando especialmente o Dilema de $\mathrm{Heinz}^{12}$ (o dilema mais famoso dos estudos de moralidade), uma teoria interpretada por muitos como um aperfeiçoamento da teoria de Piaget, por ter construído os estágios da evolução da autonomia. (Kohlberg, 1981, 1984, 1987).

\footnotetext{
${ }^{12}$ Esse dilema foi apresentado nesse texto no terceiro capítulo, página 60.
} 
Será apresentado a seguir um resumo desses estágios, exatamente porque os estágios, são fruto de investigações junto a adolescentes e porque eles amplificam o conceito de autonomia, explicando a sua construção a partir da distinção de três níveis de evolução da moralidade, que são subdivididos em sub-estágios reciprocamente, de ordem e sucessão invariáveis no desenvolvimento, e cujos modos de pensar são distintos, portanto apresentam estruturas qualitativamente diferentes:

1- Pré-convencional: este é o nível em que o sujeito não é sensibilizado pelas regras sociais; vive um egocentrismo, no qual a incapacidade de perceber o ponto de vista dos outros e a necessidade de satisfação dos próprios interesses, o conduzem a uma moral heterônoma. Tal nível se distingue em dois estágios:

- Estágio I - Orientação para a punição e obediência: as respostas do sujeito revelam que ele obedece às leis por medo da punição, ou seja, tem medo daquilo que pode the acontecer caso não cumpra as regras, sendo que a autoridade se confunde com o próprio eu do sujeito;

- Estágio II - Hedonismo instrumental relativista: é caracterizado pelo sujeito que cumpre as regras para atingir a um interesse próprio, em um mundo onde cada pessoa busca os seus próprios interesses; há referência entre duas pessoas (indício dos primeiros conflitos interpessoais), mas não alcança o grupo;

2- Convencional: neste nível, as regras se prestam à manutenção da sociedade e desta forma são seguidas pelo sujeito para que se preservem em si as expectativas da família, da nação. A sociedade, portanto, está acima do próprio homem, para tal nível de julgamento moral. Ele também é composto de dois diferentes estágios:

- Estágio III - Moralidade do bom garoto, de aprovação social e relações interpessoais: este estágio é composto por pessoas que agem de acordo com as expectativas do grupo social a que pertencem. Portanto, esforçam-se para cumprir o papel do que julgam ser "boa pessoa". Fica registrada neste estágio, a idéia do estereótipo social, sendo o mais importante para os sujeitos desse grupo, serem coerentes com o discurso de bem-estar ético da humanidade, sendo essa a orientação do "bom menino", "boa menina”.

- Estágio IV - Orientação para a lei e ordem: os sujeitos deste estágio consideram a moral enquanto mantenedora do sistema social. Portanto, as regras devem ser cumpridas em prol do bem estar social, que define os 
papéis, as leis, o compromisso de cada um, e funcionam também como um controlador coletivo da consciência individual, trata-se da moralidade de manutenção da ordem social.

3- Pós-convencional: a primordial característica deste nível é a regulação dos sujeitos por princípios. Independentemente do grupo social ou das pessoas com as quais se convive, o julgamento moral é norteado por valores e princípios morais que independem da autoridade, da situação vivenciada, ou da relação do sujeito com as pessoas. Trata-se dos dois estágios mais elevados, segundo Kohlberg, e que, portanto, somente são atingidos por uma minoria de pessoas.

- Estágio V - Orientação para o contrato social: neste estágio as respostas dos sujeitos já revelam uma preocupação maior com as regras enquanto contratos sociais, dos quais os indivíduos participam espontaneamente, uma vez que tais regras se remetem ao respeito, ao bem estar de cada pessoa. Já se observa neste estágio uma prioridade do bem estar de cada um sobre o sistema social, portanto, a orientação de contrato social.

- Estágio VI - Princípios universais de consciência: segundo Kohlberg, este é um estágio que raríssimas pessoas alcançam. Nele, o homem é a razão e o bem estar da sociedade. Os princípios universais de justiça são adotados como um compromisso primordial, independentemente das leis sociais. A moral tem um fim em si mesma e no compromisso da manutenção da vida e da dignidade humana, também denominada moralidade de princípios individuais da consciência.

Portanto, as teorias do juízo moral de Kohlberg, assim como a teoria de Piaget, são representativas do grupo de teorias do "saber fazer", apontadas anteriormente, e assim definidas, por enfatizarem a dimensão racional da moralidade.

O outro grupo de teorias da moralidade, ou seja, as que abordam a questão do querer moral, podem ser identificadas por: "explicar a moralidade pela afetividade, afirmar a incontornável heteronomia dos indivíduos, e não definir um conteúdo para a moral sustentando o relativismo antropológico". (La Taille, 2006, p.22)

São teorias representativas dessa abordagem, a teoria psicanalítica de Freud (1923/2006) e a teoria sociológica de Durkheim(1974). Não se pretende prolongar as explicações das teorias de Kohlberg, Freud e Durkheim, porque não são elas eleitas para tratar da educação moral dos adolescentes no presente trabalho. Todavia, rapidamente pode-se tecer um quadro 
comparativo das mesmas teorias para que se possa categorizar a teoria piagetiana naquilo que corresponde o estado da arte da questão da moralidade.

Com relação à teoria de Freud (1923/2006) sobre a moralidade, pode-se apontar que, assim como a teoria piagetiana, tem o dever como objeto de investigação, do mesmo modo que a teoria de Durkheim (1974) também o terá. Porém, no caso da teoria Freudiana, e dessa segunda (teoria de Durkheim), o conteúdo da moral é aberto, ou seja, depende da cultura ou grupo social no qual o sujeito está inserido e, dessa forma, nesse aspecto, ambas são incompatíveis com as teorias Piagetiana e Kohlberguiana, que reconhecem o universalismo moral psicológico.

Freud (1929/1971) explicará a introjeção da moralidade a partir da instância psíquica do superego, cuja função é regular a consciência, a partir dos valores identificados pelas crianças em seus pais, a partir do Complexo de Édipo. La Taille (2008, p.17) comentando a respeito da diferença do entendimento da moralidade para a psicanálise e para a teoria piagetiana, afirma que, no caso da psicanálise, a moral é regulada pela instância psíquica denominada superego e que, o superego nasce de uma disputa pelo objeto amado. Assim, do amor e do desejo frustrados (que o menino sente pela mãe, e a menina pelo pai), surge uma atitude prudente da criança edipiana que reconhece o poder do mais velho e a conduz a identificação e introjeção dos valores morais.

Por outro lado, na moral piagetiana há uma submissão voluntária da criança aos seus pais, por reconhecer neles a figura da autoridade como fonte do sentimento de dever ou obrigação. No caso do adolescente, um processo de equilibração majorante pautado na cooperação deve conduzi-lo a superação da autoridade encaminhando-o para a autonomia. Assim, na psicanálise a moral é fruto de uma disputa pelo objeto amado, ou seja:

[...] não se trata de relação de autoridade, mas de poder, pelos menos se aceitarmos a definição de autoridade de Hannah Arendt. A obediência é vista como prudência, e não como submissão voluntária a figuras de autoridade, segundo a interpretação de Piaget da moral autônoma infantil. (La Taille, 2008, p.18)

Com relação à teoria de Durkheim (1974), o mesmo sentimento de dever ou obrigatoriedade, é chamado pelo autor de sentimento do sagrado. Logo, a regra se impõe ao indivíduo pelo "ser coletivo", ou seja, pela "sociedade", daí a moral ser relativista e antropológica, ou seja, depende da cultura em que a criança está inserida. Segundo Piaget (1930/1994, p.11), três elementos constituem a moral de Drkheim: primeiro, as crianças devem ser habituadas a respeitar as regras coletivas, e, ensinadas a cultivar a solidariedade; 
segundo, a regra se impõe ao indivíduo sob a pressão dos grupos; e terceiro, a autonomia significa não libertar-se dessa pressão mas compreender sua necessidade e aceitá-la livremente. Portanto, a autoridade está presente nessa teoria que, assim como a de Freud (1929/1971), implicará numa moral heterônoma, porque dependente das imposições de regras alheias e próprias de cada sociedade.

Ambas enfatizam, portanto, o aspecto afetivo da moral, como já se anunciou, anteriormente, ou seja, dependem de um "querer fazer" do sujeito, no caso da psicanálise, a moral é a expressão do superego que regula a consciência do indivíduo, e para a sociologia de Durkheim, a moral também é a regulação do sujeito que tem que se adaptar a um sistema pronto, o da sociedade em que vive.

Importa que se sublinhe nesse momento que, há algo em comum em todas as expressões da moralidade, trata-se do sentimento de obrigatoriedade. Para La Taille (2006, p. 31), o sentimento de obrigatoriedade é uma realidade comum, sejam quais forem os deveres: "Portanto, a exigência social do cumprimento do dever corresponde à 'forma', que pode receber vários conteúdos (o que é dever aqui não o é ali)".

Em se falando em deveres, Piaget, escreveu um texto no qual se remete aos procedimentos da educação moral. Para o autor, o fim de toda a educação deve ser a formação moral do indivíduo, formação essa que deve ajudá-lo a construir o pleno desenvolvimento da personalidade, com um raciocínio lógico pronto e uma consciência moral desperta. (Piaget, 1948/2000, p. 53). Para o autor, os deveres da educação moral são assim definidos:

No que se concerne ao fim da educação moral, podemos, pois, por uma legítima abstração, considerar que é o de constituir personalidades autônomas aptas à cooperação; se desejarmos, ao contrário, fazer da criança um ser submisso durante toda a sua existência à coação exterior, qualquer que seja ela, será suficiente todo o contrário do que dissemos. (1930/1994, p.9)

Portanto, refletir sobre os estudos de Piaget a respeito da construção da autonomia moral do adolescente, implica em pensar uma educação moral que conduza verdadeiramente a formação de pessoas de bem, isto é pessoas cujos deveres morais representem-nas enquanto as pessoas que são e a vida que levam. (La Taille, 2006, p.61). A adolescência é exatamente o período de construção da personalidade, e para Inhelder e Piaget (1970/1976), construir-se como pessoa, ou personalidade implica em ser autônomo. 
Os dois últimos termos ainda não definidos do título, são exatamente, adolescência e autonomia. A autonomia deve ser a principal conquista da adolescência, e a educação moral deve providenciar reais oportunidades para essa construção.

Para Piaget (1948/2000, p.48), os dois problemas essenciais da educação moral são:

1- $\quad$ assegurar a descentralização: a pessoa ser capaz de situar o seu eu na verdadeira perspectiva em relação aos outros;

2- estabelecer a disciplina autônoma: inserida num sistema de reciprocidades;

Partindo do segundo problema, a proposta é de compreender o conceito de autonomia para Piaget e a sua relação com a adolescência. Quando do início desse capítulo, ao se remeter a teoria psicogenética e da dialética da construção presente entre sujeito e objeto, estrutura e gênese, desenvolvimento cognitivo e afetivo, observou-se que para o autor o desenvolvimento é fruto de um processo integrativo, no qual:

destaca o caráter teleonômico de seu modelo, descrevendo a inteligência em estágios sucessivos que rumam em direção ao ápice das operações formais de pensamento, as quais dão conta da multiplicidade de interações do sujeito com o mundo físico e social em seus aspectos reais e virtuais. (De Souza, 2002, p.29)

A sua visão construtivista da inteligência como adaptação é freqüentemente retomada por ele em suas obras, sendo que, ao se remeter "às inaugurações das atividades novas" possíveis aos adolescentes, o autor, delineia uma crítica a duas das teorias da adolescência, também discutidas anteriormente no segundo capítulo. Conforme suas palavras:

Ora, a psicologia clínica e, sobretudo, a psicanálise, cuja moda domina atualmente, muitas vezes não vêm na afetividade senão um jogo de repetições ou analogias com o passado (reedição do Édipo ou do narcisismo etc). Ana Freud e Erick Erickson insistiram fartamente nas "identificações sucessivas", em que os mais velhos fazem o papel de modelos e liberam escolhas infantis, com o perigo, aliás, de uma "difusão de identidade" (Erickson), mas o que pouco viram foi o papel da autonomia concreta adquirida durante a segunda infância, e sobretudo, o papel das construções cognitivas que permitem a antecipação do futuro e o franquear dos valores novos. (Piaget e Inhelder, 1966/1978, p.127).

Para o autor a construção da autonomia moral, define-se juntamente com a adolescência, quando o jovem constrói a possibilidade cognitiva de raciocinar por hipóteses, a partir da construção da lógica da combinatória e das preposições que garante ao adolescente a possibilidade da abstração do pensamento e reflexão.

O estágio formal, como é chamado por Piaget, o estágio de desenvolvimento cognitivo 
que deve ser alcançado pelo adolescente, é aquele anunciado pela possibilidade de um raciocínio abstrato. Segundo Piaget (1972/2008, p. 42): “ a principal novidade deste período é a capacidade de raciocinar em termos de hipóteses afirmadas verbalmente e não mais meramente em termos de objetos concretos e suas manipulações".

De início, a assimilação do pensamento formal se dá de forma egocêntrica, como ocorre com qualquer nova capacidade da vida mental, para mais tarde chegar ao equilíbrio através de uma acomodação garantida pela nova estrutura. Assim, essa derradeira forma de egocentrismo se caracteriza pela crença na onipotência da reflexão. Nas palavras de Piaget se tem a definição do conceito de egocentrismo: “o egocentrismo é o estado de indiferenciação que ignora a multiplicidade das perspectivas, enquanto que a objetividade supõe, ao mesmo tempo, uma diferenciação e uma coordenação dos pontos de vista". (Inhelder e Piaget, 1970/1976, p. 256).

E ainda conforme as palavras do autor sobre o egocentrismo da adolescência:

As operações formais fornecem ao pensamento um novo poder, que consiste em destacá-lo e libertá-lo do real, permitindo-lhe, assim construir, a seu modo, as reflexões e teorias. A inteligência formal marca, então, a libertação do pensamento e não é de admirar que este use e abuse, no começo, do poder imprevisto que lhe é conferido. Esta é uma novidade essencial que opõe a adolescência à infância: a livre reflexão espontânea. (Jean Piaget, 1964/1986, p.64).

A capacidade cognitiva providenciada pela lógica proposicional e pelo raciocínio hipotético dedutivo permite ao indivíduo inclusive, tomar como conteúdo dos seus pensamentos, os seus próprios sentimentos. (De Souza, 2003). Assim, o adolescente é chamado nesse período de idealizador, questão essa que explica parcialmente as crises do mesmo quanto à sua inserção no mundo adulto.

O equilíbrio será alcançado na medida em que a reflexão compreender que sua função não se encontra em contradizer a realidade, mas em compreender a experiência e se adiantar a ela, envolvendo, além das experiências do mundo real, as construções com base na dedução racional e o conhecimento da vida interior. Conforme as palavras de Piaget e Inhelder (1966/1978, p.126):

A diferença essencial entre o pensamento formal e as operações concretas é que estas estão centradas no real, ao passo que aquele atinge as transformações possíveis e só assimila o real em função desses desenvolvimentos imaginados ou deduzidos. Ora, tal mudança de perspectiva é tão fundamental do ponto de vista afetivo quanto do ponto de vista cognitivo, pois o mundo dos valores também pode permanecer aquém 
das fronteiras da realidade concreta e perceptível ou, ao contrário, abrir-se para todas as possibilidades interindividuais ou sociais.

O adolescente necessita adaptar-se a essa realidade do mundo social e não o contrário, para tanto, precisa superar o egocentrismo próprio dessa fase. Conforme De Souza (2003, p. 67): “O egocentrismo na adolescência dificulta a aplicação da potência cognitiva à realidade do mundo social, o que será superado quando o jovem passar de reformador a realizador."

A convivência social ampliada pela adolescência, com a tendência dos jovens de se reunirem com grupos e jovens é um fator importantíssimo que auxiliará no processo de descentração ${ }^{13}$. Conforme argumenta Inhelder e Piaget (1970/1976, p.257): “Ora, essa vida social é origem da descentração intelectual e não apenas moral, é principalmente nas discussões com os colegas que o criador de teorias frequentemente descobre, pela crítica dos outros, a fragilidade das suas".

A evolução da moralidade depende, dessa forma, das relações que se estabelecem com o outro. Quando o sujeito constrói o respeito mútuo e os princípios de justiça como dever, e as regras são fundamentadas em tais princípios e cumpridas por opção racional de tais sujeitos, outro nível de desenvolvimento moral é atingido, a autonomia, também denominada por Piaget (1932/94) de moral do bem, já que a noção do bem, segundo ele, diz respeito ao bem estar comum: "constitui talvez a última tomada de consciência do que é condição primeira da vida moral: a necessidade de afeição recíproca” (p.141).

Portanto, para Piaget a própria tomada de consciência de si é estimulada pela cooperação, na medida em que, é fruto da conduta social e não da psicologia individual, pois as próprias opiniões, sentimentos e vontades, se constituem, modificam-se e se constroem na oposição, nos conflitos e na compreensão mútua. Conforme suas próprias palavras: "A formação da personalidade, no duplo sentido de uma tomada de consciência do eu e de um esforço para situar esse eu no conjunto das outras perspectivas é, pois, o primeiro efeito da cooperação". (Piaget, citado por Xypas, 1997, p.106).

A autonomia moral é produto das relações de cooperação que propiciam a descentração e a troca de pontos de vista.

Sendo a cooperação fonte de personalidade, na mesma ocasião as regras deixam de ser exteriores. Tornam-se, ao mesmo tempo, fatores e produtos da personalidade,

\footnotetext{
${ }^{13}$ La Taille (1994, p.19), no prefácio da edição brasileira do livro O Juízo Moral na Criança (1932), explicita o significado do conceito de descentração para Piaget: "Descentração, ou seja, superação do egocentrismo, significa também tomada de consciência de si. Egocentrismo significa justamente, falta de tal consciência".
} 
segundo um processo circular tão freqüente no decorrer do desenvolvimento mental. A autonomia sucede assim à heteronomia. (Piaget, 1932/1994, p. 82)

\section{Para Piaget,}

a adolescência constitui um momento de virada decisivo: aquele em que o sujeito rejeita ou pelo menos revê tudo o que lhe inculcaram, de modo a construir em si uma representação das coisas e um projeto de vida pessoais. Enquanto que o dever dos iniciados primitivos é submeter-se a uma verdade pronta, o primeiro dever do adolescente moderno é insurgir-se contra toda verdade imposta e construir para si seu próprio ideal intelectual e moral tão livremente quanto possa". (Piaget, 1947/1998, p.164)

Assim, quando Piaget $(1954 / 1994)^{14}$ estabelece o quadro de correspondência entre o desenvolvimento afetivo e cognitivo, culminando com o desenvolvimento moral do indivíduo, admite, portanto, que as crianças devam ultrapassar a moral da obediência a que ele denomina heteronomia, a fim de alcançarem a autonomia.

Segundo o autor, o critério da adolescência é dado pela possibilidade que se abre ao jovem de se inserir no mundo dos adultos, e por esse motivo considera os fatores sociais nessa fase ainda mais importantes que os fatores neurológicos ou individuais, pois segundo tal autor, a integração social deve ser explicada por três importantes fatores:

1- O adolescente é o indivíduo que começa a considerar-se como igual pelos adultos e julgá-los num plano de igualdade e total reciprocidade;

2- $\quad$ O adolescente é ainda um indivíduo em formação, mas que começa a pensar no futuro, isto é, em seu trabalho atual ou futuro na sociedade;

3- $\quad$ O adolescente é o indivíduo que, procurando introduzir-se e introduzir o seu trabalho atual ou futuro na sociedade dos adultos, se propõe também a reformar essa sociedade. (Inhelder e Piaget, 1970/1976, p.252, grifo nosso)

Assim como essa possibilidade de socialização do adolescente é garantida pelo desenvolvimento das operações formais, duas transformações afetivas também são apontadas como necessárias para que o adolescente de fato integre-se ao mundo adulto: "sentimentos relativos a idéias, que se acrescentam aos sentimentos entre as pessoas, e a formação de personalidades, caracterizadas pelo papel social e a escala de valores que se atribuem." (Inhelder e Piaget, 1970/1976, p.258).

Com relação aos aspectos afetivos, portanto, o que muda nos sentimentos para que eles

\footnotetext{
${ }^{14} \mathrm{O}$ curso sobre as Relações entre afetividade e inteligência no desenvolvimento mental da criança permitiu ao autor explicitar suas reflexões sobre afetividade, a socialização, a vontade e a moral. [...] o "curso da Sorbonne" como é chamado, gerou um texto fundamentado nas notas tomadas durante o curso de 1953-54, retocadas por Piaget. (De Souza, 2003, p.56).
} 
possam ser considerados sentimentos morais, é a presença da força de vontade como reguladora das ações. A vontade decidirá entre duas tendências para buscar a resolução de um conflito. Segundo Piaget, “a vontade é uma regulação em segundo grau, uma regulação das regulações, da mesma maneira que no plano intelectual a operação é uma ação sobre as ações".(1954/1994, p.277). Os adolescentes necessitam construir sistemas de valores complexos fixos (conservação obrigatória), para que a força de vontade encontre nessa hierarquia, energia para cumprir os deveres e optar por uma tendência de maior magnitude (quando em situação de conflito).

Esses sentimentos morais, já conhecidos das crianças, vividos em função das relações de respeito unilateral e respeito mútuo, permanecem nos jovens e adultos, porém acrescentam-se os sentimentos ligados aos ideais ou sentimentos ideológicos, que são a grande novidade no âmbito afetivo, segundo Piaget, para a adolescência.

Percebe-se que o autor compreende a personalidade enquanto um "papel" que o sujeito desejará desempenhar na sociedade. Ele explica que para que o adolescente possa se inserir na vida social, precisa descentrar-se e subordinar a sua escala de valores ao ideal coletivo. Esse processo culmina na "organização autônoma das regras dos valores e a afirmação da vontade, com a regularização e afirmação moral das tendências" (Piaget, 1964/2002). Todos esses valores encontram-se subordinados a um sistema único e pessoal, e se referem a um plano de vida, delineado pelo adolescente.

Um plano de vida é, em primeiro lugar, uma escala de valores que colocará alguns ideais como subordinados a outros e subordinará os valores meios aos fins, considerados como permanentes. Ora, essa escala de valores é a organização afetiva correspondente à organização intelectual da obra que o recém-chegado ao universo social pretende realizar. Um plano de vida é, de outro lado, uma afirmação de autonomia, e a autonomia moral enfim inteiramente conquistada pelo adolescente, que se considera igual aos adultos, é um outro aspecto afetivo essencial da personalidade nascente que se prepara para enfrentar a vida. (Inhelder e Piaget, 1970/1976, p.260)

Definido o processo de construção da autonomia em Jean Piaget permanece a questão de que, para autor, o adolescente estudado é um sujeito epistemológico, e, portanto, são apresentadas todas as suas possibilidades de desenvolvimento, isto é, qual o caminho de evolução possível a ele. $\mathrm{O}$ autor teoriza sobre aquilo que é necessário para o jovem alcançar esse patamar de autonomia, ou seja, construir sua personalidade, inserir-se no mundo adulto, com um plano de vida, cujos ideais trarão também, algo de novo para a sociedade. 
Hoje em dia não se pode dizer que se observa esse desenvolvimento acontecendo de fato. Os filhos tendem a permanecer na casa dos pais por um período muito mais prolongado, e parece não haver uma preocupação com essa necessidade de assumir um plano de vida. Conforme comentários de La Taille, os jovens de hoje em dia, diferentemente da geração anterior não sentem vergonha de ser chamados de adolescentes aos vinte e dois, ou vinte e três anos:

Não sei se sentem até orgulho, mas o fato é que encaram com extrema naturalidade a questão: "Ainda não somos adultos". A idéia não é permanecer na adolescência em si, mas a de que eles ainda não são adultos. E creio que isso se deve ao fato de que "ser adulto" dá medo. Contudo, isso é contraditório com o desenvolvimento, que traz embutido a idéia de superação de limites, a superação de si próprio. (La Taille, 2005, p. 51).

Uma das hipóteses para esta situação está centrada na participação da educação dos pais. O tema do desafio da independência e da dependência regressiva é influenciado por muitos fatores, entre eles as questões econômicas e sociais, os problemas de ordem cultural. Entretanto, a dificuldade dos pais, salvo as devidas exceções, de permitir que os filhos adolescentes se tornem adultos é bastante comum.

Segundo Piaget, os pais são psicólogos medíocres e dificultam o processo de construção da autonomia no adolescente. Conforme suas palavras:

A pressão social não basta de nenhuma maneira para explicar a autonomia, e que em particular as pressões familiares podem ser interiorizadas sem que haja autonomia (relacionaremos esse problema com o do superego, que Freud reduzia a introjeção da autoridade parental, e da qual anteriormente já temos feito uma crítica). Enquanto a redução do respeito mútuo ao mutualismo, recordaremos somente que esse respeito não é uma reciprocidade qualquer, senão precisa e especificadamente uma reciprocidade de pontos de vista. (Piaget, 1954/1994, p.282).

Conforme se pode constatar segundo a teoria de Piaget, para que os jovens tenham a oportunidade de evoluir da heteronomia para autonomia, as relações sociais representam um fator importante, embora não único. "Para que o meio social atue realmente sobre os cérebros individuais, é preciso que estes estejam em condições de assimilar as contribuições desse meio". (Inhelder e Piaget, 1970/1976, p.251). Portanto, a convivência com a família tem uma influência importantíssima no desenrolar do desenvolvimento do adolescente, seja no aspecto cognitivo (quando suas intervenções permitem ao jovem pensar e refletir), no aspecto afetivo (que respeita e interage sem humilhações ou depreciações), e no aspecto social (relações de cooperação). 
La Taille (2006) realizou uma pesquisa com 5160 adolescentes do ensino médio, e entre outras questões, questionou-lhes sobre o grau de confiança que atribuíam à família. O resultado foi surpreendente: " $80,7 \%$ dos sujeitos afirmaram confiar muito na família, $16,6 \%$ afirmaram confiar, e a soma desses resultados $97,3 \%$ representou quase a totalidade da amostra”. (La Taille, 2006, p.176).

A mesma pesquisa ainda questionou aos jovens, o quanto os pais são vistos por eles como importantes na formação de seus valores. Mais uma vez, o resultado é impressionante, pois $67,6 \%$ afirmam que a família tem muita influência, e $25,1 \%$ afirmam que os pais têm média influência. Logo, o resultado somado, aponta para 92,7\% da amostra. Segundo o autor da pesquisa, os pais ocupam um lugar de destaque para os valores dos jovens pesquisados, e superam largamente as porcentagens das influências dos demais agentes sociais questionados: escola, mídia, instituições religiosas. (La Taille, 2006, p.177).

Desse modo, a influência da relação pais e filhos para a construção da autonomia moral dos jovens, comprovada pelo próprio reconhecimento dos filhos, é o objeto dessa investigação. Segundo, a teoria do Juízo Moral de Jean Piaget, somente nas relações de cooperação, o sujeito pode construir a autonomia moral, que lhe oportunizará a elaboração da personalidade e a inserção no mundo adulto. Os quatro fatores que, segundo tal teoria, possibilitam essa construção são: respeito, obediência, autonomia e justiça.

A partir da compreensão dos aspectos constituintes de cada fator, foram constituídos os itens da escala de concepções educativas, ou seja, o instrumento de investigação a que se propõe essa pesquisa. Os itens são apresentados a seguir no início de cada construto e depois discutidos no interior do texto. 


\subsection{OBEDIÊNCIA}

\begin{tabular}{|l|}
\hline \multicolumn{1}{|c|}{ OBEDIÉNCIA } \\
\hline 4- É fundamental que a ordem dada pelos pais, seja acompanhada de uma explicação. \\
\hline 8- Os filhos desobedientes devem saber que deixam os seus pais tristes. \\
\hline 15- Os pais devem sempre se esforçar para entender as razões da desobediência dos seus filhos. \\
\hline 18- Os pais sempre sabem o que é melhor para o seu filho. \\
\hline 23- Uma boa ameaça costuma resolver uma desobediência. \\
\hline 28- Os filhos devem obedecer os pais em todas as situações. \\
\hline 30- Os filhos que amam seus pais sempre devem lhes obedecer. \\
\hline 31- O papel dos pais é ser modelo para sustentar as regras junto aos filhos. \\
\hline
\end{tabular}

O psicólogo Milgran (1963) realizou uma pesquisa que se intitulou: "Estudo comportamental da obediência". Embora o método utilizado para o estudo se submetido atualmente aos atuais Comitês de Ética jamais fosse aprovado, por se tratar de uma "combinação ou farsa", na qual cidadãos comuns foram orientados a ministrar choques em um aluno-ator durante sessões de aprendizagem, esse trabalho oferece à pesquisa em psicologia moral um dado interessante: "Entre as várias definições possíveis de homem, os experimentos de Milgram nos levam a escolher a de 'animal obediente"”. (La Taille, 2002, p.37):

Durante a experiência, conforme os alunos (que eram atores) equivocavam-se nas respostas dadas às situações de aprendizagem, o participante deveria aplicar-lhe choques, que representavam punições para os erros dos alunos. Porém tais choques - conforme o grau de intensidade com que fossem aplicados - poderiam provocar a morte dos alunos. $\mathrm{O}$ experimento mostrou que alguns participantes, mesmo sabendo da questão da possibilidade do extremo prejuízo ao aluno, conforme o choque, o ministravam quando na presença do professor (que também era ator) que era a autoridade que lhes indicara tal procedimento. Portanto, os participantes obedeciam.

Os filhos devem obedecer aos pais? Os pais querem que os seus filhos sejam obedientes? O que significa obedecer? Pode-se chegar à possibilidade de ministrar choques violentos porque o professor (autoridade) mandou? Deve-se obedecer aos pais mesmo quando suas regras são inadequadas? O jovem autônomo é obediente? Os pais devem dar explicações 
a respeito de suas ordens? Os filhos que amam seus pais devem obedecê-los em quaisquer circunstâncias?

Para Piaget (1932), as crianças nascem na anomia, ou seja, na ausência total de regras. Até os três anos a criança já ouviu algumas correções de seus pais, quando já não foi punida, infelizmente, às vezes, até fisicamente, porém, a sua inteligência sensório- motora ainda representa um empecilho para a construção da primeira forma de moral: a heteronomia.

Para o autor, a heteronomia, ou a primeira fase do desenvolvimento moral infantil é chamada de moral da obediência, pois diz respeito às primeiras formas da consciência do dever na criança e que se fundamentam nas atitudes das crianças que obedecem ou deveriam obedecer as regras impostas pelos mais velhos - seus pais, irmãos, professores e outros adultos com os quais convive - ao reconhecer neles, a fonte e o modelo dessas regras.

É bom todo ato que testemunhe uma obediência à regra ou mesmo uma obediência aos adultos, quaisquer que seja as instruções que prescrevam; é mau todo ato não conforme as regras. Portanto, a regra não é absolutamente uma realidade elaborada pela consciência, nem mesmo julgada ou interpretada pela consciência: é dada tal e qual, já é pronta, exteriormente à consciência; além disso, é concebida como revelada pelo adulto e imposta por ele. Então, o bem se define rigorosamente pela obediência. (Piaget, 1932/1994, p. 93).

Para Piaget, o menino heterônomo obedece a partir de um controle interno já existente, instalado pelo reconhecimento da autoridade na pessoa dos seus pais e desta forma pode-se caracterizá-lo moral. O menino edípico ${ }^{15}$ ainda é pré-moral, isto é, obedece em virtude da presença de uma relação de poder, de forças que lhe são maiores e que o conduzem à obediência para evitar a punição ou a perda do afeto.

Piaget cita a teoria do psicólogo Baldwin (citado por Piaget, 1932/1994, p.288) para explicar o surgimento dos primeiros sentimentos morais nas relações interindividuais, ou seja, para explicar a gênese da obediência. Segundo suas próprias palavras, referindo-se a tal teoria:

A obediência, de fato, não é, nem uma imitação simples, nem uma ejeção: a obediência cria um novo 'eu', uma fração do 'eu' que domina as outras. Com efeito, aprendendo a obedecer, a criança constrói-se, por si mesmo, o que Baldwin chama um 'eu ideal', um 'eu' submisso às decisões dos adultos, isto é, um 'eu' calcado sobre o 'eu' superior deles. (1932/2000, p.289)

\footnotetext{
${ }^{15}$ Essa pesquisa não se fundamentará na abordagem psicanalítica, por isso, não se aprofunda nas explicações a respeito do Complexo de Édipo (1923/2006), proposto por Freud, todavia, referências a essa abordagem e suas explicações sobre a adolescência e sobre a relação pais e adolescentes, podem ser encontradas nos capítulos 2 e 3 respectivamente.
} 
Baldwin (citado por Piaget,1954/1994, p.259) se refere à construção do "eu ideal” que, segundo ele, origina-se da imitação dos gestos do outro, o que providencia a tomada de consciência de si a partir da tomada de consciência das semelhanças com os outros. Piaget observa a pertinência de tais concepções do autor e considera o conceito de "eu ideal" análogo ao conceito de "superego" freudiano, nas características que dizem respeito à explicação da obediência (1954/1994, p.259).

Porém, para o Piaget a construção do "ego ideal" não é suficiente para explicar o sentimento de obrigação que leva o sujeito a agir moralmente, isto é, a obediência é para Baldwin, inicialmente, uma conduta de submissão aceita que tenderá a um julgamento racional por parte do indivíduo, em estágios superiores. Porém isto ainda não basta para Piaget, embora concorde e reconheça a importância de tal teoria naquilo que diz respeito a "admitir que o eu somente se conhece por referência àquele dos outros" (1932/2000, p.292).

Piaget encontrará em Pierre Bovet (citado por Piaget, 1954/1994, p. 260) a explicação que adotará para justificar os sentimentos de obrigação que conduzem o sujeito a agir moralmente, ou, especialmente na fase da construção dos primeiros sentimentos morais, conduzem-no a obedecer aos seus pais.

A regra da coação, ligada ao respeito unilateral, é considerada como sagrada e produz no espírito da criança sentimentos análogos àqueles que caracterizam o conformismo obrigatório das sociedades inferiores. Mas permanece exterior à consciência da criança e não conduz como desejaria o adulto a uma obediência efetiva. A regra devido a acordo mútuo e à cooperação enraíza-se, pelo contrário, no interior mesmo da consciência da criança e conduz a uma prática efetiva, na medida em que se associa com a vontade autônoma." (Piaget, 1932/1994, p. 270).

Logo, para Piaget o desenvolvimento moral é composto de duas morais respectivamente: heteronomia e autonomia. $\mathrm{O}$ autor reconhece muitíssimo o papel dos pais na gênese da moralidade infantil, depois afirmará que, infelizmente, os pais se transformam em psicólogos medíocres e quando deveriam possibilitar as relações de cooperação que favoreceriam a superação da moral da obediência, os pais têm o hábito de continuar impondo suas vontades fazendo esmorecer e dobrar a vontade da criança. (Piaget, 1932/1994, p.152)

Parece que em muitos pontos de vista o autor está certo, pois muitos pais ainda acreditam que a melhor forma de se fazerem obedecer pelos seus filhos é a imposição da sua autoridade, através dos gritos, das ameaças, dos castigos físicos, pois admitem que, dessa forma, as crianças entendem quem manda, sentem medo e cumprem os seus deveres (Caetano, 2005, p. 135). Essa forma de relação interindividual fundamentada na coação, segundo Menin (1996, p. 51), tem um formato de educação na qual o adulto impõe ao jovem 
o que deve ser feito, mediante conseqüências positivas e negativas para a desobediência ou para a obediência, sendo a tendência de que o filho obedeça por medo ou por afeto e que se molde desse modo aos pais, imitando-os:

Assim é que as crianças pequenas não só aprendem a fazer o que devem, mas a se tornar iguais a quem lhes manda. Tornando-se caricaturas de pais, de professores, de chefes... reproduzindo por aí suas ordens, seus valores, seus julgamentos... (Menin, 1996, p. 51).

Dessa forma, quando os pais ao longo do desenvolvimento das crianças, em nome de sua educação, agem de forma a impor os seus valores, desejos e regras aos seus filhos, promovem interações que não conduzem a autonomia. Seguem alguns exemplos típicos desse tipo de atitudes:

- Quando os pais não explicam aos seus filhos a razão de ser das regras, impedindo-os de refletirem sobre os princípios que fundamentam os deveres, a fim de legitimá-los como acordos mútuos que fundamentam o bem comum;

- quando diante de uma atitude inadequada do filho, os pais ministram castigos cujos conteúdos não têm qualquer relação como ato sancionado. Por exemplo, quando o adolescente fica sem internet por não ter cumprido a sua parte das tarefas domésticas da casa;

- quando os pais agem de modo indiferente, deixando de falar com o filho, negando-lhe atenção, afirmando que só voltarão a lhe falar quando passar a tristeza e a decepção que sentem por ele, oriundas de suas atitudes de desobediência e negligência para com as ordens impostas;

- quando se utilizam de ameaças, humilhações e outras técnicas, cujo maior objetivo é fazer o desejo do adulto, muitas vezes arbitrário; há ainda os pais que supervalorizam as situações que envolvem danos materiais, e não trabalham com seus filhos as questões dos valores;

- quando negligenciam o seu papel, deixando "as rédeas correrem soltas" e depois procurando resolver as encrencas nas quais os filhos se envolvem para protegê-los.

Para Piaget, todas as atitudes descritas acima, são exemplos de relações de coação, que, não são favoráveis ao desenvolvimento moral. De acordo com suas próprias palavras:

Reconhecemos, com efeito, a existência de duas morais na criança, a da coação e a da cooperação. A moral da coação é a moral do dever puro e da heteronomia: a criança aceita do adulto um certo número de ordens às quais deve submeter-se, quais 
quer que sejam que sejam as circunstâncias. O bem é o que está de acordo, o mal o que não está de acordo com essas ordens: a intenção só desempenha pequeno papel nessa concepção, e a responsabilidade é objetiva. (Piaget, 1932/1994, p.250)

O modo como os pais educam seus filhos, ou seja, o conjunto de atitudes que utilizam para que os seus filhos cumpram os seus deveres e cresçam como pessoas de bem, é foco de pesquisas que classificam essas atitudes e definem modelos de práticas e estilos parentais ${ }^{16}$. Conforme tais estudos, as práticas parentais apresentam correlação com fatores da saúde mental dos adolescentes como: tendência à depressão, comportamentos anti-sociais, comportamentos de risco, além de questões relativas ao desempenho escolar, e outros.

Para a teoria piagetiana, quando não se estabelecem relações de cooperação, ou seja, quando as crianças e os jovens não têm a oportunidade da vivência de relações de respeito mútuo, que lhes garanta a reciprocidade, a tomada de consciência e a troca de pontos de vista, a tendência é que se mantenham heterônomos. As pesquisas de Kohlberg (1981, 1984, 1987), por exemplo, revelaram que a grande maioria das pessoas permanece nos níveis mais baixos de desenvolvimento moral do seu modelo, sendo mínimo o número de pessoas que podem ser consideradas autônomas. Segundo, Kamii e Declark (1988) o fato de muitos jovens e adultos permanecerem heterônomos, pode ser assim explicado: "Os adultos exercem seus poderes sobre as crianças usando de recompensas e punições e são essas ações que as mantêm obedientes e heterônomas". (Kamii e Declark, 1988, p.71).

Comumente os pais de adolescentes costumam reclamar do seu comportamento desobediente. Normalmente, a criança quieta, comportada e obediente, transforma-se em um jovem rebelde. A questão do conflito entre pais e filhos na adolescência é tema de algumas pesquisas que se propõem a investigar a adolescência, porém segundo autores como Maccoby e Martin (1983), Smetana (1989), Steinberg (2001), os conflitos na adolescência fazem parte da convivência e salvo as exceções são resolvidos sem maiores problemas.

Entretanto, quando os pais não têm sensibilidade e conhecimento suficientes para através dos conflitos inerentes à relação com os filhos adolescentes, auxiliá-los na construção da autonomia, e, portanto, insistem na imposição de suas ordens e regras, alguns problemas na formação da personalidade podem ser evidenciados. Segundo Piaget (1932/1994) o grande problema das relações de coação, é que tendem a formar três tipos de personalidade: o mais comum é o cálculo de riscos; a segunda possibilidade é a conformidade cega e o terceiro resultado possível é a revolta. (Kamii e Declark, 1988, p.71).

\footnotetext{
${ }^{16}$ Tais pesquisas pertencem a abordagem comportamental cujos instrumentos de pesquisa e resultados são apresentados no capítulo cinco.
} 
Assim, muitas vezes o que acontece na adolescência, é que, a partir da construção do raciocínio formal que amplia as possibilidades do raciocínio do adolescente, o jovem passa a questionar as regras impostas pela coação, observa também as incoerências de seus pais, verbaliza as suas opiniões e acaba dessa forma rotulado de rebelde. A partir das vivências das relações com seus pares (Youniss \& Smollar, 1985), o adolescente experimenta as relações de cooperação, e busca dessa forma construir a sua liberdade, que não significará romper com os seus pais, mais buscar relações nas quais estejam presentes o respeito mútuo e os acordos mútuos. Segundo Piaget:

Não é livre o indivíduo que está submetido à coerção da tradição ou opinião dominante, que se submete de antemão a qualquer decreto da autoridade social e permanece incapaz de pensar por si mesmo. Tampouco é livre o indivíduo cuja anarquia interior impede-o de pensar e que, dominado por sua imaginação ou por sua fantasia subjetiva, por seus instintos e por sua afetividade, é jogado de um lado para o outro entre todas as tendências contraditórias de seu eu e de seu inconsciente. É livre, em contrapartida, o indivíduo que sabe julgar, e cujo espírito crítico, o sentido da experiência e a necessidade de coerência lógica colocam-se a serviço de uma razão autônoma, comum a todos os indivíduos e independente de toda autoridade exterior." (Piaget, 1945/1998, p.154)

Portanto, para Piaget $(1930,1945,1948)$ a educação deve favorecer a construção da autonomia que evoca o respeito e a liberdade dos direitos de si mesmo e dos outros, e ela não pode se desenvolver numa atmosfera de autoridade e opressão moral e intelectual. Os pais devem sempre se esforçar para expor aos filhos a razão de ser das regras, para lhes oferecer a possibilidade de boas escolhas, bem como educá-los para a tomada de consciência de suas ações a partir do arcar com a consequiência dos seus atos. O autônomo é, portanto, obediente sim, mas obediente a princípios de justiça comumente acordados. 


\subsection{RESPEITO}

\begin{tabular}{|l|}
\hline \multicolumn{1}{|c|}{ RESPEITO } \\
\hline 1- Um pai sempre mostra interesse pelas coisas que o filho faz. \\
\hline 2- Um pai nunca deve mexer nas coisas do filho sem pedir permissão. \\
\hline 6- É fundamental que os pais conversem com seus filhos. \\
\hline 10 - Os pais devem usar ofensas quando necessário para educar seus filhos. \\
\hline 12- Um pai nunca deve confiar no filho. \\
\hline 14- Um pai não deve sempre justificar para os filhos as suas orientações. \\
\hline 17- Os pais devem dar palpite em tudo o que o filho faz. \\
\hline 20- Um pai nem sempre deve trocar idéias com seus filhos. \\
\hline 22- Um filho sempre deve acatar as ordens dos pais. \\
\hline 26- As atitudes dos pais para com os filhos são sempre coerentes. \\
\hline
\end{tabular}

Um pai deve mexer nas coisas do filho sem sua permissão? Essa questão levanta muitas discussões, porém dois argumentos são escolhidos e comentados aqui devido a sua contradição: o primeiro, postula para o fato de que o pai deve e pode mexer nas coisas do filho para acompanhar o seu desenvolvimento, para checar se está tudo bem com ele, isto é, se não há indícios de envolvimento com más companhias, com situações de risco, portanto, trata-se de uma atitude justificável pela virtude do cuidado com o filho, função de todo e qualquer pai. $\mathrm{O}$ segundo argumento afirma que os pais se constituem em fonte de regras e de deveres para os filhos e que, deste modo, precisam ser pessoas que cumpram as regras apresentadas, para que o sujeito possa contar com aquilo que garante o desenvolvimento da consciência de obrigação: boas regras e boas pessoas.

Piaget (1932/1994, p. 277) busca na teoria de Bovet a explicação para a gênese do sentimento de obrigatoriedade moral, ou seja, o que faz com que a criança se empenhe em obedecer às regras, ou acordos propostos pelo ambiente no qual convive com os adultos, principalmente seus pais. O autor concorda com a proposta de Bovet de que há a necessidade de contato entre dois indivíduos pelo menos para constituir uma regra obrigatória. Segundo as suas palavras:

Duas condições são necessárias e sua reunião suficiente para que tenha origem o fato da obrigação: de um lado, que o indivíduo receba ordens e, de outro lado, que aquele que as recebe respeite aquele que às dá; sem ordens, nem regras, portanto, nem 
deveres, mas, sem respeito, as ordens não seriam aceitas, portanto, as regras não poderiam obrigar a consciência. (Piaget, 1932/1994, p. 278)

Dessa forma, é dever dos pais não mexer nas coisas do filho sem a sua permissão. Esse simples exemplo de situação tão corriqueira da convivência entre pais e filhos, ilustra o que Piaget explica como a diferenciação entre respeito mútuo e respeito unilateral. Já no período da gênese da moralidade, quando a criança pequena começa a ser introduzida no mundo regrado dos adultos, os dois tipos de respeito propostos por Piaget, se diferenciam e, a evolução desse sentimento pode ser observada na teoria piagetiana:

Acontece, de fato, que a criança em presença de seus pais, tem espontaneamente a impressão de ser ultrapassada por algo superior a ela. Logo, o respeito mergulha suas raízes em certos sentimentos inatos e resulta de uma mistura sui generis de medo e afeição, que se desenvolve em função das relações da criança com seu ambiente adulto. (Piaget, 1932/1994, p. 279)

Esse primeiro tipo de sentimento - o respeito unilateral - é um sentimento experimentado pelos pequenos em relação aos maiores e explica a gênese da moralidade, na medida em que a criança em contato com o outro, experimenta a convivência com as regras e as percebe como sagradas e como imutáveis porque oriundas de alguém por quem a criança sente simpatia, além de medo ou temor, que inicialmente é temor do castigo pela desobediência, receio de perder o afeto e os cuidados desse adulto, ou seja, o respeito unilateral, próprio das relações de moral heterônoma.

Segundo Macedo (1996, p. 195) o respeito unilateral supõe duas formas de relação de heteronomia e sentimento de dever. A primeira faz sentido ao menos do ponto funcional, pois é querida por aqueles que se submetem ao outro. Como exemplo, o autor cita a submissão de alguns a um conjunto de regras dadas arbitrariamente para participarem de um jogo. Não têm autonomia para mudar ou alterar as regras do jogo, e, se quiserem jogá-lo devem submeter-se.

Por outro lado, outra forma de respeito unilateral é aquele que supõe a desigualdade entre o que respeita e o respeitado, e a coação é o procedimento da educação da criança pelo adulto, como o exemplo acima relatado daquele pai que acredita que em nome da educação, e do cuidado pelo filho, pode invadir o limite da propriedade alheia, mexendo nas suas coisas sem lhe pedir permissão, ou dando palpite em tudo o que o filho faz, invadindo dessa vez a sua liberdade de fazer escolhas independentemente da opinião paterna ou materna.

O segundo tipo de respeito, o respeito mútuo, pelo contrário, é próprio das relações de cooperação, que conduzem à autonomia. Segundo a conceituação de Piaget: 
$\mathrm{O}$ respeito unilateral ou respeito do menor pelo maior desempenha um papel essencial: leva a criança a aceitar todas as instruções transmitidas pelos pais e é assim o grande fator de continuidade das gerações. [...] O respeito mútuo aparece como a condição necessária da autonomia, sob seu duplo aspecto intelectual e moral. Do ponto de vista intelectual, liberta a criança das opiniões impostas, em proveito da coerência interna e do controle recíproco. Do ponto de vista moral, substitui as normas da autoridade pela norma imanente à própria ação e à própria consciência, que é a reciprocidade na simpatia. (Piaget, 1932/1994, p. 91)

A questão é que o adulto não é capaz de utilizar-se somente do respeito mútuo. $\mathrm{O}$ respeito mútuo é próprio da relação entre iguais, portanto implica na reciprocidade, e a relação entre pais e filhos não é recíproca pois se constitui em uma relação de desigualdade pela presença da autoridade. Porém Piaget afirma que não se pode atingir a autonomia a partir de relações apenas fundamentadas nas relações de coação e no respeito unilateral. Conforme suas palavras:

... a educação moral fundada sobre o respeito exclusivo ao adulto ou às regras adultas desconhece este dado essencial da psicologia de que existe na criança não uma, mas duas morais presentes; assim os procedimentos educativos fundados somente no respeito unilateral negligenciam a metade, e não a menos importante, dos profundos recursos da alma infantil. (Piaget, 1930/1996, p.12)

Os problemas na relação pais e filhos são visíveis e observáveis nos dados empíricos de pesquisas de desenvolvimento moral. Os pais não têm certeza de seus valores ao educar, e, portanto, acabam confundindo em primeiro lugar o seu próprio papel na formação do filho, não tendo clareza de seus objetivos ao educar. (Caetano, 2005). Segundo, Macedo (1996, p.197), "professores e pais tornaram-se ambivalentes e críticos de sua função docente ou paterno/materna. Perderam o respeito pelo seu lugar. Encheram-se de dúvidas". Pensando nessas considerações, duas dificuldades se apresentam:

A primeira é que: ainda que não seja suficiente para a construção da moralidade, o respeito unilateral tem a sua importância para tal construção, enquanto gênese da moralidade na criança. Logo, se os pais abdicam de seu papel enquanto fonte e modelo de regras, as crianças permanecem na anomia.

... o respeito unilateral é de grande importância prática, porque é assim que se constitui a consciência elementar do dever e o primeiro controle normativo do qual a criança é capaz. Mas parece-nos evidente que esta aquisição não basta para constituir a verdadeira moralidade. (Piaget, 1932/2000, p.299)

Por outro lado, se os pais insistem na heteronomia, impondo às crianças regras 
inquestionáveis, acreditando que os filhos devam acatar as ordens dos pais, e não se disponibilizando a explicar as justificativas para tais regras, negando-se também a dialogarem com seus filhos, e inclusive fazendo-se valer de ofensas, sob o pretexto de educá-los, estarão reforçando através do respeito unilateral, a permanência do sujeito na heteronomia através de relações interindividuais fundamentadas na coação:

A grande diferença entre a coação e a cooperação, ou entre o respeito unilateral e o respeito mútuo, é que a primeira impõe crenças ou regras completamente feitas, para serem adotadas em bloco, e a segunda apenas propõe um método de controle recíproco e de verificação no campo intelectual, de discussão e de justificação no domínio moral. (Piaget, 1932/1994, p. 83)

Daí, o autor afirmar que, dificilmente os pais conseguem atuar junto aos filhos sem utilizarem-se da coação. Mesmo os pais conhecedores dos aspectos referentes ao desenvolvimento moral do sujeito - casos raros, visto que a maioria dos pais desconhece as características do desenvolvimento de seus filhos - têm grande dificuldade para fundamentar a educação dos jovens no respeito mútuo, e, conforme se apontou no primeiro capítulo desse trabalho, alguns pais chegam a abdicar do seu papel de genitores, deixando o jovem sozinho nesse processo de tornar-se adulto, fator, igualmente, pernicioso.

Piaget, afirma que:

Entre o respeito unilateral do pequeno, que recebe uma ordem sem réplica possível, e o respeito mútuo de dois adolescentes, que trocam seus pontos de vista, há todos os intermediários. Nunca há coação pura, portanto, nunca há respeito puramente unilateral: a criança, por mais submissa que seja, tem a impressão de que pode ou poderia discutir, que uma simpatia mútua envolve as relações, por mais autoritárias que sejam. Inversamente, nunca há cooperação absolutamente pura: em toda discussão entre iguais, um dos interlocutores pode fazer pressão sobre o outro através de desafios, ocultos ou explícitos, ao hábito e à autoridade. (Piaget, 1932/1994, p.79).

Portanto, educação moral é um processo que necessita de compromisso e confiança por parte do adulto, de modo a providenciar para a relação com os adolescentes, a confiança recíproca. Auxiliar a criança a conhecer e respeitar as regras, refletindo sobre elas, compreendendo os seus princípios de modo que ela possa expor seus pontos de vista e tenha a oportunidade de realizar escolhas, arcar com as consequiências de seus atos e trocar pontos de vista, para que, quando for adulta, possa ter legitimado as regras e tê-las compreendido como representadoras do bem comum, implica em um processo complexo no qual os tipos de relações interindividuais vivenciadas por esse jovem, farão toda a diferença: "Regra supõe 
respeito e este implica autoridade, disciplina, referência, entrega e sobretudo trabalho e construção". (Macedo, 1996, p.194).

Sobre a questão da autoridade, disciplina e referência, La Taille (1996, p. 174) afirma que:

a questão do lugar da disciplina ainda inquieta pais e educadores. Hoje, ouve-se muito falar que as crianças precisam de 'limites', e que, justamente, não os têm (tema essencialmente de classe média, deve-se convir). Da preocupação com impor limites a voltar a uma educação moral 'disciplinar', no sentido tirânico da palavra, é só um passo.

A questão é que, os pais podem acabar sendo autoritários demais, de modo que não permitam aos seus filhos a experiência da troca de pontos de vista e da construção da autonomia. Por outro lado, em nome de uma educação anti-autoritarismo, o inverso também é freqüente, ou seja, os pais deixam de cumprir o seu papel de autoridade, e a excessiva permissividade ou a negligência, tornam-se da mesma forma prejudiciais à formação do jovem. Muitos sequer demonstram interesse pelas coisas que o filho faz, sendo raros os momentos de conversa com as crianças e especialmente, com os adolescentes.

Piaget, afirma que:

Primeiro, é preciso distinguir, o mútuo consentimento em geral e o respeito mútuo. Pode haver mútuo consentimento no vício, porque nada impede que as tendências anárquicas de um indivíduo convirjam para as do outro. Ao contrário, quem diz "respeito" (isso é verdadeiro, pelo menos no tocante ao respeito mútuo) diz admiração por uma personalidade, enquanto, justamente, essa personalidade se submete as regras. Portanto, só poderá haver respeito mútuo por aquilo que os próprios indivíduos considerarem como moralidade.” (Piaget, 1932/1994, p. 84)

A partir dessa citação de Piaget, pode-se falar do trabalho de referência e entrega que compete aos pais que desejam proporcionar aos seus filhos uma educação de respeito mútuo. Os procedimentos para uma educação pautada nesse tipo de relação interindividual requerem que os pais sejam coerentes para com as suas atitudes junto aos seus filhos, que incentivem o seu filho a falar de si mesmo, de seus pensamentos e sentimentos, para que a reciprocidade se faça presente na relação, e, para que, sendo ouvido, compreendido e orientado, o filho possa construir a autonomia. Segundo Piaget: "O respeito mútuo é ima espécie de forma limite de equilíbrio para a qual tende o respeito unilateral, e pais e professores devem fazer de tudo o que for possível, segundo cremos, para converterem-se em colaboradores iguais à criança”. (1930/1996, p.14).

Portanto, para o autor a moralidade implica nas relações interindividuais: 
Ora, sem relação com outrem, não há necessidade de moral: o indivíduo como tal conhece apenas a anomia e não a autonomia. Inversamente, toda a relação com outrem, na qual intervém o respeito unilateral, conduz à heteronomia. A autonomia só aparece com a reciprocidade, quando o respeito mútuo é bastante forte, para que o indivíduo experimente interiormente a necessidade de tratar os outros como gostaria de ser tratado. (Piaget, 1932/1994, p. 155).

Esse é outro ponto difícil na relação pais e filhos. O respeito unilateral se explicita na relação pais e filhos, de forma nítida quando se reflete sobre essa frase piagetiana: "a necessidade interior que o sujeito possui de tratar os outros da mesma forma que gostaria de ser tratado". Talvez esse seja o melhor conceito para a idéia de respeito e, por isso, tão ausente das relações pais e filhos. Que pai costuma pensar antes de repreender o seu filho: como eu me sentiria se fosse eu o filho e meu pai falasse comigo assim? Daí todos os conflitos que permeiam a relação entre pais e filhos na adolescência, pois os jovens segundo o desenvolvimento psicológico se julgam iguais aos seus pais, mas esses últimos, por outro lado, ainda assumem essa postura de poder e superioridade.

Logo, é muito comum um pai ofender ou humilhar um jovem em nome de um processo educativo, e se sentir exasperado e injustiçado quando o seu filho lhe responde em um mesmo patamar. Frases do tipo: "Eu sou sua mãe e não admito que você fale comigo dessa maneira", são comuns e legitimadas. Pena que a recíproca não possa ser verdadeira: "Eu sou seu filho, não fale comigo dessa maneira".

Conforme já se argumentou anteriormente, segundo Bovet (Piaget, 1932/1994, p. 84) o aparecimento da consciência do dever é fruto do respeito às regras e àqueles que as prescrevem, ou seja, os adultos. Portanto a idéia de que os sentimentos morais estão ligados ao respeito que os indivíduos têm uns pelos outros é incontestável. Assim Piaget concordará com o pressuposto do conceito de respeito para o autor citado, que afirma que, "o respeito se encaminha às pessoas e provêm das relações dos indivíduos entre si”, porém, apontará a necessidade de observação desse tipo de respeito, intitulado por ele de respeito mútuo, cuja definição amplifica o respeito apontado por Bovet e questiona o conceito de respeito em Kant, que é inexplicável do ponto de vista da experiência, pois o que se respeita não é a pessoa, nem o grupo, mas a lei moral, ou seja, ignora a necessidade das relações interindividuais. (Piaget, 1954/1994, p.260). O conceito de Durkheim, para quem o respeito se dirige ao grupo e resulta da pressão do grupo sobre o indivíduo é, portanto, sempre respeito unilateral. (Piaget, 1930/1996, p. 11). 
Para o autor, o respeito é sim o sentimento que desencadeia o sentimento de obrigação dos sujeitos para com as regras, e é fruto das relações com o outro, exatamente por isso, se o respeito permanecer unilateral pode-se correr o risco de que o indivíduo que obedece experimente o sentimento do bem, na medida em que respeita outrem e se submete a ele por respeito, ou seja, o bem está em obedecer o outro. (Piaget, 1932/1994, p. 84). Por outro lado, o respeito mútuo, que é a forma evoluída do respeito, fruto das relações de cooperação, se estabelece na reciprocidade, que para o autor regula a avaliação tanto do bem quanto do mal, através da mútua coordenação dos pontos de vista e da ação. Nas suas palavras: “...o respeito mútuo ainda é composto de afeição e medo, mas só conserva deste último o temor de decair aos olhos do parceiro". (Piaget, 1948/2000, p. 67). Pode-se ainda complementar que, o temor do respeito mútuo não é o do desamor, ou do castigo, mas o medo de decair aos olhos de si mesmo. Somente este tipo de relação, pautada no respeito mútuo é formadora de valores morais. 


\subsection{JUSTIÇA}

\begin{tabular}{|l|}
\hline \multicolumn{1}{|c|}{ JUSTIÇA } \\
\hline 5- Quando o filho faz alguma coisa errada, o pai deve proibi-lo de fazer algo que ele goste. \\
\hline 9- Os pais devem sempre contornar os erros dos filhos para não viverem brigando com eles. \\
\hline 11- Um pai deve sempre se auto-controlar para castigar seu filho. \\
\hline 16- Um pai pode punir fisicamente seu filho caso ele faça algo muito errado. \\
\hline 19- Um pai que tem dois filhos precisa sempre agir do mesmo modo com os dois. \\
\hline 24- Um pai deve ajudar seu filho a arcar com as conseqüências dos seus atos. \\
\hline 35- O pai pode falar e não agir conforme as suas palavras. \\
\hline 36- Os filhos devem respeitar os pais mesmo que os pais não os respeitem. \\
\hline
\end{tabular}

O sentimento de justiça tem um significado todo especial para a teoria do juízo moral em Piaget (1932/1994). Segundo ele, a justiça é a condição imanente e a lei de equilíbrio das relações, e, dessa forma, as noções de justo e injusto são elaboradas pela criança e se desenvolvem normalmente à revelia da interferência do adulto, como fruto das relações de cooperação:

...se o aspecto afetivo da cooperação e da reciprocidade escapa do interrogatório, há uma noção, a mais racional, sem dúvida, das noções morais, que parece resultar diretamente da cooperação, cuja análise psicológica pode ser tentada sem muitas dificuldades: a noção da justiça. (Piaget, 1932/1994, p.156).

Dessa forma, para o pai que quer cooperar com o seu filho uma boa questão é sempre essa: estou sendo justo? Quando a resposta é que, sim, porque o adolescente desobedeceu e merece por isso ficar sem aquilo que mais gosta, podemos dizer que a noção de justiça presente é a retributiva, ou seja, a menos evoluída, que se define pela proporcionalidade entre o ato e a sansão.

Há duas noções distintas de justiça. Dizemos que uma sanção é injusta quando pune o inocente, recompensa um culpado ou, em geral, não é dosada na proporção exata do mérito ou da falta. Dizemos, por outro lado, que uma repartição é injusta quando favorece uns à custa de outros. Nesta segunda acepção, a idéia de justiça implica apenas a idéia de igualdade. Na primeira acepção, a noção de justiça é inseparável daquela de sanção e define-se pela correlação entre os atos e sua retribuição. (Piaget, 1932/1994, p. 157) 
Muitas vezes a justiça retributiva é a mais utilizada pelos adultos. Segue um relato interessante: "Em um consultório médico uma mãe grita ao telefone com sua filha que, pelo teor da conversa, tinha mais ou menos dezoito anos: 'quer dizer que o seu namorado ligou para você, dizendo que o carro dele tinha quebrado e você saiu de madrugada para ajudálo?' - pausa para que a filha falasse - a mãe continua em um tom mais irritado: 'como assim, qualquer um faria isso, você está querendo me afrontar menina' - outra pausa - a mãe continua: 'eu falo com você como eu quiser, sou eu quem lhe dou tudo, o carro, seu apartamento e você é que não tem o direito de falar comigo assim' - a mãe desliga o telefone, que volta a chamar em seguida, mas a mãe manda a secretária dizer à filha que ela não falaria mais com ela."

Qual é a justiça empregada nesse exemplo? A justiça retributiva do tipo toma-lá-dá-cá: "Eu lhe dou carro e apartamento e você me obedece. Você me desafia, eu tiro tudo de você, inclusive, e, especialmente, o respeito em ouvir o seu ponto de vista". Piaget (1932/1994) encontrou essa forma de justiça entre as crianças mais novas, todavia alega que:

Para uns, a sanção é justa e necessária; e tanto mais justa quanto mais severa; é eficaz no sentido de que a criança devidamente castigada saberá, melhor que a outra, cumprir seu dever. [...] essa noção, subsiste em qualquer idade, mesmo entre muitos adultos, favorecido por certos tipos de reações familiares ou sociais. (Piaget, 1932/1994, p. 159)

Para o autor, dois elementos constituem a justiça retributiva: as noções de expiação e recompensa, e por outro lado, a reposição ou reparação, que constitui o elo de solidariedade com o grupo, quebrado pelo "culpado" ao descumprir a regra. Da mesma forma pode-se afirmar a existência de três origens para os aspectos principais da retribuição: "certas reações individuais condicionam o aparecimento da retribuição, a coação adulta explica a formação da noção da expiação, e a cooperação explica os destinos ulteriores da noção de sanção.” (Piaget, 1932/1994, p.241)

Sobre punição Piaget (1932/1994, p.241) afirma que a intervenção do adulto desempenha uma função de, somada aos fatores individuais, desencadear psicologicamente na criança a idéia de sanção expiatória. Porque a criança gosta de seus pais e desde bebê tem seus comportamentos sancionados por eles, acaba por compreender a sanção como moralmente obrigatória, pois para ela, aceitar as punições constitui a mais natural das reparações. Conforme as palavras do autor:

Esta noção 'primitiva' e materialista da sanção expiatória, portanto, não é, segundo nós, imposta tal e qual pelo adulto à criança, e talvez nunca tenha sido inventada por 
uma consciência psicologicamente adulta. Mas é o produto fatal da punição, sendo esta refratada através da mentalidade misticamente realista da criança. (Piaget, 1932/1994, p.241)

É justo o pai bater no seu filho? Seja qual for a situação? Não, a resposta é não. A agressão física é o exemplo por excelência de sansão arbitrária. Não há nenhuma regra quebrada, que possa ser ressarcida por um ato de violência, ainda que uma criança tenha batido na outra em meio a um conflito, bater nela para que sinta o quanto doeu na outra, é na verdade ensiná-la que os mais fortes batem nos mais fracos, e, que sempre que se tem um problema, uma solução pode ser a agressão. As crianças necessitam vivenciar formas mais elaboradas e evoluídas de solucionar conflitos para poder construírem também tais possibilidades. (Selman, 1989, Sastre \& Moreno, 2002).

Se o símbolo é necessário para os que são inaptos para compreender as razões de repreensão, perde toda a necessidade para os que compreendem. Além disso, se a sanção não tem outra relação com o ato sancionado que não a de simples símbolo, será sempre "arbitrária" em seu conteúdo. Ora, é justamente o que a consciência racional não poderia admitir e o que procuram evitar os que querem fazer da sanção a consequiência natural do ato." (Piaget, 1932/1994, p. 273).

A proposta de Piaget (1932/1994, p.162) é que, quando uma regra é quebrada, e com isso o elo de solidariedade com o grupo é desfeito, devem se utilizar sansões por reciprocidade que fazem compreender ao culpado o significado de sua falta: há relação de conteúdo e de natureza entre falta e punição. Portanto, não há dúvida que, todo pai necessita buscar o auto-controle no momento de punir seu filho. Normalmente, quando os filhos fazem algo errado, ou desobedecem aos pais, ou, pior ainda, quando as faltas trazem prejuízos financeiros (infelizmente, os danos materiais, para alguns pais sempre desencadeiam mais a fúria do que as questões morais ou os valores propriamente ditos - Caetano, 2005, p. 161), tais conflitos costumam desencadear reações nervosas, e, os pais necessitam sempre se lembrarem de que são os adultos da relação.

Por outro lado, alguns pais, para não viverem em constante briga ou desentendimento com os seus filhos, buscam contornar os erros dos mesmos, impedindo-os de arcar com as conseqüências dos seus atos. Esse tipo de atitude é injusto também, para com aqueles que estão em formação, pois, as sansões são necessárias para que se possam vivenciar a reciprocidade nas relações, e para que, se possa tomar consciência da legitimidade da regra quebrada. "Constatamos que a sanção que parece mais justa no estágio da cooperação é aquela que deriva da idéia da reciprocidade”. (Piaget, 1932/1994, p. 273) 
Piaget (1932/1994, p.236) afirma que conforme os resultados de suas pesquisas, o desenvolvimento infantil é marcado por três grandes períodos no tocante a evolução da noção de justiça. O primeiro período se refere aquele em que a justiça está subordinada à autoridade, trata-se da justiça retributiva, já descrita nos parágrafos anteriores, um segundo período no qual a criança vivencia um igualitarismo progressivo, e o último período, marcado pelo acréscimo das preocupações de eqüidade à justiça puramente igualitária.

Acontece frequentemente que os pais ou os professores favorecem a criança obediente em detrimento das outras. Tal desigualdade de tratamento, justa do ponto de vista retributivo, é injusta do ponto de vista distributivo. (Piaget, 1932/1994, p. 200).

Um pai que tem dois filhos deve sempre agir do mesmo modo com os dois? Caso a pergunta fosse outra ainda: É justo um pai punir um filho desobediente deixando-o sem presente e presenteando os outros filhos obedientes? A primeira questão diz respeito à noção de justiça distributiva, que se define pela igualdade e a segunda diz respeito à noção da justiça retributiva, relacionada a sansão.

Quanto à segunda pergunta precisa ser subdividida: pensando que os dois são filhos e que têm direitos comuns, a resposta seria sim, um pai deve agir do mesmo modo com os dois filhos, mas se os filhos fossem os da segunda pergunta, ou se tratasse de um filho bebê e outro adolescente, é impossível que os pais ajam da mesma maneira com ambos. No primeiro caso, o pensamento diz respeito à justiça distributiva por igualdade:

Mas, para que haja real igualdade e autêntica necessidade de reciprocidade, é necessária uma regra coletiva, produto sui generis da vida em comum: é preciso que, das ações e reações dos indivíduos uns sobre os outros, nasça a consciência de um equilíbrio necessário, obrigando e limitando, ao mesmo tempo, o alter e o ego. Este equilíbrio ideal entrevisto por ocasião de cada disputa e cada pacificação, supõe naturalmente, uma longa educação recíproca das crianças, umas pelas outras. (Piaget, 1932/1994, p.239)

Com relação ao segundo caso, ou seja, pensando que cada filho é um, com suas necessidades, suas características, suas dificuldades, o genitor precisa levar em conta todos esses fatores para ser justo. Segundo Piaget: "O igualitarismo simples cede passo diante de uma noção mais refinada de justiça, que podemos chamar a "equidade", a qual consiste em nunca definir a igualdade sem considerar a situação particular de cada um". (Piaget, 1932/1994, p.216). 
Assim a justiça que os pais ensinam aos seus filhos é muito mais aquela que os seus atos revelam na convivência e nas relações diárias, que a justiça pregada ou verbalizada nas lições de moral. Um pai pode falar e não agir conforme as suas palavras? A resposta é não.

A autoridade como tal não poderia ser fonte de justiça, porque o desenvolvimento da justiça supõe a autonomia. Naturalmente, isto não significa que o adulto não tenha nada a ver no desenvolvimento da justiça, mesmo distributiva. À medida que ele pratica a reciprocidade com a criança e prega com o exemplo e não apenas com as palavras, exerce, aqui como em tudo, sua enorme influência. (Piaget, 1932/1994, p.239).

Portanto, trata-se de uma questão de justiça e de reciprocidade: o dever dos filhos de respeitar aos pais implica que os pais respeitem os filhos também. Em outras palavras, a proposta do respeito mútuo, da obediência aos princípios de justiça que nascem das relações de cooperação, é o caminho único para a construção da autonomia. 


\subsection{AUTONOMIA}

\begin{tabular}{|l|}
\hline \multicolumn{1}{|c|}{ AUTONOMIA } \\
\hline 3- Os pais devem sempre considerar as explicações dos filhos. \\
\hline 7- Cabe aos pais tomar as decisões pelos filhos. \\
\hline 13- Os filhos, quando autorizados pelos pais, devem ter suas próprias experiências. \\
\hline 21- Os pais devem ajudar os filhos a refletirem sobre as suas ações ao invés de lhes dar ordens. \\
\hline 25- Nem sempre um pai deve oferecer escolhas aos seus filhos. \\
\hline 27- Os pais devem sempre permitir que seus filhos busquem soluções para os seus próprios problemas. \\
\hline 29- Cabe aos pais darem soluções para as situações difíceis pelas quais passam seus filhos. \\
\hline 32- Não se pode sempre ouvir os filhos. \\
\hline 33- Os pais devem acatar as opiniões dos filhos. \\
\hline 34- Os pais devem substituir os “longos sermões" por poucas palavras. \\
\hline
\end{tabular}

"A autonomia é um poder que se conquista de dentro e que só se exerce no seio da cooperação". (Piaget, 1932/1994). Para ser autônomo, dessa, forma, é necessário que a pessoa tenha as suas próprias experiências. Se as relações com os pais são tão autoritárias que os adolescentes necessitam ser autorizados pelos primeiros para o que quer que desejem fazer, fica vedada a essência da construção da autonomia: a ação do sujeito.

Pensando na autonomia como troca de pontos de vista entre pais e filhos, pode parecer redundante dizer sobre a necessidade de que os pais se disponham a ouvir seus filhos. Essa é a atitude essencial nas relações de cooperação: o ouvir o outro. Parece, entretanto, ser uma dificuldade inerente a todas as relações interindividuais: ouvir e legitimar o pensamento e o sentimento alheio.

Piaget afirma que: "a personalidade implica em cooperação; a autonomia da pessoa opõe-se ao mesmo tempo a anomia, ou ausência de regras e a heteronomia, ou submissão às regras impostas do exterior. Neste sentido, a pessoa é solidária com as relações sociais que mantém e produz". (Piaget, 1964/1986, p.66 e 67).

Que tipos de relações os pais mantêm com seus filhos? Costumam dar ordens, ou ajudam os seus filhos a refletirem sobre as suas ações? Como o fazem? A educação parental se baseia em longos sermões? Interessante que, para a grande maioria dos adolescentes as ordens definitivas e os sermões são atitudes completamente ignoradas. A capacidade de raciocínio abstrato lhes traz a possibilidade de questionamentos. Segundo Elkind (1975, p.109): 
(O adolescente) vê agora muitas alternativas às diretivas paternas e repugna-lhe aceitar essas sem discussão. Quer saber não apenas qual é a posição dos pais, mas também o porquê dessa posição, e está pronto a debater as virtudes da alternativa paterna em comparação com a escolhida por si e seus companheiros.

Portanto, os pais que negligenciam ou ignoram a explicação dos filhos estão caminhando no sentido contrário a autonomia deles, e ao desconsiderarem as opiniões de seus filhos, negam na verdade a nova construção de raciocínio dos mesmos, como se dissessem aos adolescentes: parem já com essa idéia estapafúrdia de querer ser adulto. Os pais perdem dessa forma, a oportunidade sem igual de acompanhar, valorizar e promover esse desenvolvimento psicológico, pois segundo Kamii e Declark (1991, p. 39), “os mais importantes fatores para o desenvolvimento da autonomia das crianças são: oportunidade de trocar pontos de vista com outras pessoas e a possibilidade de tomar decisões".

$\mathrm{Na}$ fase da adolescência, o jovem está buscando a construção da sua personalidade, enquanto a construção de um eu que se percebe diferente dos outros. Especialmente em relação aos pais, o jovem busca intensamente essa separação, na medida em que, durante a infância o "eu" dos pais representou para ele um ego ideal. Cabe aos pais serem então cooperadores com essa construção, afinal, o objetivo máximo dela é exatamente a inserção do jovem no mundo adulto, ou seja, quando os pais definitivamente cumprem o seu papel de educadores para com o mundo, entregando-lhes um recém-chegado saudável e com boas intenções para com esse mundo. (Arendt, 1964/2005).

Doravante, ele (adolescente) não apenas descobrirá os limites que separam o seu eu do de outra pessoa, mas aprenderá a compreender a outra pessoa e a ser compreendida por ela. Assim a cooperação é realmente um fator na criação de... um eu que se consolida sobre normas de reciprocidade e discussão objetiva e que sabe como submeter-se a elas, a fim de fazer-se respeitado. (Hoffman, 1975/1978, p.11)

Portanto, oferecer oportunidades de escolhas aos filhos e permitir-lhes que busquem soluções para os seus próprios problemas, são atitudes coerentes com o adulto que quer cooperar com o seu jovem, ciente de que ele não é mais uma criança e, de que, nessa fase do desenvolvimento já se compreende como "um igual” em relação aos seus pais. Realmente, cabe aos pais acompanhar as tomadas de decisões de seus filhos, orientá-los, aconselhá-los até, enfim, trocar pontos de vista, todavia, jamais tomar as decisões por eles.

Assim, a autoridade adulta, se bem que constituindo, talvez, um momento necessário na evolução da moral da criança, não basta para constituir o senso de justiça. Este só se desenvolve na proporção dos progressos da cooperação e do respeito mútuo, de 
início, cooperação entre as crianças, depois cooperação entre crianças e adultos, na medida em que a criança caminha para a adolescência e se considera, pelo menos em seu íntimo, igual ao adulto. (Piaget, 1932/1994, p.239)

Segunda La Taille (2007, p.13-14) a autonomia, para a moralidade, está ligada a dois sentidos: à questão da liberdade e à questão da autoridade. Conforme suas palavras:

É autônomo quem goza de liberdade, seja porque suas ações não são decorrentes de uma forma de poder exterior ao sujeito, seja porque não é irremediavelmente determinado por forças internas sobre as quais a vontade não exerce influência nenhuma. [...] É autônomo quem legitima regras, princípios e valores morais sem referência a uma fonte que o transcende, sem referência, portanto, a figuras ou instâncias de autoridade.

Portanto, o caminho para a construção da autonomia moral dos adolescentes pressupõe a liberdade e a ausência da autoridade, e cabe mesmo aos pais buscarem uma nova forma de interação com os jovens. $\mathrm{O}$ resultado dos conflitos entre pais e filhos na adolescência deve promover a reconstrução de relações fundamentadas na reciprocidade e na mutualidade.

É por isso que, ao lado do respeito primitivo do inferior pelo superior, ou respeito "unilateral", acreditamos poder distinguir um respeito "mútuo", para o qual tende o indivíduo quando entra em relação com os seus iguais, ou quando os seus superiores tendem a tornar-se seus iguais. O elemento quase material do medo, que intervém no respeito unilateral, desaparece então progressivamente em favor do medo totalmente moral de decair aos olhos do indivíduo respeitado: a necessidade de ser respeitado equilibra, por conseguinte, a de respeitar, e a reciprocidade que resulta desta nova relação basta para aniquilar qualquer elemento de coação. A ordem desaparece no mesmo tempo para tornar-se acordo mútuo, e as regras livremente consentidas perdem seu caráter de obrigação externa. A razão torna-se, desde então, livre para construir seu plano de ação na medida em que permanece racional, isto é, na media em que sua coerência interna e externa está salvaguardada, à proporção em que o indivíduo consegue situar-se numa perspectiva tal que as outras perspectivas concordem com ela. Assim está conquistada a autonomia, além da anomia e da heteronomia.(Piaget, 1932/1994, p. 284)

A citação é extensa, mas guarda em si, um resumo dos conceitos apresentados nesse capítulo, conceitos esses, que nortearam a elaboração do instrumento, objetivo desse estudo. A citação também demonstra que, embora se tenha buscado explanar individualmente a respeito de cada um dos construtos, tendo como objetivo fundamentar teoricamente os itens que os representam, tais assertivas não são excludentes entre si, mas pelo contrário, conforme se expõe na teoria, os fatores respeito, obediência, justiça e autonomia são complementares e se desenvolvem no sujeito de modo concomitante. A interação desses fatores tem como resultado final a construção da autonomia moral do adolescente. 


\section{5- SOBRE A CONSTRUÇÃO DE INSTRUMENTOS DE AVALIAÇÃO PSICOLÓGICA}

\begin{abstract}
A psicometria deve ser concebida como um ramo da Psicologia e que se caracteriza por expressar (observar) o fenômeno psicológico através do número, em vez de pura descrição verbal. Nem por isso ela deixa de ter como ponto central de sua existência, o fenômeno psicológico"
\end{abstract}

Luiz Pasquali

\section{1- Fundamentos da elaboração e validação de testes de avaliação psicológica: da psicometria}

A presente pesquisa tem como objetivo principal a construção e validação de um instrumento de avaliação psicológica. Conforme Pasquali (2003, p. 53): "Em seu sentido epistemológico, Psicometria seria, toda a classe de medida em psicologia”. Assim, seguem abaixo descritos as indicações da psicometria que foram utilizadas nessa investigação para o atendimento do seu objetivo principal: a elaboração da escala das concepções educativas de pais de adolescentes sobre como ser cooperativo com os filhos no processo de construção de sua autonomia moral.

Dessa forma, todos os passos trilhados para a elaboração do instrumento, desde sua concepção, orientada pela teoria do juízo moral de Jean Piaget, passando pela definição da dimensão psicológica a ser investigada, os construtos, os itens, as buscas pela validação, a definição dos processos de validação, a escolha da amostragem, a escolha dos processos de análise teórica e análises estatístiscas descritas ao longo desses capítulos, não representam meramente um método elaborado exclusivamente e ou arbitrariamente para os objetivos dessa investigação, mas são escolhas pautadas em fundamentos da avaliação psicológica, cujas orientações pertinentes ao presente estudo são agora apresentadas.

O objetivo deste capítulo não foi, portanto, realizar uma minuciosa revisão teórica da psicometria, uma vez que seria inviável pela complexidade do tema. O objetivo foi fundamentar teoricamente os procedimentos de análise de dados utilizados por essa investigação de modo a compreender e observar como a psicometria pôde contribuir para a construção e validação de um instrumento de avaliação de concepções educativas sobre o desenvolvimento moral na abordagem piagetiana.

Para Pasquali (2003, p.67), “a psicometria procura explicar o sentido que têm as respostas dadas pelos sujeitos a uma série de tarefas, tipicamente chamadas de itens". Atualmente a psicometria se divide em dois modelos diferentes. A Teoria Clássica do Testes 
(TCT) que vem explicar o resultado final total, ou seja, a soma das respostas dadas a uma série de itens, sendo esses testes, a avaliação de um conjunto de comportamentos; e a Teoria da Resposta ao Item (TRI) que não está interessada no escore total de um teste, mas se interessa por cada item, e portanto, a maneira como o sujeito responde ao item do teste se explica em função de um conjunto de fatores ou traços latentes. Conforme Pasquali (2003, p.83):

Concretamente a TRI está dizendo o seguinte: partir das respostas dadas pelo sujeito, isto é, analisando as suas respostas aos itens especificados, pode-se inferir sobre o traço latente do sujeito, hipotetizando relações entre as respostas observadas deste sujeito com o nível do seu traço latente. Estas relações podem ser expressas através de uma equação matemática que descreve a forma de função que estas relações assumem.

Convém então perguntar o que significa o termo traço latente e o termo item. Quanto à primeira expressão, pode e vem sendo substituída por: construto ou fator (os mais utilizados), variável hipotética, traço de personalidade, tendência, atitude, processo cognitivo, entre outros. Para conceituar então - construto, fator ou traço latente - utiliza-se a citação de Urbina (2007, p.161) : “Um construto é simplesmente aquilo que um autor do teste pretende medir isto é, qualquer entidade hipotética derivada da teoria psicológica, da pesquisa ou observação do comportamento". Ou simplesmente nas palavras de Pasquali (2003, p.56): "Vamos encarar traço latente como processo psicológico".

Mas para que possam ser avaliados, os construtos necessitam ser expressos em comportamentos. Chama-se item os comportamentos que representam os construtos. Sendo essa questão a mais problemática na psicometria: a questão da validade, ou seja a determinação de o quanto e quais itens representam o construto ou traço latente. Conforme as palavras de Pasquali (2003, p. 57):

O parâmetro fundamental da medida psicométrica (escalas, testes, ...) é a demonstração da adequação da representação, isto é, a demonstração do isomorfismo entre a ordenação nos procedimentos empíricos e a ordenação nos procedimentos teóricos do traço valente. Significa demonstrar que a operacionalização do atributo latente em comportamentos (itens) de fato corresponde a este atributo.

As explicações até aqui apresentadas conduzem a constatação de que essa pesquisa utiliza-se então da TRI (Teoria da Resposta ao Item), como modelo para fundamentar a construção e avaliar a validade do instrumento de avaliação psicológica a que se propõem, ou seja, o estudo das relações entre pais e adolescentes, no tocante as concepções dos adultos a respeito dos construtos: obediência, respeito, justiça e autonomia, que segundo a teoria do 
juízo moral de Jean Piaget são fatores necessários à construção da autonomia moral do adolescente. $^{17}$

Esse modelo (TRI) vem substituindo os modelos clássicos de psicometria, por superar algumas dificuldades dos modelos antigos, como o próprio fato de ser um modelo a nível do item e não do teste, e as características dos itens serem independentes da amostra de participantes utilizados por exemplo. Além disso, as etapas de elaboração do instrumento dentro da TRI (Teoria da Resposta ao Item), quando seguidas, já implicam em um tipo de validade que é denominada a Validade de Conteúdo, realizada pela análise teórica dos itens.

Ainda é importante acrescentar que os próprios dados empíricos coletados são utilizados como dados para a análise matemática do modelo, o que significa dizer de forma bem simples que a proporção de sujeitos que de fato acertaram o item, confirma ou não o modelo escolhido. Logo, permite desconfirmação. Esse processo é denominado de Validade de Construto.

Mas, o que é validação de conteúdo ou validado de construto de um instrumento? Segundo Anastasi e Urbina (1997, p.113): "validade de um teste diz respeito ao que o teste mede e com que eficácia ele o faz". Embora, essa conceituação possa parecer extremamente simples, ela é coerente com a TRI (Teoria da Resposta ao Item) sendo que, inclusive, a força dessa teoria conduz a uma utilização cada vez maior da Validade de Construto, sendo que a tendência é que a Validade de Conteúdo e de Critério sejam consideradas apenas aspectos da Validade de Construto.

Segundo Urbina (2007) e Pasquali (2003) a história do parâmetro da validade pode ser dividida em três períodos, sendo que em cada um deles há o predomínio de um dos tipos de validade (propostos pelo famoso trabalho de Cronbach e Meehl, 1955, citado por Pasquali, 2003, p. 159): Validade de Conteúdo, Validade de Critério e Validade de Construto ${ }^{18}$.

O quadro 1 elaborado segundo as definições de Pasquali (2003) e Urbina (2007), conceitua cada uma das categorias:

\footnotetext{
17 A definição teórica de cada construto, bem como a descrição e explicação dos itens que os compõem respectivamente, foram apresentados no quarto capítulo desse texto.

${ }^{18}$ Segundo Urbina (2007, p.160), "um marco importante na evolução do conceito de validade foi a publicação de Techinical Recommendatios for Psychological Tests and Diagnostic Techniques (Recomendações técnicas para testes psicológicos e técnicas diagnósticas, APA, 1954). O primeiro da série de padrões de testagem que foram rebatizados, revisados e atualizados em 1955, 1966, 1974, 1985 e, mais recentemente, em 1999 (AERA, APA, NCME). [...] Os padrões de 1974, reduziram as categorias de validade para três: validade de conteúdo, validade critério e validade de conteúdo.
} 
Quadro 1 - Tipos de validade utilizada pela testagem psicológica

\begin{tabular}{c|l|}
\hline CATEGORIA & \multicolumn{1}{c|}{ CONCEITO } \\
\hline $\begin{array}{c}\text { Validade de } \\
\text { construto }\end{array}$ & $\begin{array}{l}\text { A validade de construto ou de conceito é considerada a forma mais } \\
\text { fundamental de validade dos instrumentos psicológicos e com toda a } \\
\text { razão, dado que ela constitui a maneira direta de verificar a hipótese da } \\
\text { legitimidade da representação comportamental do traço latente. }\end{array}$ \\
\hline $\begin{array}{c}\text { Validade de } \\
\text { critério }\end{array}$ & $\begin{array}{l}\text { Concebe-se como validade de critério de um teste o grau de eficácia } \\
\text { que ele tem em predizer um desempenho específico de um sujeito. O } \\
\text { desempenho do sujeito torna-se, assim, o critério contra o qual a } \\
\text { medida obtida pelo teste é avaliada. As técnicas para a avaliação do } \\
\text { desempenho do sujeito são independentes do próprio teste que se quer } \\
\text { avaliar. }\end{array}$ \\
\hline $\begin{array}{c}\text { Validade de } \\
\text { conteúdo }\end{array}$ & $\begin{array}{l}\text { A validação do conteúdo envolve a revisão crítica e o exame de } \\
\text { conteúdo do teste a partir da investigação da relevância do conteúdo do } \\
\text { teste para um domínio específico e a partir da sua representatividade } \\
\text { em relação às especificações do domínio que ele pretende cobrir. } \\
\text { Portanto, a validade de conteúdo de um teste é praticamente garantida } \\
\text { pela técnica de construção do mesmo. }\end{array}$ \\
\hline
\end{tabular}

Por isso que, atualmente, devido o impacto da TRI (Teoria de Resposta ao Item), com sua insistência no traço latente, a Validade de Construto é considerada uma das perspectivas mais atuais dos estudos da análise da validade em testagens psicológicas. Quanto a Validade de Critério, segundo Pasquali (2003, p. 188), embora tenha sido utilizada para a validação de alguns métodos famosos, acaba sendo inviabilizada a partir de dois argumentos: depois de meticulosa elaboração de um teste parece não ter sentido buscar outras medidas para o mesmo objetivo e ainda ter que comprovar a validade da medida desses outros testes utilizados como critério. E, finalmente, conforme indica o quadro 1, as técnicas de construção do instrumento já viabilizam um dos passos da validação que é a Validade de Conteúdo.

Para Anastasi (1986, p.3):

O processo de validação começa com a formulação de definições detalhadas do traço ou construto, derivadas da teoria psicológica, pesquisa anterior, ou observação sistemática e análises do domínio relevante do comportamento. Os itens do teste são então preparados para se adequarem às definições do construto. Análises empíricas dos itens seguem selecionando-se finalmente os itens mais eficazes da amostra inicial de itens. 
O quadro 2 apresenta as etapas para a elaboração de um instrumento de avaliação psicológica, apontando conjuntamente as fases do processo de Validação de Conteúdo do instrumento. ${ }^{19}$ Esse quadro está fundamentado nos textos de Pasquali (2003) e Urbina (2007).

Quadro 2- Etapas para a elaboração de um instrumento de avaliação psicológica

\begin{tabular}{|c|l|}
\hline $\begin{array}{c}\text { Definição do } \\
\text { domínio }\end{array}$ & $\begin{array}{l}\text { Definir os objetivos ou processos psicológicos que se quer } \\
\text { avaliar. No caso desse trabalho, o domínio são as relações entre } \\
\text { pais e adolescentes com relação ao desenvolvimento da } \\
\text { autonomia moral. }\end{array}$ \\
\hline $\begin{array}{c}\text { Definição dos } \\
\text { construtos }\end{array}$ & $\begin{array}{l}\text { Estabelecimento dos construtos ou fatores a serem medidos, a } \\
\text { partir da respectiva fundamentação teórica e do } \\
\text { desenvolvimento da teoria psicológica sobre esse construto. No } \\
\text { caso desse trabalho, os construtos são: obediência, respeito, } \\
\text { justiça e autonomia. }\end{array}$ \\
\hline \multirow{3}{*}{$\begin{array}{c}\text { Definição dos itens } \\
\text { Análise teórica dos dos }\end{array}$} & $\begin{array}{l}\text { Elaboração dos itens enquanto comportamentos que } \\
\text { representam o construto. Os itens desse trabalho, } \\
\text { itens } \\
\text { fundamentados teoricamente no capítulo anterior desse texto. }\end{array}$ \\
\hline $\begin{array}{l}\text { Análise semântica: verificar se os itens são inteligíveis para } \\
\text { todos os estratos sociais da amostra e verificar se a forma como } \\
\text { o item está descrito, corresponde ao que se espera de sua } \\
\text { compreensão (conforme dados do sétimos capítulo) }\end{array}$ \\
\hline $\begin{array}{l}\text { Análise de juízes: os juízes são peritos na área do construto, e } \\
\text { têm como tarefa dizer se o item constitui uma representação } \\
\text { adequada de qual fator (idem anterior). }\end{array}$ \\
\hline $\begin{array}{l}\text { A versão final do instrumento é aplicada em uma amostra, com } \\
\text { o objetivo de prosseguir com a Análise de Construto (idem). }\end{array}$ \\
\hline Definição do \\
instrumento
\end{tabular}

Com relação à Validação de Construto, Pasquali (2003, p.163) afirma que a lógica da elaboração do instrumento conduz a utilização de análises do tipo análise fatorial confirmatória ( Confirmatory Factor Analysis - CFA) ${ }^{20}$, que procura identificar nos dados empíricos os construtos previamente operacionalizados pelo instrumento. Segundo o autor, havia uma tendência anterior de utilizar as técnicas estatísticas para "salvar a teoria psicológica”. Entretanto, esse não é com certeza, o caminho mais adequado:

É preciso primeiramente, fazer e avançar a teoria psicológica (dos construtos) e apelar, em seguida, à Estatística para auxiliar a tomar decisões mais objetivas sobre a demonstração de hipóteses psicologicamente significativas e relevantes, estas

19 Os passos da elaboração do instrumento dessa pesquisa, bem como todo o processo de busca de tendências de validade de conteúdo, serão apresentados, no sétimo capítulo.

${ }^{20}$ Segundo Pasquali (2003, p. 174): “A validade de construto de um teste é determinada pela grandeza das cargas fatoriais (que são correlações que vão de $-1 \mathrm{a}+1$ ) das variáveis (itens) no fator, sendo aquelas a representação comportamental desse fator, que, por sua vez, é o traço latente para o qual elas foram inicialmente elaboradas como representação empírica". 
deduzidas da teoria psicológica e não levantadas intuitivamente e aleatoriamente. (Pasquali, 2003, p. 166).

Ainda se pode afirmar que existem vários caminhos para a validade de construto. Como a presente pesquisa faz uso da opção da Análise Fatorial Confirmatória, definida anteriormente pelos quadros acima, opta-se por descrevê-la já que foi esse o instrumento de análise de construto utilizado por esse trabalho. Além disso, segundo a literatura do campo da psicometria as "análises confirmatórias são mais sofisticadas do ponto de vista metodológico" (Urbina, 2007, p. 177) e por que "os exemplos desse tipo de trabalho estão se tornando cada vez mais abundantes tanto na literatura psicológica quanto nas seções de validade dos manuais de teste". (Urbina, 2007, p. 182).

Uma vez apresentados os princípios da psicometria que fundamentaram teoricamente a construção e elaboração do instrumento da presente pesquisa, importa ainda discorrer a respeito das justificativas para a escolha da elaboração de um novo instrumento, do tipo Escala ordinal de Likert.

A idéia de medida não pode ser contrária ao referencial teórico. Jean Piaget (1926) elaborou o método clínico como instrumento para investigar o processo de construção do desenvolvimento psicológico. Conforme, se sabe, uma das grandes críticas aos testes, conforme a Teoria Clássica dos Testes (TCT), era o fato de que importava mais a precisão do teste, dada pela estatística, do que a própria teoria psicológica que o fundamentava. (Pasquali, 2003, p.160).

Todavia, a Teoria da Resposta ao Item (TRI) favorece uma nova forma de teorizar a psicometria, que prevê exatamente a busca de uma medida para os processos psicológicos. Assim, uma vez, com o acesso a esse tipo de ferramenta, foi possível pensar em investigar as concepções de pais de adolescentes a respeito dos construtos (obediência, respeito, justiça e autonomia) seguindo rigorosamente os passos previstos pela teoria da avaliação psicológica, garantindo o rigor científico de uma análise quantitativa e assumindo "a Estatística, como é legítimo, o papel de testagem de hipóteses psicológicas formuladas pela teoria psicológica e não o papel de criar ela (Estatística) as hipóteses psicológicas (a posteriori)”. (Pasquali, 2003, p. 175). 


\section{2- Os instrumentos de investigação moral}

O problema dessa pesquisa requisita uma discussão metodológica envolvida na mensuração das relações de moralidade: Quais as concepções educativas dos pais a respeito da sua participação na construção da autonomia moral dos seus filhos adolescentes? Assim para se responder essa questão faz-se necessário compreender o que pensam os pais no que diz respeito às relações de obediência, respeito, justiça e autonomia que estabelecem com os seus filhos adolescentes. O objetivo principal da presente pesquisa é, portanto, a elaboração e construção de um instrumento de medida para essa questão.

Ao fazer essa opção, esse trabalho se insere nas discussões a respeito do significado e da medida do desenvolvimento moral. Todavia, o objetivo desse capítulo é apresentar brevemente os principais instrumentos de medida do desenvolvimento moral já existentes, bem como algumas considerações a respeito desses instrumentos. A fundamentação teórica desses instrumentos baseia-se na teoria de julgamento moral de Kohlberg (1964, 1969, 1971, 1984), sendo que o primeiro dos instrumentos apresentados foi elaborado pelo próprio autor, e conforme as palavras de Lind (2000, p.399): "Kohlberg estabeleceu as bases para a mensuração objetiva do desenvolvimento moral”.

Dentre os instrumentos mais conhecidos e utilizados no Brasil (Koller e outros, 1994), segundo a fundamentação teórica kohlberguiana estão:

- MJI: Entrevista de Julgamento Moral de Kohlberg (Colby e Kohlberg, 1987), constitui-se de três dilemas morais. Embora permaneça no formato de entrevista estruturada com questões abertas, o instrumento foi reavaliado sucessivas vezes, como forma de tornar a avaliação objetiva e fidedigna.

- DIT: Defining Issues Test (Rest e col., 1974) foi elaborado com a finalidade de se obter uma medida mais objetiva do julgamento moral. São apresentadas 12 afirmações que o sujeito deve avaliar, segundo o grau de importância que ele daria a esses fatores na tomada de decisão sobre o dilema proposto. É mais utilizado do que o MJI devido à maior facilidade de apuração dos dados. No Brasil esse instrumento foi adaptado por Bzuneck (1979) que o denominou “Teste de Julgamento de situações" e Camino e Luna (1989), que o intitularam de "Opiniões sobre Problemas Sociais". 
- SROM: Sociomoral Reflection Objective Measure (Gibbs, 1984) gera escores de maturidade moral. Tratam-se de dois dilemas morais de Kohlberg, seguidos de 16 perguntas do tipo múltipla escolha.

Quanto ao DIT, existe uma nova versão americana elaborada por (Rest \& Narvaez, 1998). Segundo Shimizu (2004, p. 6) que apresentou um artigo no qual avaliou a fidedignidade do DIT- 2 e o comparou com o DIT:

Os estudos feitos até o momento mostram que a nova versão é mais moderna, pois o instrumento é mais curto, possui instruções mais claras e mais precisas, invalida um número menor de sujeitos pelo teste de não confiabilidade e parece produzir uma tendência sutilmente mais forte de validade e confiabilidade.

Thoma (2005, p.88) que apresentou um artigo revisando as pesquisas realizadas a respeito do Defining Issues Test (DIT), explica que as recentes pesquisas sobre o teste promovem um distanciamento da teoria dos estágios de Kohlberg, por utilizarem a noção de esquema moral, e, ao mesmo tempo, reafirmam através dos seus dados empíricos algumas das principais predições da teoria kohlberguiana, como a crença de que os juízos morais são cognitivos e desenvolvimentistas.

Outro instrumento foi apresentado por Lind (2000) e intitulado Teste do Juízo Moral (MJT). Segundo o autor, tal instrumento foi desenvolvido com o objetivo de prover um critério de validade para o avanço da pesquisa e da educação moral. Para ele, o MJT é piagetiano, e, partindo dessa abordagem teórica aponta algumas deficiências nos instrumentos de Kohlberg e Rest, afirmando a incompatibilidade teórica com Piaget. Conforme suas palavras:

O MJT é piagetiano na medida em que confronta os sujeitos com dilemas comportamentais (apresentados na forma de uma história na qual os protagonistas tem que resolver um conflito entre dois cursos de ação opostos) e não com situações rotineiras. Como qualquer outra proficiência, a competência do juízo moral apenas se revelará se desafiada por uma tarefa real. (Lind, 2000, p406).

Todos esses instrumentos, com exceção desse último, têm como objetivo principal, investigar o juízo moral dos participantes, avaliando o nível de julgamento moral, fundamentados na teoria de Kohlberg (1981, 1984, 1987). Conforme as palavras de Lukjanenko (2001), sobre os referidos instrumentos:

Partindo dos instrumentos que se pôde ter em mãos: o MJI, o DIT, e o SROM, constatou-se que todos partem da categorização de respostas nos estádios definidos por Kohlberg, com algumas considerações que parecem não interferir no eixo 
central da teoria do desenvolvimento moral. Todos utilizam dilemas hipotéticos e visam à objetividade, cada qual ao seu modo. (Lukjanenko, 2001, p15).

A autora também desenvolveu um instrumento de investigação moral, intitulado por ela de EDRM - Escala de Disposição e Reciprocidade Moral. Tal instrumento foi fundamentado teoricamente em pressupostos piagetianos que possibilitaram o delineamento do nível de reciprocidade moral dos sujeitos no que diz respeito ao conflito vida e lei. Também promoveu uma aproximação dos pressupostos teóricos piagetianos aos kohlberguianos, procurando verificar se os primeiros eram verificáveis no segundo. (Lukjanenko, 2001, p.42).

A temática da elaboração de instrumentos de investigação moral, como se pôde observar por essa breve exposição dos estudos dos instrumentos, é um campo de pesquisa muito fértil e que prevê a necessidade de novas pesquisas. Segundo Lind (2000, p.400):

Apesar de tudo, eu penso que nós, urgentemente, precisamos de uma nova e verdadeira metodologia cognitivo-cultural para medir competências no juízo moral, e não simplesmente um outro novo teste. Se os problemas de desenvolvimento e educação morais ainda são persistentes, também o são os problemas a respeito do significado e medida do próprio juízo moral.

Essa pesquisa se insere na temática do desenvolvimento e educação morais, mas o objeto de estudo do instrumento que se propôs a elaborar, não é aquele, mensurado pelos instrumentos já existentes, ou seja, avaliar o juízo moral segundo os estágios da teoria de Kohlberg.O objetivo da presente pesquisa não é avaliar o juízo moral de pais de adolescentes, mas avaliar as concepções educativas de pais e mães de adolescentes no sentido da sua participação na construção da autonomia moral dos filhos. Portanto, justifica-se a necessidade da elaboração de um instrumento que garanta a especificidade do objeto da presente pesquisa. 


\section{3- Os instrumentos que avaliam as práticas e estilos parentais}

Existem atualmente mais de 100 instrumentos, devidamente validados, que avaliam as atitudes parentais frente ao processo de socialização da criança e são utilizados para identificar as atitudes educativas que são mais acertadas e promovem o desenvolvimento e a saúde mental da criança e do adolescente. (Holden, 1995). Essas pesquisas fundamentam-se na abordagem comportamental, a qual atribui o comportamento moral e ético essencialmente às contingências ambientais.

A abordagem comportamental se subdividiu em algumas linhas de pesquisa, entre elas a que se intitula teoria da aprendizagem social, sendo Bandura (citado por Maccoby e Martin, 1983, p.7) o seu principal representante. Para o autor, o comportamento moral é aprendido da mesma forma que os outros comportamentos sociais: por meio de operações de reforço e punição e da aprendizagem observacional.

A questão das práticas educativas parentais sempre foi um tema importante para a pesquisa em psicologia do desenvolvimento. Compreender quais são as formas mais adequadas para educar de modo a garantir o progresso do desenvolvimento do jovem e a saúde mental dos adolescentes e dos pais é o principal foco dessa linha de pesquisa. (Steinberg, 2001, p. 7).

Portanto, a idéia de que o processo de educação e socialização da criança e do adolescente depende dos objetivos e valores da família que orientam os pais no processo educativo da criança, das práticas parentais que eles utilizam para educá-la e do estilo parental no qual a educação acontece, favorece uma interpretação da idéia de um modelo que integra vários fatores e que se apresentará como um contexto favorável ou não ao desenvolvimento do adolescente. (Nancy e Steinberg, 1993, p.492).

$\mathrm{Na}$ área de avaliação e medidas, essa abordagem justifica a necessidade da construção e validação de instrumentos que identifiquem as diferentes dimensões do processo de socialização com critérios adequados de mensuração e sirvam como medidas auxiliares de estudo das características familiares. (Benetti e Balbinotti, 2003, p. 104)

A pesquisadora mais reconhecida nessa área temática é Diana Baumrind (1966), por ter sido o seu trabalho a impulsionar o surgimento de um número considerável de pesquisas relacionadas ao que a autora denominou práticas e estilos parentais.

Mas o que são práticas e estilos parentais? 
As práticas parentais podem ser entendidas como o conjunto de comportamentos singulares emitidos pelos pais no processo de educação ou socialização dos filhos, que levam a um resultado comum. (Darling e Steinberg, 1993, p. 492). Os estilos parentais, podem ser entendidos como, o clima emocional, ou contexto dentro do qual, as práticas parentais específicas são implementadas. (Darling e Steinberg, 1993, p. 488)

Portanto, as pesquisas que se desenvolveram a partir dos trabalhos de Baumrind, foram organizando instrumentos, e validando-os na medida, em que cada estudo buscava investigar as relações entre as práticas parentais e outras variáveis.

Segundo Teixeira, Oliveira e Wottrich (2006, p.433):

Em seu conjunto, os estudos sugerem que as práticas parentais de fato estão associadas a diversos indicadores de desenvolvimento psicológico e comportamental na adolescência, tais como auto-estima, depressão, ansiedade, desempenho acadêmico, competência interpessoal, comportamentos agressivos, entre outros.

Por isso o grande número de instrumentos de medidas nessa área. Conforme Holden (1995) os instrumentos em sua maioria se subdividem em três ou mais sub-escalas e o conteúdo diz respeito às "atitudes frente à disciplina e controle" e "atitudes relativas ao afeto".

Desses instrumentos, os mais utilizados no Brasil são: Inventário de Estilos Parentais (Gomide, 2006, p. 53) composto de 42 questões, correspondentes a sete práticas educativas; A Escala de Responsividade e Exigência (Costa e colaboradores, 2000) traduzida e adaptada de Lanborn e outros (1991); Parental Attitude Research Instrument (PARI) estudado por Oliveira, Frizzo e Marin (2000); entre outros.

Os instrumentos de investigação das práticas e estilos parentais são observados ainda, sendo empregados em pesquisas cujos referenciais teóricos são pertencentes a outras abordagens. É o caso, por exemplo, das pesquisas que se fundamentam nos estudos de abordagem sistêmica da família desenvolvidos por Bronfembrener (1993, citado por Shaffer, 2005), que reconhece a família como o primeiro ambiente do qual a criança participa ativamente. Para o autor a reciprocidade, o equilíbrio de poder e o afeto, devem se constituir em características para o relacionamento familiar. Segundo a abordagem sistêmica:

As crianças influenciam o comportamento e as práticas educacionais dos pais, e as famílias são sistemas sociais complexos, ou seja, redes de relacionamentos recíprocas e alianças que estão constantemente evoluindo e que são muito influenciadas pela comunidade e pela cultura. (Shaffer, 2005, p.537) 
A pesquisa de Ceconello, De Antoni E Kroller (2003) exemplifica um caso de pesquisa fundamentada na visão sistêmica de Bronfembrener, mas que utiliza como procedimento de pesquisa, instrumentos oriundos da abordagem de Baumrind (1966). Os autores em questão investigaram o abuso físico no contexto familiar, estabelecendo relações entre essa questão e os diferentes estilos e práticas parentais.

A principal questão envolvida nesses instrumentos diz respeito à unidirecionalidade da socialização. Assim as práticas educativas e ou estilos parentais são definidas como preditivas, por exemplo, de problemas de comportamento e de competência social, como no caso da pesquisa de Salvo, Silvares e Toni (2005). Tal fato, providencia uma determinação do contexto familiar como o processo que direciona e é agente de causalidade de determinados comportamentos, ou transtornos mentais, ou qualidade de desempenho escolar, entre outros.

A concepção teórica comportamental, que fundamenta tais instrumentos, entende que os pais são transmissores dos valores morais nos quais acreditam e, que, a partir da utilização de uma prática parental em detrimento de outra, ensinam conteúdos determinados aos seus filhos. Assim esses instrumentos aprovam ou reprovam a atitude dos pais para com os filhos, mantendo-os reféns de uma categorização prévia. As opções de estilo ou práticas parentais utilizadas pelos pais são, no caso desses instrumentos, responsáveis diretas e unidirecionais de comportamentos pré-estabelecidos, conforme se pode observar pelos resultados das pesquisas que se utilizam desses tipos de instrumentos.

Quanto aos resultados (Oliva, 2004, p.356) apontados por esses instrumentos que investigam estilos e práticas parentais, os autores afirmam, que a tendência observada é que:

- Pais autoritários criam filhos: mais hostis e rebeldes, com pouca confiança em si mesmos, com problemas depressivos;

- Pais autoritativos criam filhos: com maior confiança em si mesmos, com melhor desempenho escolar, com boas atitudes, boa saúde mental, poucos problemas de conduta;

- Pais Indulgentes criam filhos: com problemas de conduta e abuso de drogas, com problemas psicológicos;

- Pais Negligentes criam filhos: com problemas escolares, problemas de ajuste psicológico, muitos problemas de conduta e abuso de drogas.

Esse problema da medida ser unidirecional, vem sendo criticado e discutido segundo alguns argumentos, conforme aponta Lila e outros (2006, p. 165): 
Em relação à causalidade ou agência, os pais não são mais considerados como os únicos agentes socializadores. As crianças não são mais meros sujeitos passivos e começam a tornarem-se agentes ativos no processo de acesso e interpretação das idéias dos seus pais e selecionam aquelas que são mais apropriadas para eles.

Obviamente esses estudos apresentam a sua importância e os seus resultados têm pertinência para a pesquisa a respeito da relação pais e adolescentes, especialmente, devido o montante considerável de pesquisas realizadas até os dias atuais. Entretanto, não podem ser indicadores empíricos, ou referência para o instrumento que essa pesquisa se propôs a elaborar, visto que, existe apriori o respeito à necessidade de que, a escolha dos procedimentos empíricos encontre eco na abordagem teórica, buscando harmonia epistemológica entre teoria e prática.

O principal objetivo dessa pesquisa é, portanto, apresentar o processo de construção e validação de um instrumento de pesquisa que possa investigar as relações entre pais e filhos, avaliando as concepções educativas dos pais a respeito de sua influência na construção da autonomia moral do adolescente. Mas o grande desafio está no fato de que esse instrumento deve conciliar:

- o respeito à teoria que o fundamenta: a teoria do juízo moral de Jean Piaget (1932);

- o rigor científico;

- a possibilidade de investigação de uma amostra significativa (maior número de sujeitos);

- a possibilidade de generalização dos resultados para um nível de abordagem nacional;

- a viabilização de uma análise da significância estatística de variáveis dependentes relacionadas ao processo como: gênero, relação sócio econômica, nível de escolaridade, entre outras variáveis, conforme os objetivos específicos listados no próximo capítulo desse texto;

- e, finalmente, a possibilidade de investigar a tendência das concepções educativas de pais de adolescentes brasileiros em relação a cooperação com a construção da autonomia moral de seus filhos. 


\title{
6 PAIS, ADOLESCENTES E AUTONOMIA: ESCALA DE CONCEPÇÕES EDUCATIVAS
}

\author{
O adulto todo já está na criança, a criança toda também está \\ no adulto. (Piaget, 1932/1994, p.75).
}

\subsection{A pesquisa: problema e objetivos}

A evolução da moralidade dos indivíduos, segundo Piaget (1932/1994), depende das relações que se estabelecem com os outros. O autor afirma que quando os adultos mantêm com as crianças relações de coação, elas são vencidas interiormente pelo poder exacerbado do adulto e não podem dessa forma construir seus próprios pontos de vista, distinguir o que é certo ou errado na própria atitude e na de seus genitores, o que poderia impossibilitar-lhes a superação da moral heterônoma.

Por outro lado, quando o sujeito constrói o respeito mútuo e os princípios de justiça como dever e as regras são fundamentadas em tais princípios e cumpridas por opção racional, atinge-se outro nível de desenvolvimento moral, a autonomia.

Portanto, o interesse dessa investigação foi elaborar um mapeamento das concepções de educação dos pais, especialmente, no que diz respeito aos quatro construtos: obediência, respeito, justiça e autonomia, apresentados por essa pesquisa como fatores responsáveis pela possibilidade da construção da moral autônoma.

A análise dos conceitos e intervenções dos pais em relação às suas atitudes educativas, procurando apontar quais foram as facilidades, as dificuldades, as tendências, os encontros e desencontros dos adultos nas relações com seus filhos adolescentes, permitiu o conhecimento das atitudes educativas dos pais e mães brasileiros.

Os pontos de partida dessa investigação, foram os construtos piagetianos: obediência, respeito, justiça e autonomia, fatores para os quais foram criados itens que puderam avaliar as concepções educativas dos participantes (conforme o quarto capítulo desse texto).

Assim, a presente pesquisa buscou, a partir da construção e validação de um instrumento de avaliação psicológica responder às seguintes questões: 
Quais as concepções educativas dos pais a respeito da sua participação na construção da autonomia moral dos seus filhos adolescentes?

Que variáveis ou intervenções dos pais representam suas concepções a respeito de: obediência, respeito, justiça e autonomia?

O seu principal objetivo foi, portanto:

Construir e validar um instrumento de avaliação psicológica que possibilite investigar as concepções educativas dos pais no processo de construção da autonomia dos seus filhos.

Os objetivos gerais da pesquisa foram:

- Elaborar os itens ou variáveis que constituíram cada constructo: obediência, respeito, justiça e autonomia;

- Demonstrar a validade de conteúdo por meio da análise teórica dos itens (análise semântica e análise de juízes);

- Demonstrar a validade de construto, ou seja a legitimidade da representação comportamental dos construtos, através da Análise Fatorial Confirmatória;

- Apresentar o modelo final do instrumento devidamente validado e comentado

A pesquisa buscou investigar também, como objetivos específicos:

1. As concepções educativas dos pais a respeito dos construtos: obediência, respeito, justiça e autonomia;

2. As relações (quanto à significância estatística) entre: gênero, número de filhos, estado civil, profissão, escolaridade dos pais, renda familiar, idade dos participantes e as respostas aos constructos;

3. As relações (quanto à significância estatística) entre: tipo de escola na qual os adolescentes estudam (pública e privada), lugares pesquisados (regiões sul, norte, nordeste, centro-oeste, sudeste do Brasil) e as respostas aos constructos. 


\subsection{Método da pesquisa}

\subsubsection{Os participantes}

Os participantes desse estudo foram pais e mães, e/ou responsáveis, de adolescentes de 12 a 20 anos de idade. O critério para a definição do número de participantes levou em consideração os seguintes aspectos:

1- O cálculo do tamanho da amostra deve contar com um mínimo de 10 pessoas para cada item da escala (mínimo de 400 sujeitos para essa pesquisa), sendo que, a utilização da Análise Fatorial Confirmatória como técnica de validade dos construtos, "usada como meio de explorar os dados, bem como confirmar hipóteses [...] o que se torna mais legítimo quando se trata de grandes conjuntos de dados e grande número de participantes”. (Dancey e Reidy, 2006, p. 422), é a justificativa dada pela literatura do campo da psicometria e da análise estatística. Desse modo, o cálculo do número da amostra depende da opção da técnica de análise estatística.

2- A amostragem dessa pesquisa buscou atingir o objetivo de uma coleta de dados de nível nacional para que se pudesse de fato considerar a inteligibilidade do instrumento em qualquer região do país e para participantes de qualquer estrato sócio econômico, bem como considerar a amostra generalizável e com representatividade das concepções educativas dos pais brasileiros. Tal objetivo condicionou a busca de um $n$ mínimo de 70 sujeitos para cada região do país (norte, sul, sudeste, nordeste e centro-oeste), e a necessidade da pesquisa ser realizada em escolas públicas e privadas.

3- Seguindo essas características, a técnica de amostragem empregada, foi a amostragem por conveniência, considerada pela literatura da psicometria (Malhota, 2001) como uma técnica acessível, pouco dispendiosa, contado com sujeitos cooperadores e dispostos a participação do projeto.

Dessa forma participaram desse estudo 860 adultos: $20,6 \%$ do sexo masculino e $79,4 \%$ do sexo feminino. Os mesmos foram entrevistados em escolas públicas e privadas, somandose respectivamente: 471 sujeitos cujos filhos estavam matriculados em escolas públicas e 389 sujeitos, cujos filhos estavam estudando em escolas particulares. Os dados demográficos da amostra são descritos na tabela I. 
Tabela I - Estatísticas descritivas dos dados demográficos da amostra

\begin{tabular}{|c|c|c|c|}
\hline Variável & & $\mathbf{N}$ & $\%$ \\
\hline \multirow[t]{2}{*}{ Sexo } & Feminino & 683 & $79,4 \%$ \\
\hline & Masculino & 177 & $20,6 \%$ \\
\hline \multirow[t]{2}{*}{ Escola } & Pública & 471 & $54,8 \%$ \\
\hline & Privada & 389 & $45,2 \%$ \\
\hline \multirow[t]{5}{*}{ número de filhos } & 1 filho & 162 & $18,8 \%$ \\
\hline & 2 filhos & 398 & $46,3 \%$ \\
\hline & 3 filhos & 206 & $24,0 \%$ \\
\hline & 4 filhos & 87 & $10,1 \%$ \\
\hline & Mais de 4 filhos & 7 & $0,8 \%$ \\
\hline \multirow[t]{5}{*}{ renda familiar } & Até 2 sal. mín. & 277 & $32,2 \%$ \\
\hline & 2-10 sal. mín. & 248 & $28,8 \%$ \\
\hline & 5-10 sal. mín. & 159 & $18,5 \%$ \\
\hline & 10 -20 sal. mín. & 116 & $13,5 \%$ \\
\hline & Mais de 20 sal. mín & 60 & $7 \%$ \\
\hline \multirow{5}{*}{$\begin{array}{l}\text { escolaridade dos } \\
\text { pais }\end{array}$} & Sem formação & 193 & $22,4 \%$ \\
\hline & Ensino fundamental & 103 & $12 \%$ \\
\hline & Ensino médio & 279 & $32,4 \%$ \\
\hline & Superior & 207 & $24,1 \%$ \\
\hline & Pós-graduação & 78 & $9,1 \%$ \\
\hline \multirow[t]{5}{*}{ Profissão } & Liberal & 80 & $9,3 \%$ \\
\hline & Educação & 164 & $19,1 \%$ \\
\hline & Técnico & 150 & $17,4 \%$ \\
\hline & Baixa qualificação & 154 & $17,9 \%$ \\
\hline & outros & 312 & $36,3 \%$ \\
\hline \multirow[t]{5}{*}{ Estado civil } & Viúvo & 29 & $3,4 \%$ \\
\hline & Casado & 613 & $71,3 \%$ \\
\hline & Divorciado & 86 & $10,0 \%$ \\
\hline & Solteiro & 115 & $13,4 \%$ \\
\hline & Amasiado & 17 & $2,0 \%$ \\
\hline \multirow[t]{5}{*}{ Idade } & Até 30 anos & 34 & $4 \%$ \\
\hline & 30-39 anos & 317 & $36,9 \%$ \\
\hline & $40-49$ anos & 370 & $43 \%$ \\
\hline & $50-60$ anos & 120 & $14 \%$ \\
\hline & Mais de 60 anos & 19 & $2,2 \%$ \\
\hline \multirow[t]{9}{*}{ Local } & Bahia & 63 & $7,3 \%$ \\
\hline & Espírito Santo & 62 & $7,2 \%$ \\
\hline & São Paulo/interior & 100 & $11,6 \%$ \\
\hline & Mato Grosso do Sul & 142 & $16,5 \%$ \\
\hline & Minas Gerais & 132 & $15,3 \%$ \\
\hline & Santa Catarina & 80 & $9,3 \%$ \\
\hline & Ceará & 111 & $12,9 \%$ \\
\hline & Pará & 95 & $11,0 \%$ \\
\hline & São Paulo/capital & 75 & $8,7 \%$ \\
\hline
\end{tabular}




\subsubsection{Situação experimental}

\section{A. Local}

A pesquisa foi realizada em vários estados brasileiros, representativos das cinco regiões do país, em escolas públicas e particulares, conforme se pode observar na Tabela II que apresenta os dados demográficos das escolas e cidades, estados e regiões nas quais a pesquisa foi realizada.

Tabela II - Estatísticas descritivas da distribuição dos dados por região.

\begin{tabular}{|c|c|c|c|c|c|}
\hline Regiões & Estados & Cidades & Escola & $\mathbf{N}$ & $\%$ \\
\hline \multirow{7}{*}{ SUDESTE } & \multirow[t]{3}{*}{ São Paulo } & Itapira & Pública & 82 & $9,5 \%$ \\
\hline & & São João da Boa Vista & Privada & 18 & $2,1 \%$ \\
\hline & & Carapicuíba & Pública & 75 & 8,7 \\
\hline & \multirow[t]{2}{*}{ Minas Gerais } & São Sebastião do Paraíso & Pública & 52 & $6 \%$ \\
\hline & & Juiz de Fora & Privada & 80 & $9,3 \%$ \\
\hline & \multirow[t]{2}{*}{ Espírito Santo } & \multirow[t]{2}{*}{ Cachoeiro do Itapemirim } & Pública & 33 & $3,8 \%$ \\
\hline & & & Privada & 29 & $3,4 \%$ \\
\hline SUDESTE & 3 estados & 6 cidades & 7 esc & 369 & $42,8 \%$ \\
\hline \multirow{3}{*}{ NORDESTE } & Bahia & Salvador & Privada & 63 & $7,3 \%$ \\
\hline & \multirow[t]{2}{*}{ Ceará } & Cascavel & Privada & 48 & $5,6 \%$ \\
\hline & & Beberibe & Pública & 63 & $7,3 \%$ \\
\hline NORDESTE & 2 estados & 3 cidades & 3 esc. & 174 & 20,2 \\
\hline CENTRO- & Mato Grosso & Campo Grande & Privada & 77 & $8,9 \%$ \\
\hline OESTE & do Sul & & Pública & 65 & $7,6 \%$ \\
\hline C-OESTE & 1 estado & 1 cidade & 2 esc. & 142 & $16,5 \%$ \\
\hline \multirow[t]{2}{*}{ NORTE } & \multirow[t]{2}{*}{ Pará } & \multirow[t]{2}{*}{ Belém do Pará } & Privada & 50 & $5,8 \%$ \\
\hline & & & Pública & 45 & $5,2 \%$ \\
\hline NORTE & 1estado & 1 cidade & 2 esc. & 95 & $11,0 \%$ \\
\hline \multirow[t]{2}{*}{ SUL } & \multirow[t]{2}{*}{ Santa Catarina } & Camboriu & Pública & 62 & $7,2 \%$ \\
\hline & & Itajaí & Privada & 18 & $2,1 \%$ \\
\hline SUL & 1 estado & 2 cidades & 2 esc. & 80 & $9,3 \%$ \\
\hline TOTAL & 8 estados & 13 cidades & 16 esc. & 860 & $100 \%$ \\
\hline
\end{tabular}




\section{B. Instrumento de pesquisa}

O objetivo principal dessa pesquisa foi a construção e validação do instrumento: Escala de Concepções Educativas. Toda a tese se destina a apresentar o processo de construção e validação do instrumento.

Essa versão que aqui se apresenta (Quadro 3), conta com 36 itens e trata-se da Escala de Concepções Educativas que de fato foi aplicada nos 860 participantes, e que aqui se apresenta contando com o crivo da autora.

Esse instrumento é fruto de várias outras versões, que foram elaboradas, conforme todos os procedimentos necessários à construção e validação de um instrumento de avaliação psicológica, de acordo com os passos expostos no quinto capítulo desse trabalho. Os resultados das etapas de validação serão apresentados no próximo capítulo, bem como algumas das diferentes versões assumidas pelo instrumento durante esse processo.

Quadro 3- Escala de Concepções Educativas: versão do instrumento aplicado na amostra de 860 participantes com crivo da autora

Avalie as frases abaixo, atribuindo uma nota de 1 a 7 . Conforme o quadro que se segue:

\begin{tabular}{|c|c|c|c|c|c|c|}
\hline 1 & 2 & 3 & 4 & 5 & 6 & 7 \\
\hline $\begin{array}{c}\text { Discordo } \\
\text { totalmente }\end{array}$ & $\begin{array}{c}\text { Discordo } \\
\text { bastante }\end{array}$ & discordo & $\begin{array}{c}\text { Não } \\
\text { sei }\end{array}$ & concordo & $\begin{array}{c}\text { Concordo } \\
\text { bastante } \\
\text { Discordo }\end{array}$ & $\begin{array}{c}\text { Concordo } \\
\text { Plenamente }\end{array}$ \\
\hline \multicolumn{3}{|c|}{ Discordo } \\
\hline
\end{tabular}

\begin{tabular}{|l|c|}
\hline Frases & Notas \\
\hline 1- Um pai sempre mostra interesse pelas coisas que o filho faz. & $\mathbf{7}$ \\
\hline 2- Um pai nunca deve mexer nas coisas do filho sem pedir permissão. & $\mathbf{7}$ \\
\hline 3- Os pais devem sempre considerar as explicações dos filhos. & $\mathbf{7}$ \\
\hline 4- É fundamental que a ordem dada pelos pais, seja acompanhada de uma explicação. & $\mathbf{7}$ \\
\hline 5- Quando o filho faz alguma coisa errada, o pai deve proibi-lo de fazer algo que ele goste. & $\mathbf{1}$ \\
\hline 6- É fundamental que os pais conversem com seus filhos. & $\mathbf{7}$ \\
\hline 7- Cabe aos pais tomar as decisões pelos filhos. & $\mathbf{1}$ \\
\hline 8- Os filhos desobedientes devem saber que deixam os seus pais tristes. & $\mathbf{1}$ \\
\hline 9- Os pais devem sempre contornar os erros dos filhos para não viverem brigando com eles. & $\mathbf{1}$ \\
\hline 10 - Os pais devem usar ofensas quando necessário para educar seus filhos. & $\mathbf{1}$ \\
\hline 11- Um pai deve sempre se auto-controlar para castigar seu filho. & $\mathbf{7}$ \\
\hline 12- Um pai nunca deve confiar no filho. & $\mathbf{1}$ \\
\hline
\end{tabular}




\begin{tabular}{|c|c|}
\hline 13- Os filhos, quando autorizados pelos pais, devem ter suas próprias experiências. & 1 \\
\hline 14- Um pai não deve sempre justificar para os filhos as suas orientações. & 1 \\
\hline $\begin{array}{l}\text { 15- Os pais devem sempre se esforçar para entender as razões da desobediência dos seus } \\
\text { filhos. }\end{array}$ & 7 \\
\hline 16- Um pai pode punir fisicamente seu filho caso ele faça algo muito errado. & 1 \\
\hline 17- Os pais devem dar palpite em tudo o que o filho faz. & 1 \\
\hline 18- Os pais sempre sabem o que é melhor para o seu filho. & 7 \\
\hline $\begin{array}{l}\text { 19- Um pai que tem dois filhos precisa sempre agir do mesmo modo com os } \\
\text { dois. }\end{array}$ & 3 \\
\hline 20- Um pai nem sempre deve trocar idéias com seus filhos. & 1 \\
\hline $\begin{array}{l}\text { 21- Os pais devem ajudar os filhos a refletirem sobre as suas ações ao invés de Ihes dar } \\
\text { ordens. }\end{array}$ & 7 \\
\hline 22- Um filho sempre deve acatar as ordens dos pais. & 1 \\
\hline 23- Uma boa ameaça costuma resolver uma desobediência. & 1 \\
\hline 24- Um pai deve ajudar seu filho a arcar com as conseqüências dos seus atos. & 7 \\
\hline 25- Nem sempre um pai deve oferecer escolhas aos seus filhos. & 1 \\
\hline 26- As atitudes dos pais para com os filhos são sempre coerentes. & 3 \\
\hline $\begin{array}{l}\text { 27- Os pais devem sempre permitir que seus filhos busquem soluções para os seus próprios } \\
\text { problemas. }\end{array}$ & 6 \\
\hline 28- Os filhos devem obedecer os pais em todas as situações. & 1 \\
\hline 29- Cabe aos pais darem soluções para as situações difíceis pelas quais passam seus filhos. & 3 \\
\hline 30- Os filhos que amam seus pais sempre devem lhes obedecer. & 1 \\
\hline 31- O papel dos pais é ser modelo para sustentar as regras junto aos filhos. & 7 \\
\hline 32- Não se pode sempre ouvir os filhos. & 1 \\
\hline 33- Os pais devem acatar as opiniões dos filhos. & 3 \\
\hline 34- Os pais devem substituir os "Iongos sermões" por poucas palavras. & 7 \\
\hline 35- O pai pode falar e não agir conforme as suas palavras. & 1 \\
\hline 36- Os filhos devem respeitar os pais mesmo que os pais não os res & 1 \\
\hline
\end{tabular}

\subsubsection{Procedimentos}

\section{A. Para a coleta de dados}

A pesquisa utilizou o espaço das escolas para realizar a coleta de dados. Inicialmente realizou-se o contato com as mesmas para apresentação do projeto de pesquisa e da 
documentação necessária. Esse processo foi realizado via e-mails, telefonemas e envio de curriculum vitae e vídeo (ministrando uma palestra) da pesquisadora, além de carta de apresentação do projeto, com assinatura da orientadora. Conforme a aprovação do projeto pela direção do colégio ou escola pública, a instituição optava pela participação da pesquisadora em uma reunião de pais previamente agendada ou organizava um evento no qual os pais eram convidados para comparecerem na escola para participarem do projeto. ${ }^{21}$

Algumas escolas requisitaram ainda para a realização da pesquisa, a apresentação do documento de aprovação do Comitê de ética. Essa pesquisa foi avaliada e devidamente autorizada previamente pelo Comitê de ética de pesquisa com seres humanos do Instituto de Psicologia da Universidade de São Paulo ${ }^{22}$. Todos os 860 participantes da pesquisa, bem como as 16 escolas nas quais a investigação foi realizada assinaram o Termo de consentimento livre e esclarecido ( $c f$ anexo A). Salvaguardou-se a todos os participantes o voluntariado na participação, bem como o direito ao sigilo e a interrupção ou desistência do preenchimento dos questionários.

A aplicação dos dois formulários, fosse aquele com os dados pessoais (com exceção de identificação pessoal), bem como o preenchimento da própria escala de concepções educativas (instrumento de pesquisa) foi realizado coletivamente em ambiente providenciado pelas respectivas instituições (quadra, sala de aula, anfiteatro ou pátio). A aplicação nas 16 escolas foi realizada pessoalmente pela pesquisadora que permanecia junto aos participantes do início ao término do trabalho.

As orientações para o adequado preenchimento da escala das concepções educativas seguiram os seguintes passos:

1- Apresentação da pesquisadora;

2- Orientação e motivação para a colaboração com a pesquisa, que se resumia em dizer sobre a importância da participação dos mesmos em uma pesquisa nacional a respeito do que eles pensam sobre a educação dos seus filhos adolescentes;

3- Instruções para o preenchimento do perfil do respondente;

4- Instruções para o preenchimento correto da escola de Likert, explicando aos participantes que pensassem inicialmente se concordavam ou não com cada frase, e

\footnotetext{
${ }^{21} \mathrm{Na}$ grande maioria das instituições, o fato que propiciou a possibilidade da participação da escola no projeto de pesquisa, foi a disponibilidade da pesquisadora em realizar uma palestra gratuitamente para os pais, após o processo de coleta de dados. Isso aconteceu na grande maioria das instituições pesquisadas, tanto em momentos de reuniões de pais, quanto em reuniões organizadas para a pesquisa, ou seja, os pais participavam da pesquisa e depois vivenciavam um momento de formação.

${ }^{22}$ Esse projeto de pesquisa teve o seu projeto analisado e aprovado, teórica e metodologicamente falando, pelo Comitê de Ética em Pesquisas em Seres Humanos do IPUSP (CEPH-IP), em 18/09/2006.
} 
depois de definido esse aspecto primordial da sua opinião, que mensurassem o quanto (totalmente, bastante, pouco) concordavam ou discordavam, escolhendo a sua nota para a afirmativa, na escala de 7 pontos;

5- Instruções a respeito da nota 4 da escala, ou seja, o ponto neutro, orientando os participantes que poderiam atribuir nota 4 quando estivessem em dúvida a respeito da frase, se não soubessem respondê-la, ou ainda se não quisessem respondê-la;

6- Orientações para o preenchimento total do instrumento (que não deixassem questões sem resposta).

7- Instruções para que o pai ou mãe ou responsável respondesse conforme as suas próprias atitudes e intervenções, colocando-se no lugar do sujeito indeterminado proposto pelo item.

Esse último aspecto da orientação foi bastante polêmico, pois em todos os grupos de participantes sempre surgiu o questionamento se deveriam responder o que achavam certo fazer ou o que realmente faziam.

Especialmente na escola pública de Beberibe, Ceará, aconteceu a participação de algumas mães que não sabiam escrever e os professores se dispuseram a ler e anotar as respostas para tais participantes. Portanto, embora o instrumento fosse escrito, não se negou a participação de participantes analfabetos.

Os procedimentos para a coleta de dados foram os mesmos para todas as escolas: públicas ou privadas.

\section{B. Para a Análise de Dados}

Os procedimentos para análise de dados foram os seguintes:

1. Avaliação qualitativa dos itens levando em consideração os processos psicológicos que se quis avaliar, ou seja, as questões relacionadas à elaboração dos construtos: respeito, justiça, obediência e autonomia, bem a representatividade de cada fator, a partir dos itens que o compuseram. Assim nessa fase, questões como inteligibilidade, representatividade e coerência do item foram analisadas, contando com a participação dos juízes (doutores especialistas em psicologia do desenvolvimento moral e em psicometria, avaliação psicológica e análise estatística);

2. Avaliação da validade de conteúdo. Essa fase contou com a participação de juízes, doutores especialistas em psicologia do desenvolvimento moral. A análise teórica dos itens foi realizada tomando como fundamento a teoria do juízo moral de Jean Piaget. Os 
juízes avaliaram a pertinência de cada item ao seu constructo, bem como a representatividade de tais comportamentos psicológicos enquanto indicadores dos construtos.

3. Avaliação da Validade do Construto. Segundo Hair Jr. et al. (1998) o uso de técnicas estatísticas apropriadas está vinculado aos objetivos desejados. Logo, de acordo com a lógica da elaboração do instrumento, a Análise Fatorial Confirmatória foi considerada a mais adequada forma de validação de construto, por se tratar de um tipo de análise estatística que testa os itens um a um, estabelecendo correlações multivariadas e o estudo das covariâncias, que permite identificar nos dados empíricos, os construtos previamente definidos pelo instrumento. (Pasquali, 2003)

4. O modelo final do instrumento foi avaliado, considerando o processo de construção e validade e buscando uma análise qualitativa dos resultados quantitativos à luz da teoria do juízo moral de Jean Piaget, bem como dos resultados de pesquisas dos últimos dez anos, relacionadas ao tema da relação pais e adolescentes e o desenvolvimento moral.

5. Os resultados obtidos pela pesquisa no território nacional foram discutidos buscando responder aos objetivos específicos da investigação, utilizando ainda testes estatísticos como Kolmogorov Smirnov Test (Levin, 1987) utilizado para a verificação da aderência dos das à distribuição normal e definição dos testes posteriores) e Mann Whitney Test (Siegel, 1979), Anova (Maroco, 2003), Tukey Test, (Maroco, 2003), Kruskal Wallis Test (Siegel, 1979), testes que permitiram investigar a influência de cada variável e sua significância estatística, em relação a si mesmas e aos construtos. 


\title{
7 CONTRUÇÃO E VALIDAÇÃO DA ESCALA DE CONCEPÇÕES EDUCATIVAS: RESULTADOS
}

\begin{abstract}
Sem dúvida, a qualidade dos instrumentos psicológicos é um campo bastante abrangente, que envolve além das revisões periódicas dos instrumentos, a preocupação com a construção e padronização. [...] No Brasil, é relativamente recente a prática de construção de instrumentos, já que por muitos anos, psicólogos brasileiros usaram como recursos de avaliação, instrumentos estrangeiros que não possuíam nenhum estudo a respeito de validade ou precisão com amostras brasileiras. (Noronha e Alchieri, 2005, p. 30).
\end{abstract}

O presente capítulo apresentará os resultados obtidos pela pesquisa, cujo objetivo principal foi a construção e a validação da Escala de concepções educativas dos pais em relação a sua participação na construção da autonomia moral do adolescente. Desse modo os resultados se subdividem em dois capítulos intitulados respectivamente de Validação de Conteúdo $^{23}$ e Validação de Construto ${ }^{24}$.

A Validação de conteúdo apresenta todas as fases de elaboração do instrumento bem como a análise teórica do mesmo, com a avaliação dos juízes, avaliação semântica e os resultados do estudo piloto. Essa parte do capítulo ainda apresenta a última versão do modelo do instrumento, versão essa que foi aplicada nos 860 participantes para que se desse prosseguimento a análise estatística do instrumento.

A Validação de Construto apresenta os resultados da análise estatística, que, através da Análise Fatorial Confirmatória ajustou o modelo inicial validando a pertinência de cada item ao seu construto. O modelo final do instrumento validado então teoricamente e estatisticamente, atendendo ao objetivo principal da pesquisa é apresentado como o resultado final da pesquisa.

\footnotetext{
${ }^{23}$ A conceituação e definição do processo de Validação de Conteúdo e Validação de Construto, segundo as regras da psicometria, estão apresentadas no quinto capítulo deste texto.

${ }^{24}$ Idem.
} 


\section{1- Validade de conteúdo}

\section{a- Definição do domínio, dos construtos e dos itens}

O terceiro capítulo desse texto apresentou os dados de pesquisa a respeito do domínio do instrumento que essa pesquisa se propôs a criar: a relação pais e adolescentes e a construção da autonomia moral. Para a definição dos construtos: obediência, respeito, justiça e autonomia (inicialmente pensou-se também em reciprocidade), a pesquisa utilizou a revisão teórica apresentada no quarto capítulo desse trabalho ${ }^{25}$.

Com base na teoria do juízo moral de Jean Piaget (1932) foram eleitos inicialmente, cinco fatores ou construtos que conduziram a elaboração da primeira versão do instrumento com 47 itens, sendo que a partir da elaboração dessa primeira escala, observou-se a necessidade da construção de um instrumento que a complementasse. Os itens foram compreendidos como dizendo respeito aos conceitos dos pais sobre: respeito, obediência, reciprocidade, autonomia e justiça, investigando o seu juízo moral a respeito deles. Porém como de fato os colocavam em prática, ou seja, quais seriam as suas intervenções junto aos filhos para providenciar a efetivação de seus julgamentos parecia não estar contemplado, por isso foram elaboradas cinco situações de dilemas cotidianos com as suas respectivas possibilidades de respostas.

A primeira versão do instrumento apresentada no quadro 4 contava com cinco construtos mensurados em duas escalas. Nessa primeira fase de elaboração do instrumento, o mesmo foi apresentado a cada juiz (especialista em instrumentos de avaliação psicológica e ou em desenvolvimento moral), na sua forma original, ou seja, os itens que representam o construto, seguidos da situação concreta respectiva a cada construto também. A pesquisadora realizou reuniões individuais com cada juiz com o objetivo de uma primeira análise qualitativa do instrumento e de ouvir sugestões e orientações, conforme a experiência e conhecimento de cada um. Dessa forma, questões como compreensão do item, adequação do item e do construto, organização do instrumento e outros temas foram apontados pelos participantes e são descritas logo após a apresentação da primeira versão do instrumento.

${ }^{25}$ O quarto capítulo apresenta toda a reflexão do pesquisador sobre a leitura teórica, enquanto esse capítulo pretende apresentar todo trabalho reflexivo do pesquisador sobre o instrumento. 
Quadro 4 - Instrumento na sua primeira versão

\begin{tabular}{|c|c|}
\hline RES & SITUAÇÃO \\
\hline $\begin{array}{l}\text { 1- Respeitar o filho é sempre mostrar } \\
\text { interesse pelas coisas que ele faz. } \\
2-\quad \text { O pai deve sempre conversar com o filho, } \\
\text { considerando o seu ponto de vista, em todas as } \\
\text { situações. } \\
\text { 3- O pai que respeita seu filho dá palpite em } \\
\text { tudo o que ele faz. } \\
4-\quad \text { O pai que respeita o filho não mexe em } \\
\text { suas coisas sem pedir permissão. } \\
5-\quad \text { O pai que respeita o filho confia nele. } \\
6-\quad \text { O pai que respeita seu filho é sempre } \\
\text { constante em suas intervenções junto a ele e não } \\
\text { muda de postura conforme a situação ou o } \\
\text { próprio estado de humor. } \\
7-\quad \text { O pai que respeita o filho deve ensinar o } \\
\text { que é certo e o que é errado. } \\
\text { 8- Respeitar os pais é assumir seus valores } \\
\text { e seguir às suas ordens. } \\
9-\quad \text { Os pais devem fazer todo o possível para } \\
\text { trocar pontos de vista com os filhos. } \\
\text { 10- O pai que respeita o filho sempre explica } \\
\text { a razão de ser das suas ordens. }\end{array}$ & $\begin{array}{l}\text { O adolescente chega em casa atrasado, cerca de } \\
3 \text { horas, depois do colégio, sendo que essa } \\
\text { situação tem se repetido há dias. O pai deve } \\
\text { intervir dizendo: } \\
\text { a- Você deve ser surdo, já lhe falei mil vezes o } \\
\text { horário que você deve chegar em casa. } \\
\text { b- Se você se atrasar novamente não sairá no } \\
\text { final de semana. } \\
\text { c- Quando eu tinha a sua idade respeitava as } \\
\text { ordens dos meus pais e jamais lhes dei tanto } \\
\text { desgosto e preocupação como você me faz. } \\
\text { d- Eu já havia avisado você para não se atrasar } \\
\text { novamente, agora você passará essa tarde } \\
\text { cuidando do seu irmãozinho e ficará uma semana } \\
\text { sem internet. } \\
\text { e- Penso que deva ser difícil para você deixar a } \\
\text { sua turma, quando está se divertindo, mas por } \\
\text { outro lado eu me sinto muito preocupado quando } \\
\text { você se atrasa. } \\
\text { f- O que você tem a me dizer sobre essa } \\
\text { situação? Como pode resolver isso? } \\
\text { g- Vamos ver se temos algumas idéias que sejam } \\
\text { úteis para nós dois. Escrevamos nossas } \\
\text { sugestões e vamos decidir e planejar uma boa } \\
\text { solução. }\end{array}$ \\
\hline
\end{tabular}

\section{RECIPROCIDADE}

11- O dever dos filhos de respeitar aos pais corresponde à exigência de que os pais os respeitem também.

12- Os pais devem sempre apresentar aos filhos as justificativas racionais das regras e dos limites.

13- As acusações, as humilhações e as ofensas dos pais provocam a culpa e a revolta nos filhos.

14- Os pais devem sempre auxiliar os filhos a organizar seus argumentos,

15- Os pais devem sempre dar aos filhos a possibilidade de expressar suas idéias.

16- Os pais devem sempre auxiliar os filhos a refletirem sobre os seus atos.

17- Os pais devem conduzir a educação dos filhos de tal modo que os mesmos pensem e ajam como eles próprios.

Os pais devem saber tudo a respeito de seus filhos: estudo, lazer, amigos, pensamentos e sentimentos.

18- Os filhos devem consultar os pais sobre suas decisões.

\section{SITUAÇÃO}

A adolescente se apropria da blusa preferida da mãe, sem a sua permissão. Além de usá-la sem permissão, perde a blusa. A mãe deve intervir dizendo:

a- Vá agora ao seu guarda-roupa, escolha uma de suas blusas preferidas, pois eu a doarei a uma instituição de caridade.

b- Não se pega as coisas dos outros sem pedir. O que fará agora para restituir o prejuízo que me causou?

c- Eu já cansei de lhe dizer para não pegar minhas coisas, pois você não tem zelo por nada, nem por si mesma.

d- O que você precisa aprender é que não deve fazer para os outros o que não quer que façam a você. Você gostaria que eu perdesse uma blusa sua?

e- Como você é responsável! Que menina mais cuidadosa! Dá até gosto emprestar coisas para você!!

f- A partir de hoje você ficará bem longe do meu quarto, pois eu o manterei trancado até que me diga que posso confiar em você.

g- Temos um problema aqui: você usou a minha blusa sem autorização e a perdeu. $\mathrm{O}$ que tem a me dizer sobre isso? 


\begin{tabular}{|c|c|}
\hline OBEDIÊNCIA & SITUAÇÃO \\
\hline $\begin{array}{l}\text { 19- A ordem ou a repreensão dada são } \\
\text { acompanhadas da explicação de sua razão de } \\
\text { ser, baseadas nas conseqüências da infração. } \\
20-\quad \text { As regras e os limites são impostos pelos } \\
\text { pais que devem exigir o seu cumprimento. } \\
21-\quad \text { Os pais devem se utilizar de estratégias } \\
\text { que façam os filhos entenderem que, quando } \\
\text { desobedecem entristecem e decepcionam os } \\
\text { seus pais. } \\
22-\quad \text { Os filhos devem sempre obedecer os } \\
\text { pais. } \\
23-\quad \text { O pai deve sempre saber o que é melhor } \\
\text { para o seu filho. } \\
24-\quad \text { Os pais devem repetir sempre as regras } \\
\text { para os seus filhos. } \\
25-\quad \text { Os limites e as regras são legitimados } \\
\text { em função da força e do prestígio de quem os } \\
\text { coloca: aos pais cabe desempenhar esse papel. } \\
26-\quad \text { Uma boa ameaça costuma resolver uma } \\
\text { situação de desobediência. } \\
27-\quad \text { Os filhos precisam temer os seus pais. } \\
28-\quad \text { O filho que ama a seu pai sempre o } \\
\text { obedece. }\end{array}$ & $\begin{array}{l}\text { Uma mãe tem dois filhos adolescentes. Um é } \\
\text { obediente e o outro não. Avalie as intervenções } \\
\text { da mãe. } \\
\text { a- A mãe deve sempre privilegiar o filho } \\
\text { mais obediente, dando-lhe por exemplo, os } \\
\text { melhores presentes. } \\
\text { b- A mãe deve ressaltar o comportamento } \\
\text { adequado do filho obediente, para que o outro } \\
\text { aprenda a imitá-lo. } \\
\text { c- A mãe deve punir o filho que desobedece } \\
\text { dando-Ihe uma surra. } \\
\text { d- A mãe deve ameaçar cortar a mesada do } \\
\text { filho desobediente. } \\
\text { e- A mãe deve sempre tratar com igualdade } \\
\text { aos seus dois filhos. } \\
\text { f- A mãe não deve comparar os seus filhos, } \\
\text { pois cada ser humano é único. } \\
\text { g- Os filhos não devem ser obedientes aos } \\
\text { pais e sim obedientes a regras fundamentadas } \\
\text { em bons princípios. }\end{array}$ \\
\hline
\end{tabular}

\begin{tabular}{|c|c|}
\hline AUTONOMIA & SITUAÇÃO \\
\hline 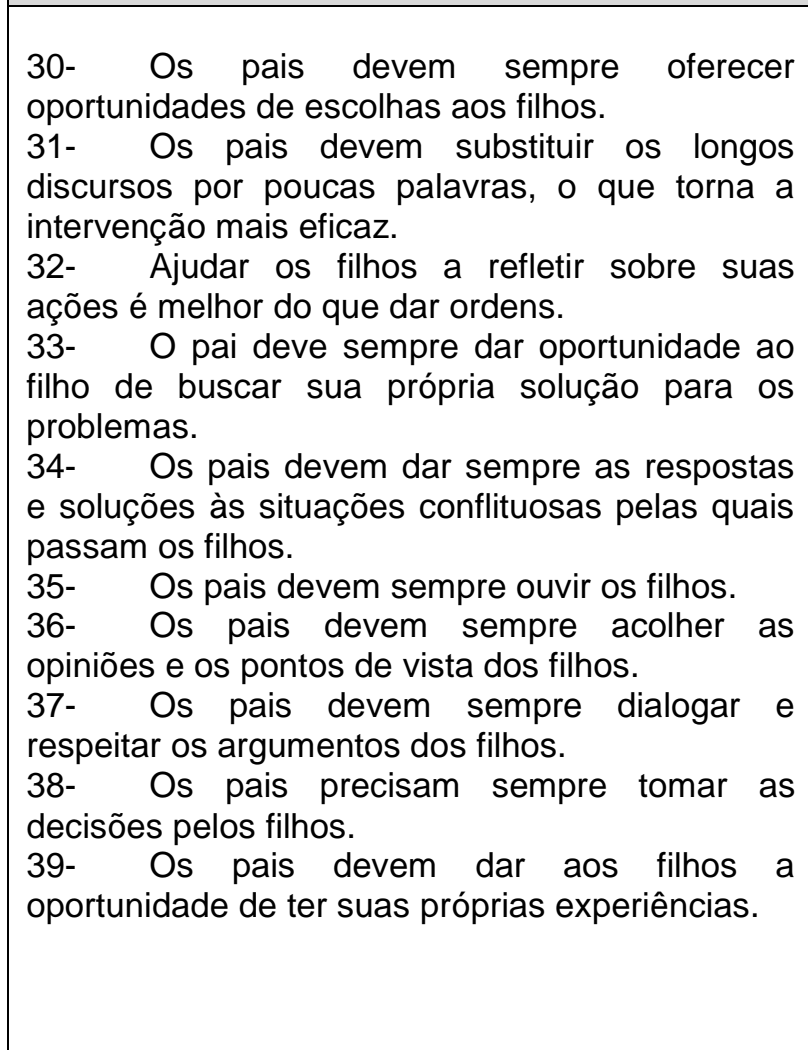 & $\begin{array}{l}\text { O adolescente demonstra-se irritadiço e } \\
\text { angustiado pois não consegue estudar: não } \\
\text { cumpre os prazos de entrega das tarefas e não } \\
\text { consegue se concentrar nos estudos. O pai deve } \\
\text { intervir dizendo: } \\
\text { a- O que é melhor para você? Que nos sentemos } \\
\text { para estudar juntos ou prefere trabalhar sozinho } \\
\text { e depois tirar suas dúvidas? } \\
\text { b- Vejo que está sendo difícil para você se } \\
\text { concentrar. Como gostaria que eu o ajudasse? } \\
\text { c- Você escolhe: ou estuda pelo menos uma } \\
\text { hora por dia religiosamente, ou ficará até a } \\
\text { próxima avaliação. } \\
\text { d- Temos um problema aqui: você tem dúvidas e } \\
\text { não está conseguindo se concentrar. Quer } \\
\text { conversar sobre isso? } \\
\text { e- Na sua idade eu cumpria com as minhas } \\
\text { obrigações, e olha que, além de estudar eu } \\
\text { trabalhava fora também. Você a partir de hoje vai } \\
\text { se matricular em aulas de reforço. } \\
\text { f- Você acha que poderia encontrar alguém que } \\
\text { pudesse lhe ajudar com essa matéria? Ou será } \\
\text { que você teria uma outra solução? } \\
\text { g- Olhe bem, com esse sua força de vontade é } \\
\text { melhor que se prepare para a recuperação nessa } \\
\text { disciplina. }\end{array}$ \\
\hline
\end{tabular}




\begin{tabular}{|c|c|}
\hline JUSTIÇA & SITUAÇÃO \\
\hline $\begin{array}{l}40-\text { Quando o filho faz algo errado é justo } \\
\text { que o pai o puna, proibindo-o de fazer algo que } \\
\text { ele gosta. } \\
41 \text { - Os pais devem sempre punir os seus } \\
\text { filhos quando eles descumprem as suas ordens. } \\
42-\quad \text { O pai que não concorda com o } \\
\text { comportamento do filho deve sempre mostrar-lhe } \\
\text { isso, castigando-o fisicamente. } \\
43-\quad \text { Um pai que tem dois ou mais filhos } \\
\text { precisa ter com cada um deles a mesma atitude. } \\
44-\quad \text { Os pais devem ser sempre exemplo dos } \\
\text { valores que querem ensinar aos filhos. } \\
45-\quad \text { As condutas dos pais falam mais do que } \\
\text { suas próprias palavras. } \\
46-\quad \text { Os filhos devem experimentar a justiça } \\
\text { nas suas relações cotidianas com os pais. } \\
47-\quad \text { Os pais devem ajudar seus filhos a arcar } \\
\text { com as conseqüências de seus atos. }\end{array}$ & $\begin{array}{l}\text { Um pai tinha dois filhos. Um sempre resmungava } \\
\text { quando ele lhe pedia para fazer uma compra, o } \\
\text { outro não gostava de fazê-lo, mas ia sem dizer } \\
\text { nada. Avalie a intervenção do pai. } \\
\text { a- O pai deve sempre pedir ao filho que não } \\
\text { reclama para realizar a compra. } \\
\text { b- O pai não deve abusar da generosidade } \\
\text { do filho gentil. } \\
\text { c- O pai deve punir o filho resmungão, } \\
\text { dizendo-lhe que a solidariedade é um valor } \\
\text { essencial a uma boa pessoa. } \\
\text { d- O pai deve apresentar a sua necessidade } \\
\text { aos dois filhos e pedir que eles encontrem juntos } \\
\text { um modo de decidir quem vai as compras. } \\
\text { e- O pai deve presentear o filho gentil e } \\
\text { privar o resmungão de algo que ele goste. } \\
\text { f- } \quad \text { Quando o filho resmungão pedir algo ao } \\
\text { pai, o mesmo deve se negar a contemplar-lhe. } \\
\text { g- O pai deve questionar o filho gentil sobre } \\
\text { o porquê sempre acata as ordens, ainda que não } \\
\text { o deseje. }\end{array}$ \\
\hline
\end{tabular}

Os cinco juízes apontaram sugestões e questionamentos a respeito do formato das escalas e do próprio conteúdo dos itens, dando procedimento a uma avaliação qualitativa do instrumento. Segue um resumo desses apontamentos, uma vez que eles foram decisivos para a elaboração dos itens, antes da análise teórica dos mesmos.

- Sugeriram que se evitassem as frases que poderiam ser consideradas pelos participantes como "politicamente corretas", isto é, não resultassem na discriminação da resposta certa ou errada para o sujeito. Assim todas as frases foram revistas no intuito de evitar tal característica;

- As frases deveriam ser coesas e diretas;

- Sugeriram que se elaborassem afirmativas fortes e provocativas que providenciassem o questionamento, no participante, sugerindo inclusive a utilização de vocábulos como sempre e nunca, normalmente considerados evitáveis pela literatura. (Prieto \& Delgado, p.127). Tal sugestão foi acatada;

- Outra sugestão foi a inversão de alguns dos itens, de modo que por hora a resposta correta fosse concordo e em outros momentos fosse discordo, para evitar que o participante pudesse gabaritar as respostas tornando-se indiferente aos itens. Essas providências também foram acolhidas; 
- Com relação ao formato do instrumento contando com uma escala para o estudo dos conceitos dos pais sobre os referidos construtos e uma escala para a avaliação das condutas dos pais, os professores afirmaram que tal formato era criativo e adequado;

- Alguns itens da primeira escala de juízo moral, conforme estavam redigidos, representavam na verdade uma avaliação da realidade, e dessa forma, foram sugeridas alterações em suas formulações, uma vez que o segundo instrumento continha já itens cujo objetivo era exatamente a mensuração da realidade. Foram transformados todos os itens que descaracterizavam o juízo moral;

- Com relação aos cinco fatores que compuseram a escala foi apontado que o fator 'reciprocidade' não seria condizente com a investigação da relação entre pais e filhos, que não supõem a reciprocidade, mas, uma relação assimétrica, por se tratar de uma relação com autoridade e não uma relação entre pares. $O$ construto da reciprocidade foi eliminado do instrumento e observou-se que os itens que o compunham tinham itens similares a outros construtos;

- A situação concreta da segunda escala que devia tratar de uma situação de respeito foi apontada como uma situação que tratava de um domínio convencional e não moral. Essa situação foi eliminada do instrumento;

- Como era apontado no título inicial do trabalho que se tratava de uma investigação do papel dos pais na construção da personalidade moral dos filhos, foi sugerido que para que o instrumento pudesse investigar a personalidade moral, faltava no trabalho um construto ou fator que tratasse do aspecto afetivo da moralidade, ou seja, do querer moral senão a proposta do trabalho dizia respeito à construção da autonomia moral. A opção foi pela investigação da construção da autonomia moral;

- Questionou-se o porquê de sete possibilidades de respostas como era proposto pela primeira versão do instrumento. A sugestão foi acatada inicialmente, e a decisão foi por uma opção de 4 respostas, sem a possibilidade do número ímpar de alternativas, na qual o ponto neutro poderia significar tanto a dúvida do participante, quanto o seu não comprometimento. Essa opção foi inicialmente acatada;

- Sugeriu-se o cuidado para que os itens não tivessem dois princípios pois isso encaminharia a tendência do item ao fracasso, uma vez que não se poderia saber qual dos princípios seria realmente avaliado pelo participante. Todos os itens que apresentavam essas características foram desmembrados e reescritos; 
- Indicou-se que se procedesse à verificação teórica de cada um dos itens, pois o participante poderia ter dúvida no item, mas o pesquisador não, pois precisava saber a resposta certa: elaboração do crivo. (Günther, p.252).

- Sugeriu-se que se revisse o formato de alguns itens, pois poderiam desencadear "erros" ou não concordância com o fator na análise fatorial, além de que poderiam induzir a dificuldade de compreensão do item por parte do sujeito. A escala deveria ser toda redigida na terceira pessoa. Vários itens foram redigidos e revistos segundo as várias sugestões dadas pelos juízes, buscando apresentá-los na sua versão mais coesa e com o vocabulário acessível;

- Observou-se também o cuidado em não se utilizar frequiência do ato (sempre, nunca) nos itens, especialmente, em itens muito fechados. Todavia a perspectiva teórica que norteia a construção da escala pode validar essa forma, já que causará no participante a necessidade de refletir a respeito do item e, também, o forçará a assumir a sua opinião. Ainda que as duas sugestões tenham sido dadas, ou seja, acrescentar ou retirar os vocábulos de freqüência dos atos fez-se a opção por mantê-los, com o objetivo de forçar o participante a posicionar-se diante do conceito avaliado;

- Para a segunda escala surgiram duas sugestões: a primeira que se oferecesse a possibilidade do participante escrever a sua própria opção sobre como agiria diante de cada situação proposta. A segunda sugestão foi que se oferecesse ao participante, apenas uma opção para apontar a atitude que ele tomaria, uma vez que, depois na análise dos resultados, seria necessário averiguar a nota que o sujeito atribuiu para cada opção e compará-la com a opção que ele escolheu. A segunda sugestão foi acatada, pois realmente se levou em consideração o número considerável de dados a serem tratados posteriormente.

Realizadas as alterações apontadas acima, obteve-se uma segunda versão do instrumento que foi testado num grupo de mães da cidade de Belo Horizonte. Foi lhes sugerido que além de responder a escala, apontassem os itens que não haviam entendido, fizessem sugestões e outras propostas que julgassem necessárias. Poucas sugestões foram apontadas mas eram coerentes com os apontamentos dos juízes. Alguns itens foram novamente revisados e realizaram-se as devidas correções. O objetivo dessa revisão foi a análise semântica, ou seja a verificação da adequação e compreensão dos itens.

A partir da análise semântica, através da colaboração das mães de Belo Horizonte, e dos apontamentos dos juízes, uma terceira versão do instrumento contendo 39 itens foi 
encaminhada para a análise quantitativa dos juízes, buscando as evidências de validade de conteúdo das escalas. Desde esse momento foi oferecida a prioridade para a primeira escala, sendo que apenas essa parte do instrumento passou por esse segundo processo junto aos juízes, de análise quantitativa dos itens.

\section{b- Análise teórica dos itens}

A busca da validação teórica foi realizada por cinco juízes, doutores em psicologia moral. A tarefa que lhes foi solicitada, disse respeito à análise da pertinência ou não dos itens para cada construto. Porém, conforme a fundamentação teórica dessa pesquisa, os itens que compõem as escalas em discussão não são excludentes, pelo contrário são complementares. O respeito mútuo é o sentimento moral que alicerça as relações de cooperação que conduzem a autonomia, sendo essa, a condição do sujeito que obedece a princípios de justiça comumente acordados pela troca de pontos de vista. Logo, aconteceu dos juízes apontarem determinados itens como pertencentes a dois construtos ao mesmo tempo, o que, confirmou para o presente estudo essa percepção de que os itens se completam entre si e não se excluem.

De acordo com tais apontamentos optou-se pela manutenção dos itens em seus respectivos construtos e somente dois itens (os que se mantiveram do construto da reciprocidade), foram recolocados em outros construtos reciprocamente:

12- Os pais devem usar ofensas quando necessário para educar os filhos, acrescentado no construto respeito.

13- $O$ dever dos filhos de respeitar os pais implica que os pais respeitem os filhos também, acrescentado no construto justiça.

Ainda eliminaram-se três itens, por terem a redação dúbia e se assemelharem a outros itens conforme apontou a análise quantitativa dos juízes. Foram eles:

20 - Os pais sempre devem exigir que os seus filhos cumpram as regras, e manteve-se o 27 - Deve-se obedecer aos pais mesmo quando as suas regras forem inadequadas.

44 - Os pais sempre devem exigir de seus filhos uma atitude de responsabilidade diante dos seus erros, e optou-se por manter o item de número 42 - Um pai deve ajudar os seus filhos a arcar com as conseqüencias de seus atos.

$24-E$ fundamental que os pais também obedeçam as regras dadas aos seus filhos, e manteve-se o item 13 - O dever dos filhos de respeitar os pais implica que os pais respeitem os filhos também. 
Assim terminada a validação teórica do instrumento, a pesquisadora elaborou o crivo do instrumento, bem como as instruções para o preenchimento. Essa versão do instrumento, com o crivo pode ser observada no anexo (B).

Com essa versão do instrumento, deu-se o prosseguimento a um estudo piloto, do qual participaram 12 pais e 12 mães de filhos de 12 a 20 anos. A pesquisa foi realizada em uma escola estadual de uma cidade do interior do Estado de São Paulo. A tabela que apresenta a descrição da caracterização dos participantes do estudo piloto, quanto a sua idade, formação escolar, profissão, estado civil, condição econômica, e número de filhos, encontra-se em anexo (C).

Os resultados do piloto revelaram algumas questões importantes para a sequiência do trabalho de validação:

Com relação à Escala de Juízo, os pais revelaram, por exemplo, a sua opção pelas sansões expiatórias, bem como em algumas questões nas quais fizeram a sua opção pela obediência fundamentada no respeito unilateral, afirmando utilizar, por exemplo, a estratégia da retirada do amor, ao concordarem que os filhos que amam os pais devem lhes obedecer, e, que os filhos devem saber que quando são desobedientes entristecem seus pais.

A dificuldade de educar para autonomia também se evidenciou quando concordaram que os pais deveriam dar soluções aos problemas dos filhos ou quando admitiram a dificuldade de permitir aos filhos que buscassem soluções para os seus conflitos. Outra idéia difícil aos pais foi em relação à análise da questão na qual deveriam admitir que é adequado aos pais justificar as suas ordens aos filhos. Essa pequena análise levou a acreditar que o instrumento cumpriu com o seu objetivo de investigar o que os pais pensavam sobre obediência, respeito, justiça e autonomia.

Alguns itens da escala polarizaram ou seja, a grande maioria (mais de 60\%) dos participantes respondeu da mesma forma a eles. Novamente, os itens 1, 3, 4, 6, 16, 18, 20, 21, $23,25,26,28,32,33,36$, foram analisados quanto a sua compreensão e adequação e alguns deles voltaram a sua forma de juízo da realidade, uma vez que, a escala de avaliação da ação não terá continuidade no processo, conforme os resultados abaixo descritos.

Ao analisar as respostas dos participantes, com relação às situações concretas, ou seja, com relação à escala de intervenção, a impressão que se teve foi de que os pais a responderam de modo politicamente correto.

$\mathrm{Na}$ primeira situação se evidenciou essa postura dos pais, principalmente quando, a maioria deles escolheu a alternativa que propunha o diálogo entre pais e filhos, enquanto 
houve apenas oito participantes que apontaram para uma intervenção mais relacionada ao respeito unilateral, pautado numa atitude do pai que "eduque" o filho.

A segunda situação manteve essa característica de optar pelo politicamente correto, mas revelou a idéia da atitude paterna de levar o filho desobediente a obedecer, através da punição. Outra idéia que apareceu foi a de que dois filhos deveriam sempre ser tratados com igualdade, ainda que depois afirmassem concordar com a idéia de dialogar com o filho desobediente.

A mesma sensação foi observada na terceira situação. Embora as respostas sobre as preferências se mostrassem bastante divididas, a opção que teve o maior número de adesões, apontou para um pai paciente que oferecia ajuda e ouvia ao filho.

Acredita-se que a quarta situação seja o exemplo mais adequado para demonstrar que, nas situações anteriores, os participantes fizeram a opção pelo politicamente correto. A opção pela coação e pela sansão expiatória, ilustrando a justiça retributiva, se explicitou nas respostas dos pais ainda que continuassem concordando com as respostas mais adequadas.

Observou-se que a escala de intervenções não ofereceu condição real para a mensuração das intervenções concretas dos pais. Suspeita-se que eles não tenham respondido conforme costumam agir junto aos filhos, mas, por terem opções mais adequadas, escolheram-nas, apresentando mais uma vez os seus julgamentos, o seu ideal de pais e não a sua ação sobre a realidade, conforme o objetivo a que se propunha o instrumento. Portanto, a partir desses resultados colhidos com o piloto, a presente pesquisa fez a opção de dar continuidade apenas ao estudo da escala de juízos, ou seja, a primeira escala.

Outra questão observada a partir dos resultados do estudo piloto foi a necessidade de rever - devido a grande polarização de alguns itens - a questão das graduações para a avaliação dos itens. Os participantes do estudo piloto questionaram a ausência de um ponto neutro na avaliação da escala, e além desse fato, observou-se que, uma escala com sete graduações, conforme se pode observar no quadro 5 abaixo, poderia favorecer e facilitar aspectos importantes para a medida pretendida por essa investigação:

Quadro 5- Graduações de avaliação do instrumento

\begin{tabular}{|c|c|c|c|c|c|c|}
\hline 1 & 2 & 3 & 4 & 5 & 6 & 7 \\
\hline $\begin{array}{c}\text { Discordo } \\
\text { totalmente }\end{array}$ & $\begin{array}{c}\text { Discordo } \\
\text { Bastante }\end{array}$ & Discordo & $\begin{array}{c}\text { Não } \\
\text { sei }\end{array}$ & Concordo & $\begin{array}{c}\text { Concordo } \\
\text { bastante }\end{array}$ & $\begin{array}{c}\text { Concordo } \\
\text { Plenamente }\end{array}$ \\
\hline \multicolumn{3}{|c|}{ Discordo } & \multicolumn{5}{c|}{ Concordo } \\
\hline
\end{tabular}


- $\quad$ a investigação do processo de participação dos pais na construção da autonomia do adolescente, poderia ser analisada a partir do conjunto do instrumento, cujo modelo permitiu a avaliação desse processo;

- na escala ordinal de sete pontos, conforme demonstrada pelo quadro 5, o processo também pôde ser inferido pelo posicionamento da escolha da graduação, portanto, o participante escolhia inicialmente se concordava ou não com a afirmativa e depois mensurava o quanto.

Dessa maneira a medida privilegiaria a investigação do processo inerente as relações entre pais e adolescentes enquanto participantes influentes na construção da autonomia moral dos seus filhos.

A escala que se apresenta a seguir é fruto então desse trabalho de Validade de Conteúdo descrito nas linhas anteriores, e se trata na verdade do resultado da análise e modificação de itens de várias outras versões, até que se pudesse finalmente alcançar esse modelo que aqui se apresenta, modelo esse que foi aplicado nos 860 participantess para se dar o prosseguimento a análise estatística e, portanto, Validade de Construto. Segue o Quadro 6 com a versão do instrumento utilizada para aplicação na amostra de 860 participantes ${ }^{26}$.

\section{Quadro 6 - Escala de concepções educativas}

Avalie as frases abaixo, atribuindo uma nota de 1 a 7 . Conforme o quadro que se segue:

\begin{tabular}{|c|c|c|c|c|c|c|}
\hline 1 & 2 & 3 & 4 & 5 & 6 & 7 \\
\hline $\begin{array}{c}\text { Discordo } \\
\text { totalmente }\end{array}$ & $\begin{array}{c}\text { Discordo } \\
\text { Bastante }\end{array}$ & Discordo & $\begin{array}{c}\text { Não } \\
\text { Sei }\end{array}$ & Concordo & $\begin{array}{c}\text { Concordo } \\
\text { bastante }\end{array}$ & $\begin{array}{c}\text { Concordo } \\
\text { Plenamente }\end{array}$ \\
\hline \multicolumn{3}{|c|}{ Discordo } & & \multicolumn{3}{c|}{ Concordo } \\
\hline
\end{tabular}

\begin{tabular}{|l|l|}
\hline Frases & Notas \\
\hline 1- Um pai sempre mostra interesse pelas coisas que o filho faz. & \\
\hline 2- Um pai nunca deve mexer nas coisas do filho sem pedir permissão. & \\
\hline 3- Os pais devem sempre considerar as explicações dos filhos. & \\
\hline 4- É fundamental que a ordem dada pelos pais, seja acompanhada de uma explicação. & \\
\hline $\begin{array}{l}\text { 5- Quando o filho faz alguma coisa errada, o pai deve proibi-lo de fazer algo que ele } \\
\text { goste. }\end{array}$ & \\
\hline \begin{tabular}{l} 
6- É fundamental que os pais conversem com seus filhos. \\
\hline
\end{tabular} & \\
\hline
\end{tabular}

\footnotetext{
${ }^{26}$ Essa versão do instrumento foi apresentada no sexto capítulo, quando na descrição da situação experimental, apresenta-se o instrumento da pesquisa. Entretanto, ali o quadro do instrumento apresenta também o crivo da autora. Ainda no capítulo 4 desse texto, também se pode conferir essa mesma versão do instrumento, apresentado com os itens reunidos em seus respectivos construtos, para a exposição e fundamentação teórica da sua elaboração.
} 


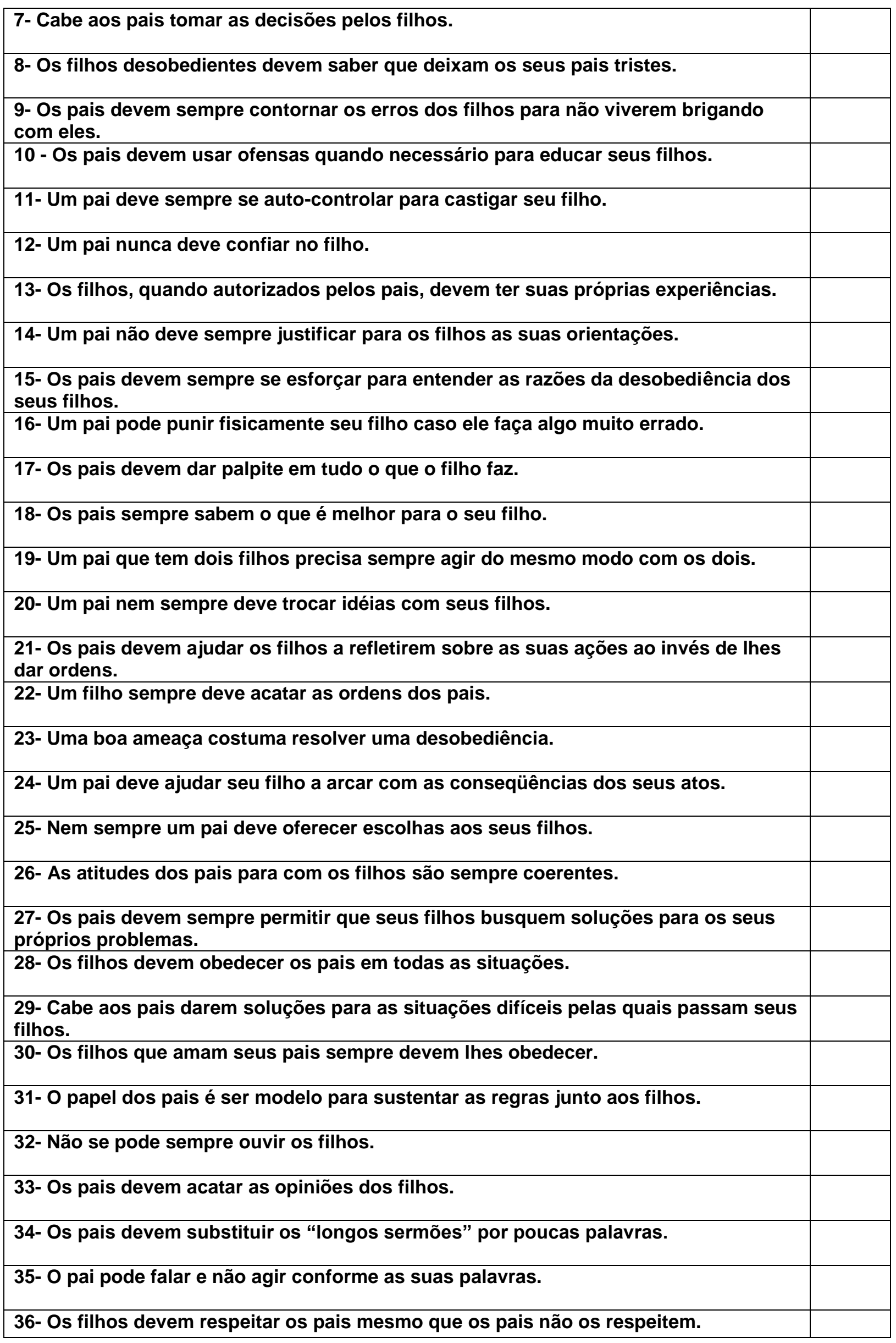




\section{2 - Validade de Construto}

Todo o desenvolvimento dessa pesquisa se constituiu no processo de elaborar itens que representassem os construtos e ou fatores que promovem a construção da autonomia moral, segundo Jean Piaget. O modelo de instrumento elaborado continha quatro construtos: respeito, obediência, justiça e autonomia, e 36 itens representativos desses fatores ${ }^{27}$, conforme apresenta o quadro 7 :

Quadro 7: Modelo do instrumento: construtos e respectivos itens

\begin{tabular}{|c|}
\hline RESPEITO \\
\hline 1- Um pai sempre mostra interesse pelas coisas que o filho faz. \\
\hline 2- Um pai nunca deve mexer nas coisas do filho sem pedir permissão. \\
\hline 6- $E$ fundamental que os pais conversem com seus filhos. \\
\hline 10 - Os pais devem usar ofensas quando necessário para educar seus filhos. \\
\hline 12- Um pai nunca deve confiar no filho. \\
\hline 14- Um pai não deve sempre justificar para os filhos as suas orientações. \\
\hline 17- Os pais devem dar palpite em tudo o que o filho faz. \\
\hline 20- Um pai nem sempre deve trocar idéias com seus filhos. \\
\hline 22- Um filho sempre deve acatar as ordens dos pais. \\
\hline 26- As atitudes dos pais para com os filhos são sempre coerentes. \\
\hline OBEDIÊNCIA \\
\hline $\begin{array}{l}\text { 4- É fundamental que a ordem dada pelos pais, seja acompanhada de uma } \\
\text { explicação. }\end{array}$ \\
\hline 8- Os filhos desobedientes devem saber que deixam os seus pais tristes. \\
\hline $\begin{array}{l}\text { 15- Os pais devem sempre se esforçar para entender as razões da } \\
\text { desobediência dos seus filhos. }\end{array}$ \\
\hline 18- Os pais sempre sabem o que é \\
\hline
\end{tabular}

${ }^{27}$ Trata-se do mesmo instrumento apresentado pelo quadro 6, todavia, nesse quadro os itens estão classificados junto aos seus respectivos construtos. 
23- Uma boa ameaça costuma resolver uma desobediência.

28- Os filhos devem obedecer os pais em todas as situações.

30- Os filhos que amam seus pais sempre devem Ihes obedecer.

31- O papel dos pais é ser modelo para sustentar as regras junto aos filhos.

\section{AUTONOMIA}

3- Os pais devem sempre considerar as explicações dos filhos.

7- Cabe aos pais tomar as decisões pelos filhos.

13- Os filhos, quando autorizados pelos pais, devem ter suas próprias experiências.

21- Os pais devem ajudar os filhos a refletirem sobre as suas ações ao invés de lhes dar ordens.

25- Nem sempre um pai deve oferecer escolhas aos seus filhos.

27- Os pais devem sempre permitir que seus filhos busquem soluções para os seus próprios problemas.

29- Cabe aos pais darem soluções para as situações difíceis pelas quais passam seus filhos.

32- Não se pode sempre ouvir os filhos.

33- Os pais devem acatar as opiniões dos filhos.

34- Os pais devem substituir os "longos sermões" por poucas palavras.

\section{JUSTIÇA}

5- Quando o filho faz alguma coisa errada, o pai deve proibi-lo de fazer algo que ele goste.

9- Os pais devem sempre contornar os erros dos filhos para não viverem brigando com eles.

11- Um pai deve sempre se auto-controlar para castigar seu filho.

16- Um pai pode punir fisicamente seu filho caso ele faça algo muito errado.

19- Um pai que tem dois filhos precisa sempre agir do mesmo modo com os dois.

24- Um pai deve ajudar seu filho a arcar com as conseqüências dos seus atos.

35- O pai pode falar e não agir conforme as suas palavras.

36- Os filhos devem respeitar os pais mesmo que os pais não os respeitem. 
Realizar a validade de construto, significa testar se o modelo teórico acima elaborado está ajustado, ou seja, se os itens representam adequadamente os construtos, tornando-os, portanto, pesquisáveis. Nas palavras de Pasquali (2003, p.164):

A validade de construto ou de conceito é considerada a forma mais fundamental de validade dos instrumentos psicológicos e com razão, dado que ela constitui a maneira direta de verificar a hipótese da legitimidade da representação comportamental dos traços latentes.

Assim a validação de construto, significa exatamente, utilizar-se da estatística como ferramenta para a testagem da hipótese psicológica do modelo. Esta validação foi feita aplicando-se a Análise Fatorial Confirmatória (Confirmatory Factor Analysis - CFA).

Conforme MacCallun e Austin (2000, p.8), a Análise Fatorial Confirmatória (CFA), é um caso especial do SEM - Structural Equation Modeling (Modelo de Equações Estruturais). Segundo esses autores, o SEM é uma ferramenta poderosa que tem sido utilizada, pelos mais diversos modelos de pesquisa em psicologia, sendo os dados que apresentam, resultados da revisão da aplicabilidade desse modelo de estatística nos últimos anos. Com relação à Análise Fatorial Confirmatória, os autores afirmam que tem sido amplamente utilizada para validação de construtos de modelos e refinamento de escalas, dentre outros tipos de aplicabilidade.

Esse foi exatamente o caso dessa pesquisa, que portanto utilizou-se da CFA para esse fim, ou seja, testar a hipótese de ajuste dos dados empíricos ao seu modelo teórico. A estrutura de relação dos itens para com os fatores foi imposta pelo modelo e foi confirmada pela análise. Ainda que se tenha admitido que os fatores ou construtos no caso dessa pesquisa são congruentes e não excludentes, cada variável ou item "deu carga" (relacionou-se) a somente um fator ou construto.

Portanto, a validade de construto de um instrumento de pesquisa é determinada pela grandeza das cargas fatoriais (que são as correlações dos itens no fator ou construto). Segundo Pasquali (2003, p. 174) as cargas fatoriais medem a correlação ou covariância dos itens nos construtos, apontando dessa forma o percentual que eles representam sobre os seus fatores, ou seja, o quanto esses indicadores ou itens são uma boa representação do construto.

Quanto à confiabilidade do construto, denominada de unidimensionalidade do construto, diz respeito à verificação de que os itens representam de fato um único construto. (Hair Jr. et al., 1998, p. 611).

A constatação da unidimensionalidade é realizada, observando-se cada valor da matriz de resíduos normalizados do construto. O valor de resíduo alto indica que aquele item não se 
ajusta ao modelo, e a manutenção desse item providencia um efeito sobre o ajuste geral do modelo tornando-o baixo.

O quadro $8^{28}$ apresenta as medidas de ajustamento do modelo. Essas medidas são observadas pelo pesquisador para realizar as modificações necessárias para que o modelo seja considerado ajustado:

\section{Quadro 8 - Medidas de ajustamento do modelo}

Qui-quadrado ponderado ( $\chi^{2} /$ graus de liberdade): É um índice de ajuste muito sensível ao tamanho amostral. Por essa razão, outros índices devem ser considerados na análise. O critério que o presente estudo adotou, no caso dessa medida, foi aceitar valores abaixo de cinco $(5,0)$, sendo que o ajuste "ideal" teria uma razão unitária.

Goodness-of-fit (GFI): Foi considerado aceito valor igual ou superior a 0,9. Trata-se de uma medida que compara os resíduos das matrizes de dados observada e estimada, produzindo um indicador que varia de zero (ajuste pobre) a um (ajuste perfeito).;

Adjusted Goodness-of-Fit Index (AGFI): É uma extensão do índice GFI, ajustado pela razão dos graus de liberdade para o modelo proposto pelos graus de liberdade para um modelo nulo. O nível de aceite recomendado é maior ou igual a 0,9

Root Mean Square Error of Approximation (RMSEA): Medida que tenta corrigir a tendência do qui-quadrado em rejeitar um modelo especificado com base em uma amostra relativamente grande. A medida no intervalo entre 0,05 e 0,08 foi aceita.

Normed fit index (NFI): É um índice que compara o modelo proposto com o modelo nulo. Varia no intervalo de zero (ausência total de ajuste) a um (ajuste perfeito). Recomendam-se valores não inferiores a 0,9.

Tucker-Lewis Index (TLI ou Nonnormed fit Index (NNFI): Resulta em valores no intervalo de zero a um, sendo aceitável se igual ou superior a 0,9;

Comparative fit index (CFI): Medida incremental que também compara os modelos nulo e estimado. Recomenda-se a medida igual ou acima de 0,9 .

Assim a validade do modelo foi realizada através de sucessivos ajustes, sendo que as alterações no modelo foram realizadas buscando maior adequação dos construtos. As medidas acima apresentadas, segundo o Quadro 8, foram sucessivamente observadas pelo pesquisador, enquanto parâmetros de ajustamento do modelo. Assim, as tomadas de decisão, como por

\footnotetext{
${ }^{28}$ O quadro 8 foi elaborado baseado nas explicações de medidas de ajuste de BomTempo, 2005.
} 
exemplo, eliminar um item, foram realizadas em função desses índices e também pela análise qualitativa dos itens em relação ao construto e a todo o processo de elaboração do instrumento - questões que serão discutidas no próximo capítulo.

Para a realização desse tipo de testagem utilizou-se um software estatístico específico para tratamento e auxílio na análise: o sistema $\operatorname{LISREL}^{\Theta}$ 8.5. Segundo Garson $(2004$, p. 2) esse software é um dos mais tradicionais "pacotes" estatísticos, destinado à modelagem de equações estruturais, ele dispõe de todos os recursos adequados para os propósitos desejados e nos últimos anos popularizou-se nas pesquisas em ciências sociais.

Todo o processo de validação aconteceu a partir então dos sucessivos ajustes, cujo objetivo maior foi aproximar-se dos valores indicados pelo quadro 8 das medidas de ajuste perfeito do modelo. Assim que o sistema ISREL $^{\circledR} 8.5$ aplicou a análise fatorial confirmatória do instrumento, averiguou-se a necessidade de realizar medidas que proporcionassem uma melhora nos índices de ajuste do modelo.

Observando os níveis de resíduos de alguns itens, identificou-se que eles não se ajustavam ao modelo por apresentarem resíduos altos. Assim foram retirados do modelo, individualmente, itens que apresentavam tal comportamento (altos resíduos). Esse foi o caso dos itens: $2,4,10,15,18,20,22,27,29,30,36$. À medida que cada um desses itens era eliminado do modelo, as medidas de ajuste do mesmo mostravam-se mais próximas dos parâmetros sugeridos pelo quadro 8.

Outra decisão que providenciou a melhora do ajuste do modelo foi estabelecer a correlação de alguns itens, como foi o caso, do item 15 com o item 17, do item 13 com o item 34, do item 25 com 33, e do item 32 com o item 33. Essa aproximação desses itens significou dizer ao modelo que tais variáveis estavam mensurando conceitos aproximados e dependentes reciprocamente, pois havia uma correlação forte entre os construtos que estavam mensurando.

Finalmente, ainda como medida de ajustamento do modelo, dois itens tiveram seus construtos alterados. Dessa forma, o item 6 que no modelo inicial representava o construto respeito, teve um ajuste melhor quando recolocado como representante do construto autonomia. E, o item 3 ficou melhor ajustado quando representando o construto justiça, quando no modelo inicial era representante do construto autonomia.

As decisões de estabelecimento das correlações entre itens, bem como a eliminação de itens e a alteração dos construtos dos itens, ampararam-se obviamente, primeiramente nos índices que se apresentam no quadro 8. Dessa forma, com o objetivo de melhorar os valores das medidas de ajustamento, as decisões acima vão sendo tomadas, na medida em que vão providenciando melhores resultados de ajustamento. Todavia, todo esse processo foi também 
definido pela reflexão teórica sobre essas decisões, ou seja, através do processo reflexivo do pesquisador a luz da teoria, da experiência da coleta de dados e de todo o processo de validação de conteúdo do instrumento. Essas reflexões teóricas serão apresentadas no capítulo discussão dos resultados.

O quadro 9 apresenta os valores das medidas do Modelo Final do instrumento após todas essas intervenções para o seu ajustamento, apresentando os valores ajustados que se referem ao resultado da validade de construto, fruto do ajuste do instrumento de medida.

A análise foi amparada complementarmente pelo gráfico Q-Plot fornecido pelo LISREL $^{\circledR}$ e que apresenta a distribuição dos resíduos padronizados relativamente a uma linha de $45^{\circ}$ do eixo. A proximidade dos pontos a essa linha indica distribuição normal dos resíduos. Esse gráfico bem como todos os demais índices e resultados, inclusive a tabela de resíduos, do tratamento estatístico: Análise Fatorial Confirmatória (CFA), realizada pelo LISREL, encontra-se no anexo D.

Quadro 9 - Medidas do modelo ajustado

\begin{tabular}{|l|c|c|}
\hline \multicolumn{1}{|c|}{ MEDIDAS } & $\begin{array}{c}\text { VALORES } \\
\text { AJUSTADOS }\end{array}$ & $\begin{array}{c}\text { VALORES } \\
\text { REFERENCIAIS }\end{array}$ \\
\hline Qui-quadrado ponderado: & $5,2^{29}$ & Abaixo de 5,0 \\
\hline Goodness-of-fit (GFI): & 0,933 & Acima de 0,90 \\
\hline $\begin{array}{l}\text { Adjusted Goodness-of-Fit } \\
\text { Index (AGFI): }\end{array}$ & 0,919 & Acima de 0,90 \\
\hline $\begin{array}{l}\text { Root Mean Square Error of } \\
\text { Approximation (RMSEA): }\end{array}$ & 0,0702 & Entre 0,05 e 0,08 \\
\hline Normed fit index (NFI): & 1,058 & Acima de 0,90 \\
\hline $\begin{array}{l}\text { Tucker-Lewis Index (TLI ou } \\
\text { Nonnormed fit Index } \\
\text { (NNFI): }\end{array}$ & 1,058 & Acima de 0,90 \\
\hline Comparative fit index (CFI): & 1.000 & \\
\hline
\end{tabular}

O quadro 10 apresenta por sua vez, o gráfico do modelo final ajustado. Esse quadro apresenta ainda os valores das correlações dos construtos entre si, e com cada item. Ainda foi possível observar na representação gráfica, todas as decisões anotadas nas linhas anteriores, referentes às providências tomadas no modelo com o intuito de ajustá-lo do modo mais próximo possível dos valores de referência (quadro 8).

\footnotetext{
${ }^{29}$ Para esse caso, com uma amostra robusta de 860 sujeitos, é natural que o valor do qui-quadrado ponderado se apresente inflacionado, logo se deve recorrer à análise do RMSEA: medida que tenta corrigir a tendência do quiquadrado em rejeitar um modelo especificado com base em uma amostra relativamente grande.
} 
Quadro 10 - Gráfico do Modelo Final Ajustado

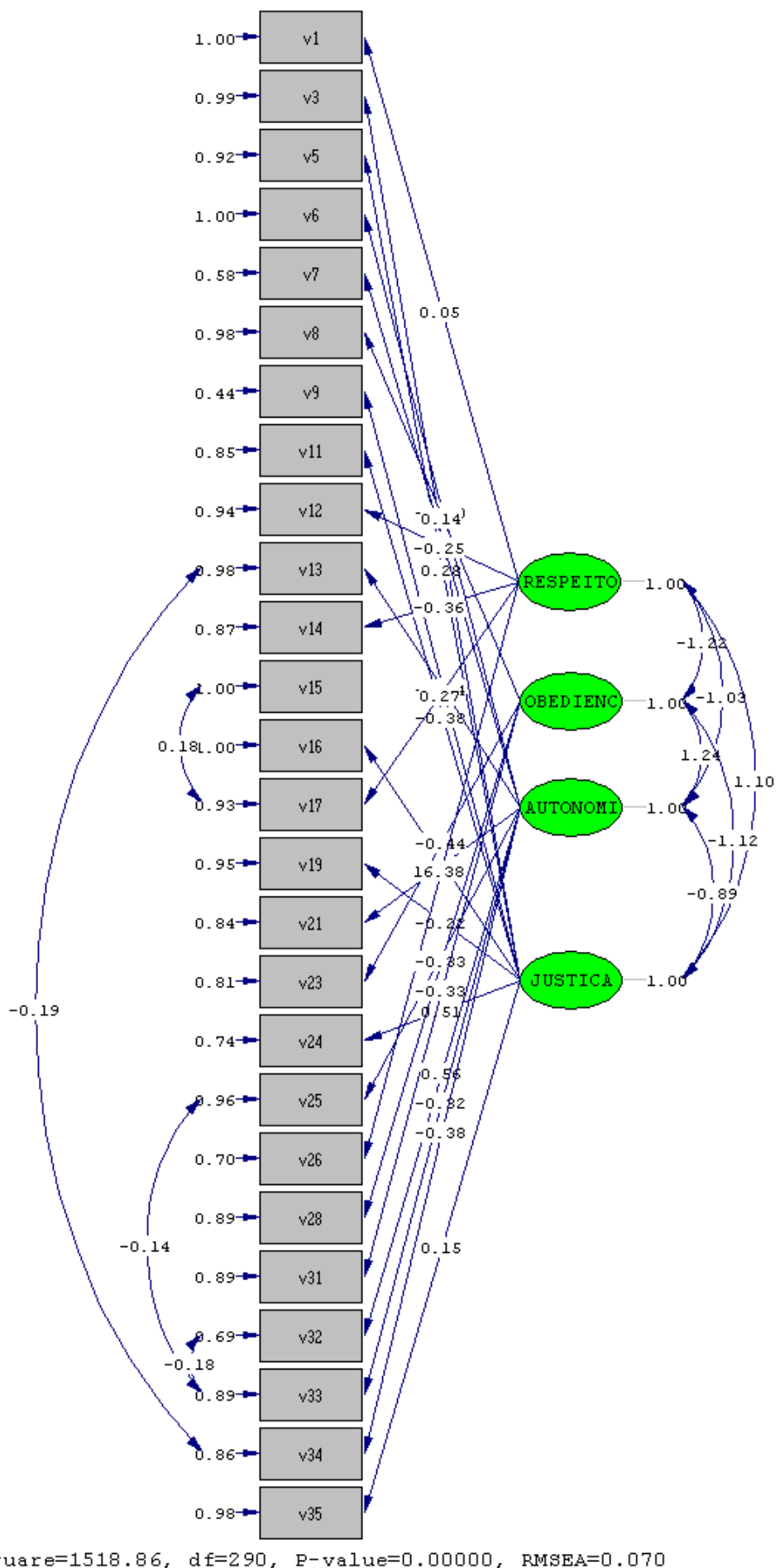

Chi-square=1518.86, $\mathrm{df}=290, \mathrm{P}-\mathrm{value}=0.00000$, RMSEA $=0.070$

Assim, o gráfico demonstra as correlações realizadas pelo pesquisador, a alteração da representação de alguns itens em relação aos seus construtos, bem como os itens que permaneceram no modelo e aqueles que foram eliminados. 
Conforme o tratamento estatístico, o modelo apresentando pelo quadro 10 é aquele que melhor se ajusta aos dados. Sendo portanto, esse o modelo final do instrumento: resposta ao objetivo principal da pesquisa.

O quadro 11 apresenta o instrumento com seus respectivos 25 itens, organizados como escala. A reflexão teórica a respeito da permanência desses 25 itens ou variáveis, bem como a eliminação dos demais itens e a organização deles nos respectivos construtos, é o tema do próximo capítulo que tem como objetivo discutir esses resultados.

O resultado das respostas dos participantes para cada item também será apresentado e discutido pelo próximo capítulo, bem como a descrição das diferenças (conforme significância estatística) encontradas em relação às variáveis dependentes: gênero, número de filhos, estado civil, profissão e escolaridade dos pais, renda familiar e idade dos participantes, tipo de escola no qual os filhos dos participantes estudam e lugares pesquisados.

Quadro 11 - Modelo Final Escala de Concepções Educativas Avalie as frases abaixo, atribuindo uma nota de 1 a 7 . Conforme o quadro que se segue:

\begin{tabular}{|c|c|c|c|c|c|c|}
\hline 1 & 2 & 3 & 4 & 5 & 6 & 7 \\
\hline $\begin{array}{c}\text { Discordo } \\
\text { totalmente }\end{array}$ & $\begin{array}{c}\text { Discordo } \\
\text { Bastante }\end{array}$ & discordo & $\begin{array}{c}\text { Não } \\
\text { sei }\end{array}$ & concordo & $\begin{array}{c}\text { Concordo } \\
\text { bastante }\end{array}$ & $\begin{array}{c}\text { Concordo } \\
\text { plenamente }\end{array}$ \\
\hline \multicolumn{3}{|c|}{ Discordo } & & \multicolumn{3}{c|}{ Concordo } \\
\hline
\end{tabular}

\begin{tabular}{|l|l|}
\hline Frases & Notas \\
\hline 1- Um pai sempre mostra interesse pelas coisas que o filho faz. & \\
\hline 2- Os pais devem sempre considerar as explicações dos filhos. & \\
\hline $\begin{array}{l}\text { 3- Quando o filho faz alguma coisa errada, o pai deve proibi-lo de fazer algo } \\
\text { que ele goste. }\end{array}$ & \\
\hline 4- É fundamental que os pais conversem com seus filhos. & \\
\hline 5- Cabe aos pais tomar as decisões pelos filhos. & \\
\hline 6- Os filhos desobedientes devem saber que deixam os seus pais tristes. & \\
\hline $\begin{array}{l}\text { 7- Os pais devem sempre contornar os erros dos filhos para não viverem } \\
\text { brigando com eles. }\end{array}$ & \\
\hline 8- Um pai deve sempre se auto-controlar para castigar seu filho. & \\
\hline 9- Um pai nunca deve confiar no filho. & \\
\hline $\begin{array}{l}\text { 10- Os filhos, quando autorizados pelos pais, devem ter suas próprias } \\
\text { experiências. }\end{array}$ & \\
\hline
\end{tabular}




\begin{tabular}{|l|l|}
\hline 11- Um pai não deve sempre justificar para os filhos as suas orientações. & \\
\hline 12- Um pai pode punir fisicamente seu filho caso ele faça algo muito errado. & \\
\hline 13- Os pais devem dar palpite em tudo o que o filho faz. & \\
\hline $\begin{array}{l}\text { 14- Um pai que tem dois filhos precisa sempre agir do mesmo modo com os } \\
\text { dois. }\end{array}$ & $\begin{array}{l}\text { 15- Os pais devem ajudar os filhos a refletirem sobre as suas ações ao invés } \\
\text { de Ihes dar ordens. }\end{array}$ \\
\hline 16- Uma boa ameaça costuma resolver uma desobediência. & \\
\hline $\begin{array}{l}\text { 17- Um pai deve ajudar seu filho a arcar com as conseqüências dos seus } \\
\text { atos. }\end{array}$ & \\
\hline 18- Nem sempre um pai deve oferecer escolhas aos seus filhos. & \\
\hline 19- As atitudes dos pais para com os filhos são sempre coerentes. & \\
\hline 20- Os filhos devem obedecer os pais em todas as situações. & \\
\hline 21- O papel dos pais é ser modelo para sustentar as regras junto aos filhos. & \\
\hline 22- Não se pode sempre ouvir os filhos. & \\
\hline 23- Os pais devem acatar as opiniões dos filhos. & \\
\hline 24- Os pais devem substituir os “longos sermões" por poucas palavras. & \\
\hline 25- O pai pode falar e não agir conforme as suas palavras. & \\
\hline
\end{tabular}




\title{
8 PAIS, ADOLESCENTES E AUTONOMIA MORAL: DISCUSSÃO DOS RESULTADOS
}

\begin{abstract}
Assim como ninguém pode ser livre por você, ninguém poderá ser justo por você, se você não se der conta de que deve sê-lo para viver bem. Para entender totalmente o que o outro pode esperar de você não há outra maneira senão amá-lo um pouco, mesmo que seja amálo porque também é humano... e nenhuma lei pode instituir esse amor pequeno, mas muito importante. Quem vive bem deve ser capaz de uma justiça simpática, ou de uma compaixão justa. (Savater, 2004, p.134).
\end{abstract}

Uma vez apresentados os resultados do processo de construção e validação do instrumento - Escala das Concepções Educativas: Pais, Adolescentes e Autonomia Moral no capítulo anterior, o objetivo desse capítulo é apresentar a discussão desses resultados, a luz da teoria que os fundamentaram, bem como refletir sobre os resultados enquanto respostas para as duas perguntas que conduziram toda a pesquisa: Quais as concepções educativas dos pais a respeito da sua participação na construção da autonomia moral dos seus filhos adolescentes?Que variáveis ou intervenções dos pais representam suas concepções a respeito de: obediência, respeito, justiça e autonomia?

A discussão dos resultados encontrados será apresentada de forma a montar um mapeamento das dificuldades e facilidades dos genitores no processo de educar para a autonomia moral, no tocante aos construtos obediência. Também será analisada qualitativamente a validação do construto, que providenciou a definição do modelo final do instrumento $^{30}$, contando com 25 itens, distribuídos segundo os respectivos fatores que eles representam, bem como os 11 itens que foram eliminados, uma vez que a análise estatística produziu uma modelo que tem muito a dizer sobre o processo de participação dos pais na construção da autonomia moral dos seus filhos adolescentes, objeto de estudo dessa pesquisa.

Dessa forma, esse capítulo será dividido em duas partes: a primeira cujo objetivo é discutir os resultados da validação do instrumento, em relação à proposta teórica do Juízo Moral de Jean Piaget. Essa parte da discussão dos resultados terá o objetivo duplo de refletir sobre o instrumento construído e validado, bem como analisar qualitativamente as respostas colhidas por ele, buscando responder as perguntas que nortearam a sua construção.

A segunda parte desse capítulo apresentará, sucintamente, um estudo das tendências segundo as variáveis dependentes: gênero, número de filhos, estado civil, profissão e

\footnotetext{
${ }^{30} \mathrm{O}$ modelo final do instrumento foi apresentado no final do sétimo capítulo e será reapresentado nesse capítulo, com os itens ou variáveis classificados em seus respectivos construtos.
} 
escolaridade dos pais, renda familiar, idade dos participantes, tipo de escola no qual os filhos dos participantes estudam e lugares pesquisados. $\mathrm{O}$ estudo das significâncias estatísticas entre tais variáveis dependentes e os construtos possibilitará o entendimento e a análise do que acontece no interior das amostras, bem como conduzirá a validades convergentes, conforme as medidas e suas comparações em relação à caracterização dos subgrupos da amostra.

\section{1- O instrumento e ao que ele responde: discussão dos resultados}

Para organizar a discussão dos resultados em relação ao instrumento (seus construtos e itens) fez-se a opção pela seguinte seqüência de reflexão: o Modelo Final do Instrumento, o estudo de cada construto, o estudo dos itens eliminados, tendo como objetivo principal responder as perguntas da pesquisa.

\subsubsection{Sobre o Modelo Final do Instrumento}

Segundo a teoria do Juízo Moral de Piaget as crianças ingressam no mundo da moralidade pelas mãos dos adultos com os quais elas convivem, especialmente, pais e mães, por quem as crianças nutrem um tipo de sentimento que reúne amor e temor, a que o autor denominou respeito. Todavia, a criança que a princípio obedece aos pais e que por isso é chamada heterônoma, deve, ao longo de seu desenvolvimento, construir a moral autônoma. Nas palavras do autor:

A autonomia é um procedimento de educação social que tende, a ensinar aos indivíduos a sair de seu egocentrismo para colaborar entre si e submeter-se às regras comuns. [...] Esta moral se caracteriza, quanto à forma, pelo aparecimento de um bem interior, independente dos deveres externos; dito de outro modo, por uma autonomia progressiva da consciência prevalescendo sobre a heteronomia dos deveres primitivos. (Piaget, 1944/ 2006, p.73).

Em outras palavras, Piaget, prevê a construção da autonomia moral, como grande conquista da adolescência, que permitirá ao jovem a elaboração de um plano de vida e a inserção no mundo social. Conforme La Taille (2007, p. 16): “A autonomia moral é definida como não necessidade de referência à figuras ou instâncias de autoridade".

Assim, embora o primeiro processo de socialização da criança se fundamente no respeito unilateral, essa espécie de sentimento que os inferiores sentem pelo superior, o que torna possível a coerção; existe outro processo de socialização possível no qual a coerção dá 
lugar às relações de cooperação e o respeito torna-se mútuo. A cooperação leva a superação da obediência à autoridade para o aparecimento de um sentimento interior independente dos deveres externos, que é chamado de obediência aos princípios de justiça, ou ainda, uma ética da solidariedade e da reciprocidade. (Piaget, 1934/1998)

Portanto, essa é para a teoria do Juízo Moral de Piaget a tendência proposta por seus estudos para o desenvolvimento moral do ser humano: a construção da autonomia moral. Uma das constatações a partir dos resultados da pesquisa é que o Modelo Final do Instrumento confirma essa expectativa teórica da proposta piagetiana de desenvolvimento psicológico moral.

O instrumento no seu modelo inicial apresentava itens que avaliavam os construtos obediência e autonomia, respeito (unilateral e mútuo), e justiça. Os itens estavam em aproximado equilíbrio contando com uma média de 8 a 9 itens para cada construto. Uma vez realizada a Validade de Construto do instrumento, observou-se um fato bastante interessante, que se pode compreender como uma comprovação matemática da expectativa teórica da proposta piagetiana para o desenvolvimento do juízo moral.

O ajustamento do modelo inicial eliminou quatro itens do construto obediência, e quatro itens do construto respeito, sendo que esses últimos, diziam respeito exatamente a variáveis que representavam relações de respeito unilateral entre pais e filhos. Dos construtos autonomia e justiça foram retirados respectivamente, apenas dois itens do primeiro e um único item do segundo.

Logo, observou-se qu para um instrumento cuja função era analisar a participação dos pais na construção da autonomia moral dos seus filhos, o resultado da validação dos construtos confirmou a tendência proposta pela teoria que o originou, ao manter o maior número de construtos representativos da autonomia, em detrimento da obediência, e também, mantendo o maior número de itens representativos da justiça, considerada por Piaget como a noção moral mais racional, resultado direto das relações de cooperação, por se fundamentar nos princípios de igualdade e equidade. (1932/1995, p. 157).

Assim, o novo modelo finalizou com quatro construtos representativos da obediência, cinco construtos representativos do construto respeito, oito construtos representativos da justiça e o mesmo número representando a autonomia. Segundo a teoria do desenvolvimento moral de Jean Piaget, para que o adolescente possa construir a autonomia moral é necessário que as relações sociais de coação ou obediência, sejam substituídas por relações de cooperação, nas quais o sentimento moral da justiça seja o equilíbrio das relações, de modo que, as pessoas escolham livremente agir em prol do bem comum. 
Estando submetido a uma coerção vinda de fora, o indivíduo não atinge a autonomia da disciplina interior que caracteriza a personalidade e, por falta de interiorização das regras, ele só sai aparentemente de seu egocentrismo, em vez de sentir-se solidário a todos. Ao contrário, a disciplina própria ao self-government é ao mesmo tempo fonte de autonomia interior e de verdadeira solidariedade. (Piaget, 1934b/1998, p. 126).

Essas evidências levam também ao entendimento de que o instrumento cumpriu a sua função no sentido de confiabilidade e validade, pois "de fato mediu o que supostamente devia medir". (Pasquali, 2003, p. 162). A pesquisa comprovou assim a tendência de que, na fase da adolescência, os pais e mães tendem a estabelecer com seus filhos relações mais fundamentadas em princípios de justiça e respeito mútuo, que conduzem à autonomia, em detrimento das relações de coação, portanto, heterônomas.

Outra observação importante a se anotar, ainda sobre a análise do modelo final do instrumento (após o seu ajustamento pela análise estatística), diz respeito ao fato de que o resultado demonstrou que o instrumento foi desencadeador de reflexões por parte dos participantes. Isso pôde ser observado pelas próprias respostas dos sujeitos (que serão apresentadas no próximo item desse capítulo), bem como, por meio de observações realizadas pela pesquisadora, durante o processo de coleta de dados:

- Não houve nenhuma pessoa convidada a participar do processo que tenha demonstrado desinteresse. Pelo contrário, houve inclusive, a questão de alguns participantes analfabetos que não quiseram abdicar da possibilidade da participação, e contaram com a ajuda de professores que se dispuseram a ler o instrumento para os mesmos e a anotar suas respostas;

- Muitos comentários foram realizados pelos participantes no seguinte sentido: "essas perguntas dizem respeito ao nosso cotidiano com nossos filhos; essas perguntas representam exatamente os dilemas que enfrentamos no dia a dia; as perguntas são bastante adequadas e nos levam a pensar sobre atitudes que tomamos muitas vezes automaticamente; que achamos importante participar desse momento de reflexão sobre a educação dos nossos filhos";

- Depois da coleta de dados a pesquisadora se dispôs a permanecer com os pais para um momento de formação, no qual, os temas abordados pelo instrumento eram discutidos sob a forma de palestra. A grande maioria dos participantes participou dessa segunda parte de formação; 
- Alguns participantes mostraram interesse, questionando a pesquisadora, de que forma, os resultados da pesquisa seriam apresentados a eles enquanto retorno da sua participação;

- Poucas dúvidas surgiram no tocante ao preenchimento do instrumento. Normalmente, em um grupo de 50 participantes, surgiam em média duas questões, e, na maioria das vezes, tais participantes queriam apenas se certificarem da sua compreensão da pergunta.

Piaget (1926/1947) - ao tratar da questão de métodos de pesquisa, abordando especificadamente o Método Clínico Crítico (conforme nomeou o método utilizado e criado por ele para as suas pesquisas a respeito do pensamento da criança) - afirma que o bom experimentador precisa ter boas hipóteses, fundamentando e dirigindo as suas perguntas, bem como, essas perguntas precisam ser formuladas de modo a desencadear reflexões nos participantes, para que se possa, realmente, conhecer o pensamento desses sujeitos em relação ao que se pergunta a eles.

Dessa maneira, pensa-se que o instrumento elaborado e validado por essa pesquisa atingiu aos seus objetivos. Embora não tenha as características do Método Clínico Piagetiano, e, devido aos objetivos já delimitados e apresentados, tenha se proposto a utilizar um modelo fechado de instrumento, como a Escala de Lickert (para investigar as concepções educativas dos pais em relação a sua participação na construção moral da autonomia dos seus filhos adolescentes), o instrumento provocou as reflexões a que se propunha, desencadeando nos participantes “crenças espontâneas”, as mais importantes para Piaget (1926/1947) no contexto de uma avaliação: quando a resposta é fruto de uma reflexão anterior e original do sujeito.

A constatação de que o instrumento contou com perguntas bem formuladas, fundamentadas em boas hipóteses se evidencia na coerência das respostas, que mensuraram ao mesmo tempo o juízo, ou seja, as representações que os pais fazem a respeito do seu papel na formação e educação de seus filhos adolescentes quanto aos construtos obediência, respeito, justiça e autonomia; e mensuraram também a ação dos pais, isto é, como estabelecem na prática essas intervenções junto aos filhos, na perspectiva de educá-los para a autonomia moral.

A análise das respostas dos participantes para cada construto deixará ainda mais consistente esse argumento. Essas constatações são, portanto fruto dessa visão do Modelo Final da Escala de Concepções Educativas, como um todo. Segue-se agora a análise dos resultados para cada construto. 


\subsubsection{Respostas aos construtos}

Depois de ter investigado pais e mães de todas as regiões do país, questionando-os a respeito de suas concepções educativas sobre sua participação na construção da autonomia moral dos seus filhos adolescentes, o objetivo foi de realizar um mapeamento a respeito dessas concepções, procurando responder as perguntas da pesquisa:

Quais as concepções educativas dos pais a respeito da sua participação na construção da autonomia moral dos seus filhos adolescentes?

Que variáveis ou intervenções dos pais representam suas concepções a respeito de: obediência, respeito, justiça e autonomia?

A idéia foi de buscar na análise das respostas a cada item, bem como na análise de cada construto, esclarecer a dificuldade de educar para a autonomia dos pais brasileiros, fazendo a leitura de suas respostas de modo a compreender suas representações a respeito da função parental e compará-las às suas intervenções.

Para isso essa análise começou pelo construto que após o ajustamento do modelo permaneceu com o menor número de itens: obediência.

A análise seguirá os seguintes passos: apresentação do construto e os itens que o compõem, apresentação dos histogramas com as freqüências percentuais de respostas para cada item e conclusões a respeito de cada construto.

\section{OBEDIÊNCIA}

\section{8- Os filhos desobedientes devem saber que deixam os seus pais tristes.}

23- Uma boa ameaça costuma resolver uma desobediência.

28- Os filhos devem obedecer os pais em todas as situações.

31- O papel dos pais é ser modelo para sustentar as regras junto aos filhos.

Conforme já indicado na análise do modelo final ajustado, no subitem anterior desse mesmo capítulo, o construto obediência, foi o que contou com o menor número de itens ou variáveis após o ajustamento do modelo. O que pode ser considerado como uma validação convergente do mesmo, uma vez que, segundo a proposta teórica do desenvolvimento moral de Jean Piaget (1932), há uma tendência na adolescência da heteronomia ou moral da obediência ser substituída pela moral autônoma. 
Entretanto, quando se observa as respostas para cada variável que permaneceu no construto, após o processo de ajustamento do mesmo, pode-se conferir um resultado que se repetirá nos demais construtos: uma nítida diferenciação entre o que pensam os pais sobre o processo educativo dos seus filhos ou ainda as representações que possuem sobre o que é adequado enquanto educação para os seus filhos, ou seja, o seu juízo a respeito da função parental, e a ação moral, isto é, as intervenções concretas que afirmam adotar com os mesmos.

Acredita-se que desse fato se possa distinguir outra evidência de validade convergente do instrumento, uma vez que, os resultados demonstraram com rigorosidade a dialética entre juízo e ação moral, com relação ao processo de educação dos adolescentes. Essa dicotomia e muitas vezes contradição como se poderá identificar ao longo da discussão dos resultados, foi bastante evidente para os quatro construtos.

Assim, o quadro 12 apresenta os histogramas $\operatorname{comentados}^{31}$ dos quatro itens que compõem o construto obediência. Os resultados permitiram observar que a intenção dos pais não é formar os seus filhos para a obediência cega. Aquela obediência que implica em submissão a figura da autoridade. Ficou evidente a diferença entre o juízo e a ação moral dos pais. Seguem os comentários a respeito de cada item, bem como a apresentação de pesquisas relacionadas à relação pais e adolescentes e o conceito de autoridade.

Quadro 12 - Histograma $^{32}$ dos itens que compõem OBEDIÊNCIA

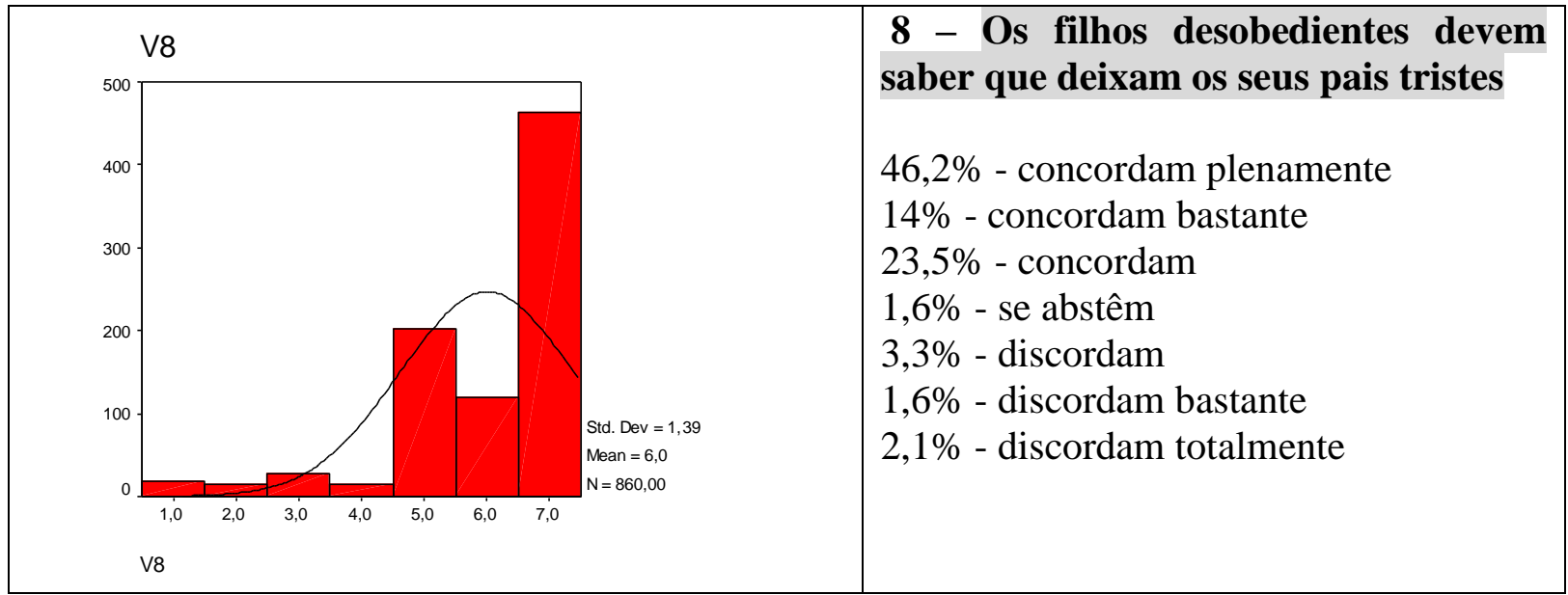

\footnotetext{
${ }^{31}$ Todos os itens que permaneceram no modelo foram representados pelo seu respectivo histograma, bem como, pela freqüência percentual respectiva a cada possibilidade de resposta ao item.

32 Os histogramas são representativos das freqüências estatísticas das respostas dos pais para cada item. Os números das coordenadas horizontais referem-se às categorias de respostas (a escala de 7 pontos), e as coordenadas verticais referem-se ao número absoluto de participantes que aderiram a cada resposta. As freqüências percentuais são apresentadas no quadro ao lado de cada histograma.
} 


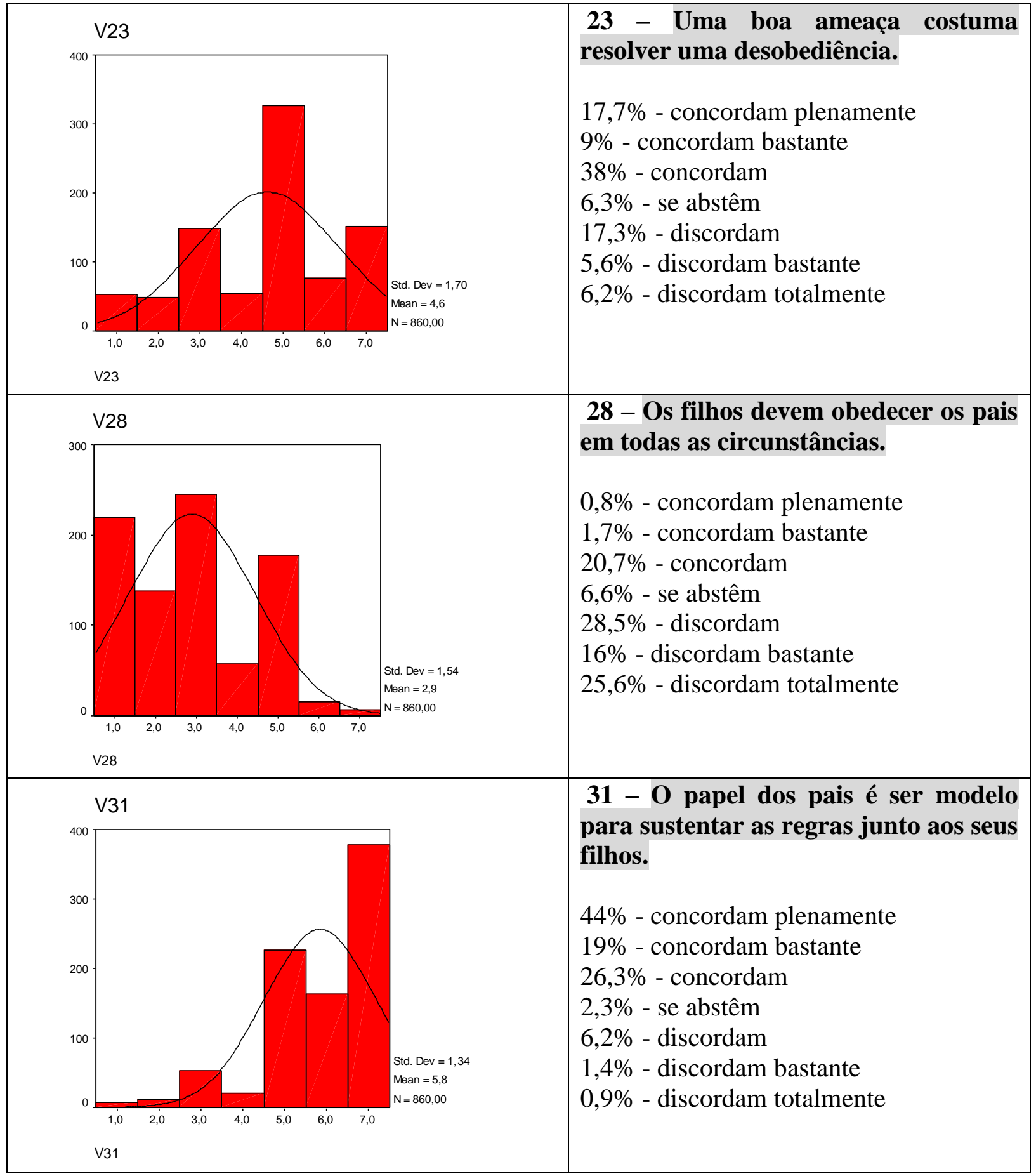

Com relação às diferenças entre o juízo e a ação moral foi possível observar de imediato pelos resultados que, nenhum pai deseja que o seu filho seja obediente. A obediência cega não é bem vinda e os pais afirmam que os filhos não devem obedecer os pais em quaisquer circunstâncias. Da mesma forma, também afirmam que é papel dos pais ser modelo para sustentar as regras junto aos seus filhos. Assim, segundo o seu julgamento, compreendem a importância de ser modelo para o filho, mas sem exigir dele completa submissão. Entretanto 
admitem usar das ameaças para resolver um problema de desobediência, além de admitirem também que os filhos desobedientes entristecem os pais.

Observou-se assim que o juízo é contraposto pela ação. Fazer ameaças não é bom modelo, bem como a questão da chantagem emocional exposta pela utilização do sentimento de tristeza como conseqüência para a desobediência. Com relação à questão das ameaças, o estudo de Caetano (2008, p. 134) também demonstrou que os pais costumam utilizar as ameaças como estratégias para conseguir a obediência. Segundo os relatos coletados, os pais afirmaram que costumavam dizer aos filhos que se não obedecessem seriam castigados, perderiam as coisas que mais gostavam, e, entre outras questões afirmavam que fazeiam pressão, davam bronca e levantavam a voz.

O estudo de Smetana, Crean e Campione-Barr (2005, p.37) a respeito das concepções de pais e adolescentes sobre a autoridade parental, chama a atenção para a necessidade de distinção entre controle de comportamento e controle psicológico, exercido pelos pais. Conforme Nucci, Hasebe e Lins-Dyer (2005, p.19) o controle psicológico se refere aos esforços dos pais para manipular as idéias dos adolescentes, invandindo o limite da intimidade e privacidade dos jovens, bem como interferindo em questões do domínio pessoal de suas vidas.

A idéia do domínio pessoal faz parte da Teoria dos Domínios Sociais de Turiel (1983). Este autor fez a distinção entre convenção social e moralidade. Para ele as regras podem pertencer a três diferentes domínios: o moral, o convencional e o pessoal, e as crianças das mais diferentes culturas conseguem distingui-los. O domínio moral diz respeito aos deveres que orientam as convivências com os outros, o domínio convencional se refere às normas arbitrárias propostas pelo contexto social e o domínio pessoal se refere às regras que têm conseqüências somente para o seu próprio autor. (Smetana 2005, p. 120).

Para Smetana e Asquith (1994, p. 1147) que investigaram o conceito de autoridade parental e autonomia pessoal, em adolescentes e pais, utilizando a Teoria do Domínio Social de Turiel (1983, 1989), adolescentes e pais concordam com a legitimidade dos pais para o domínio moral (definindo os atos que são prescritivamente errados porque afetam o direito e o bem estar dos outros) e para o domínio convencional (definido como o arbitrário e consensual acordo em relação a comportamentos definidos pela interação com o grupo social no qual se vive). Entretanto adolescentes discordam da participação dos pais nas idéias de domínio pessoal e seus pais discordam deles a respeito disso.

Dentre as idéias pertencentes ao domínio pessoal, encontram-se: a escolha dos amigos, escolha de roupas, músicas, corte de cabelo. Todavia, a autora ainda investiga, algumas 
questões que são, no caso da relação pais e adolescentes, categorizadas em outros domínios, como por exemplo, o domínio prudencial (para questões relacionadas ao hábito de fumar, consumir bebidas alcoólicas, usar drogas, sexualidade), e ainda questões de um âmbito multifacetado (ouvir música alta, não arrumar o quarto, não usar roupas limpas, etc), classificadas pelos jovens como atitudes do domínio pessoal, mas que na verdade, têm conseqüências diretas para a convivência com os pais, como por exemplo, a questão da organização do próprio quarto.

Conforme se pode observar, as diferenças nos raciocínios e julgamentos de pais e adolescentes aparecem especialmente, segundo a pesquisa de Smetana e Asquith (1994, p. 1160), no âmbito do domínio prudencial, multifacetado e pessoal, que para os adolescentes são vistos todos como questões que compõem a sua privacidade (domínio pessoal), enquanto que os pais entendem que devem interferir em todas essas facetas. Os resultados também indicam que "as idéias morais são discutidas com pouca freqüência e tais discussões são mais severas que nos outros domínios, pois as transgressões morais são consideradas mais sérias do que outras transgressões.” (Smetana e Asquith, 1994, p. 1161).

Para Nucci (1981) o domínio pessoal se refere às ações que dizem respeito aos aspectos privados da vida das pessoas, e portanto, o controle parental desse aspecto não é adequado, no sentido de que, o domínio pessoal no adolescente, emerge da necessidade de estabelecer fronteiras entre o si mesmo e o outro, e, portanto, segundo o autor, o respeito dos pais pelo domínio pessoal é extremamente importante para a construção da personalidade autônoma e da identidade individual. É por isso que o controle dos pais aos aspectos do domínio pessoal é considerado como controle psicológico.

Segundo os autores, Smetana, Crean e Campione-Barr (2005, p.37), o controle psicológico inclui ainda: "O comportamento intruso dos pais, a retirada do amor, e indução à culpa, o que inibe o desenvolvimento do adolescente interferindo no desenvolvimento saudável do self e da identidade”. (Smetana, Crean e Campione-Barr, 2005, p.37).

Ainda que esse trabalho não utilize a teoria do Domínio Social é importante apresentar aqui os resultados dessas investigações, por se tratar de estudos realizados na abordagem cognitivista de desenvolvimento moral dentro do domínio da relação pais e adolescentes, e, uma vez que esse construto trata das relações de obediência, é importante compreender o que relatam as pesquisas sobre as concepções de pais e adolescentes a respeito da autoridade parental. Ainda que os pais dessa pesquisa não façam a opção pelo juízo da obediência ao falarem da sua ação, relatam o uso da ameaça e da retirada do amor para impor aos filhos a sua autoridade parental. 
Na verdade essa pesquisa não se debruçou sobre a análise de em quais domínios de regras os pais têm maior autoridade, ou seja: o domínio convencional, pessoal, prudencial ou moral. A proposta da pesquisa foi compreender as concepções educativas sobre a obediência no sentido de "forma" e não "conteúdo" da maneira de educar. Assim interessa refletir aqui sobre "as formas" que os genitores afirmaram utilizar para alcançar a obediência dos filhos, como por exemplo, a ameaça e a retirada do amor.

A questão da retirada do amor como estratégia de controle por parte dos pais foi estudada pelo autor americano Hoffman (1970). Para ele essa forma de atitude produz a separação entre pais e filhos, pois tende a produzir ansiedade e revolta nos adolescentes, reduzindo ou impedindo a comunicação entre ambos. Por outro lado, a retirada do amor, ou chantagem emocional alimenta a imagem dos pais como pessoas que punem, que agem de forma arbitrária, que chantageiam, e por isso, alguém que deve ser evitado e não alguém de quem se possa aproximar ou alguém com quem se queira dialogar, o que posteriormente diminui a influência do pai.

Quanto à ameaça, que os pais afirmam utilizar, tem relação com as questões das sanções que serão apresentadas na análise do construto justiça e que terão extrema importância para a análise geral de como pensam os pais e mães brasileiros a respeito da educação moral dos seus filhos.

Segue a discussão sobre o construto respeito. Assim como no construto obediência, as contradições podem ser observadas em relação aos resultados que apresentam a relação entre o que os pais julgam o ideal de como devem ser as relações de respeito com os seus filhos em comparação às atitudes que eles afirmam tomar.

\begin{tabular}{|l|}
\hline RESPEITO \\
\hline 1- Um pai sempre mostra interesse pelas coisas que o filho faz. \\
\hline 12- Um pai nunca deve confiar no filho. \\
\hline 14- Um pai não deve sempre justificar para os filhos as suas orientações. \\
\hline 17- Os pais devem dar palpite em tudo o que o filho faz. \\
\hline 26- As atitudes dos pais para com os filhos são sempre coerentes. \\
\hline
\end{tabular}


A observação dos resultados obtidos para cada item ou variável, pode ser observada no quadro 13 que apresenta os histogramas comentados para os itens que representam o construto respeito.

Os dados revelaram que os pais julgam como respeito para com os seus filhos, providenciar-lhes a devida atenção. Nesse caso, $87 \%{ }^{33}$ dos participantes concordaram com a necessidade de demonstrar interesse pelas coisas que os filhos fazem. Entretanto, também se acharam no direito $(57,9 \%)$ de dar palpites em todas as coisas que os filhos fazem. Esses resultados são consistentes com aqueles apresentados no construto anterior, sobre os problemas apontados pelos adolescentes de se sentirem invadidos pelos pais nas questões entendidas por eles como do âmbito da sua privacidade (domínio pessoal). (Smetana e Asquith, 1994; Smetana, Crean e Campione-Barr, 2005; Nucci, Hasebe e Lins-Dyer, 2005).

Outros estudos com adolescentes dos Estados Unidos, da China, Japão, Colombia, citados por Milnitsky-Sapiro, Turiel e Nucci (2006) que investigaram também adolescentes do Brasil, encontraram a mesma queixa dos jovens em relação à invasão dos pais às questões do domínio pessoal.

Quadro 13 - Histograma dos itens que compõem RESPEITO

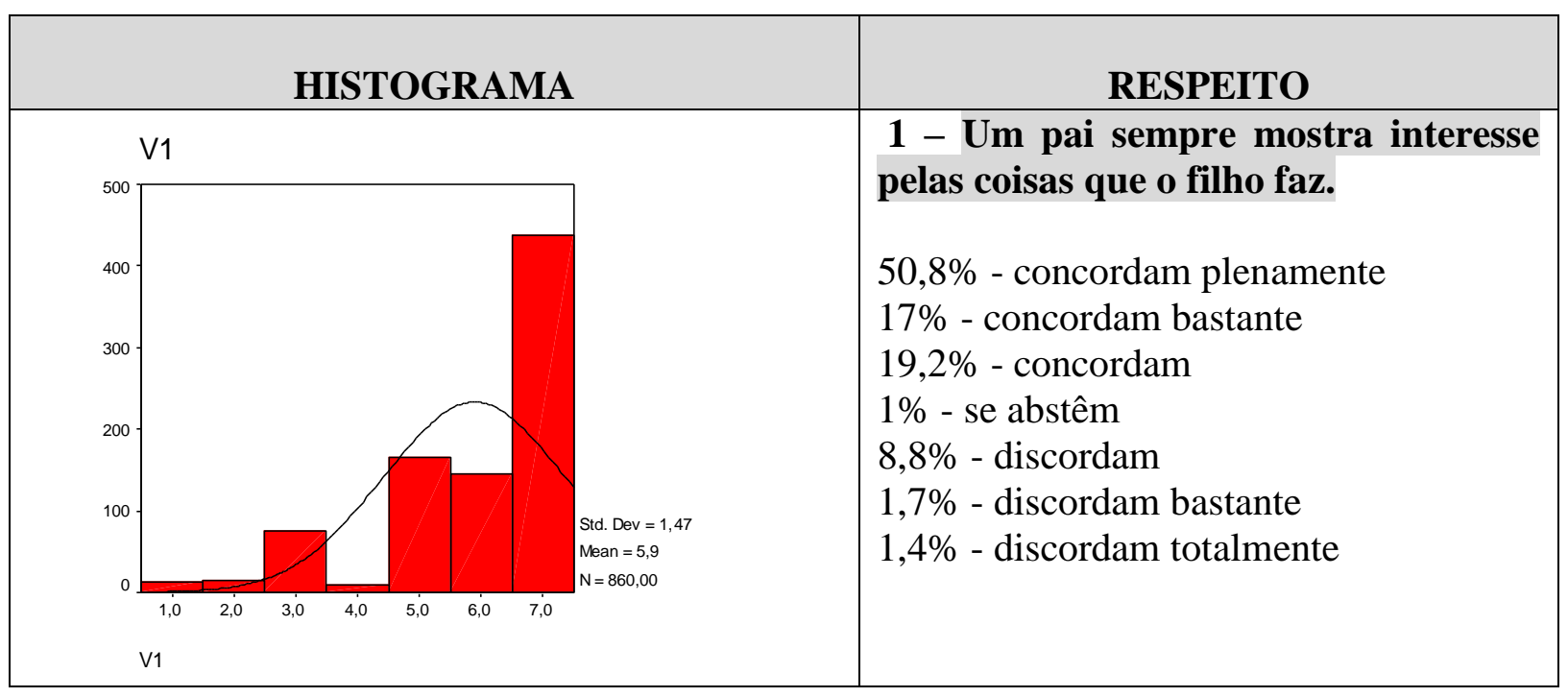

\footnotetext{
${ }^{33}$ Quando os valores percentuais são apresentados sob o título "o percentual de pais concordam”, a consideração que se faz é a soma das respostas: concordo plenamente, concordo bastante e concordo; sendo o mesmo raciocínio utilizado para quando se remete ao "percentual de participantes que discordam".
} 


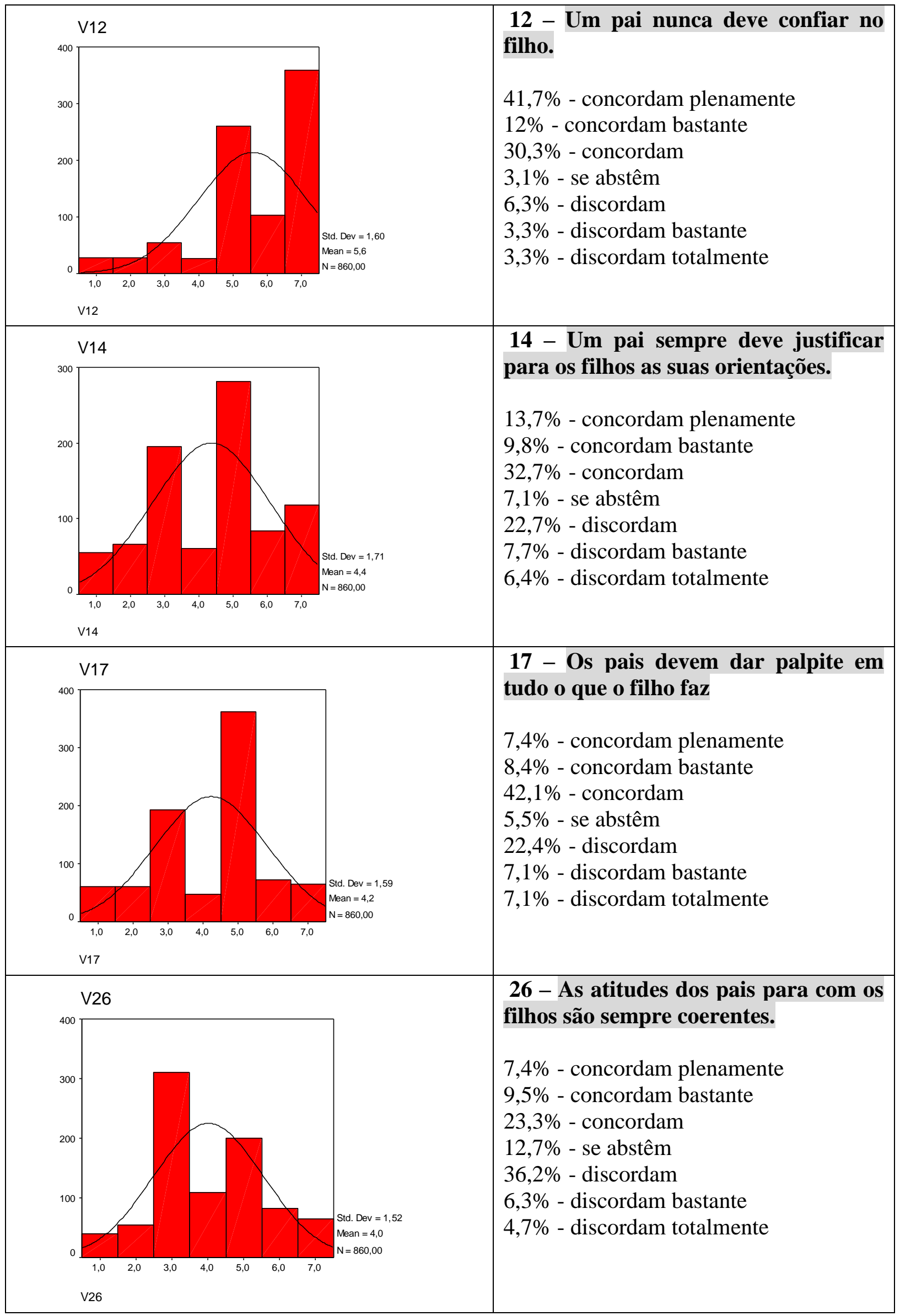


Os estudos realizados por Milnitsky-Sapiro, Turiel e Nucci (2006, p.328) a respeito das concepções de autonomia e autoridade parental no Brasil, demonstraram que a autonomia e a prerrogativa de tomadas de decisões independentemente dos pais são parte do pensamento dos adolescentes brasileiros. Conforme os dados da pesquisa, os adolescentes requerem o respeito às decisões do âmbito do domínio pessoal como encontros, amigos, opções por roupas, músicas, etc. Mas, por outro lado, requerem também a participação e o acompanhamento dos genitores nas questões que possam colocá-los em risco. "Os adolescentes brasileiros requerem autonomia e privacidade, mas também aceitam o papel da autoridade parental". (MilnitskySapiro, Turiel e Nucci, 2006, p.317).

A dificuldade para os pais parece estar exatamente na distinção entre esse limite do que significa ocupar o lugar de adulto da relação e portanto, ser cooperativo com o processo de construção da autonomia do jovem. Desse modo, admitir dar palpite em tudo o que o filho faz, implica em um desrespeito pelo limite da intimidade do adolescente, especialmente importante nessa fase. Segundo La Taille (1998, p. 140), “a construção da personalidade e a conquista da autonomia passam pelo controle seletivo do acesso de outrem ao eu, pela construção de fronteiras de intimidade".

Por outro lado, ainda atrelada às questões que se apresentaram em relação à invasão dos domínios pessoais, ou simplesmente, invasão da intimidade ou privacidade alheia, outro item exposto pelo instrumento trouxe resultados bastante sérios e que muito se relacionaram a essas questões: $84 \%$ dos pais afirmam que nunca se deve confiar nos filhos. Uma das variáveis eliminada pelo ajustamento do $\operatorname{modelo}^{34}$ (o item 2), afirmava que os pais nunca devem mexer nas coisas do filho sem pedir permissão. Da mesma forma, a grande maioria, discordou, admitindo, portanto, que invadem a privacidade dos filhos, e mais que isso, com a sua atitude descaracterizam para os filhos a importância do respeito à propriedade alheia, seja ela, um guarda-roupa, um diário, uma mochila, uma casa, uma biblioteca, enfim.

Entretanto qual o significado da afirmação: um pai nunca deve confiar no seu filho?

Em primeiro lugar, não confiar nunca no filho conforme exposto acima, também é indício de que, o pai ou mãe se acham no direito de invadir a privacidade dele, de acordo com o comportamento já admitido pela concordância com o item 17 (Os pais devem dar palpite em tudo o que o filho faz). Conforme La Taille (2006, p. 91): “O equilíbrio psicológico, depende, entre outros fatores, da capacidade de ter intimidade, logo, da capacidade de preservar áreas

\footnotetext{
${ }^{34}$ Os itens eliminados do instrumento serão comentados ainda nesse capítulo, após a discussão dos resultados dos quatro construtos.
} 
secretas, de abri-las no momento em que se deseja fazê-lo, e a quem se deseja dar o acesso". Para o autor, é ainda mais condenável e violento o ato de invasão aos limites de intimidade de alguém, quando a intenção é subjugar e humilhar.

Infelizmente, parece que existe uma tendência dos pais em agirem dessa forma, conforme as observações de Piaget (1932/1994, p. 152) sobre a forma intitulada por ele como medíocre, dos pais conduzirem a educação dos filhos:

Como não ficar impressionado com uma série de contra-sensos psicológicos: [...] o prazer de usar sua autoridade e esta espécie de sadismo que observamos tão freqüentemente mesmo entre muita gente educada, cuja máxima é que é necessário "quebrar a vontade da criança" ou "fazer sentir à criança que há uma vontade superior à dela". (Piaget, 1932/1994, p.152).

Em segundo lugar, admitir que não se deve nunca confiar no filho significa a admissão por parte dos pais de uma relação de respeito unilateral com eles e é o mesmo que afirmar que esse filho precisa ser constantemente vigiado, pois a qualquer momento pode fazer algo de errado. Piaget (1945/1998) afirma que o processo educativo precisa levar as crianças a pensarem, a fazerem suas próprias críticas, a trocarem pontos de vista, num espírito de solidariedade, fonte de valores novos. Quando não se confia nessa capacidade de raciocínio, de tomada de consciência e legitimação das regras e princípios de justiça por parte do educando, não se pode estabelecer com eles relações de cooperação e solidariedade.

Em terceiro lugar, portanto, "confiar em alguém, seja em que área da atividade humana for, sempre implica fazer consideração sobre a moralidade da pessoa, na qual se confia". (La Taille, 2006, p. 110). A questão da confiança pertence, então, à dimensão moral. As crianças precisam encontrar em seus pais a fonte e o modelo das regras. Segundo, La Taille (2006, p. 113), as crianças se sentem enganadas e injustiçadas quando perdem a confiança nos adultos, por perceberem que as regras impostas por eles, não são seguidas pelos mesmos.

No caso do adolescente, o fato de "merecer" a auto-confiança se torna central, pois no despertar de uma personalidade ética a questão da construção das representações de si são de extrema importância. Nesse processo de constituir o auto-respeito, ou as suas representações de si mesmo, as opiniões e juízos alheios contam muito. Dessa forma: "Querer ser merecedor de confiança é um traço essencial do auto-respeito: quem tem honra sente vergonha de ter desmerecido a confiança alheia ou simplesmente ter pensado em realizar ações que teriam esse efeito". (La Taille, 2006, p.141).

Finalmente, nunca confiar no filho adolescente implica em assumir uma dificuldade inerente ao processo de educar para a moralidade. Uma vez que pais e mães tenham 
trabalhado com regras junto aos seus filhos, desde a sua infância, não deveriam se tornar tão desconfiados na adolescência. Desconfiar do filho é uma forma de desrespeito. Já respeitar é exatamente o contrário de vigiar. "Respeitar é se aproximar da pessoa mesmo no conflito, na discordância, nas diferenças, nos embates, para reconhecer as mudanças necessárias e alterar os rumos das relações e até mesmo dos projetos compartilhados”. (Sayão, 2003, p. 108).

As respostas dos pais ao item 26: "as atitudes dos pais para com os filhos são sempre coerentes", também corroboram essa dificuldade expressa pela desconfiança em relação aos filhos. Ao afirmarem $(47,2 \%)$ que discordam de que as atitudes dos pais para com os filhos são sempre coerentes, demonstram contradição da ação em relação ao julgamento moral (conforme a resposta ao item 32 de obediência), uma vez que haviam confirmado a concordância com a idéia de que todo pai deve ser modelo das regras que quer ensinar aos seus filhos. Logo, esses filhos viverão a inconsistência da atitude dos pais que, tenderam a comportamentos pautados na filosofia do ditado popular: "faça o que eu falo, mas não faça o que eu faço".

A pesquisa de Perkins e Turiel (2007) examinou o julgamento de adolescentes americanos sobre mentir para desviar das diretivas dos pais ou amigos, nos domínios moral, prudencial e pessoal. Os resultados do estudo revelaram que no contexto das suas crenças sobre honestidade, os adolescentes fazem várias distinções sobre a natureza das relações e os tipos dos atos. Mas, embora considerem mais errado mentir para os pais do que para os amigos, julgam aceitáveis as decepções dos pais em relação as suas mentiras no domínio moral e pessoal. O mais interessante nesse estudo é que: "Os resultados indicam que os julgamentos sobre a decepção dos pais estão ligados com as percepções da legitimidade das diretivas parentais". (Perkins e Turiel, 2007, p. 618). Algumas mentiras aos pais foram justificadas pelos jovens como aceitáveis, pela consideração de que as diretivas dos pais eram injustas.

Obviamente, essa questão da incoerência dos pais é percebida pelos filhos e pode provocar e desencadear comportamentos inadequados, entre eles, a mentira, conforme demonstrado pelo estudo acima exposto. Todavia, é bastante importante os pais admitirem que nem sempre agem com coerência, como demonstrado pelos resultados dessa pesquisa, na qual, inclusive, $12,7 \%$ dos participantes, atribuíram nota quatro (que denota dúvida) para a assertiva, demonstrando uma tomada de consciência do respeito às regras e aos próprios filhos.

O último item que compõe o construto respeito, também revela a reflexão dos pais sobre o tema. O item 14 trata da necessidade de justificar para os filhos as orientações dos pais. 
Ainda que $22,7 \%$ discordem, encontra-se o percentual de $56,2 \%$ dos pais afirmando a necessidade de explicar o porquê das regras ou limites trabalhados com os filhos. Esse posicionamento, indica respeito para com os filhos e reconhecimento da sua capacidade de raciocínio e reflexão. "Em resumo, a associação entre limites e justificativas racionais prepara para a conquista da autonomia, que pressupõe justamente uma apreensão racional dos valores e das regras". (La Taille, 1998, p. 100). Bastante respeitoso e justo agir assim, para quem deseja formar seres humanos.

O que pensam então os pais brasileiros sobre as relações de justiça que estabelecem com seus filhos?

\begin{tabular}{|l|}
\hline \multicolumn{1}{|c|}{ JUSTIÇA } \\
\hline 3- Os pais devem sempre considerar as explicações dos filhos. \\
\hline 5- Quando o filho faz alguma coisa errada, o pai deve proibi-lo de fazer algo que ele goste. \\
\hline 9- Os pais devem sempre contornar os erros dos filhos para não viverem brigando com eles. \\
\hline 11- Um pai deve sempre se auto-controlar para castigar seu filho. \\
\hline 16- Um pai pode punir fisicamente seu filho caso ele faça algo muito errado. \\
\hline 19- Um pai que tem dois filhos precisa sempre agir do mesmo modo com os dois. \\
\hline 24- Um pai deve ajudar seu filho a arcar com as conseqüências dos seus atos. \\
\hline 35- O pai pode falar e não agir conforme as suas palavras. \\
\hline
\end{tabular}

Os resultados encontrados nas respostas aos itens desse construto apresentam ainda mais que aos demais, o distanciamento entre juízo moral e ação moral. Especialmente porque o fator justiça está estritamente ligado à idéia de sansão, os resultados apresentam a grande dificuldade dos pais: a questão do processo da legitimação e interiorização das regras e dos limites.

As variáveis 5, 9, 11, 16, 19 e 24, dizem respeito à questão da sanção, absolutamente ligada ao sentimento de justiça, uma vez que, para Piaget (1932) a justiça se inspira em princípios de igualdade e equidade. Portanto, é uma questão de justiça a decisão de como punir o culpado, definindo a relação entre os atos e suas consequiências; dessa forma, o que os pais fazem para punir os seus filhos quando eles não cumprem as regras, responde a questões 
do construto justiça e são discutidas pelos itens apontados no início desse parágrafo. Segundo Menin (2005, p. 20):

Discutindo os fatores da evolução da justiça, Piaget, descarta o inatismo e a influência direta dos ensinamentos dos adultos. Novamente, o autor vê a influência adulta mais como fonte de atraso do que fonte de desenvolvimento, pois afirma que a autoridade não poderia ser fonte de justiça, já que esta supõe a autonomia, relações entre iguais que assim se tratam.

Serão apresentadas a seguir as opções apontadas pelos pais brasileiros no tocante, aos seus julgamentos sobre justiça, e sobre os tipos de atitudes em relação às regras ou limites.

Quadro 14 - Histograma dos itens que compõem JUSTIÇA

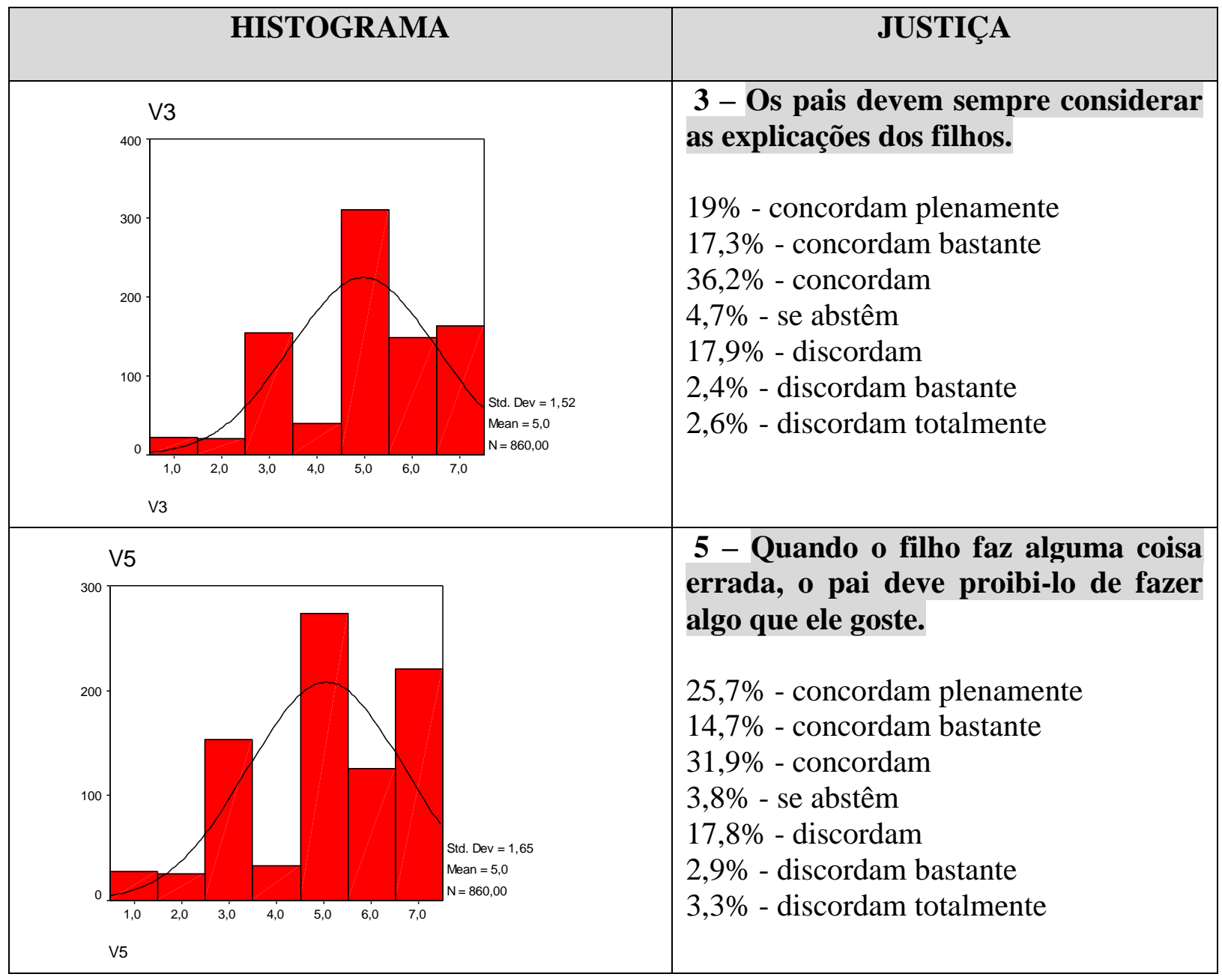




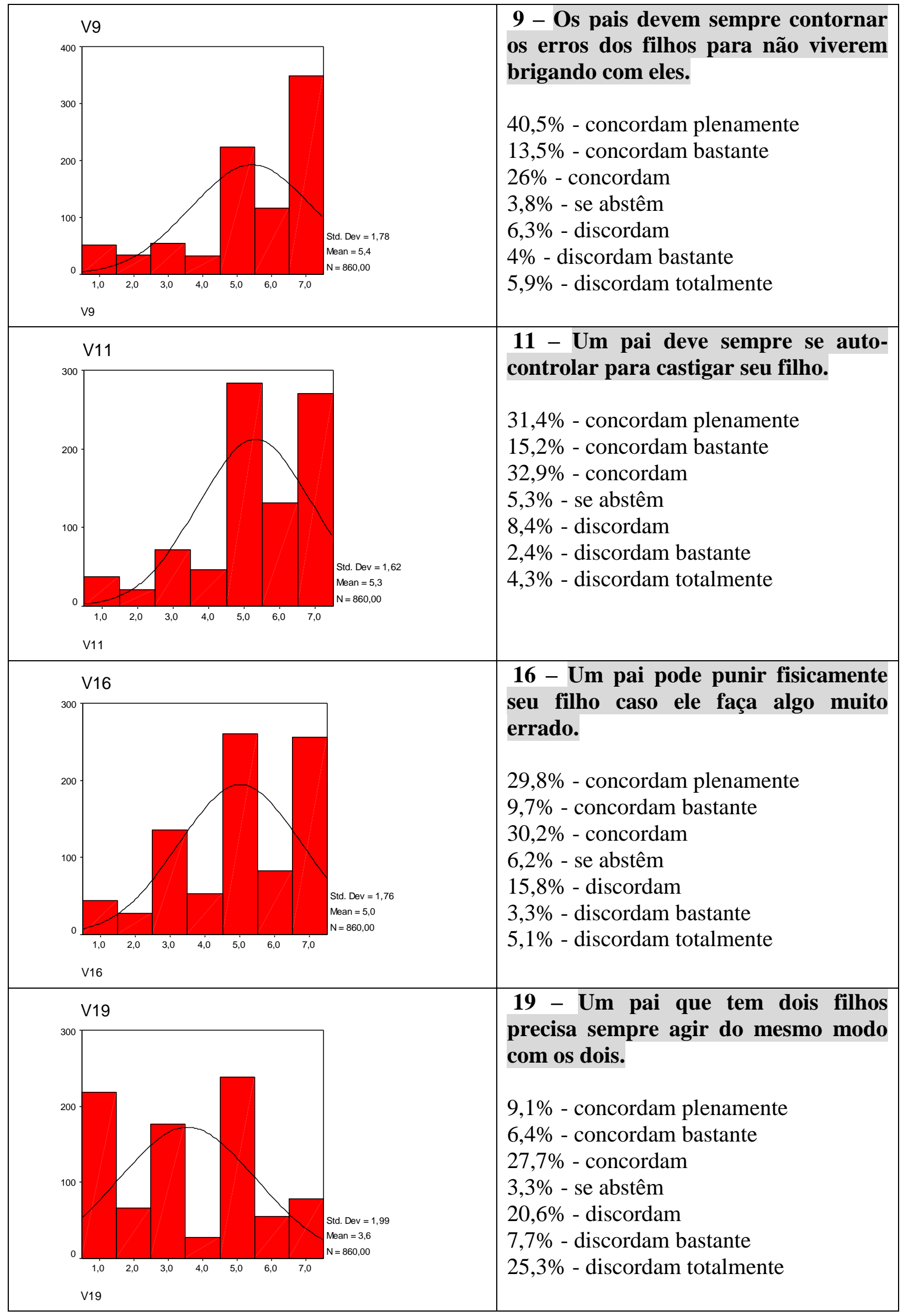




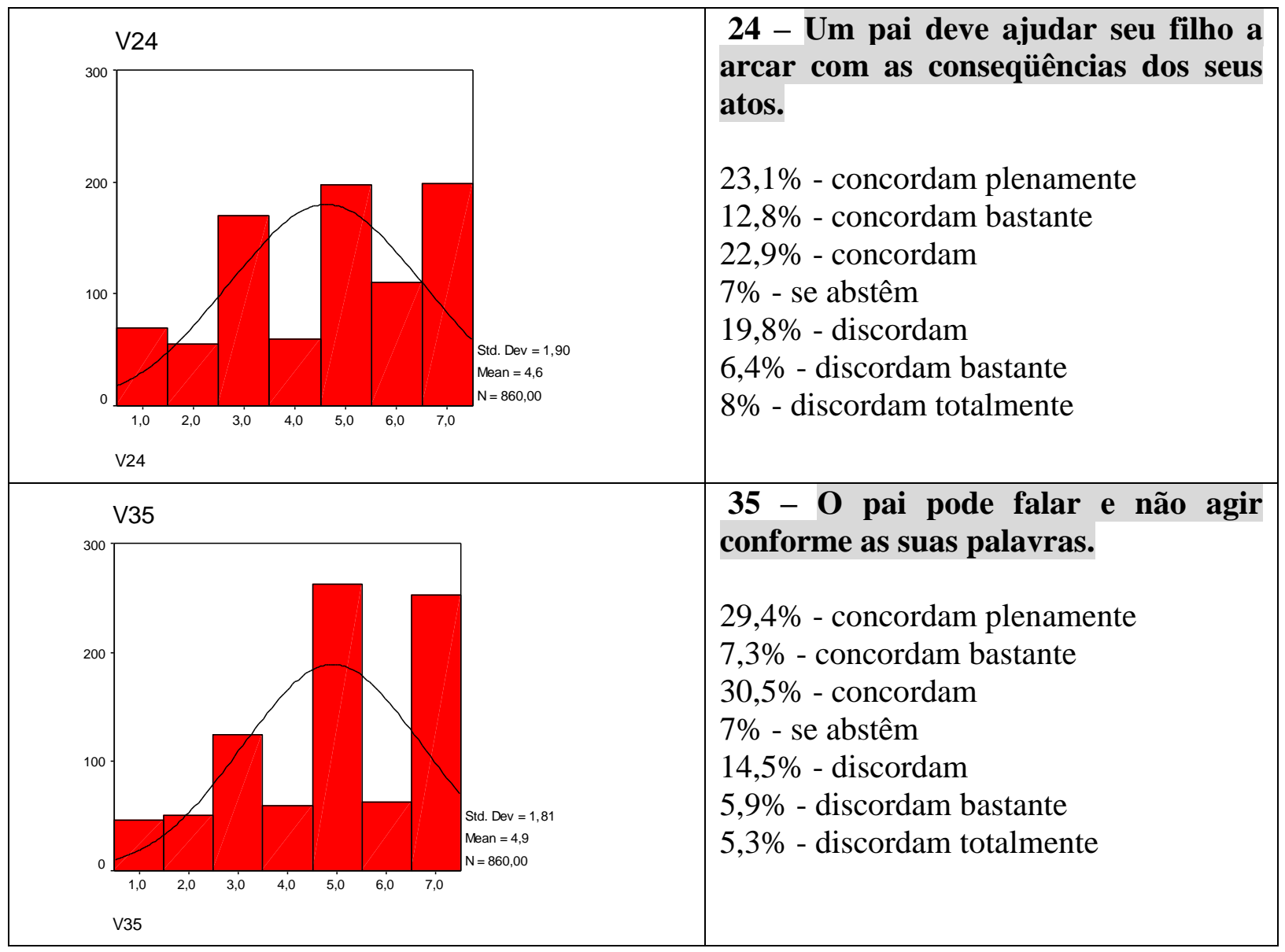

Interessante que os 72,5\% de participantes concordaram com a necessidade de sempre considerar as explicações dos filhos (item 3) o que denota um juízo moral justo, pautado nas relações de respeito mútuo e cooperação. Segundo a pesquisa de Smetana (1999, p.316) a respeito do papel dos pais no desenvolvimento moral, de acordo com a Teoria do domínio social:

A comunicação dos pais com seus filhos são um aspecto das experiências sociais das crianças que podem ser usadas na construção do conhecimento moral. Explicando a razão das regras e respondendo apropriadamente as violações morais, os pais podem facilitar o desenvolvimento moral estimulando os filhos a pensar reflexivamente sobre suas ações. (Smetana, 1999, p.316).

Por outro lado, a pesquisa de Jimenez e Delgado (2002, p. 225) - que investigou os padrões de comunicação e conflito familiar durante a adolescência - revelou que os adolescentes e seus pais conversam com relativa freqüência sobre os mais relativos assuntos, como, por exemplo, expectativas sobre o futuro, questões do dia a dia, amigos. Os assuntos sobre o domínio moral são mais escassos e conflituosos. Há, entretanto, uma tendência de que 
os filhos costumam a conversar mais com as mães que com os pais. Ainda que as questões de normas e regras sejam geralmente mais tratadas com os pais.

O item 11 também apresentou o posicionamento do juízo moral dos pais que afirmaram concordar $(79,5 \%)$ com a necessidade se controlar para castigar os filhos. Assim, a temática das sansões se apresentou como a grande questão, fonte de maior dificuldade para os pais de acordo com os resultados colhidos por essa pesquisa. Esse resultado foi consistente com o posicionamento piagetiano a respeito da educação moral. Em suas palavras:

Observemos a propósito que um dos aspectos mais delicados da educação moral, e aquele onde existe justamente o maior desvio entre os aspectos de autonomia ou de reciprocidade - formadores de personalidade - e os métodos de autoridade, é precisamente relativo ao problema das sanções. (Piaget, 1948/ 2000, p. 71).

Segundo as respostas ao instrumento, os pais admitiram a necessidade se buscar o autocontrole para decidir a respeito das sanções a serem aplicadas aos seus filhos e também admitiram que os pais sempre devem considerar as explicações dos filhos. Conforme comentado anteriormente, os pais também afirmaram $(58,8 \%)$ que um pai deve ajudar os filhos a arcar com as consequiências dos seus atos (item 24) fazendo a opção pela sansão por reciprocidade.

Pode-se afirmar que há uma intenção por parte dos pais de estabelecerem com os seus filhos, relações de cooperação, pautadas no diálogo, na discussão dos conflitos e nas trocas de ponto de vista. Conforme La Taille (2009, p. 250): “É preciso que uma educação moral digna desse nome seja oferecida a crianças e jovens. E uma educação digna desse nome deve fazer apelo à inteligência dos educandos, fazer apelo a sua reflexão".

Entretanto, esses mesmos pais que optaram pelo juízo de relações justas pautadas em sansões por reciprocidade, admitiram que um pai pode punir fisicamente o seu filho caso ele faça algo muito errado (item 16). Infelizmente, a porcentagem é significativa: 69,7\%.

Esse resultado foi bastante importante para esse instrumento, uma vez que, em outro estudo realizado pela mesma autora (Caetano, 2008) os pais que participaram daquela pesquisa não admitiram verbalmente (a pesquisa foi realizada através da entrevista oral) a utilização da punição física (o índice percentual para a presença da punição física nas estratégias educativas permaneceu na casa dos $30 \%$ ). 
Acredita-se que a natureza do instrumento escrito, e, essa característica que o mesmo tem demonstrado de possibilitar ao participante revelar o seu juízo e também as suas formas de intervenções concretas, viabilizaram a expressão desse resultado ${ }^{35}$.

Conforme se sabe a punição física nasceu na escola e passou para a família. Entretanto, depois de tantos debates entre pais e professores desapareceu das escolas (ao menos existem leis para garantir isso: a constituição federal e o ECA). Todavia, mesmo com leis que condenam a agressão física também na família, infelizmente, a punição física ainda continua sendo considerada eficaz na pedagogia familiar.

Interessante mesmo observar que atualmente existem leis para questões que antes eram consideradas deveres morais. Por exemplo, o próprio Estatuto da Criança e do Adolescente (ECA), nada mais é do que uma lei que afirma aos adultos que eles devem proteger as crianças do mundo. Recentemente foi veiculado na mídia um projeto de lei para obrigar os pais (que não vivem com as mães dos seus filhos) a dispensarem atenção aos seus rebentos. Conforme La Taille (2009, p.192), a "fúria normatizadora" pode ser explicada pelo problema que desencadeia a elaboração de tantas leis:

Só vejo uma explicação: desconfia-se de que as pessoas não se comportarão espontaneamente segundo princípios de respeito, de honestidade, de responsabilidade, de justiça, logo, regras e mais regras devem ser criadas para explicitar as condutas corretas. E, como toda a regra, se transgredida, implica sanção, o recado "cívico" é claro: comporte-se de tal e tal maneira, ou será punido. (La Taille, 2009, p.192).

Dessa forma a necessidade da elaboração de tantos códigos de ética e leis que obriguem inclusive a amar os filhos, expressa com clareza, a ausência das normas morais. Conforme Piaget (1965/1973, p. 228):

A relação moral consiste numa troca de valores desinteressados, porque cada um dos parceiros se coloca no ponto de vista do outro, adotando sua escala, enquanto, na relação jurídica supõe simples conservação de valores adquiridos, do ponto de vista de uma escala comum e geral (a lei habitual ou o código).

O item 5 (quando o filho faz alguma coisa errada, o pai deve proibi-lo de fazer algo que ele goste) também investigou as questões de como os pais pensam as questões das sansões. $72,3 \%$ dos pais concordaram em tirar algo que o filho gosta, quando o mesmo faz algo errado.

\footnotetext{
${ }^{35}$ Interessante anotar que muitos participantes questionaram a pesquisadora se poderiam registrar nas respostas ao instrumento que de vez em quando batiam nos filhos e questionavam se não haveria problema admiti-lo. A resposta da pesquisadora sempre foi: "Você deve responder as perguntas contando como você age. A pesquisa está interessada em compreender como os pais educam os seus filhos".
} 
Esse tipo de sanção intitulada expiatória, é amplamente utilizada pelos genitores, que entendem que reforçando comportamentos adequados e punindo comportamentos negativos, estão formando os seus filhos. Infelizmente, esse tipo de condicionamento não é suficiente para educar moralmente, e pode quando muito dar resultados imediatos, mas não produz tomada de consciência, legitimação de regras e construção de valores.

Atualmente existe inclusive um determinado programa televisivo cujo objetivo é orientar e auxiliar a pais que não conseguem mais "controlar" os seus filhos. A responsável pelo desenvolvimento das orientações à família "confusa, perdida e despreparada", se reveste do pseudônimo "Super", e costuma propor algumas intervenções que são representativas desse tipo de sanções arbitrárias: "cantinho da disciplina" (cadeira na qual as crianças devem se sentar e lá permanecerem depois de pedir desculpas aos pais, quando por exemplo, jogam objetos no chão), “cartaz do bichinho que deve subir a escada" (os pais fazem um macaquinho de papel subir um degrau no cartaz cada vez que a criança obedece).

Obviamente, todos os casos tratados pelo programa são de crianças pequenas. Essas técnicas não funcionariam mais com adolescentes. Uma mãe desesperada relatou que prometeu um carro para o seu filho adolescente de 18 anos, como prêmio caso ele concluísse o ensino médio, mas o "ingrato" disse a ela que nada o compraria.

Dessa forma, a estratégia educativa não resolveu o problema imediato e ainda passou para o filho a mensagem da troca ou "barganha": faça o que eu quero e você será recompensado. Todavia o jovem não se submeteu. O valor do estudo? A importância da formação? O fator inegociável da regra: concluir a educação básica? Essas foram questões que não foram abordadas, e muito menos, discutidas com o jovem.

Pior do que uma sansão expiatória é a negligência. O item 9 (os pais devem contornar os erros dos filhos para não viverem brigando com eles) apresentou aos participantes essa opção de relacionamento com os filhos. A porcentagem de pais que concordaram com a variável somou $80 \%$ dos participantes, sendo que desses, 40,5\% deles, concordaram plenamente. Outra contradição se vislumbrou, pois no item 24 , que tratava de ensinar responsabilidade, ou seja, ensinar os filhos a arcarem com as conseqüências dos próprios atos, a concordância também foi significativa.

A questão da sanção está atrelada a da justiça, porque tem como objetivo levar o culpado a restituir a autoridade da regra, para que não se rompa o elo de solidariedade que sustenta a convivência harmônica com o grupo. Portanto, quando o adulto pune a criança ou o adolescente, deve ter em mente que a atitude tomada deverá demonstrar ao educando que a regra é válida, e por isso, que algo deve ser feito para reparar a regra quebrada, de modo que a 
mesma continue legitimamente organizando as relações com os outros. Seria injusto descumprir uma regra ou combinado e não ter que se responsabilizar pelo dano causado pela infração.

Quando os pais fazem "vistas grossas" às vezes que seus filhos descumprem uma regra, estão deixando de ser autoridade (boas pessoas, fonte de boas regras) e dizendo com a sua negligência que as regras não são tão importantes ou legítimas assim. Por outro lado, quando os próprios adultos pagam o preço no lugar dos filhos, no sentido: "meu filho, faça o que quiser que eu dou conta do prejuízo, seja ele qual for", estão lhes roubando ainda a possibilidade de serem livres e ao mesmo tempo responsáveis: esse tipo de super proteção gera dependência e descompromisso.

Segundo Piaget:

Existe ao contrário uma maneira de infundir confiança ao invés de castigar, recorrendo à reciprocidade mais que à autoridade, que favorece, mais que qualquer imposição ou qualquer disciplina exterior, o desenvolvimento da personalidade moral. (Piaget, 1948/ 2000, p. 72).

O autor se refere à sanção por reciprocidade que supõe que o ato de correção esteja diretamente relacionado à regra que foi descumprida. Esse tipo de atitude quando tomada pelo adulto ajuda o educando a se responsabilizar pelos seus atos, compreendendo a regra, bem como as conseqüências do seu não cumprimento, a partir de um processo de conscientização, legitimação e interiorização dos princípios que compõem a regra. "O espírito de disciplina, entende-se, constitui o ponto de partida de toda a vida moral. É preciso não somente uma certa regularidade na conduta, mas regras e regras revestidas de suficiente autoridade. É a este preço que se desenvolve a personalidade.” (Piaget, 1932/1994, p. 267).

Com relação ao item 19 (um pai que tem dois filhos precisa sempre agir do mesmo modo com os dois) o mais interessante a ser notado foi o fato das respostas terem sido bastante distribuídas. Há os que concordaram e os que não concordaram. A idéia do item foi verificar a questão da justiça distributiva por igualdade, comparada a questão da justiça por equidade.

Obviamente não é possível a um pai agir do mesmo modo com dois filhos. Em se considerando o caráter universal dos princípios que regem as regras trabalhadas pelos pais, realmente deve ser o mesmo. Conforme La Taille (2009, p.225): “Os princípios não dizem como agir, pois essa é a função das regras, mas dizem em nome de que agir”. Sendo um exemplo de princípio: ser justo com as pessoas. 
Segundo La Taille (2009, p.225) "ser justo, ser generoso e ter respeito moral por si próprio e pelos outros correspondem a virtudes morais necessárias”. Esses são os valores universais que os pais precisam auxiliar os seus filhos a construírem. Portanto, é sim possível agir com os filhos segundo os mesmos princípios. Entretanto é impossível agir do mesmo modo com dois filhos diferentes. Cada ser humano é único. Além das diferenças de personalidade de cada filho, há a questão das diferenças de fases de desenvolvimento. Há que se fundamentar a justiça (nesse caso em sua noção mais evoluída, ou seja, distributiva e não retributiva) na forma superior de reciprocidade que é a "equidade": relação baseada não sobre a igualdade pura mas sobre a situação real de cada indivíduo. (Piaget, 1932/1994, p.214).

Finalmente, quanto ao último item (35) que compôs o construto justiça (o pai pode falar e não agir conforme as suas palavras) que apresentou $67,2 \%$ dos participantes concordantes com a assertiva, cabe elencar duas considerações:

A primeira, se refere, mais uma vez à questão que vem sendo demonstrada desde o primeiro construto, mas que, se torna absolutamente clara nesse último item, em relação à oposição entre as representações dos pais sobre o seu papel na educação moral dos filhos, e as suas intervenções concretas. Com bastante sinceridade, os pais afirmaram nesse construto que, embora acreditem que são exemplos para os filhos, afirmaram que um pai pode falar e não agir conforme as suas palavras. $\mathrm{Na}$ verdade, esse item é convergente com as outras respostas, e denota a coerência e a veracidade no preenchimento do instrumento.

$\mathrm{O}$ que se notou, até aqui, especialmente nesse construto de justiça, foi exatamente que, os pais acham que deveriam se controlar para castigar o filho, mas admitiram utilizar a punição física; os pais entendem que devem ajudar os filhos a se responsabilizarem pelos seus atos, mas usam recompensas e castigos, ao invés do processo reflexivo e de sanções por reciprocidade.

Dessa forma, afirmar que um pai pode falar e não agir conforme as suas palavras é confirmar exatamente o que esse instrumento demonstrou ser a maior dificuldade dos pais no processo educativo dos filhos: adequar as intervenções e ações junto aos filhos de modo a verdadeiramente atingir os seus próprios objetivos, que é auxiliar os filhos a se tornarem pessoas autônomas. Sendo o problema das sanções o mais complexo para essa amostra.

A segunda reflexão, em relação ao resultado desse item é a idéia inerente ao desafio de ser educador, sem qualquer tipo de formação para isso. O que sabem sobre valores, princípios, ou regras? O que compreendem sobre desenvolvimento moral? $\mathrm{O}$ que sabem sobre as características de um adolescente? 
Seguem os estudos do construto autonomia, bem como os respectivos histogramas para os resultados obtidos em cada variável que compõe o construto, conforme o quadro 14.

\begin{tabular}{|l|}
\hline \multicolumn{1}{|c|}{ AUTONOMIA } \\
\hline 6- É fundamental que os pais conversem com seus filhos. \\
\hline 7- Cabe aos pais tomar as decisões pelos filhos. \\
\hline 13- Os filhos, quando autorizados pelos pais, devem ter suas próprias experiências. \\
\hline $\begin{array}{l}\text { 21- Os pais devem ajudar os filhos a refletirem sobre as suas ações ao invés de lhes } \\
\text { dar ordens. }\end{array}$ \\
\hline 25- Nem sempre um pai deve oferecer escolhas aos seus filhos. \\
\hline 32- Não se pode sempre ouvir os filhos. \\
\hline 33- Os pais devem acatar as opiniões dos filhos. \\
\hline 34- Os pais devem substituir os “longos sermões" por poucas palavras. \\
\hline
\end{tabular}

A autonomia como construto, na adolescência, pode tomar diferentes formas na relação com os pais, com os pares e com os pares românticos. Segundo Gooness (2006) muitos estudiosos concordam que existem três diferentes tipos de autonomia estudados nas pesquisas sobre a relação pais e adolescentes. O problema é que, existem divergências a respeito do conceito e da natureza dos três tipos de autonomia, o que amplia a complexidade desse tema de pesquisa. A distinção clássica apresentada aqui costuma ser a mais adotada pelos pesquisadores:

Autonomia comportamental: se refere à ação e a todas as manifestações de funcionamento independente, incluindo a regulação do próprio comportamento e a tomada de decisões.

Autonomia emocional: é descrita e abordada pela abordagem psicanalítica, e implica no controle emocional que o adolescente tende a adquirir, a partir da desconexão e do abandono do modelo dos pais como figuras onipotentes e fonte de conselhos e orientação para o adolescente.

Valores autônomos: refere-se ao desenvolvimento do próprio sistema de valores e desenvolvimento moral. (Goossens, 2006, p. 136)

Entretanto, conforme, a revisão das pesquisas que se ocupam desses temas, observa-se que há um limitado número de estudos que investigam esse último aspecto, ou seja às 
questões relacionadas aos valores morais e a autonomia cognitiva, que é a abordagem dada para a presente pesquisa.

Segue o histograma com as respostas ao item Autonomia

Quadro 15 - Histograma dos itens que compõem AUTONOMIA

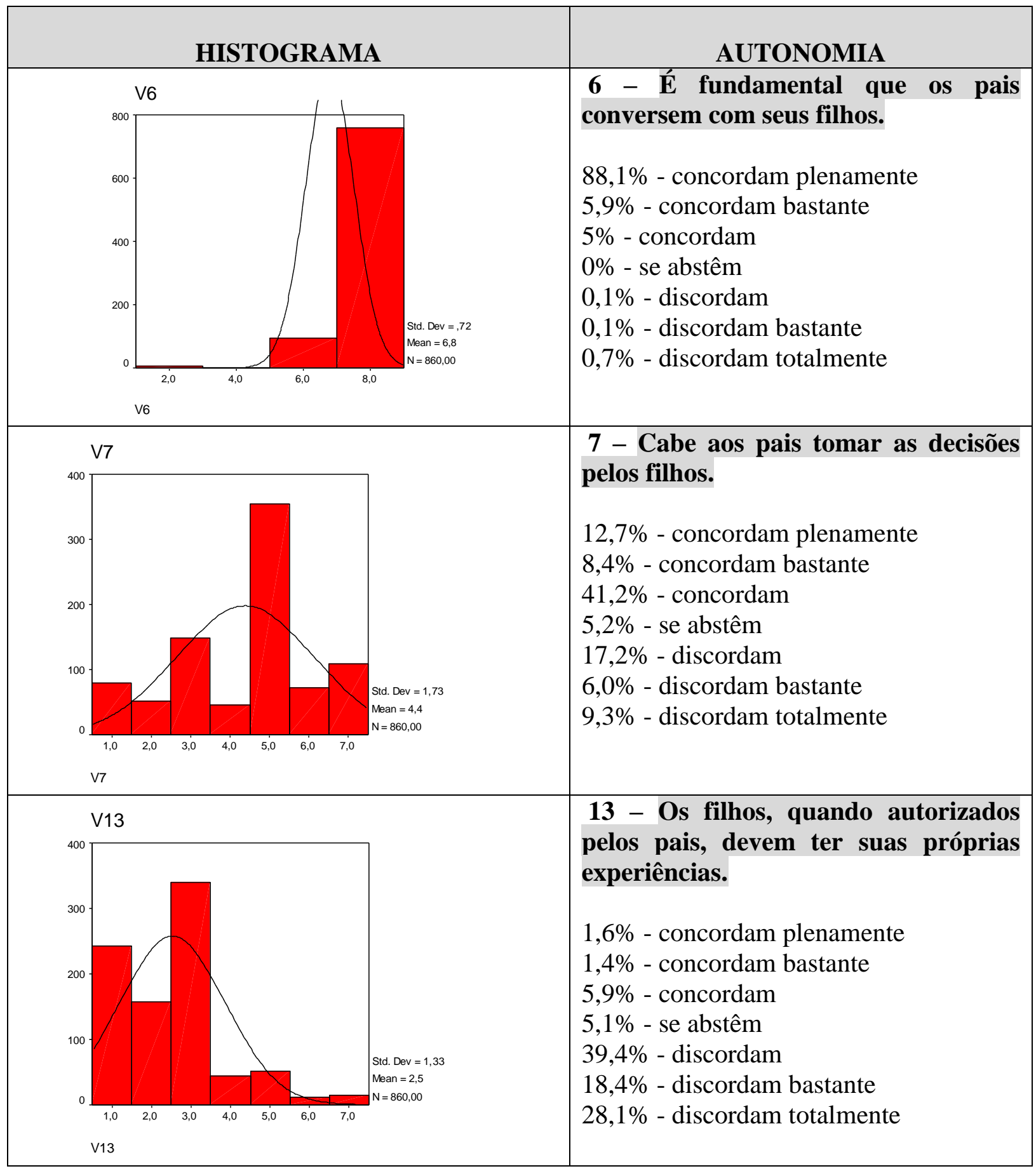




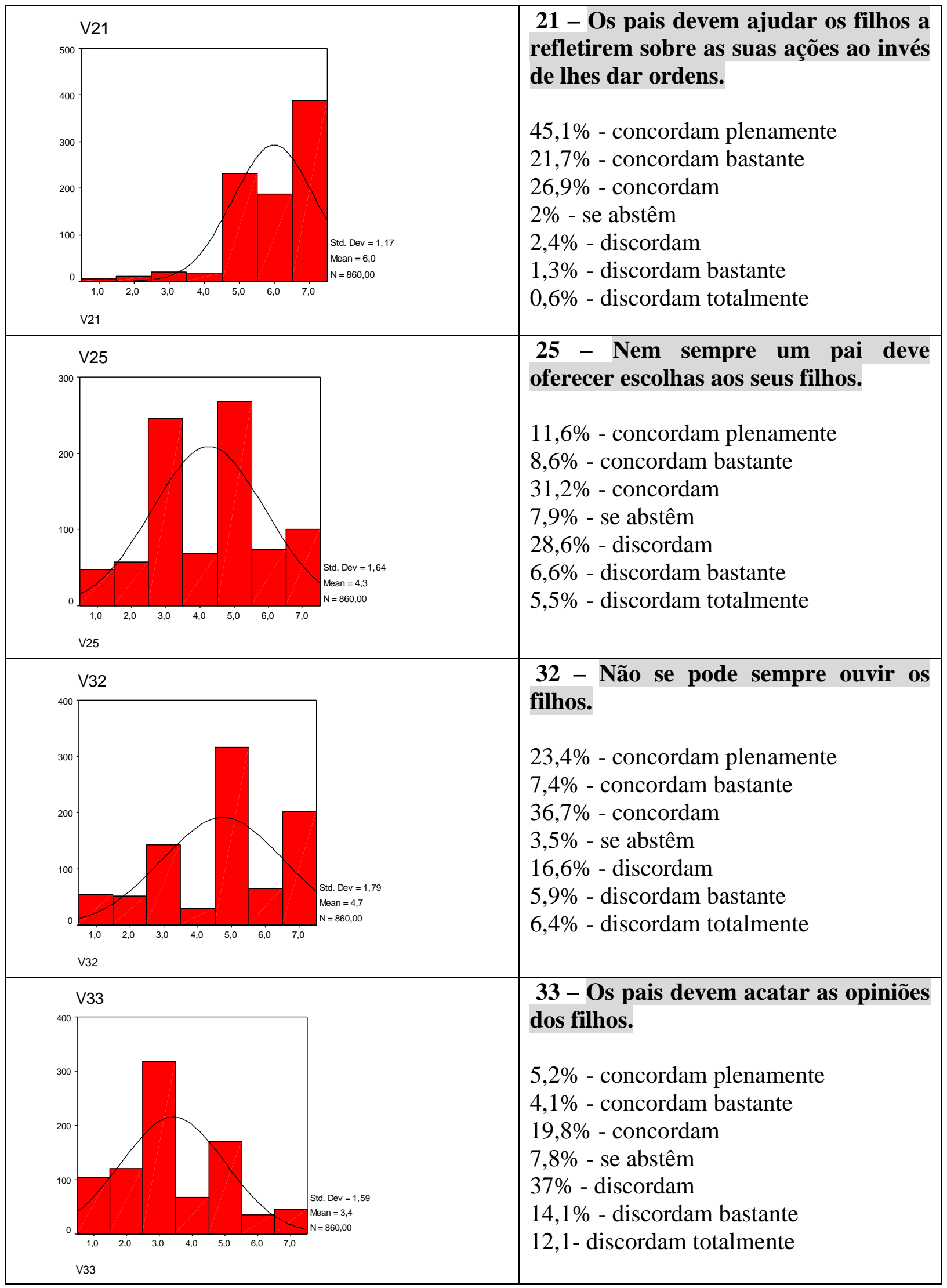




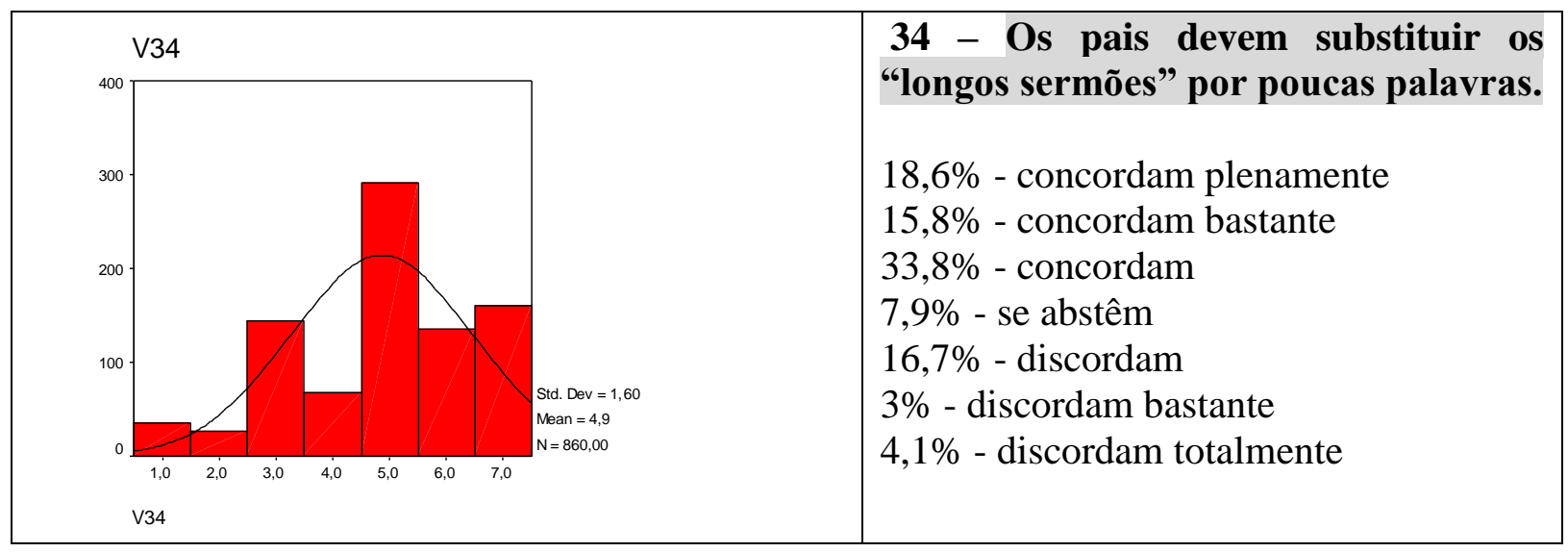

Conforme abordado pelo quarto capítulo desse texto, o construto autonomia, nesse caso, se fundamenta no conceito piagetiano de autonomia como finalidade máxima de todo processo educativo. "Piaget afirma que o ser autônomo somente legitima princípios e regras inspiradas pela reciprocidade, pela igualdade, pela eqüidade e pelo respeito mútuo”. (La Taille, 2006, p. 21). Portanto, para Inhelder e Piaget (1970/1976, p. 260) ser autônomo implica em construir um conjunto de valores que, hierarquicamente organizados, possam conduzir a elaboração de um plano de vida que permitirá ao adolescente a sua integração no universo social adulto.

Para Piaget, a construção da autonomia moral pressupõe que o adolescente vivencie relações de cooperação. Portanto, para ele, o tipo de relação social vivenciada terá grande influencia sobre o desenvolvimento moral. Conforme suas próprias palavras:

E, realmente, a personalidade implica em cooperação; a autonomia da pessoa opõe-se ao mesmo tempo à anomia, ou ausência de regras (o eu) e a à heteronomia, ou submissão às regras impostas do exterior. Nesse sentido, a pessoa é solidária com as relações sociais que mantém e produz. (Piaget, 1964/1986, p. 65-66).

Dessa forma, o construto que se apresenta procurou mensurar como os pais pensam as suas relações com os filhos no tocante a facilitar a construção da autonomia. E, mais uma vez o que se notou foi a existência de um juízo positivo em relação à construção de um ideal de desenvolvimento autônomo dos adolescentes atrelado a dificuldade das ações concretas.

Assim, os itens: 6 (é fundamental que os pais conversem com os filhos) com o qual 99\% dos participantes concordaram, item 21 (os pais devem ajudar os filhos a refletirem sobre as suas ações ao invés de lhes dar ordens) que assumiu 93,7\% da concordância dos pais, item 34 (os pais devem substituir os longos sermões por poucas palavras) que contou com $68,2 \%$ das respostas concordantes e o item 13 (os filhos quando autorizados pelos pais devem ter suas 
próprias experiências) cujas respostas somaram 85,9\% de discordância; são reveladores dessa intenção dos pais de formar seus filhos no sentido de uma educação autônoma.

Entretanto, quando observamos esses itens anteriormente apresentados em comparação com os demais itens que compuseram o construto autonomia, a dificuldade em conciliar o juízo e ação se explicita mais uma vez. Por exemplo, os pais admitiram em unanimidade (99\%) que é fundamental que os pais conversem com os filhos (item 6), todavia, no item 32 (não se pode sempre ouvir os filhos), 67,5\% dos mesmos pais, admitiram que não podem ou não conseguem, ouvir os próprios filhos.

Ora, se a autonomia é fruto de relações de cooperação, o diálogo é absolutamente indispensável para o processo de troca de pontos de vista, de argumentação racional a respeito dos princípios norteadores das regras e até mesmo, a atenção e o afeto disponibilizados no momento de ouvir o adolescente são significativos para o desenvolvimento moral. Conforme, Smetana (1999, p.314) argumentando a respeito do papel dos pais no desenvolvimento moral, o contexto afetivo das interações com os pais e os fatores cognitivos das respostas dos pais para os conflitos morais são importantes para a construção de uma maior maturidade dos conceitos morais dos filhos.

Por outro lado, quando os pais no item 7 , concordaram $(62,3 \%)$ que "cabe aos pais tomar decisões pelos filhos", também contradisseram a idéia assumida a respeito da educação para a autonomia. Pesquisas a respeito da temática das tomadas de decisões, têm sido realizadas no âmbito da teoria dos domínios sociais, sendo que a pesquisa de Smetana, Campione-Barr e Daddis, (2004) é um exemplo desse tipo de investigação. As autoras realizaram um estudo longitudinal com adolescentes afro-americanos de classe média, definindo o comportamento autônomo saudável a partir do desenvolvimento da tomada de decisão no âmbito familiar.

A investigação analisou o impacto dos estilos de tomada de decisão: jovem-sozinho (quando o adolescente toma decisões sem nenhuma participação dos pais); decisão unilateral dos pais (quando os pais tomam decisões sem nenhuma participação dos filhos); decisão conjunta, em relação a questões pertencentes ao domínio convencional (responder aos pais, boas maneiras, realização das tarefas escolares), prudencial (fumar cigarros, comer comida de fast food, usar bebidas alcoólicas, usar o carro), multifacetado (aparência física, limpar o próprio quarto, escolha dos amigos, garotos usar brincos, usar pircings e tatuagens) e pessoal (escolha dos programas de TV, como gastar a mesada, escolha das músicas, quais roupas usar). 
A questão do domínio moral não foi investigada pela pesquisa de Smetana, CampioneBarr e Daddis, (2004), uma vez que os resultados de pesquisas anteriores, entre elas, Smetana e Asquith (1994), indicaram que adolescentes e pais julgam legítima a autoridade parental a respeito das questões do domínio moral representados pelos seguintes itens: pegar dinheiro dos pais sem permissão, bater no irmão ou irmã, mentir para os pais, quebrar promessas com os pais.

Conforme, os estudos de Piaget (1932/1994), esses itens anteriores apontados para representar o domínio moral, não serviriam para orientar a temática da moral autonomia, pois o não mentir, não roubar, não trair, não desrespeitar, não agredir, se constituem como deveres universais e não deveriam estar como na pesquisa, endereçados aos pais. Nesse caso pode-se afirmar que a investigação de Smetana e Asquith (1994) dizia respeito a questões heterônomas, nas quais a justiça e o respeito estariam atrelados à autoridade.

Realmente, conforme o resultado dessas pesquisas, o conflito entre pais e filhos na adolescência está sempre relacionado ao seguinte fato: pais e adolescentes concordam a respeito da legitimidade do papel da autoridade dos pais nos domínios convencionais e prudenciais, por outro lado os adolescentes legitimam que estão aptos para decidirem algumas questões do âmbito pessoal. Todavia a dificuldade é que para ambos, pais e adolescentes, há um desencontro a respeito da fronteira entre o que é da jurisdição do domínio pessoal e o pertence ao domínio convencional.

Os pais tratam algumas idéias (quando o quarto deve ser limpo, se o adolescente deve fazer tatuagens, ou usar pircing, sobre o adolescente ver amigos indesejáveis, ou quando o adolescente pode começar a namorar) como sócio- convencionais (ou prudenciais) enquanto o adolescente as trata como pessoais. (Smetana, CampioneBarr e Daddis, 2004, p. 1420).

Os resultados da pesquisa longitudinal relatada sobre as diferentes formas de tomadas de decisões familiares e sua relação com a construção saudável do comportamento autônomo do adolescente, indicaram que o desenvolvimento da autonomia a respeito das decisões do domínio pessoal implicou diretamente em influências significativas sobre questões como depressão, auto-estima e auto-respeito no final de adolescência. Portanto em relação à tomada de decisões dos adolescentes a respeito das questões do domínio social:

Os resultados sugeriram que, menos autonomia no início da adolescência, conectou-se com aumento da autonomia do meio para o fim da adolescência e com a predição de uma otimização do ajustamento do adolescente (melhor autoesima e menos depressão). (Smetana, Campione-Barr e Daddis, 2004, p. 1430). 
A contribuição dessas investigações está na definição de conteúdos para os conflitos entre pais e adolescentes e das concepções tanto de adolescentes como dos pais deles, sobre a autonomia comportamental, sobre a autoridade parental e as formas de tomadas de decisões escolhidas pela família. Quanto aos conteúdos, ou seja, a dificuldade que os pais têm em definir o que é certo ou errado, o que podem ou não podem deixar o seu filho fazer ou escolher, são aspectos consistentes com os resultados da presente pesquisa, uma vez que a grande dificuldade dos pais dessa amostra, está exatamente nas intervenções concretas junto aos adolescentes.

O problema de dar escolhas aos filhos, e quais escolhas, foi representado pelo item 25 (nem sempre um pai deve oferecer escolhas aos seus filhos) da Escala de Concepções Educativas, para o qual as respostas ficaram bastante divididas como se pode observar no quadro 15. As frequiências percentuais revelaram a dificuldade dos pais em relação à temática: $11,6 \%$ concordaram plenamente que os pais nem sempre deve oferecer escolhas aos seus filhos, 8,6\% concordaram bastante, 31,2\% apenas concordaram com a idéia, 28,6\% discordaram, 6,6\% discordaram bastante e 5,5\% discordaram totalmente. Ainda houve 7,9\% da amostra que se absteve de responder. As pesquisas mencionadas anteriormente demonstraram o porquê da parcialidade das respostas. Os questionamentos a respeito de em quais tipos de situações se devem oferecer escolhas aos filhos, pode explicar a diferenciação das respostas.

Entretanto, considerando a proposta da teoria do juízo moral de Jean Piaget, para ser autônomo o sujeito precisa experimentar as escolhas. Ser autônomo implica em liberdade, e, aquele que é livre, o é para fazer as suas escolhas. A possibilidade de fazer escolha é fundamental à construção da autonomia. Quem não faz escolhas, se submete as escolhas alheias. Quem não realiza escolhas não se responsabiliza. Conforme La Taille (2006, p. 224): “A dimensão racional da moral está intimamente relacionada à questão da liberdade, e somente usufrui de liberdade quem pode escolher como vai se comportar".

Assim, a grande questão não seria o domínio das escolhas mas, a habilidade dos pais de oferecer escolhas aos filhos, no lugar das ordens, uma vez que não vale oferecer aos filhos quaisquer escolhas, mas escolhas que garantam o cumprimento das regras. $\mathrm{O}$ exemplo a seguir, pode ilustrar a complexidade da questão.

Uma mãe relatou que pagava a faculdade do seu filho de 19 anos, que cursava direito no período da manhã e fazia estágio a tarde. O filho veio conversar com os pais, argumentando que gostaria de transferir o curso para o período da noite, argumentando que 
conforme a situação se configurava, ele chegava cansado ao estágio, e, portanto, se estudasse a noite, poderia se dedicar ao trabalho durante o dia.

Os pais o ouviram atenciosamente e então deram a sua opinião: “mas, se o problema é chegar cansado no estágio, entendemos que se você alterar o horário, estará realmente mais descansado para o estágio, porém menos disposto para a faculdade à noite, e, segundo a nossa opinião, a prioridade é a sua formação, portanto, que o seu melhor seja dado ao curso e não ao estágio”. O jovem voltou a argumentar, dizendo que, se dedicasse o dia ao estágio, ampliaria as possibilidades de ganhos financeiros. Os pais novamente o ouviram e lhe propuseram a seguinte escolha: "acreditamos que a tomada de decisão é sua. Mas, queremos lhe sugerir que escolha entre a oportunidade que estamos the oferecendo de cursar a faculdade com excelência (uma vez que estamos the pagando o curso, e o estágio lhe oferece uma remuneração extra, além da possibilidade da experiência), e a sua decisão de investir maior energia no trabalho. Sendo a sua opção a segunda, arcará com as conseqüências dela, e uma vez com maior remuneração, passará a arcar também com as despesas da faculdade”.

A princípio a escolha oferecida pelos pais, pode parecer arbitrária, mas de fato não é. Arbitrário seria dizer para o filho: "você não vai estudar a noite, nem pense isso, pois esse tipo de decisão não é da sua conta porque quem paga essa faculdade somos nós". A discussão saudável e a possibilidade garantida ao jovem de argumentar e de escolher, levam a reflexão, a tomada de consciência e principalmente, a possibilidade de arcar com as consequiências de sua escolha. Quanto ao valor do estudo, ficou garantido pela atitude e coerência dos pais. O jovem ainda se mostrou irritadiço e expressou seus sentimentos dizendo que os pais somente estavam pensando em dinheiro, ao que, os pais simplesmente responderam: "em nenhum momento lhe propusemos pararmos de pagar os seus estudos. Nós realmente valorizamos a importância de lhe oferecer a melhor faculdade e, por esse motivo, estamos deixando você escolher".

Esse exemplo ainda pode servir também de ilustração para o item 33 (os pais devem acatar as opiniões dos filhos). Os pais do exemplo acima ouviram a opinião e os argumentos do filho, entretanto, nem sempre é possível acatar os argumentos dos filhos. O rapaz teve garantido o seu espaço de argumentação e escolha. Todavia, a atitude dos pais demonstrou a legitimidade do valor do estudo, uma vez que a sua intervenção deixou isso bastante claro para o filho.

Conforme as palavras de La Taille (2009, p. 46): “Adultos podem ter algumas provisões, reservas de valores para orientar suas vidas, seus filhos não". Isso poderia ser dito de outra maneira: os pais são os adultos da relação. Assim, o papel dos pais é de oferecer escolhas sim, 
de possibilitar aos filhos adolescentes essa liberdade que implica na responsabilidade. Infelizmente, alguns pais, porque vêem seus filhos com corpos de adultos, acabam pensando que esses moços e moças não precisam mais deles, ou por dificuldade em trabalhar a questão da autoridade versus autoritarismo, optam pela omissão.

Portanto, esses quatro últimos itens comentados $(7,32,33,25)$ refletem então que educar para a autonomia não é tão simples quanto desejar fazê-lo.

\subsubsection{Sobre os itens ou variáveis eliminados}

A eliminação de itens como medida para ajustar o modelo do instrumento, se fundamentou, nos resultados do tratamento estatístico, assim, os resíduos muito altos, bem como as medidas de ajustamento do modelo (ver quadro 8 do capítulo 7 e o anexo 4) foram indicadores estatísticos que sugeriram que determinados itens ou variáveis não estavam se ajustando ao modelo.

Entretanto, todas as decisões tomadas pelo pesquisador, também levaram em conta além dos critérios matemáticos descritos no parágrafo anterior, critérios teóricos, fundamentados na teoria do desenvolvimento do juízo moral, no caso dessa pesquisa.

Dessa forma, pode-se afirmar que:

- O Modelo eliminou variáveis que apresentaram a escrita com idéia dúbia e que pode causar dupla interpretação como é o caso do item 2: um pai nunca deve mexer nas coisas do filho sem pedir permissão. Há duas idéias a serem avaliadas: mexer nas coisas do filho e pedir permissão para mexer nas coisas do filho. O mesmo se passou com o item 36: os filhos devem respeitar os pais mesmo que os seus pais não os respeitem. São duas idéias também: filhos devem respeitar os pais e pais devem respeitar os filhos, o que pode confundir os respondentes. O item 29: cabe aos pais darem soluções para as situações difíceis pelas quais passam seus filhos, também apresentou duas idéias: cabe aos pais darem soluções para os filhos, cabe aos pais darem soluções para situações difíceis.

- O modelo eliminou a questão de incompatibilidade teórica como no item 4: é fundamental que a ordem dada pelos pais, seja acompanhada de explicação. Quem dá uma ordem não a explica. A idéia de ordem já implica na coação. Quem explica é porque tem uma orientação a fazer e não uma ordem a impor.

- O modelo também eliminou variáveis parecidas com outras que permaneceram no modelo. Um dos objetivos da Análise Fatorial Confirmatória (CFA) é justamente o refinamento de escalas (MacCallun \& Austin, 2000, p.208). Assim, os itens abaixo são 
bastante parecidos (ou buscam mensurar o mesmo construto) com outros que permaneceram na escala, por estarem melhor formulados e se ajustarem melhor ao modelo:

$>$ Item 30: os filhos que amam seus pais sempre devem lhes obedecer (semelhante ao item 8 de obediência);

$>$ Item 10: os pais devem usar ofensas quando necessário para educar seus filhos (semelhante ao item 16 de justiça);

$>$ Item 15: os pais devem sempre se esforçar para entender as razões de desobediência dos seus filhos (semelhante ao item 3 de justiça);

Item 27: os pais devem sempre permitir que seus filhos busquem soluções para os seus próprios problemas (semelhante ao item 24 de justiça).

- O modelo eliminou variáveis que contavam com expressões que poderiam causar confusão para os respondentes. A variável 20: um pai nem sempre deve trocar idéias com seus filhos, cuja expressão problemática é "trocar idéias". Qual o significado de trocar idéias? Pode ser interpretado das mais diversas formas. O item 18: os pais sempre sabem o que é melhor para o seu filho, sendo a expressão "o que é melhor para o filho", aquela que pode conduzir a diferentes interpretações. O item 22: um filho sempre deve acatar as ordens dos pais, traz a palavra acatar como dificultosa do entendimento. 


\section{2- Estudo das tendências segundo as variáveis dependentes}

O estudo das tendências segundo as variáveis dependentes teve como objetivo compreender diferentes dimensões do interior das amostras, bem como investigar os resultados no sentido de buscar indícios de validade convergente para o instrumento.

Uma vez que a amostra contou com a participação de pais e mães das cinco regiões do Brasil, a análise das relações entre as variáveis que caracterizaram a amostra contribuiu bastante para a compreensão de como os pais brasileiros estão pensando a educação dos seus filhos, bem como que influências podem ter o gênero ou a idade dos participantes, entre outras variáveis na definição das suas respostas.

Esse capítulo apresenta os resultados referentes a:

1. As relações (quanto à significância estatística) entre as variáveis: gênero, número de filhos, estado civil, profissão, escolaridade dos pais, renda familiar e idade dos participantes e às respostas aos constructos;

2. As relações (quanto à significância estatística) entre as variáveis: tipo de escola na qual os adolescentes estudam (pública e privada), lugares pesquisados (regiões sul, norte, nordeste, centro-oeste, sudeste do Brasil) e às respostas aos constructos.

Os testes estatísticos utilizados para o estudo das significâncias entre as variáveis dependentes e as respostas aos construtos foram:

Kolmogorov Smirnov Test (Levin, 1987): utilizado para a verificação da aderência dos dados à distribuição normal e definição dos testes subseqüentes. Os construtos respeito, autonomia e justiça apresentaram aderência à distribuição normal $(\mathrm{p} \geq 0,05)$. $O$ construto obediência não $(\mathrm{p}=0,006)$. Logo, para os primeiros foram utilizados testes estatísticos paramétricos e para o construto autonomia: testes não-paramétricos.

Portanto, para avaliar as relações de significância estatística entre as variáveis dependentes e as respostas aos construtos, foram utilizados os seguintes testes: Mann Whitney Test (Siegel, 1979), Anova (Maroco, 2003), Tukey Test (Maroco, 2003), Kruskal Wallis Test (Siegel, 1979).

Os resultados serão apresentados da seguinte maneira: em primeiro lugar são apresentadas as variáveis para as quais as relações não foram significativas e em segundo lugar, as variáveis cujas relações foram significativas estatisticamente. 


\subsubsection{Variáveis que não apresentaram significância estatística}

1- Gênero

Há uma tendência bastante considerável em acreditar que a forma dos pais educarem é diferente da forma como as mães educam. Para essa pesquisa, não houve significância estatística $(p \geq 0,005)$ em relação as respostas aos construtos de pais e de mães. Entretanto, isso pode ter sido influenciado, matematicamente, pelo fato de que o número de mães participantes (683) representar 80\% da amostra. Conforme foi anunciado nos procedimentos da pesquisa, os dados foram colhidos nas escolas, durante momentos de reunião de pais, e, desse modo, a participação das mães nesses momentos ainda é maioria.

Ainda que se tenha passado por tantas transformações no conceito de família, e atualmente existam famílias "co-parentais", "recompostas", "biparentais", "multiparentais", "pluriparentais", "monoparentais", enfim, uma difusão de terminologias derivada do termo “parentalidade", explicados por Roudinesco (2003, p.155); a questão da educação dos filhos parece ainda ser uma responsabilidade feminina.

Com relação às pesquisas norte-americanas, a diferença de gênero é bastante presente nos resultados. Inclusive, há uma tendência bem maior de que os adolescentes conversem por exemplo mais com as suas mães, do que com os seus pais. (Youniss e Smolar, 1985); e como há uma tendência de se encontrar diferenças nas questões de gênero em relação ao relacionamento parental com os adolescentes, surpreendentemente, há poucas pesquisas incluindo pais, ou examinando a influência de pais e mães no desenvolvimento do adolescente. (Smetana, Campione-Barr, Metzger, 2006).

Para essa pesquisa também houve bastante dificuldade para conseguir a opinião dos pais. Devido o procedimento utilizado, ou seja, a realização da pesquisa na escola, não se pôde controlar a equiparação do número de pais ao número de mães participantes.

Com relação aos estudos de desenvolvimento moral, especialmente, a questão do gênero foi amplamente discutida especialmente pelas pesquisas de Gilligan (1982, 1988). A idéia da abordagem da autora criou bastante controvérsia. Outros estudos foram realizados a respeito de maturidade moral e orientação moral, entretanto, não se encontrou diferenças de gênero para a maturidade moral e apenas uma tendência maior das meninas adolescentes para uma orientação moral voltada para o cuidado. Porém, não há evidências de que o gênero induza a alguma diferença no desenvolvimento moral. (Lehalle, 2006, p. 129). 


\section{2- $\quad$ Estado Civil}

A mesma observação pode ser realizada com respeito ao estado civil dos participantes e a relação entre eles e as respostas aos construtos: não houve significância estatística ( $\mathrm{p} \geq$ 0,005). Existe uma tendência também, especialmente por parte das escolas, de culpabilizarem as famílias pelos problemas de indisciplina das crianças. Dessa forma, os professores costumam afirmar que os filhos de famílias "problemáticas" ou "atípicas", costumam apresentar maiores dificuldades de convivência nos ambientes escolares. (Sayão e Aquino, 2006, p. 101).

Com relação a essa amostra não houve comprovação de que pais divorciados, por exemplo, pensassem diferentemente sobre as relações de respeito, obediência, justiça e autonomia. Entretanto, a amostra foi composta de $71,3 \%$ de pais casados. Não se buscou investigar nesses participantes se suas famílias eram de primeira, segunda ou terceira união, ou compostas de pais homossexuais, por exemplo.

A única relação com significância estatística que se observou foi à diferença no modo de pensar o respeito $(\mathrm{p}=0,008)$ e a justiça $(\mathrm{p}=0,000)$, dos pais solteiros em relação aos pais casados. Desse modo, para essa amostra houve uma tendência de que os solteiros respondessem menos a justiça e ao respeito que os casados. Portanto, a média das respostas dos pais solteiros aos construtos de justiça e respeito, é menor que a média das respostas dadas pelos pais casados aos mesmos construtos.

Segundo um estudo realizado por Dornbusch et al (1985), utilizando uma amostragem nacional de adolescentes norte-americanos que investigou as inter relações entre a estrutura familiar, modelos de tomadas de decisão na família e desvios de comportamento entre adolescentes, os resultados não foram diferentes.

Há que se considerar que os objetos das pesquisas são diferentes, bem como a amostra é também de países diferentes. Entretanto os dados do estudo norte-americano revelaram também uma dificuldade maior para os pais solteiros (a pesquisa investigou, na maioria, mães biológicas que educam sozinhas os seus filhos, e não questionou a presença de um padrasto; em comparação com famílias que contam com os dois pais biológicos). Segundo os resultados, há um aumento dos comportamentos de desvio dos jovens nas casas de mães solteiras e parece que o principal motivo é a ausência do segundo adulto. (Dornbusch et al, 1985, p.332). O estudo ainda revelou que há uma tendência para o impacto da estrutura 
familiar ser mais forte sobre os adolescentes do sexo masculino e que as relações entre mães solteiras e suas filhas, tendem a ser mais estáveis.

3- Idade dos Participantes

Outra variável para qual não se encontrou significância estatística $(p \geq 0,005)$ em relação às respostas aos construtos foi à idade dos participantes. 79,9\% dos participantes têm entre 30 a 49 anos. Essa pesquisa não investigou diferentes respostas aos construtos com relação à idade dos filhos adolescentes dos participantes. Apenas avaliou as relações com respeito à idade dos participantes, sendo essa uma sugestão pertinente para pesquisas posteriores, uma vez que a questão da idade do jovem é bastante significativa em vários estudos atuais a respeito do desenvolvimento do adolescente. Conforme a revisão teórica e empírica de Smetana, Campione-Barr, Metzger (2006, p.258):

Muitas pesquisas têm dividido a adolescência em três períodos de desenvolvimento, implicando em início da adolescência (idade entre 10 e 13 anos), média adolescência (idade entre 14-17 anos) e final da adolescência (18 anos até os primeiros 20 anos). É comum dizer que a adolescência começa na biologia e termina na cultura, porque a transição para adolescência é feita pelas dramáticas transformações biológicas da puberdade, enquanto a transição para a idade adulta é menos claramente demarcada.

A questão da importância da idade dos adolescentes é tão discutida atualmente que há inclusive estudos que propõem que o período entre 18 e 25 anos seja tratado como um período específico do desenvolvimento. Todavia a maioria das pesquisas sobre o desenvolvimento adolescente tem focado especialmente o início e o meio da adolescência e encontra diferenças a respeito, por exemplo, do aumento das discussões e conflitos com os pais no início da adolescência em detrimento as outras fases da adolescência. (Smetana, Campione-Barr, Metzger, 2006, p.258).

Portanto, mais importante do que a idade dos adultos (pais e mães) parece ser a idade dos adolescentes, enquanto variável significativa para os resultados de novas investigações.

4- $\quad$ Número de filhos

A última variável para qual não se encontrou diferenças significativas estatisticamente $(\mathrm{p} \geq 0,005)$, foi a relação entre as respostas dos genitores e o número de filhos. Para essa amostra, pode se afirmar que os brasileiros têm em média 2 filhos (46,3\% da amostra). A 
idéia de que cada vez mais há a tendência dos adultos terem filhos únicos ou não terem filhos não se comprovou nessa amostra. Essa pode ser uma realidade de uma porcentagem pequena de pais brasileiros que compõem a classe média ou a classe alta desse país.

Com relação à idéia bastante disseminada de que a classe baixa continua tendo um número grande de filhos, também não se confirmou. Essa amostra conta com 32,2\% dos seus participantes com renda familiar de até dois salários mínimos e o número de participantes com mais de 4 filhos para essa amostra, representou apenas $0,8 \%$ dos pais pesquisados.

Entretanto, conforme Steinberg (2001, p. 5) em um estudo intitulado: "Nós sabemos algumas coisas: relação pais e adolescentes em retrospectiva e perspectivas", o autor afirma que as pesquisas revelaram que pais, mães e adolescentes podem experimentar as interações de uns com os outros de diferentes formas, e que estudos sobre as relações com os irmãos demonstram que dois irmãos podem experimentar o contexto familiar de diferentes formas. Desse modo as investigações a respeito das relações entre pais e adolescentes, em relação ao número de filhos, bem como a posição do filho (filho único, primeiro filho, caçula, filho do meio, etc) e o desenvolvimento moral, são sugestões bastante importantes como tipos de pesquisas que ainda não foram realizadas no Brasil.

\subsubsection{Variáveis que apresentaram significância estatística}

1- $\quad$ Renda Familiar

Há uma tendência bastante considerável em acreditar que as dificuldades econômicas e sociais influenciam a educação dos filhos. Para essa pesquisa houve significância estatística $(\mathrm{p}=0,000)$ em relação à renda familiar dos participantes e suas respostas aos construtos. A maior parte dos participantes tinha renda média familiar respectivamente: 32,2\% têm renda familiar de até 2 salários mínimos e 28,8\% têm renda familiar entre 2 a 5 salários mínimos.

Há ainda 18,5\% dos participantes que afirmaram ter renda familiar entre 5 e 10 salários mínimos, $13,5 \%$ que afirmaram ter renda média entre 10 e 20 salários mínimos e 7\%, afirmaram ter renda superior a 20 salários mínimos. Conforme os dados estatísticos, houve significância estatística $(\mathrm{p}=0,000)$ para as respostas dadas por cada extrato da amostra em relação aos outros extratos, assim, como em relação aos quatro construtos. Portanto, a renda familiar é uma variável que influenciou a forma dos pais e mães do nosso país compreender a educação dos seus filhos. 
A relação observada foi que, quanto menor a renda familiar, menor a média de respostas atribuídas para os construtos: respeito, justiça e autonomia e maior a média de respostas atribuídas ao construto da obediência. Por outro lado, os pais com rendas familiares mais altas, deram respostas com média mais baixa para a obediência e respostas com média mais alta para os construtos: justiça, respeito e autonomia.

Portanto, os dados revelaram que há uma maior tendência por parte dos pais brasileiros que possuem baixa renda familiar, de estabelecer com seus filhos relações mais coercitivas, pautadas no incentivo a obediência, através do respeito unilateral e das sanções expiatórias. Uma vez que essa é a condição de $61 \%$ dos participantes (situados nesse estrato de baixa renda familiar) é possível afirmar que esses dados são convergentes com os resultados discutidos anteriormente na segunda parte desse mesmo capítulo (que analisou as respostas dos participantes para cada construto).

Os dados dessa pesquisa foram consistentes com os dados da pesquisa de Lins-Dyer e Nucci (2007), realizada com participantes do nordeste do Brasil, sobre o impacto das classes sociais sobre as respostas de mães e filhas a respeito das suas concepções sobre controle parental. Os resultados da pesquisa demonstraram que filhas de classes sociais mais baixas perceberam que suas mães exerciam maior controle sobre elas que as filhas de classe média. Por outro lado, as mães de classe baixa requisitaram maior índice de controle sobre problemas convencionais e prudenciais que as mães de classe média.

2- Formação escolar dos pais

Coerentemente com os resultados da variável anterior, o que mais uma vez implica em uma validade convergente do instrumento, houve significância estatística $(p=0,000)$ em relação à formação dos participantes e suas respostas aos construtos. Os participantes apresentaram os seguintes percentuais para a variável formação escolar: 22,4\% não têm formação, $12 \%$ têm ensino fundamental completo, $32,4 \%$ têm ensino médio completo, $24,1 \%$ têm ensino superior e 9,1\% têm formação em pós-graduação.

A relação observada foi que, quanto menos formação escolar, menor a média de respostas atribuídas para os construtos: respeito, justiça e autonomia e maior a média de respostas atribuídas ao construto da obediência. Por outro lado, os pais com formação escolar mais completa deram respostas cuja média foi mai baixa para a obediência e respostas cuja média foi mais alta para os construtos: justiça, respeito e autonomia. 
Essa variável está muito atrelada à questão da grande necessidade de que os pais tenham mais conhecimentos para educar seus filhos. Até pouco tempo atrás os pais e mães acreditavam na idéia de que a educação dos filhos poderia ser realizada mediante intuição, ou a própria vocação inerente a paternidade e maternidade. (Szymanzki, 2007).

Embora a grande maioria dos pais não confie mais nessa idéia, poucos são os pais bem orientados a respeito da melhor educação a oferecer aos seus filhos. Sem formação escolar, sem acesso a leitura e ao conhecimento, a maioria dos pais educa seus filhos: "conforme as lições da faculdade da vida", segundo relatos deles mesmos.

3- Tipo de escola.

Existe uma tendência considerável, amparada pelos resultados obtidos pelas escolas nos instrumentos de avaliação institucional, em comparar o ensino da escola pública com o das escolas privadas, apontando, infelizmente para um déficit na qualidade do ensino público em relação ao ensino privado. Para essa pesquisa, houve significância estatística $(p=0,000)$ em relação à renda familiar dos participantes e suas respostas aos construtos. Os participantes dessa pesquisa estavam assim divididos: 54,8\% deles tinham filhos estudando em escola pública ou eram profissionais da educação da escola pública e $45,2 \%$ deles tinham filhos matriculados na escola privada.

Apontando também para uma validade convergente, a variável tipo de escola apresentou significância estatística $(\mathrm{p}=0,000)$ em relação ao tipo de escola e os construtos: respeito, justiça e autonomia. Conforme já observado nas variáveis, renda familiar e formação escolar que também apresentaram diferenças significativas estatisticamente, o instrumento denotou a sua coerência, apontando a dificuldade das classes mais baixas da sociedade brasileira em educar para a autonomia.

No caso dessa variável, tipo de escola, o resultado apresentado mostrou que os pais das escolas públicas, dão respostas com média mais baixa para os construtos: respeito, justiça, autonomia, quando comparados a média das respostas dos pais de escolas privadas para os mesmos construtos. Com relação às diferenças entre as respostas dos pais de escola pública e privada para o construto obediência, não se encontrou significância estatística $(p \geq 0,005)$. 
4- Profissão dos participantes.

O resultado dessa variável é bastante importante para a temática da pesquisa. Esperavase que os profissionais da educação oferecessem respostas mais evoluídas que os participantes das demais profissões, isto porque, esperava-se que, por possuírem formação na área da educação esses pais se mostrassem melhor qualificados para a educação dos seus filhos. Porém, coerentemente com os resultados da variável anterior, o que mais uma vez implica em uma validade convergente do instrumento, houve significância estatística $(p=0,000)$ apenas em relação aos profissionais de baixa qualificação que responderam diferentemente em relação as demais profissões.

Os participantes apresentaram os seguintes percentuais para a variável profissão: $9,3 \%$ eram profissionais liberais, $19,1 \%$ eram profissionais da educação (essa alta porcentagem da amostra se refere ao fato de que, como a pesquisa foi realizada nas escolas, todos os professores, coordenadores e diretores que possuíam filhos na faixa etária da pesquisa, 12 a 20 anos, eram convidados a participar), 17,4\% eram profissionais técnicos, 17,9\% eram profissionais de baixa qualificação (por exemplo, empregada doméstica, porteiro, caseiro), e $36,3 \%$ estavam categorizados em outras profissões ${ }^{36}$.

A relação observada foi que os profissionais de baixa qualificação tendem a dar respostas com médias inferiores para os construtos - respeito, justiça e autonomia - e respostas com médias mais altas para o construto da obediência, quando comparados às respostas dadas pelos outros profissionais.

\section{5- Regiões}

Esse é o resultado mais surpreendente com relação às variáveis dependentes. Em primeiro lugar porque não foram encontradas diferenças significativas $(p \geq 0,005)$ em relação às respostas dadas pelos pais das diferentes regiões brasileiras pesquisadas. A única diferença significativa estatisticamente $(\mathrm{p}=0,000)$ observada foi com relação às respostas dadas pelos participantes da cidade de Salvador, no estado da Bahia, na região do Nordeste.

\footnotetext{
${ }^{36}$ Entende-se que essa categoria outros não foi bem organizada por essa pesquisa, pois acabou assumindo profissões bastante diversas como: comerciantes, empresários, autônomos, vendedores, e inclusive desempregados, foram computados por essa categoria.
} 
Em relação às demais respostas, os pais de Salvador apresentaram respostas com média bastante alta para os construtos da justiça, autonomia e respeito, e respostas com média baixíssima para o construto da obediência.

A questão é que a pesquisa em Salvador foi realizada em um colégio particular conceituadíssimo e centenário na cidade: portanto a maioria dos participantes tinha formação escolar com nível de pós-graduação e renda familiar alta (convergindo com as variáveis anteriores). A reunião de pais nesse colégio teve uma dinâmica extremamente diferenciada das demais observadas pela pesquisadora. Primeiramente os pais participaram da pesquisa, depois da reunião de pais, que foi conduzida pelo coordenador dos segundos anos do ensino médio. O tema da reunião foram os desafios do vestibular.

A reunião teve o esquema de uma assembléia com a participação ativa dos genitores que expuseram suas opiniões e puderam trocar pontos de vistas com os professores e outros participantes. Esses pais também demonstraram grande interesse pela pesquisa.

Obviamente esses estudos sobre as análises das tendências segundo as variáveis dependentes poderiam se desdobrar no interior das amostras com análises mais específicas sobre o comportamento de cada variável. Entretanto, discussões mais profundas não serão efetuadas nesse texto, o qual priorizou a elaboração e validação da Escala de Concepções Educativas. 


\title{
9 CONSIDERAÇÕES FINAIS
}

\begin{abstract}
Não obstante, a pessoa autônoma foi heterônoma. Logo, o olhar e o juízo alheios participaram da construção de suas representações de si. E, se ela conseguiu como o queria Sartre, fazer alguma coisa com o que haviam feito dela, é em parte porque o que fizeram dela facilitou a conquista da autonomia. E o que fizeram dela ocorreu sobretudo durante sua infância e adolescência. (La Taille, 2009, p.306).
\end{abstract}

O instrumento elaborado por essa pesquisa permitiu avaliar e responder a pergunta: Os pais e mães brasileiros tendem a formar os adolescentes para a construção da autonomia moral? Terminada a pesquisa, o que pode ser dito aos pais dos adolescentes do nosso país?

A resposta para a primeira pergunta é mais simples. Conforme os resultados discutidos pelo capítulo anterior, há um evidente desejo por parte dos pais e mães brasileiros de proporcionar aos seus filhos uma educação que viabilize a construção da autonomia moral.

Os dados revelaram a boa intenção dos pais. Todos os itens que investigavam o julgamento dos pais a respeito da educação dos seus filhos, apontaram que os genitores têm grande interesse que os seus filhos se desenvolvam plenamente, tornando-se pessoas justas, respeitosas, dignas e responsáveis, e por isso, suas representações a respeito de como deve agir um bom pai são bastante adequadas.

Por outro lado, os dados coletados também revelaram a grande dificuldade encontrada pelos pais para colocar essas boas intenções em prática. Pode-se afirmar que os pais e mães brasileiros não querem que os seus filhos adolescentes sejam jovens submissos, apáticos e incapazes de terem as suas próprias iniciativas, idéias, sentimentos e experiências. A questão é que, muitas vezes as atitudes que revelaram tomar são inconsistentes e algumas vezes contrárias aos seus objetivos.

Dessa forma, o mapeamento realizado por essa investigação a respeito das concepções educativas no tocante a relação pais e adolescentes e os construtos obediência, respeito, justiça e autonomia, demonstrou que a maior dificuldade encontrada pelos pais brasileiros para educar para a autonomia, está na transformação dos seus desejos e objetivos para com a educação dos filhos em atitudes acertadas e coerentes que, de fato, promovam oportunidades reais aos adolescentes de construção da autonomia moral.

Em outras palavras, a principal dificuldade encontrada pelos pais, diz respeito à temática das sanções, ou seja, como agir quando o filho ou filha estão seguindo por um caminho que os pais não consideram correto, ou quando o jovem deixa de cumprir uma regra, cujo princípio 
era inegociável. As respostas dos pais para questões que tratavam dessa temática demonstraram uma opção por caminhos inadequados para a construção da autonomia moral.

Sabendo que a temática das sanções implica no construto da justiça, pode-se afirmar que, conforme os resultados dessa pesquisa, o maior impasse para a participação dos pais na formação moral dos filhos adolescentes diz respeito às questões de justiça. Obviamente que, no caso desse trabalho, os construtos que construíram o estudo das concepções educativas dos pais de adolescentes não são excludentes, mas congruentes. Dessa forma, dizer que essa pesquisa indicou que o principal problema da educação moral está no fator justiça, não implica de forma alguma em afirmar que no tocante a obediência, respeito e autonomia, tudo caminha bem.

Quando uma sansão se faz necessária, isso significa que uma regra foi descumprida, e é função do adulto tomar alguma atitude para que o educando compreenda a legitimidade da regra e de algum modo restitua a autoridade dela. Quando o jovem deixa de cumprir uma regra e fica sem nenhum tipo de punição, o significado para ele é: essa regra não tem importância, não é legítima. Entretanto, conforme Piaget (1932/1994, p. 270): “existem pelo menos dois tipos extremos de regras e de autoridade: a regra devido ao respeito unilateral e a regra devido ao respeito mútuo".

Portanto, quando a regra é devida ao respeito unilateral, a sua imposição se faz por meio da obediência, que conduz a heteronomia, mas, por outro lado, quando a regra é fruto de um acordo mútuo, adquirida pelo hábito da reflexão, compreensão e escolha pautada nas relações de cooperação, garante-se a possibilidade do desenvolvimento da moral autônoma. Conforme a distinção apresentada por Piaget (1932/1994): existe a teoria do dever e da obrigação moral e a do bem ou da autonomia da consciência. A primeira fundamenta-se na autoridade, a segunda nos princípios de justiça.

Entendendo a justiça, de maneira piagetiana, como o sentimento moral responsável pelo equilíbrio das relações com os outros, não está equivocado afirmar que a relação entre pais e adolescentes não está devidamente equilibrada para conduzir à formação de pessoas autônomas.

Esse resultado é bastante preocupante: há quase oitenta anos atrás, quando Piaget (1932/1994) publicou as suas investigações sobre a moralidade infantil, também afirmou ser a questão das sanções o problema mais complexo da educação moral. Porque após tantos avanços nas teorias do desenvolvimento humano psicológico e nas teorias sobre educação, os pais e, porque não dizer também, os educadores brasileiros, se deparam com a mesma dificuldade inerente ao processo da educação moral? 
As respostas para essa pergunta são muitas, ou, na verdade, a questão pode ser respondida a partir de muitos fatores. Entretanto, esse trabalho fez a opção por refletir a respeito de três aspectos inerentes ao processo de educar os filhos, entendendo-os como imprescindíveis para a presente discussão: os desafios de educar em tempos pós-modernos, o adulto da relação, a educação e o conhecimento.

1- Os desafios de educar em tempos pós-modernos

Educar nos dias atuais tem maiores desafios porque a sociedade atravessa apresenta características que se impõem aos educadores como obstáculos ao processo educativo. Talvez a mais importante das características da sociedade atual para a problemática da formação dos adolescentes é que o mundo tem valores instáveis (tudo pode, e nada mais indigna ninguém). De acordo com La Taille (2009, p. 39): "Vivemos, por conseguinte, não em um mundo sem valores, pois a afetividade está inevitavelmente presente e atuante, mas sim em um mundo sem valores estáveis, em um mundo de valores que se equivalem e que se revezam”.

Sendo os adultos, pais e mães, os principais responsáveis pela apresentação dos filhos ao mundo regrado, essa realidade contemporânea ressoa de forma conflituosa para a educação das crianças e adolescentes do nosso tempo. O que é o certo e o que é o errado? Como se deve agir? Que tipo de pessoa eu quero ser? O que não se pode deixar de ensinar aos filhos? São perguntas difíceis de serem respondidas nos dias atuais, quando tudo se torna intercambiável. A sociedade é guiada pelo arbitrário, pelo hedonismo, pelo narcisismo, pelo consumismo, pelo descartável e pela dificuldade para atribuir sentido à vida. Conforme Costa (2004, p. 185), as pessoas da sociedade contemporânea fundamentam as suas identidades no narcisismo e no hedonismo.

Basear a identidade no narcisismo significa dizer que o sujeito é o ponto de partida e chegada do cuidado de si. [...] Família, pátria, Deus, sociedade, futuras gerações só interessam ao narcisista como instrumento de auto-realização, em geral entendida como sucesso econômico, prestígio social ou bem-estar físico e emocional. [...] Assim, o sujeito da moral hodierna teria se tornado indiferente a compromissos com os outros - faceta narcisista - e a projetos pessoais mais duradouros - faceta hedonista. (Costa, 2004, p.186)

Mas filho é um projeto pessoal duradouro. Não se pode divorciar ou desistir dos filhos. O filho é alguém que necessita de cuidados e proteção até que esteja pronto para ingressar no mundo adulto (Arendt, 1964/2005, p. 235). Uma criança não pode significar para o pai apenas auto-realização. Segundo os estudos de Nogueira (2005, p.570), algo extremamente importante para a família contemporânea diz respeito ao fato de que os filhos significam, hoje 
em dia, mais que objeto de afeto e de cuidados dos pais, chegando a ser razão de viver deles e o modo de se realizarem.

A grande maioria das pessoas que compõem essa sociedade hodierna, narcisista e hedonista, e, nesse caso, as diferenças de classes sociais parecem não ser consideráveis, têm filhos como uma condição que dá um determinado status social e um significado de autorealização. Todavia, não assumem o compromisso que os filhos representam. A busca pelo prazer a qualquer custo, torna as relações sociais frágeis e líquidas, conforme as palavras de La Taille (2009, p.63): “Queremos estar com pessoas de convívio leve e agradável, não com pessoas com as quais trilhamos longos caminhos, com as quais construímos projetos de vida, com as quais procuramos desvendar os mistérios da existência”.

O processo de educação de um filho nem sempre é leve e agradável. Todo pai e toda mãe sabem, ou deveriam saber, que a educação é um processo complexo que permeia todo o desenvolvimento da criança e do adolescente. Quando se tem um filho, é necessário que ele esteja incluso realmente no projeto de vida desse adulto que o trouxe ao mundo. $\mathrm{O}$ adulto que gera um filho se constitui autoridade para ele, até que o pequeno se transforme em adulto.

Portanto, não é de se estranhar que o lugar da autoridade nas sociedades contemporâneas tenha sido substituído pelo das celebridades e que o principal objetivo dos pais seja que os seus filhos se tornem vencedores, o que significa exatamente: ser de alguma forma um tipo de celebridade. (La Taille, 2009; Costa, 2004).

O abandono da autoridade está absolutamente atrelado à outra característica da sociedade moderna que é a clara desvalorização do passado e da tradição. Conforme as contribuições de Arendt (1964/2005, p.130) a perda da tradição, implica na perda da memória que guiou a humanidade com segurança como um fio condutor aos vastos domínios do passado. A perda da tradição não é desapego ao passado, mas significa a perda da profundidade da existência humana.

Para a autora, a autoridade está alicerçada sobre a tradição, uma vez que essa última faz o elo de ligação entre a sucessiva geração e um aspecto predeterminado do passado. E, conforme os seus estudos, o maior sintoma da crise da autoridade, é o fato dela ter atingido inclusive a criação dos filhos. Nas suas próprias palavras:

O sintoma mais significativo da crise, a indicar sua profundeza e seriedade, é ter ela se espalhado em áreas pré-políticas tais como a criação dos filhos e a educação, onde a autoridade no sentido mais lato sempre fora aceita como uma necessidade natural, requerida obviamente tanto por necessidades naturais, o desamparo da criança, como por necessidade política, a continuidade de uma civilização estabelecida que somente pode ser garantida se os que são recém- 
chegados por nascimento forem guiados através do mundo preestabelecido no qual nasceram estrangeiros. (Arendt, 1964/2005, p. 128).

Essas questões são realmente observáveis na temática da relação pais e filhos. São raríssimos os pais e mães de hoje em dia que pensam em criar os seus filhos conforme foram criados pelos seus próprios pais. Obviamente que as gerações anteriores abusaram das intervenções autoritárias e conforme os dados da presente pesquisa, o objetivo dos pais que participaram da pesquisa, não é a obediência dos filhos.

O que se observa é que os pais negam a própria autoridade, na ansiedade de não reproduzirem a educação autoritária que receberam, entretanto, contrariamente, as formas de controle dos filhos permanecem, são muitas, e tantas vezes veladas: câmeras nas escolas, os celulares com GPS, a "espiada" nos pertences do filho sem a sua autorização (conforme demonstrou essa pesquisa) e outros tantos tipos de vigilância. Dessa forma o autoritarismo não foi de maneira alguma substituído pela cooperação, mas por estratégias que passam pela ausência de respeito, pelo respeito unilateral e até mesmo pela própria negligência.

Outras características da sociedade contemporânea que dificultam a relação pais e filhos são: a ditadura da velocidade - "tudo se sucede em uma velocidade estonteante, o que vale hoje talvez nada valha amanhã” (La Taille, 2009, p. 37) - e o consumismo típico de uma sociedade na qual os bens não se herdam e nem são adquiridos, mas são necessariamente consumidos.

Portanto, os pais que trabalham de forma alucinada para "garantir aos seus filhos aquilo que nunca tiveram”, não têm tempo para eles. Sentem-se responsáveis pela felicidade dos filhos e não pela formação do seu caráter, o que implica em trabalhar ainda mais para jamais frustrar os desejos dos filhos, porque eles "merecem o que de melhor o mundo possa lhes oferecer" e não podem se sentir inferiores diante dos colegas. Afinal o objetivo é formar "vencedores", porque o mundo não tem lugar para perdedores, representados pelos pobres, pelas minorias, pelos que não têm os carros importados, entre outros "valores".

Educar é, portanto, cada vez mais um processo desafiador. Mas o desafio dessa sociedade deve ser considerado motivo para o investimento na educação: "Porém é nas ambigüidades e paradoxos que ela deve intervir. É tomando lugar nos jogos de forças contraditórias que ela pode ter sucesso". (La Taille, 2009, p.76). A dificuldade deve ser utilizada como justificativa principal para a transformação dessa realidade. Conforme as palavras simples e sábias de Sayão e Aquino (2006, .43): “A família é responsável por transformar um filhote em um ser humano". Educar é humanizar. 
2- O adulto da relação

A adolescência como fase de tempestade e tormenta foi uma questão extremamente discutida por esse texto. A maioria das pesquisas apresentadas no segundo e no terceiro capítulos considera a adolescência como mais uma fase do desenvolvimento humano. Entretanto, conforme Steinberg (2001), a idéia da adolescência como uma fase de desobediência e intenso conflito na relação entre pais e filhos permanece presente no imaginário das pessoas, especialmente, dos pais e mães de adolescentes.

Ainda que, os dados de Smetana (2006) também afirmem que apenas 5\% a $15 \%$ dos adolescentes apresentam grandes manifestações de turbulência emocional e dificuldades excessivas de convívio com os pais, a grande maioria dos genitores admite que teme não ser capaz de cumprir com eficiência o papel de pais e mães na adolescência (conforme dados colhidos informalmente pela pesquisadora, nos momentos de formação que aconteceram após as coletas de dados).

Parece que a grande dificuldade enfrentada pelos pais de filhos na fase da adolescência, encontra-se em lidar com a angústia e com a perda do filho. Obviamente essa perda está atrelada a outro tema muito discutido pelas pesquisas a respeito do desenvolvimento adolescente: a separação dos filhos no final desse processo. Esse momento costuma ser ambíguo e angustiante para os pais, pois implica no conflito de deixar de ser necessário e ao mesmo tempo serem apoio e suporte nessa fase de transição do filho. (Berthoud, 2003, p.142).

A adolescência é ambígua e dolorida porque o filho deixa de ser criança para nunca mais voltar a sê-lo, o que implica para os pais em uma re-significação do modo de ser adultos na relação, sendo que esse caminho sem volta deverá levar o adolescente a assumir o papel de adulto. Dessa forma, além da perda do filho criança, os desafios que se apresentam aos pais são os de: "exercer ou não a autoridade, quais os limites no relacionamento pais e adolescentes, o questionamento se a educação dada foi eficiente e a angústia sobre como o filho vai enfrentar o mundo". (Berthoud, 2003, p.146).

Portanto, é bastante difícil ser o adulto da relação nessa fase. Surge a "sensação de missão cumprida" que pode levar os pais a abandonarem os filhos adolescentes a sua própria sorte. Esse é um erro muito grave, pois, embora nessa fase a independência do jovem se amplie consideravelmente em relação à infância, pela própria conquista de um raciocínio abstrato que lhe permite elaborar as suas próprias hipóteses sobre o mundo (Inhelder e Piaget, 1970/1976), o adolescente ainda não é um adulto e, como tal, necessita do apoio, do suporte, 
do modelo, das provisões e reserva de valores dos pais, que são os verdadeiros adultos da relação.

O objetivo da adolescência é tornar-se um adulto. Mas, o adulto da relação são os pais. Estes sim deveriam ser e agir como sujeitos autônomos.

Ser autônomo, sobretudo no que tange a ideais ideológicos, morais e éticos, é característica de pessoas mais velhas, que conseguiram parte de suas dependências heterônomas. E, se elas, hoje, conseguem eleger valores, conservá-los a despeito da desvalorização constante que eles sofrem, é que, em um momento anterior de suas vidas, tiveram oportunidade de viver num contexto mais estável, no qual havia vetores que apontavam para certas opções de vida, e não outras”. (La Taille, 2009, p.46)

Desse modo, seja porque, realmente, a maioria das pesquisas que investigaram o juízo moral dos adultos, entre elas especialmente os estudos de Kohlberg, demonstraram que a maior parte dos adultos permanece heterônoma moralmente (Biaggio, 2006, p.24); ou seja devido às considerações citadas no item anterior a respeito da instabilidade dos valores na sociedade contemporânea, a questão é que, as famílias não têm mais representado para os seus filhos um contexto estável, fonte de boas regras, boas pessoas (que sejam cumpridoras dessas regras) e reserva de valores morais.

Ser o adulto da relação significa ser o autônomo da relação. Significa "segurar o tranco", significa ser suporte, ser presente, ser amoroso, ser provedor do diálogo, ser equilibrado e justo nas relações com o adolescente. "Ter domínio sobre si é ser autônomo". (La Taille, 2009, p.266).

\section{3- A educação e conhecimento}

Pode-se afirmar com certeza que, os pais que participaram dessa pesquisa constituíram uma amostra especial de pais e mães. Mas especiais em quê e porquê? Porque os participantes da pesquisa foram pais que compareceram aos chamados da escola, para tratar de assuntos relacionados aos seus filhos. Essa postura é indicativa de interesse, responsabilidade e compromisso com o papel de educador e formador dos jovens, seus filhos. Essa postura é também indicativa de quem se dispõe a ouvir aos professores que são especialistas em educação.

Por isso, essa afirmação de que a amostra de participantes da presente pesquisa não é composta por quaisquer pais, pois, esses são pais preocupados com a necessidade de conhecer, de saber a respeito, no mínimo, do desempenho escolar dos seus filhos. Desse modo, pais que se dirigiram a escola dos filhos, pais que se dispuseram a permanecer após a 
participação da pesquisa partilhando suas experiências e ouvindo as reflexões da pesquisadora.

Infelizmente, pouquíssimas são as opções que os pais têm de refletirem a respeito da educação dos seus filhos. Livros de auto-ajuda são muitos no mercado, entretanto, essa pesquisa demonstrou que, dos pais entrevistados, mais de 35\% têm renda familiar inferior a dois salários mínimos e formação escolar mínima. Para esses pais os livros são praticamente inacessíveis.

Para aqueles com melhores condições financeiras e maior formação escolar, a dificuldade está no encontro com nomes reconhecidos no campo dos livros que se destinam à orientação familiar e que propõem aos pais sugestões como a seguinte:

Depois que pai ou mãe ensinaram uma regra ao filho, pergunte se ele a entendeu. Se entendeu, peça a ele que lhe explique com as palavras dele. Esta é uma maneira de transformar uma informação em conhecimento. Um conhecimento adquirido requer a prática para a sua consolidação.

$\mathrm{O}$ filho tem que praticar o que deve fazer, e os pais devem exigir que o faça e não devem explicar outra vez a mesma regra. O filho não pode fazer outra atividade comer, beber, dormir, fazer xixi etc. - enquanto não fizer o que precisa, mesmo que se tenha de usar de força física para colocá-lo de volta no "local de trabalho". (Tiba, 2009, 51).

Já se comentou no primeiro item desse capítulo da grande dificuldade dos pais que, devido à negação da tradição e ao não desejo de educar os seus filhos conforme foram educados pelos seus pais, não têm referenciais para orientar a educação dos seus filhos. Imagine-se então que o pai de um adolescente venha a adquirir esse tipo de informação.

Conforme todo o referencial teórico que fundamentou essa pesquisa, certamente, a intervenção apresentada na citação anterior não conduz à formação de pessoas autônomas. A citação fala sobre utilizar a punição física se necessário. Certamente o autor dessas palavras acima citadas atribuiria a nota sete (concordo plenamente) para o construto: "um pai pode punir fisicamente o seu filho quando ele faz algo muito errado".

A punição física é proibida por lei no nosso país, segundo o artigo $3^{\circ}$ do ECA (Estatuto da criança e adolescente). Trata-se da mais representativa das sanções expiatórias. Deixar sem comer, sem dormir, sem fazer xixi, também são exemplos nítidos desse mesmo tipo de sanção e que, ainda gerarão a humilhação. Além disso, comer, dormir e fazer xixi, são regras que pertencem ao tema da saúde e, portanto, inegociáveis. Usar essas atividades como punição significa negar princípios de saúde. 
Por outro lado, será realmente que, perguntar a uma criança se ela entendeu a regra, e fazê-la repetir a regra com suas próprias palavras é suficiente para "transformar informação em conhecimento"? A primeira grande questão é: o autor se dirige a qual faixa etária? Porque se um pai falar assim com um bebê, o mesmo sequer compreenderá a pergunta; se falar assim com um menino de 5 anos, o mesmo repetirá provavelmente "feito um papagaio" e a regra continuará externa e não realizável; e se finalmente, no caso, o interlocutor for um adolescente, provavelmente, a reação dele será dizer ao pai algum tipo de grosseria tão tipicamente utilizada pelos jovens, como por exemplo, "pai, sai dessa".

Os pais necessitam conhecer as características afetivas, cognitivas, sociais e morais de cada fase do desenvolvimento dos seus filhos. As intervenções junto ao adolescente não são as mesmas que para o pré-escolar. Por outro lado, a legitimação das regras pelas crianças é fruto de um processo demorado de interiorização das mesmas, na medida em que, as suas razões são explicadas para a criança e a regra é constantemente reafirmada ao longo do desenvolvimento infantil, como um princípio que se origina num valor que o pai quer ensinar ao filho. (Piaget, 1932, 1948, 1965; La Taille, 1998, 2005, 2006, 2009; De Vries e Zan, 1998).

"Devemos ter claro que a moral é um objeto de conhecimento" (La Taille, 2009, p225), portanto, os pais para educarem bem moralmente, necessitam ter clareza a respeito de quais valores querem que os seus filhos construam e, mais que isso, quais são as boas intervenções, ou, conforme a teoria piagetiana, como estabelecer com os filhos relações de cooperação que, de fato, lhes permitam tomar consciência das regras, refletir sobre elas e incorporar os seus princípios como valores que os constituirão como pessoa.

Obviamente que não será mandando a criança repetir a regra e impedindo-a de "sair do local de trabalho", conforme sugere Tiba (2009) em seu texto, que o pai auxiliará os filhos a se comportarem adequadamente, quanto mais, lhes oferecerão verdadeiras e boas oportunidades para construírem valores desejáveis.

Logo, a dificuldade dos pais em educarem os seus filhos nos tempos atuais, perpassa por esses três aspectos: os desafios contemporâneos, a dificuldade de ser o adulto da relação e a falta de conhecimento.

Mas, onde os pais podem encontrar ajuda para superarem as suas dificuldades em relação à educação dos seus filhos?

Piaget (1948/2000, p. 50) responde a questão: “se toda pessoa tem direito à educação, é evidente que os pais também possuem o direito de serem senão educados, ao menos informados e mesmo formados no tocante à melhor educação a ser proporcionada aos seus 
filhos". E, quem são os profissionais que podem oferecer esse tipo de informação e formação aos pais? Aqueles que são especialistas e profissionais da educação, ou seja, os professores.

A resposta a essa questão é bastante explícita no plano verbal e teórico, entretanto, bastante complexa no plano concreto. As pesquisas revelam assimetria, complexidade e até mesmo a relação conflituosa entre a família e escola, que muitas vezes se tratam como adversárias. (Nogueira, Romanelli e Zago, 2000, p.9). Porém, quando se pensa na educação enquanto um processo de humanização cujo objetivo maior é formar cidadãos autônomos, as duas instituições, família e escola são requisitadas para desempenhar o seu papel:

Pessoalmente, creio que os conhecimentos de psicologia de que hoje dispomos mostram bem que, em se tratando de educação moral ou não, tanto a família quanto a escola desempenham papéis fundamentais, tanto cognitivos como afetivos e sociais, sendo, portanto, imperativo que haja complementariedade, cooperação e mútua ajuda entre as duas instituições para que a parceria escola/família se torne uma realidade. (La Taille, 2009b, p. 11).

A importância de tratar do tema da relação escola família nesse texto se explicita por quatro fatores: o primeiro, por se concordar com o argumento descrito por La Taille (2009) de que há a necessidade de uma relação de parceria e cooperação entre escola e família em prol da formação das crianças e adolescentes; o segundo motivo é justificado pela própria dinâmica da coleta de dados dessa pesquisa, realizada no ambiente escolar; a terceira justificativa se remete à necessidade de ilustrar as diferentes formas observadas durante a pesquisa para trazer a família para a escola, e as imbricações entre a escolha da escola, a formação do aluno e a formação da própria família; e, por último, o quarto motivo, e o mais importante, diz respeito ao fato de se acreditar que a escola pode verdadeiramente auxiliar na formação da família, dando-lhe concretas oportunidades de ampliarem o seu conhecimento a respeito do desenvolvimento dos seus filhos, desde que os professores estejam também eles, verdadeiramente bem formados e preparados para isso.

A opção pela discussão da temática da relação escola e família inicia-se, portanto, a partir do apontamento das observações realizadas pela pesquisadora durante o processo de coleta de dados, entendendo-os como dados significativos para a melhor compreensão dessa dinâmica entre as duas instituições.

$\mathrm{O}$ acesso às escolas públicas foi mais difícil e demorado do que o acesso às escolas privadas, inclusive a pesquisadora realizou diferentes formas de contato com escolas públicas da cidade de Palmas (Tocantins) e Brasília (Distrito Federal), buscando espaço para a pesquisa, durante o período de um ano, sem sucesso. O mesmo aconteceu em uma escola 
publica no interior de São Paulo, que justificou para a pesquisadora que não poderia perder tempo da reunião de pais com pesquisas e palestras.

No final do processo de resposta ao instrumento em determinada escola pública, uma mãe veio se justificar com a pesquisadora a respeito da sua impossibilidade de participar do momento de formação, sempre proporcionado após a coleta de dados. Quando a pesquisadora afirmou que não tinha problema e agradeceu a participação da mãe na pesquisa, a mesma perguntou à pesquisadora se o seu filho poderia entrar na escola no dia seguinte. Como a pesquisadora demonstrasse surpresa diante da pergunta, a mãe explicou que, quando os pais não vêm à reunião é regra da escola suspender os respectivos filhos-alunos da aula do dia seguinte.

Essas duas observações relatam a grande dificuldade que permeia a relação escola e família: no primeiro caso, a questão da informação, formação e conhecimento não é considerada importante pela equipe gestora da escola, e no segundo caso, a participação dos pais em um momento de formação está atrelada à possibilidade de deixar o filho sem aula, sendo o adolescente o punido pelo não comparecimento dos mesmos.

A escola é um espaço privilegiado para o desenvolvimento moral. Piaget (1930/1996) afirma a importância do papel da escola, como espaço para as relações de cooperação entre pares, para o exercício do self-government, e, portanto, espaço propício para a construção da autonomia intelectual e moral. Para La Taille (2009, p.80) "Escola é uma verdadeira usina de sentidos, sentidos de vida (ética) e de convivência (moral), e não há outra instituição social de que se possa dizer o mesmo". Entretanto quando a escola reproduz nas suas relações as estratégias de coação tão utilizadas pela família, inclusive aplicando-as contra a família, as dificuldades para formar para autonomia são ampliadas.

Outra observação extremamente pertinente para a temática da relação escola e família e ainda pertencente ao âmbito das observações acerca do processo de coleta de dados, diz respeito ao interesse, apreciação e boa vontade, demonstrados por todos os participantes, tanto no processo de participação da pesquisa, quanto do processo de formação posterior.

Contrariamente a essa realidade demonstrada pelos pais que participaram dessa pesquisa, demonstrando interesse na informação a respeito da educação dos filhos, as escolas costumam acusar os pais de serem ausentes do processo educativo dos filhos e totalmente negligentes com o acompanhamento do seu desempenho escolar. É bastante comum que a instituição escola classifique, julgue e avalie as famílias: 
Além dos pais que são 'presentes' ou 'ausentes' na vida dos filhos, uma outra terminologia aparentemente mais sofisticada passa a ser usada. Agora, há uma grande variedade de diagnósticos: famílias 'desiquilibradas', 'desorganizadas', 'neuróticas', 'descentradas', 'instáveis', 'em dissolução', etc. (Sayão e Aquino, 2006, p. 101)

Certamente esse não é papel da escola: reprovar os pais. Tampouco reprová-los fundamentando-se em pré-conceitos a respeito da organização familiar. Conforme os resultados dessa pesquisa, a variável estrutura familiar (solteiro, casado, etc) não apresentou significância estatística em relação às respostas dos pais para a forma de educar aos seus filhos. Por outro lado, o trabalho de coleta de dados dessa pesquisa comprovou, ao menos nessa amostra (que pode ser considerada especial, conforme comentário das linhas anteriores), que há um grande interesse por parte dos pais em serem informados e formados a respeito da educação dos seus filhos.

Quanto às pesquisas que se debruçam sobre o estudo da relação escola e família, elas se mostram unânimes a respeito da necessidade da parceria entre as duas instituições, enquanto aspecto positivo na formação do aluno. (Paro, 2000; Sá, 2001; Polônia \& Dessen, 2005; Szymanski, 2007; Caetano, 2009). Há ainda as pesquisas, como é o caso da pesquisa de Szymanski (2007), que afirmam a necessidade do exercício de práticas educativas familiares numa perspectiva de formação, compreendendo que a troca e o diálogo entre pais, pesquisadores, educadores e outros profissionais podem ser de grande valia para o desenvolvimento da área educacional da família.

Logo, uma vez que a própria comunidade científica de pesquisadores é unânime quanto à relevância da contribuição da família, a escola que conta com os especialistas em educação, profissionais preparados e remunerados para a educação formal das crianças, necessita refletir sobre algumas questões: a participação da família é importante, mas a não participação da mesma, não pode ser justificativa para o fracasso escolar, assim como, a escola pode e deve realizar um trabalho de construção de parceria com a família, mas isso não implica em transformar imediatamente a família. Esse trabalho de transformação social é papel sim da escola, mas a longo prazo, e acontece quando a escola verdadeiramente assume o seu papel. (Caetano, 2009, p.53).

Ainda é importante dizer que, a parceria entre escola e família, uma vez constituída, servirá para os educandos também, como modelo de convivência cooperativa. "Logo para além de lições de moral que explicam e cantam as virtudes da justiça, da generosidade, da dignidade, da liberdade, por melhor que sejam, deve imperativamente haver uma 'vida social' na qual tais virtudes regulem as relações interpessoais". (La Taille, 2009, p. 257). Em tempos 
de crise na educação, crise de valores, crise da autoridade, crise econômica e social, e tantas outras dificuldades que os recém-chegados ao mundo (os filhos e os alunos) enfrentarão, a qualidade das relações é condição necessária ao desenvolvimento moral.

Então, a parceria na relação escola família é uma condição importante para a formação dos adolescentes, sendo que, nessa empreitada, a escola deveria estar melhor preparada para acolher, formar e cooperar com as famílias. Infelizmente, os resultados da presente pesquisa, demonstraram que os professores não parecem estar preparados para esse processo. Consistente com os estudos de Paro (2000) a respeito da contribuição dos pais para a qualidade do ensino, que também apontou para o reconhecimento por parte dos professores de que não se sentem devidamente formados e preparados para a construção da parceria com a família; os resultados da presente pesquisa demonstraram que não houve respostas diferentes dos profissionais da educação em relação aos construtos estudados por essa pesquisa e os demais profissionais avaliados.

Logo, a problemática da formação dos professores se apresenta como uma condição necessária para a construção da autonomia moral dos jovens, tanto para a sua atuação como educadores formais nas escolas, quanto para que possam se aliar à família nessa empreitada de formar pessoas de bem.

Resta ainda talvez a mais importante das considerações: terminada a pesquisa, o que pode ser dito aos pais dos adolescentes do nosso país? Diferentemente da primeira pergunta que esse capítulo respondeu, a resposta a essa última é bastante complexa, e, verdadeiramente, outros tantos capítulos precisariam ser escritos com o propósito de oferecer orientações pautadas no rigor cientifico do resultado de pesquisas sobre o desenvolvimento humano, e, especificadamente, o desenvolvimento moral do adolescente.

Mas, ainda que correndo o risco de não fazer jus à responsabilidade da discussão, seguem algumas ponderações ou orientações julgadas essenciais à formação dos pais de adolescentes que participaram dessa pesquisa, bem como a todos os pais de adolescentes e crianças, que, na medida de suas possibilidades concretas, oferecem a seus filhos o seu melhor:

1- Sobre a adolescência

Entende-se que os pais de adolescentes necessitariam conhecer um pouco mais sobre as características peculiares dessa fase, como condição para não exigirem do adolescente uma 
maturidade que eles não têm, bem como para não negligenciarem algumas possibilidades ao mesmo, o que seria prejudicial à sua formação.

Esse é o caso, por exemplo do raciocínio abstrato do adolescente. Poucos pais sabem que nessa fase o adolescente conquista uma ferramenta essencial ao seu desenvolvimento cognitivo que são as operações formais que permitem ao jovem reconhecer todos os aspectos de uma idéia, incluindo as proposições contrárias ao fato. $\mathrm{O}$ adolescente é capaz de pensar o seu próprio pensamento. (Inhelder e Piaget, 1970/1976). Então, no início da adolescência isso faz dele um idealizador, capaz de resolver todas as crises mundiais com seus pensamentos, por outro lado, é incapaz de solucionar problemas simples da vida cotidiana.

Acontece que essa nova ferramenta, o raciocínio lógico formal, é para ele, uma possibilidade tão nova e extraordinária que simplesmente o destaca do mundo real. Assim, o adolescente se transforma em um teórico, um pensador, que, sendo dessa forma está sempre contradizendo a realidade, demonstrando a sua capacidade argumentativa, propondo suas hipóteses e buscando uma nova perspectiva para a situação. Entretanto, o seu tênis permanece imundo, seu cabelo está embaraçado, e ele acredita que escovar os dentes é perda de tempo.

Nesse processo de construção de sua personalidade, típico da fase da adolescência, o jovem necessita pensar diferentemente dos pais. Ter as suas próprias idéias é sinônimo, nessa fase, de negar as idéias dos pais. Um comportamento que enlouquece os genitores, mas absolutamente normal e saudável para o jovem que empreende o processo de construção da sua identidade. Assim, ele revela grande interesse em tomar decisões sem qualquer influência dos seus pais. Especialmente aquelas decisões que ele compreende como pertencentes ao domínio pessoal, como usar ou não pircings, pentear ou não os cabelos, arrumar ou não o quarto, escolher os amigos, início da vida sexual. (Nucci, 1981, 2005).

A ampliação da convivência social dada pela maior independência, garantida pela idade, parece ser outro grande problema para os pais. Entretanto, trata-se de uma conquista essencial para o jovem que terá a possibilidade de contrapor as suas idéias com as dos amigos, e a partir desse convívio, descobrir que as suas teorias não são as únicas e talvez nem tampouco as melhores. A convivência com os pares produz a descentração, a tomada de consciência e o esforço para situar o seu “eu” no conjunto de outras perspectivas. (Xypaz, 1997).

A adolescência é a fase em que o jovem necessita construir um plano de vida. Isso significa desejar integrar o mundo adulto como um realizador, ou seja, considerando-se como um igual aos adultos, o jovem deve inserir-se no mundo do trabalho trazendo consigo os seus sentimentos idealizados, agora transformados em planos para a transformação da sociedade. (Inhelder e Piaget, 1970/1976). 
Entretanto, cada vez mais esse processo deixa de acontecer na sociedade contemporânea. Os jovens demoram-se mais para deixar a casa dos pais e muitos deles permanecem junto com os seus próprios filhos sustentados "eternamente" pelos pais. Talvez as próprias características da sociedade contemporânea, expostas no início desse capítulo e no segundo capítulo desse texto, possam explicar ou justificar a dificuldade encontrada pelos jovens desse tempo para deixar a adolescência.

É papel dos pais: deixá-los crescer. O que deve significar ter a sobriedade de permitir que arquem com as consequiências dos próprios atos, que saibam diferenciar entre o controle do comportamento (ainda necessário na fase da adolescência) e o controle psicológico (que humilha, constrange e impede a autonomia) que não permite crescer. Que os pais sejam os primeiros incentivadores e facilitadores da construção por parte do jovem de um conjunto de valores hierarquizados, do qual façam parte valores universais como, justiça, dignidade, generosidade e respeito, para que tais valores possam responder ao tipo de pessoa que esse jovem será e o tipo de vida deseja levar.

\section{2- As sanções por reciprocidade}

Para cumprir esse papel de facilitadores da construção da autonomia, e, portanto, modelos de valores desejáveis, os pais devem refletir sobre a temática da sanção. A escolha de uma sansão foi a principal questão apontada pelos resultados dessa pesquisa, como dificuldade dos pais para educar moralmente. Ser cooperativo implica em respeito mútuo que orienta o uso de sanções por reciprocidade.

Certamente, a punição física, a ameaça, o reforço e a recompensa são exemplos de castigos exploratórios cujo principal argumento é fazer sofrer para aprender e relacionar a punição infligida com o "tamanho" da falha cometida. Por isso que os pais afirmaram que: "quando os filhos fazem algo muito errado, os pais podem puni-lo fisicamente", e que "é justo retirar algo que o filho gosta muito, quando ele não cumpre uma determinada regra”.

Entretanto esses tipos de punições não permitem ao punido pensar nas consequiências dos seus atos, reconhecer a autoridade e pertinência da regra transgredida, compreender o vínculo social que justifica a natureza e a propriedade da regra, e especialmente, desejar por si mesmo buscar uma solução para a situação problema, e, principalmente, desejar a restauração da regra.

Para que se possa compreender a diferença entre a sanção dita expiatória e aquela por reciprocidade, que se sustenta nos princípios descritos no parágrafo anterior, apresentam-se as 
idéias de Piaget (1965/1973, p. 224), ao estabelecer as relações entre as normas morais e jurídicas:

Em suma, a fronteira do domínio moral e do domínio jurídico, logo da pessoa da função e do serviço, deveria ser procurada no caráter não substituível ou substituível do indivíduo tomado como termo da relação. Isto significaria que uma personalidade jurídica designa sempre um x que poderia ser substituído por um y, enquanto moralmente as pessoas $x$ e $y$ permanecem irredutíveis. Compreenderíamos assim por que o direito é indefinidamente codificável, enquanto o princípio de uma moral tal como o amor ao próximo não poderia prever a multiplicidade de suas aplicações. (Piaget, 1965/1973, p. 224)

Uma vez que os pais buscam com as suas intervenções a construção de um conjunto de valores hierarquizados, ou seja, o cumprimento e a legitimação das regras por parte dos filhos sejam sustentados pelos princípios que explicam o porquê das regras, sendo esses princípios originários de valores desejados e universais, as sanções expiatórias não são significativas e pertinentes a esse propósito, porque, implicam no "cumprimento de uma pena", arbitrariamente definida pelo adulto, que pode ser qualquer adulto, qualquer autoridade com poder suficiente para punir.

Por outro lado, as sanções por reciprocidade apelam pela coerência interna das condutas, sendo que as normas morais que um indivíduo adota em relação a outro não podem ser contraditórias com as que ele aplica a um terceiro, nem em relação às que ele desejaria que fossem observadas em relação a ele mesmo. Assim, o pai deveria agir com o filho, da mesma maneira que gostaria que agissem em relação a ele, ou seja, a relação é de troca de pontos de vista, de compreensão mútua, fundamentada em normas que são morais por que dizem respeito às relações pessoais de reciprocidade. Portanto: "o direito constituiria o conjunto das relações normativas transpessoais da sociedade, enquanto a moral seria o conjunto das relações normativas pessoais”. (Piaget, 1965/1973, p.227).

Pensando nesse ponto de vista da moral como conjunto das relações normativas pessoais, portanto não-substituível, a punição: "toda a vez que um filho fizer algo de errado deve-se tirar algo que ele gosta", foge completamente das relações próprias da norma moral, e aproxima-se do direito jurídico, de que esse ou aquele adulto pode fazer sofrer a um determinado jovem a pena de não ter o direito à televisão porque ele bateu no seu irmãozinho, sendo a que a mesma estratégia por ser utilizada em outra casa, porque o adolescente não cumpriu o horário do jantar. Em outro lar, outro jovem pode levar uma grande surra por ter riscado o carro do pai, afinal, quando o filho faz algo muito errado é justo puni-lo fisicamente. 
O que é mais errado? O direito à propriedade alheia no caso do prejuízo ao carro do pai, ou a integridade física do irmão caçula?

O questionamento conduz a reflexão. Quando as regras trabalhadas por uma família não são consideradas no âmbito das normas morais, isto é, não dizem respeito às relações pessoais, à construção de um sistema de valores únicos insubstituíveis, universais e recíprocos, esse tipo de sanção pode ser suficiente para o culpado pagar por sua falta. Uma vez cumprida a pena, ele se sentirá livre para "novos crimes".

Mas, se o desejo é a legitimação de normas morais, a relação entre o ato a ser corrigido e a sua correção precisa ter uma relação direta, lógica, insubstituível e recíproca. Portanto, quando, por exemplo, um objeto é estragado, como no caso do risco no carro, a sanção por reciprocidade implica na restauração desse objeto, o que significa por exemplo usar a mesada para pagar o conserto do carro.

Somente a vivência de intervenções como essa, pode levar a criança ou o adolescente, ao longo do seu desenvolvimento cognitivo, afetivo, social e moral, a um processo de interiorização das regras, compreendidas como princípios justos que equilibram as relações com as pessoas. Quando os adultos desconhecem esse processo, interferem de modo contrário, reforçando a heteronomia, e, muitas vezes, o que pode ser pior, permitindo ao jovem a permanência na anomia.

O desenvolvimento moral para Jean Piaget é fruto de um processo de construção do sujeito, nos quais estruturas cognitivas e regulações afetivas se desenvolvem paralelamente de modo a promoverem a construção dos afetos normativos (Piaget, 1954/1994, p. 201), e depois, da conservação desses sentimentos, a elaboração da hierarquia de valores, que permitirá ao jovem a construção de um plano de vida, que nas palavras do autor "é de outro lado, uma afirmação de autonomia, e a autonomia moral enfim inteiramente conquistada pelo adolescente, que se considera igual aos adultos. (Inhelder e Piaget, 1970/1976, p. 260).

A família possui uma influência considerável em relação a essa construção do plano de vida do jovem, como pessoa autônoma, conforme os dados dessa pesquisa demonstraram. A compreensão de que os adultos são a grande referência para os mais jovens, de modo a auxiliá-los a fazer diferença em nossa sociedade é ao mesmo tempo uma verdade que incute esperança e desafio.

Os educadores, sejam pais ou professores, quando conscientes do seu papel na formação de seus filhos e alunos, podem cumprir verdadeiramente a sua função, de proteger os recémchegados do mundo e ao mesmo tempo oferecer ao mundo toda a possibilidade de 
transformação que ele tanto necessita, na pessoa dos novos adultos, que quando bem formados, poderão construir uma sociedade mais justa, mais digna e mais solidária.

Conforme as palavras de Turiel (2005, p.79), “entender a influência da família no desenvolvimento da criança e do adolescente é tarefa difícil e complexa". A pesquisa que se apresentou buscou trazer a sua colaboração para a temática da influência das relações parentais. Muitos novos estudos se mostraram necessários, como por exemplo, a realização de novas pesquisas utilizando a Escala de Concepções Educativas, elaborada por esse trabalho; a ampliação das investigações a respeito das variáveis dependentes que se mostraram significativas no processo da educação moral dos adolescentes; a necessidade de retomar os estudos a respeito da autonomia moral (enquanto a construção de um conjunto de valores hierarquizados que nortearão o plano de vida da pessoa); e a continuidade do investimento em pesquisas que, como essa, busquem compreender as influências do contexto familiar no desenvolvimento moral.

Porém o maior desejo e necessidade que se observa a partir desse trabalho com os pais, mães e educadores brasileiros, é realmente, que os resultados dessa pesquisa possam saltar da prateleira da biblioteca e possam alcançar os ouvidos, aos olhos, a mente e o coração de toda essa comunidade educativa, de modo que, um verdadeiro e piagetiano processo de tomada de consciência e cooperação aconteça. 


\section{REFERÊNCIAS BIBLIOGRÁFICAS}

Alves, R. (1999). E aí? Carta aos adolescentes e aos seus pais. São Paulo: Papirus.

Anastasi, A. (1986). Evolving concepts of test validation. Annual Review Psychology, 37, 115 .

Arendt, H. (1958/2007). Entre o passado e o futuro. M. W Barbosa, Trad. São Paulo: Perspectiva.

Arendt, H. (1954/2005). A condição humana. R. Raposo, Trad. Rio de Janeiro: Forense Universitária.

Ariès, P. (1973/2006). História Social da Criança e da Família. D. Flaksman, Trad. (2a ed.) Rio de Janeiro: LTC.

Battro, A. M. (1978). Dicionário Terminológico de Jean Piaget. São Paulo: Pioneira.

Baumrind, D. (1966). Effects of Authoractive Parental Control on Child Behavior. Child Development, 37, 887-907.

Berthoud, C. M. E. (2003). Re-significando a parentalidade: os desafios de ser pais na atualidade. Taubaté: Cabral Editora Universitária.

Biaggio, A. (2006). Lawrence Kohlberg: ética e educação moral. (2a ed.). São Paulo: Moderna.

Bloss, P. (1979/1996). Transição adolescente. M. R. Hofmeister, Trad. Porto Alegre: Artes Médicas.

Bom Tempo, M. S. (2005). Análise dos fatores de influência na escolha pelo curso de graduação em administração: um estudo sobre as relações e causalidade através da modelagem de equações estruturais. Dissertação de mestrado, Administração de empresas, UNIFECAP, São Paulo.

Brett, L., Coy, K. C. \& Andrew Collins, W. (1998). Reconsidering Changes in Parent-Child Conflict across Adolescence: A Meta-Analysis. Child Development, 69 (3), 817-832. 
Caetano, L. M. (2008). O conceito de obediência na relação pais e filhos. São Paulo: Paulinas.

Caetano, L. M. (2009). Dinâmicas para reunião de pais: construindo a parceria na relação escola e família. São Paulo: Paulinas.

Camino, C., Camino, L., Moraes, R. (2003). Moralização e Socialização: Estudos Empíricos sobre Práticas Maternas de Controle Social e o Julgamento Moral. Psicologia Reflexão e Crítica, 16 (1), 41-61.

Carvalho, M. C. N., Gomide, P. I. C. (2005). Práticas educativas parentais em famílias de adolescentes em confronto com a lei. Estudos de Psicologia, 22(3), 263-275.

Ceconello, A. M., De Antoni, C., Koller, S. H. (2003). Práticas Educativas, Estilos Parentais e Abuso Físico. Psicologia em estudo, 8, 45-54.

Cortella, M. S. \& La Taille, Y. (2005). Nos labirintos da moral. São Paulo: Papirus.

Costa, F. T., Teixeira, M. A. P., \& Gomes, W. (2000). Responsividade e exigência: Duas Escalas para Avaliar Estilos Parentais. Psicologia: Reflexão e Crítica, 13(3), 1-10.

Costa, J. F. (2004). O vestígio e a aura: corpo e consumismo na moral do espetáculo. Rio de Janeiro: Garamond.

Dancey, C. P., Reidy, J. (2006). Estatística sem matemática para psicologia. L. Viali, Trad. Porto Alegre: Artmed.

Darling, N., Steinberg, L. (1993). Parent Style as Context: Na Integrative Model. Psychological Bulletin, 113(3), 487-496.

De Souza, M. T. C. C. (2000). O adolescente e os mecanismos de defesa. In F. F. Sisto, G. de C. Oliveira, L. D. T. Fini (Orgs.), Leituras de Psicologia para a Formação de Professores. (pp. 35-43). Petrópolis, RJ: Vozes.

De Souza, M. T. C. C. (2002). As noções de sujeito e objeto na Teoria de Jean Piaget. In L. M. Simão.(Org.). Noção de Objeto, concepção de sujeito: Freud, Piaget e Boech. (pp. 53-60) .São Paulo: Casa do Psicólogo. 
De Souza, M. T. C. C. (2002). Cultura, cognição e afetividade: Inter-relações em diferentes perspectivas. A interação social e os objetos "afetivos" na perspectiva piagetiana de construção de conhecimento. In S.A.S. Leite. (Org.). Cultura, cognição e afetividade: a sociedade em movimento. (pp. 27-38). São Paulo: Casa do Psicólogo.

De Souza, M. T. C. C. (2003). O desenvolvimento afetivo segundo Jean Piaget. In V. A. Arantes. (Org.). Afetividade na escola: alternativas teóricas e práticas. (pp. 53-70). São Paulo: Summus.

De Souza, M. T. C. C. (2004). A concepção de construção na epistemologia genética de Piaget. In. M. T. C. C. De Souza (Org.). Os Sentidos de Construção: o si mesmo e o mundo. (pp. 37-50). São Paulo: Casa do Psicólogo.

De Souza, M. T. C. C. (2004). Alteridade na construção do "si mesmo". In. L. M. Simão e A. M. Martínez (Org.). O outro no desenvolvimento humano. (pp. 61-75). São Paulo: Thomson.

Darling, N., Steinberg, L. (1993). Parenting Style as Context: an Integrative Model. Psychological Bulletin, 13 (3), 487-496.

De Vries, R., Zan, B. (1998). A ética na educação infantil. D. Batista, Trad. Porto Alegre: Artmed.

Dornbusch, S. M, et al. (1985). Single Parents, Extended Households and the Control of Adolescents. Child Development, 56 (3), 326-341.

Durkheim, E. (1974/2002). La Educacion morale. EditoraTrota.

Elkind, D. (1975). Crianças e adolescentes. Ensaios interpretativos sobre Jean Piaget. Rio de Janeiro: Zahar.

Ericson, E. (1968/1976). Identidade: juventude e crise. A. Cabral, Trad. (2a ed.). Rio de Janeiro: Zahar.

Faber, A. \& Mazlish, E. (1985). Pais liberados. Filhos liberados. São Paulo: Ibrasa.

Faber, A \& Maslish, E. (2003). Como falar para o seu filho ouvir e como ouvir para o seu filho falar. São Paulo: Summus. 
Fiori, W. R. (1981). Modelo psicanalítico. In C. R. Rappaport, W. R. Fiori, C. Davis (1981). Psicologia do desenvolvimento: teorias do desenvolvimento, conceitos fundamentais. vol 1. (pp. 11-50). São Paulo: EPU.

Freitag, B. (1992). Itinerários de Antígona: a questão da moralidade. (2ª ed.) São Paulo: Papirus.

Freud, Anna. (1936/86). O ego e os mecanismos de defesa. A. Cabral, Trad. (8a ed.). Rio de Janeiro: Civilização Brasileira.

Freud, S. (1923/2006). O ego e o id e outros trabalhos. vol XIX. Rio de Janeiro: Imago. (1929/1971). Mal estar na civilização. J. O. A. Abreu, Trad. Rio de Janeiro: Imago.

Gallatin, J. E. (1942/78). Adolescência e individualidade: uma abordagem conceitual da Psicologia da Adolescência. A. C. Amador Pereira e R. Amador Pereira, Trads. São Paulo: Editora Harper \& Row do Brasil Ltda.

Gilligan, C. (1982). Uma voz diferente. Rio de Janeiro: Editora Rosa dos Ventos.

Gilligan. (1988/2001). Adolescent Development Reconsidered. In C. Gilligan, J. V. Ward, J. M. Taylor (Orgs.). Mapping de Moral Domain: a contribution of women's thinking to psychological theory and education. Cambridge: Harvard University Press

Garson, D. G. PA765 - Statnotes: an online textbook. Disponível em: <http://www2.chass.ncsu.edu/garson/pa765/structur.htm>. Acesso em: 06 julho 2009.

Giacomoni, C. H. \& Hutz, C. S. (2006). Escala de afeto positive e negative para criança: estudos de construção e validação. Revista da ABRAPEE, 10 (2), 235-245.

Ginot, H. (1989). Pais e jovens. L. S. Sweet, Trad. Rio de Janeiro: Bloch.

Gomide, P. I. C. (2006). Inventário de Estilos Parentais (IEP). Petrópolis: Vozes.

Goossens, L. (2006). Theories of Adolescence. In Jackson S. \& Goossens, L. (edt.). Handbook of adolescent development. (pp. 11-26). EUA and Canadá: Psychology Press.

Goossens, L. (2006). The many faces of adolescent autonomy: Parent-adolescent conflict, behavioral decision-making, and emocional distancing. In Jackson S. \& Goossens, L. (edt.). Handbook of adolescent development. (pp. 118-131). EUA and Canadá: Psychology Press. 
Grossman, E. (1998, jul/set). A adolescência através dos tempos. Adolescência Latinoamericana, 1(2), 68-74.

Grotevant, H. D. \& Cooper, C. R. (1986). Individuation in Family Relationships. Human Development, 29, 82-100.

Hair Jr., F. et al. (1998). Multivariate data analysis. New Jersey: Prentice Hall.

Hall, G. S. (1904). Adolescence. New York: Apletton. 2 vols.

Hasebe, Y., Nucci, L., Nucci, M. (1904). Parental Control of the personal domain and adolescent symptoms of psychopathology: a cross-nacional study in the United States and Japan. Child Development, 75(3), 815-828.

Hoffman, M. L. (1970) Desenvolvimento Moral. In L. Carmichael.(1898/1975). Manual de Psicologia da Criança. Vol 9 (II). P. Mussen (org da ed. original); S. P. Netto (coord. ed. Brasileira).(pp. 1-159). São Paulo: EPU (ed. Da Universidade de São Paulo).

Holden, G. W., Edwards, L. A. (1989). Parental Attitudes Toward Child Rearing: Instruments, Issues and Implications. Psychological Bulletin, 106 (1), 29-58.

Inhelder, B. \& Piaget, J. (1970/76). Da lógica da criança à lógica do adolescente. D. M. Leite, Trad. São Paulo: Pioneira.

Jackson S. \& Goossens, L. (edt.)., 2006. Handbook of adolescent development. EUA and Canadá: Psychology Press.

Jiménez, A. P. \& Delgado, A. O. (2002). Comunicación y conflicto familiar durante la adolescencia. Anales de Psicologia, 18 (2), 215-231.

Jöreskog, K. et al. (2000). LISREL 8: new statistical features. Chicago: Scientific Software International.

Kamii, C. e Declark, G. (1988). Autonomia como finalidade da educação (segundo Piaget). In C. Kamii, \& G. Declark. Reinventando a aritmética: implicações da teoria de Piaget.(E. Curt, Trad.). Campinas:Papirus. 
Kamii, C. (1991) Obediência não é o bastante. In Coletânea AMAE-Educando: Construindo a alfabetização. (pp.38-40).Belo Horizonte, MG: Almeida Publicidade.

Killen, M. \& Smetana, J. (edt.), 2005. Handbook of moral development. EUA: Lawrence Erlbaum Associates.

Kohlberg, L. (1963/2008). The development of childrens's orientations toward a moral order. Human development.51, 8-20. Reprinted of Vita Humana 1963: 6:11-33.

Kohlberg, L. (1981,1984, 1987). Essays on moral development. São Francisco: Harper \& Row.

Kohlberg, L. (1989). Estadios morales y moralización. El enfoque cognitivo-evolutivo. In Turiel, E., Enesco, I. \& Linaza, J. (Compiladores). (1989). El mundo social em la mente infantil. (pp.309-322). Madrid: Alianza Editorial.

La Taille, Y. (1994) Prefácio à edição Brasileira .In J. Piaget.(1932/2000). O juízo moral na criança. E. Leonardon, Trad.(2a ed.).(pp. 7-20). São Paulo: Summus

La Taille, Y. (1996) A Educação Moral: Kant e Piaget. In L. de Macedo (Org.). Cinco estudos de educação moral.(2a ed). (pp.137-178). São Paulo: Casa do Psicólogo.

La Taille, Y..(1998) Limites: três dimensões educacionais. São Paulo: Editora Ática.

La Taille, Y. (2002). Vergonha a ferida moral. São Paulo: Editora Vozes.

La Taille, Y. (2003). Cognição, Afeto e Moralidade. In. U. F. Araújo (coord). Psicologia, Educação e As Temáticas da Vida Contemporânea. São Paulo: Moderna.

La Taille, Y. (2006). Moral e Ética: dimensões intelectuais e afetivas. Porto Alegre: Artmed.

La Taille, Y. (2008). Desenvolvimento Humano: Contribuições da Psicologia Moral. Psicologia USP, São Paulo, 18 (1), 11-36.

La Taille, Y. (2009). Formação Ética: do tédio ao respeito de si. Porto Alegre: Artmed. 
La Taille, Y. (2009b). Prefácio. In Dinâmicas para reunião de pais: construindo a parceria na relação escola e família. São Paulo: Paulinas.

La Taille, Y; Souza, L.S; Vizioli, L. (2004). Ética e educação: uma revisão da literatura educacional de 1990 a 2003. Educação e Pesquisa, São Paulo, 26 (1), 91-108.

Lamborn, S. D., Mounts, N. S., Steinberg, L., S. M. Dornbusch (1991). Patterns of Competence and Adjustment among Adolescents from Authorative, Authoritarian, Indulgent and Neglectful Families. Child Development, 62 (5), 1049-1065.

Lapsley, D. K. (2005). Moral Stage Theory. In Killen, M. \& Smetana, J. (edt.), 2005. Handbook of moral development. EUA: Lawrence Erlbaum Associates.

Laursen, B., Coy, K. C., Collins, W. A. (1998). Reconsidering Changes in Parent-Child across Adolescence: A Meta-Analysis. Child Development, 69 (3), 817-832.

Lehalle, H. (2006). Moral Development in adolescence: How integrate personal and social values. In Jackson S. \& Goossens, L. (edt.). Handbook of adolescent development. (pp. 118131). EUA and Canadá: Psychology Press.

Lerner, R. M. (1998). Adolescent development: challenges and opportunities for research, programs, and policies. Annual Revew Psychology, 49, 413-446.

Levin, J. (1987). Estatística Aplicada a Ciências Humanas. (2a ed). São Paulo: Harbra,1987.

Lila, M., et al. (2006). Families and adolescents. In Jackson S. \& Goossens, L. (edt.). Handbook of adolescent development. (pp. 154-169). EUA and Canadá: Psychology Press.

Lopes, R. C. S. (1994). O contexto familiar no desenvolvimento da autonomia e da moralidade na adolescência. Psicologia: Reflexão e Crítica, 7 (1), 59-74.

Lukjanenko, M. F. (2001). A reciprocidade moral: avaliação e implicações educacionais. Tese de doutorado, Faculdade de Educação, Universidade de Campinas, Campinas.

Macedo, L. (1996). O lugar dos erros nas leis ou nas regras. In L. de Macedo (org.). Cinco estudos de educação moral. (pp. 177-209). (2a ed). São Paulo: Casa do Psicólogo. 
MacCallum, R.C.; Austin, J. T. (2000). Applications of structural equation modeling in psychological research. Annual Review of Psychology, 51, 201-226

Maccoby, E. E. \& Martin, J. A. (1983). Socialization in the context of the family: parent-child interaction. In Paul H. Mussen (Editor). Handbook of child psychology. Vol. 4: socialiation, personality, and social development. (4a ed.). (pp. 1-101). Nova York: John Wiley \& Sons.

Malhotra, N. (2006). Pesquisa de Marketing: uma Orientação Aplicada. (4a ed.). Porto Alegre: Bookman.

Mantovani de Assis, O. Z. (2000). Moralidade infantil. Revista do Professor. Porto Alegre: RS, 16 (63), 10-14.

Mantovani de Assis, O. Z. e Camargo de Assis, M. (orgs). (2002). Proepre: Fundamentos Teóricos. (3a ed). Campinas: Unicamp/ FE/ LPG.

Marques, M. A. B. (2000). Abuso psicológico de crianças e adolescentes. In F. F. Sisto, G. de C. Oliveira, L. D. T. Fini (Orgs.), Leituras de Psicologia para a Formação de Professores. (pp. 205-223). Petrópolis, RJ: Vozes.

Maroco, J. (2005). Análise Estatística: com a Utilização do SPSS. (2a ed.). Lisboa: Ed. Silabo.

Menin, M. S.S. (1996). Desenvolvimento Moral: Refletindo com pais e professores. In L. de Macedo (org.). Cinco estudos de educação moral. (pp. 37-104).(2a ed). São Paulo: Casa do Psicólogo.

Menin, M. S.S. (2005). Representações sociais de leis, crime e injustiça em adolescentes.. Campinas: Mercado das Letras.

Milgran, S. (1963). Behavioral Study of Obedience. Journal of Abnormal and Social Psychology, 67 (4), 371-378.

Montemayor, R. (1983). Parents and adolescents in conflict: all families some of the time and some families most of the time. Journal Early Adolescence, 3, 83-103.

Nogueira, M. A., Romanelli, G., Zago, N. (Orgs). (2000). Família e escola: trajetórias de escolarização em camadas médias e populares. Petrópolis, RJ: Vozes. 
Noronha, A. P. P., Alchieri, J. C. (2005). Reflexões sobre os instrumentos de avaliação psicológica. In R. Primi (org.). Temas em avaliação psicológica. (pp. 19-36). São Paulo: Casa do Psicólogo; Porto Alegre: IBAP - Instituto Brasileiro de Avaliação Psicológica.

Nucci, L. (1981). Conceptions of Personal Issues: A Domain Distinct from Moral or Societal Concepts. Child Development, 52 (1), 114-121.

Nucci, L. (2001). Psicologia moral e educação: para além de crianças "boazinhas". Educação e Pesquisa, São Paulo, 26 (2), 71-89.

Nucci, L., Hasebe, Y., Lins Dyer, M. T. (2005). Adolescent Psychological Well-Being and Parental Control of the Pesonal. New Directions for Child and Adolescent Development, 108, 17-30.

Oliva, A. (2004). Desenvolvimento social durante a adolescência. In Coll,C., Marchesi, A., Palacios, J. (Orgs). (2004). Desenvolvimento Psicológico e educação. D. V. de Moraes, Trad. (2a ed.). (pp.350-367). Porto Alegre: Artmed.

Oliveira, C. A. A. \& Bellico da Costa, A. E. (1997). Categorias de conflitos no cotidiano de adolescentes mineiros. Psicologia: reflexão e crítica, 10 (1), 583-607.

Palacios, J \& Oliva, A. (2004). A adolescência e seu significado evolutivo. In Coll,C., Marchesi, A., Palacios, J. (Orgs). (2004). Desenvolvimento Psicológico e educação. D. V. de Moraes, Trad. (2a ed.). (pp.309-322). Porto Alegre: Artmed.

Papalia, D. \& Olds, S.W. (1998). Desenvolvimento social e da personalidade na adolescência. In D. Papalia \& S. W. Olds (1998). O mundo da criança. M. L. G. L. Rosa, Trad. (8a ed.). (pp.537-553). São Paulo: Markon Books.

Papalia, D. (2006). Desenvolvimento físico, cognitivo e psicossocial na adolescência. In Papalia, D. E., Olds, S. W. e Feldman, R. D. (Orgs). (2006). Desenvolvimento humano. D. Bueno, Trad. (8a ed.). (pp.438-510). Porto Alegre: Artmed.

Paro, V. H. (2000). Qualidade do ensino: A contribuição dos pais. São Paulo: Xamã.

Pasquali, L. (2003). Psicometria: teoría dos testes na psicologia e na educação. Petrópolis: Vozes.

Petersen, A. (1988). Adolescent development. Annual Revew Psychology, 39, 583-607. 
Perkins, S. A. \& Turiel, E (1988). To lie or not to lie: to whom and under what circumstances. Child Development, 78(2), 609-621.

Piaget, J. (1926/1947). La Représentation du monde chez l'enfant. Paris: Presses Universitaires de France.

Piaget, J. (193O/1994). Os Procedimentos da Educação Moral. In L. de Macedo(1996). (org.). Cinco estudos de educação moral. (2a ed). (pp. 1-36). São Paulo: Casa do Psicólogo.

Piaget, J. (1932/1994). O juízo moral na criança. E. Leonardon, Trad. (2a ed.). São Paulo: Summus.

Piaget, J. (1934a/1998). É possível uma educação para a paz? In S. Parrat-Dayan, \& A. Tryphon (Orgs.).(1998). Sobre a pedagogia: textos inéditos (C. Berliner, Trad).(pp. 153-160). São Paulo: Casa do Psicólogo.

Piaget, J. (1934b/1998). Observações psicológicas sobre o self-government. In S. ParratDayan, \& A. Tryphon (Orgs.).(1998). Sobre a pedagogia: textos inéditos (C. Berliner, Trad).(pp. 153-160). São Paulo: Casa do Psicólogo.

Piaget, J. (1936/1970). O nascimento da inteligência na criança. A.Cabral, Trad. Rio de Janeiro: Zahar Editores.

Piaget, J. (1945/1998). A educação e a liberdade. In S. Parrat-Dayan, \& A. Tryphon (Orgs.).(1998). Sobre a pedagogia: textos inéditos (C. Berliner, Trad).(pp. 153-160). São Paulo: Casa do Psicólogo.

Piaget, J. (1947/1998). O desenvolvimento moral do adolescente em dois tipos de sociedade: sociedade primitiva e sociedade moderna. In S. Parrat-Dayan, \& A. Tryphon (Orgs.).(1998). Sobre a pedagogia: textos inéditos (C. Berliner, Trad).(pp. 161-166). São Paulo: Casa do Psicólogo.

Piaget, J. (1948/2000). Para onde vai a Educação? (I. Braga, Trad). (15 ed.). Rio de janeiro: José Oympio Editora.

Piaget, J. (1954/1994). Las relaciones entre la inteligencia y la afectividad en el desarrollo Del niño. In G. Delahanty, \& J. Pérez. (Comp.). (1994). Piaget y el Psicoanálisis. (pp. 181-289) .México: Universidad Autonoma Metropolitana. 
Piaget, J. (1957/1978) Piaget: problemas de psicologia genética. Traduções de Nathanael C. Caixeiro, Zilda A. Daeir, Célia E. A.Di Pero. (pp. 209-293). São Paulo: Abril Cultural. Coleção "Os pensadores".

Piaget, J. (1964/1986). Seis Estudos de Psicologia. M. A. M. D’Amorim e P.S. Lima Silva, Trad. Rio de janeiro: Forense-Universitária

Piaget, J. (1965/197). Estudos Sociológicos.R. Di Piero, Trad. Rio de janeiro: ForenseUniversitária.

Piaget, J. (1975). A teoria de Jean Piaget. In: Michael, Carl. Manual de Psicologia da Criança: Desenvolvimento cognitivo I. Vol 4. Org da edição original: Paul Mussen; coord da ed. Brasileira Samuel Pfromm Netto. EPU. Ed. Da Universidade de São Paulo.

Piaget, J. (2008). Intellectual Evolution from Adolescence to Adulthood. Human Development. 51, 40-47. Reprinted of Human Development 1972. 15, 1-12.

Piaget, J. \& Inhelder, B. (1966/1978). A Psicologia da Criança. (5 ed). O. M. Cajado Trad. Rio de Janeiro: Difel.

Polonia, A. C., Dessen, M. A. (2005). Em busca de uma compreensão das relações entre família e escola. Psicologia escolar e educação, 9 (2), 1-16.

Pratt, M. W., Arnold, M. L., Pratt, A. T., Diessner, R. (1999). Predicting Adolescente Moral Reasoning from Family Climate: a longitudinal study. Journal of Early Adolescence, 19 (2), 148-175.

Prust, L. W. \& Gomide, P. I. C. (2007). Relação entre comportamento moral dos pais e dos filhos adolescentes. Estudos de Psicologia, 24 (1), 53-60.

Roudinesco, E. (2003). A família em desordem. A. Telles, Trad. Rio de Janeiro: Jorge Zahar Editora.

Sá, V. (2001). A (Não) Participação dos Pais não Escola: a eloquência das ausências. In: Veiga, Ilma P. A.; Fonseca, Marília (orgs). Dimensões do Projeto Político Pedagógico. Campinas: Ed. Papirus.

Salvo, C. G., Silvares E. F. M., Toni, P. M. (2005). Práticas Educativas como forma de predição de problemas de comportamento e competência social. Estudos de Psicologia, 22 (2), 187-195. 
Sastre, G., Moreno, M. (2002). Resolução de conflitos e aprendizagem emocional. A. V. Fuzatto, Trad. São Paulo: Moderna.

Savater, F. (2004). Ética para o meu filho. M. Stahel, Trad. (3a ed.) São Paulo: Martins Fontes.

Sayão, R. (2003). Como educar meu filho. São Paulo: editora Publifolha.

Sayão, R., Aquino, J. G. (2006). Família: modos de usar. São Paulo: Papirus.

Shafer, D. R. (2005). Agressividade, altruísmo, desenvolvimento moral e família. In D. R. Shafer (2005). Psicologia do desenvolvimento: infância e adolescência. C. R. P. Cancissu, Trad. (pp.512-574). São Paulo: Pioneira Thomson Learning.

Selman, R. (1989). El desarollo sociocognitivo. Uma guia para la prática educativa y clínica. In Turiel, E., Enesco, I. \& Linaza, J. (Compiladores). (1989). El mundo social em la mente infantil. (pp.101-124). Madrid: Alianza Editorial.

Siegel, S. (1979). Estatística Não-Paramétrica: Para as Ciências do Comportamento. São Paulo: McGraw-Hill.

Silverberg, S. B \& Steinberg, L. (1987). Adolescent Autonomy, Parent-Adolescent Conflict, and Parental Well-Being. Journal of Youth and Adolescence, 16 (3), 293-312.

Smetana, J. G. (1989). Adolescent' and Parents' Reasoning about actual Family Conflict. Child Development, 60, 1052-1067.

Smetana, J. G. (1994). Adolescents' and Parents' Conceptions of Parental Authority and Personal Autonomy. Child Development, 65(4), 1143-1158.

Smetana, J. G. (1999).The role of parents in moral development: a social domain analysis. Journal of Moral Education, 28(3), 311-321.

Smetana, J. G., Campione-Barr, N., Daddis, C. (2004). Longitudinal development of family decision making: defining healthy behavioral autonomy for Middle-Class African American Adolescents, Child Development. 75(5), 1418-1434. 
Smetana, J. G., Crean, H. F., Campione-Barr, N. (2005). Adolescent's and Parent's changing Concepcions of Parental Autohrity. In J. G. Smetana (ed.), Changing boundaries of parental authority during adolescence (p.31-46). New Directions for Child and adolescent Development. San Francisco: Jossev-Bass.

Smetana, J. G., Campione-Barr, N., Metzger, A. (2006). Adolescent development in Interpersonal and Societal Contexts. Annual Review Psychology. 51, 255-284.

Smetana, J. G., Metzger, A., Gettman, D. C., Campione-Barr, N., (2006). Disclosure and Secrecy in Adolescent-Parent Relationship. Child Development. 77(1), 201-217.

SPSS - Statistical Package for the Social Sciences. (1999). Base 10.0 User's Guide. Chicago: SPSS.

Steinberg, L. (2001). We know some things: parent-adolescent relationships in retrospect and prospect. Child Development, 57, 841-851.

Steinberg, L. \& Silverberg, L. (1986). The vicissitudes of autonomy. Child Development, 57, 841-851.

Steinberg, L. \& Morris, A. S. (2001). Adolescent development. Annual Revew Psychology, $52,83-110$.

Szymanski, H. (2007). A relação família e escola: desafios e perspectivas. Brasília: Liber Livro.

Teixeira, M. A. P., Oliveira, A. M. \& Wottrich, S. H. (2006). Escalas de Práticas Parentais (EPP): Avaliando Dimensões de Práticas Parentais em Relação a Adolescentes. Psicologia Reflexão e Crítica, 19 (3), 433-441.

Tiba, I. (2009). Famílias de alta performance: conceitos contemporâneos na educação. São Paulo: Integrare Editora.

Thoma, S. J. (2005). Research on the Defining Issues Test. In M. Killen and J. Smetana (orgs). Handbook of Moral Develoment. New Jersey: Lawrence Erlbaum Associates.

Turiel, E. (1983). The development of social knowledge: Morality and convention. Cambridge: Cambridge University Press. 
Turiel, E. (1989). Dominios y categorías en el desarrollo cognitivo y social. In Turiel, E., Enesco, I. \& Linaza, J. (Compiladores). (1989). El mundo social em la mente infantil. (pp.309-322). Madrid: Alianza Editorial.

Turiel, E. (1998). The development of morality. In W. Damon (Editor in chief). Handbook of child psychology. Vol. 3: Social, emotional, and personality development. (5a ed.) (pp. 863932). Nova York, John Wiley \& Sons, Inc.

Turiel, E. (2005). The many faces of parenting. New Directions for Child and adolescent Development. 108, 79-88.

Urbina, S. (2004/2007). Fundamentos da testagem psicológica. C. Dornelles, Trad. Porto Alegre: Artmed.

Youniss, J \& Ketterlinus, R. D. (1987). Communication and Connectedness in Mother and Father Adolescent Relationships. Journal of Youth and Adolescence, 16 (3), 265-279.

Youniss, J \& Smollar, J. (1985). Adolescent Relations with Mothers, Fathers, and Friends. Chicago and London: The University of Chicago Press.

Walker, L. J. \& Taylor, J. H. (1991). Family Interactions and the Development of Moral Reasoning. Child Development, 62, 264-283.

Weber, L. N. D., Prado, M. P., Viezzer, A. P., Brandenburg, O. J. (2004). Identificação de Estilos Parentais: O ponto de vista dos pais e dos filhos. Psicologia: reflexão e crítica, 17 (3), 323-331.

Winnicott, D. W. (1965/2001). A família e o desenvolvimento individual. M. B. Cipolla, Trad. São Paulo: Martins Fontes.

Winnicott, D. W. (1986/2005). Tudo começa em casa. P. Sandler, Trad. São Paulo: Martins Fontes.

Xypas, C. (1997). Piaget e a educação. M. F. Oliveira, Trad. Lisboa: Instituto Piaget. 


\section{ANEXO A \\ TERMO DE CONSENTIMENTO LIVRE E ESCLARECIDO}

\section{Pesquisa}

Pais, adolescentes e autonomia moral: Escala de Concepções Educativas.

\section{Natureza da pesquisa}

Você será convidado para participar dessa pesquisa que tem como finalidade investigar os conceitos determinantes da intervenção dos genitores no processo de construção da autonomia moral do adolescente. Além disso, a pesquisa pretende validar a partir dos dados colhidos, um novo instrumento de avaliação psicológica sobre as relações entre pais e adolescentes e a influência de tal relação na construção da autonomia moral.

\section{Participantes da pesquisa}

Pais e mães de adolescentes de 12 a 20 anos.

\section{Envolvimento na pesquisa}

Você será convidado a avaliar por escrito, frases que dizem respeito a sua relação com seus filhos, sendo que, o material deve ser respondido na escola de seu filho e a duração da participação na pesquisa é de meia hora.

\section{Riscos e desconforto}

A participação nessa pesquisa não traz nenhum tipo de complicação ou riscos de qualquer espécie.

\section{Confidencialidade}

Todas as informações coletadas nesse estudo são estritamente confidenciais. Apenas o pesquisador e seu orientador terão conhecimento dos dados.

\section{Benefícios}

Participando da pesquisa você não terá nenhum benefício direto. Entretanto, a sua participação contribuirá para o aprofundamento do estudo a respeito das relações interpessoais entre pais e filhos e a construção da personalidade moral do adolescente.

\section{Pagamento}

Você não terá nenhum tipo de despesa para participar dessa pesquisa. Também nada será pago por sua participação.

Tendo em vista os itens acima apresentados, eu, de forma livre e esclarecida, manifesto meu interesse em participar da pesquisa. 
Nome do pai ou mãe

Local e data

Pesquisadora: Luciana Maria Caetano

Orientadora: Prof. Assistente Dra. Maria Thereza Costa Coelho de Souza

Dados do Participante:

Nome do Colégio ou Escola:

Cidade:

Idade:

Formação escolar:

Estado civil:

Profissão:

Renda Familiar:

Número de filhos:

Nome e idade dos filhos:

1 idade:

2 idade:

$3-$ idade:

4 idade:

$5-$ idade:

6 idade: 


\section{ANEXO B \\ Instrumentos aplicados no Estudo Piloto \\ Pais e adolescentes: Escala de Juízo (PAEJ)}

Avalie as frases abaixo, atribuindo uma nota de 1 a 4 . Conforme o quadro que se segue:

\begin{tabular}{|c|c|c|c|}
\hline 1 & 2 & 3 & 4 \\
\hline $\begin{array}{c}\text { Discordo } \\
\text { muito }\end{array}$ & Discordo & Concordo & $\begin{array}{c}\text { Concordo } \\
\text { muito }\end{array}$ \\
\hline
\end{tabular}

\begin{tabular}{|c|c|}
\hline Frases & Notas \\
\hline 1- Um pai sempre deve mostrar interesse pelas coisas que o filho faz. & 4 \\
\hline 2- Um pai nunca deve mexer nas coisas do filho sem pedir permissão. & 4 \\
\hline 3- Os pais devem ignorar as explicações dos filhos. & 1 \\
\hline 4- Quando um pai dá uma ordem, ela deve ser acompanhada de sua razão de ser. & 4 \\
\hline 5- Quando o filho faz alguma coisa errada, o pai deve proibi-lo de fazer algo que ele goste. & 1 \\
\hline $\begin{array}{l}\text { 6- Mesmo que o filho não queira conversar, é dever dos pais insistir para saber o que se passa na vida do } \\
\text { filho. }\end{array}$ & 4 \\
\hline 7- Cabe aos pais tomar as decisões pelos filhos. & 1 \\
\hline 8- Os filhos desobedientes devem saber que deixam os seus pais tristes. & 1 \\
\hline 9- Os pais devem sempre contornar os erros dos filhos para não viverem brigando com eles. & 1 \\
\hline 10 - Os pais devem usar ofensas quando necessário para educar seus filhos. & 1 \\
\hline 11- Um pai deve sempre se auto-controlar para castigar seu filho. & 4 \\
\hline 12- Um pai nunca deve confiar no filho. & 1 \\
\hline 13- Os filhos, quando autorizados pelos pais, devem ter suas próprias experiências. & 1 \\
\hline 14- Um pai não deve sempre justificar para os filhos as suas orientações. & 1 \\
\hline 15- Os pais devem sempre se esforçar para entender as razões da desobediência dos seus filhos. & 4 \\
\hline 16- Quando o filho faz algo errado, os pais devem bater nele para lhe corrigir. & 1 \\
\hline 17- Os pais devem dar palpite em tudo o que o filho faz. & 1 \\
\hline 18- Os pais precisam saber o que é melhor para o seu filho. & 3 \\
\hline $\begin{array}{l}\text { 19- Um pai que tem dois filhos precisa sempre agir do mesmo modo com os } \\
\text { dois. }\end{array}$ & 2 \\
\hline 20- Um pai nunca deve trocar idéias com seus filhos. & 1 \\
\hline 21- Ajudar os filhos a refletirem sobre suas ações é melhor que dar ordens. & 4 \\
\hline 22- Um filho sempre deve acatar as ordens dos pais. & 2 \\
\hline 23- Um pai deve resolver uma desobediência com uma boa ameaça. & 1 \\
\hline 24- Um pai deve ajudar seu filho a arcar com as consequiências dos seus atos. & 4 \\
\hline 25- Os pais devem oferecer oportunidades & 4 \\
\hline
\end{tabular}




\begin{tabular}{|l|c|}
\hline & \\
\hline 26- O dever dos pais é ser coerente com as atitudes junto aos seus filhos. & 4 \\
\hline 27- Os pais devem sempre permitir que seus filhos busquem soluções para os seus próprios problemas. & 3 \\
\hline 28- Deve-se obedecer aos pais mesmo quando suas regras forem inadequadas. & 1 \\
\hline 29- Cabe aos pais darem soluções para as situações difíceis pelas quais passam seus filhos. & 2 \\
\hline 30- Os filhos que amam seus pais sempre devem lhes obedecer. & 1 \\
\hline 31- O papel dos pais é ser modelo para sustentar as regras impostas aos filhos. & 4 \\
\hline 32- Não se deve sempre ouvir os filhos. & 1 \\
\hline 33- Os pais nunca devem levar em consideração as opiniões dos filhos. & 1 \\
\hline 34- Os pais devem substituir os “longos sermões” por poucas palavras. & 4 \\
\hline 35- O pai pode falar e não agir conforme as suas palavras. & 1 \\
\hline 36- O dever dos filhos de respeitar os pais implica que os pais respeitem os filhos também. & 4 \\
\hline
\end{tabular}




\section{Pais e adolescentes: Escala de Intervenção (PAEI)}

Avalie as intervenções propostas abaixo para cada situação, atribuindo uma nota de 1 a 4 . Conforme o quadro abaixo. Em seguida escolha atitude que você tomaria no lugar dos pais desse jovem.

\section{$1^{a}$ Situação}

\begin{tabular}{|c|c|c|c|}
\hline 1 & 2 & 3 & 4 \\
\hline $\begin{array}{c}\text { Discordo } \\
\text { muito }\end{array}$ & Discordo & Concordo & $\begin{array}{c}\text { Concordo } \\
\text { muito }\end{array}$ \\
\hline
\end{tabular}

Um adolescente usa o carro da (o) mãe/ pai, sem a sua permissão. Além de usá-la sem permissão, a perde. O/a pai/mãe devem dizer:

a- Vá agora ao seu guarda-roupa, escolha uma de suas blusas preferidas, pois eu a doarei a uma instituição de caridade.

b- Não se pega as coisas dos outros sem pedir. O que fará agora para restituir o prejuízo que me causou?

c- Eu já cansei de lhe dizer para não pegar minhas coisas, pois você não tem zelo por nada, nem por si mesmo/a.

d- O que você precisa aprender é que não deve fazer para os outros o que não quer que façam a você. Você gostaria que eu perdesse uma blusa sua?

e- Como você é irresponsável. Que pessoa mais descuidada. É impossível emprestar coisas para você.

f- A partir de hoje você ficará bem longe do meu quarto, pois eu manterei meu quarto trancado até que me diga que posso confiar em você.

g- Temos um problema aqui: você usou a minha blusa sem autorização e a perdeu. O que tem a me dizer sobre isso?

Marque com um X a sua opção preferida:

\begin{tabular}{|c|c|c|c|c|c|c|}
\hline $\mathrm{A}$ & $\mathrm{b}$ & $\mathrm{c}$ & $\mathrm{D}$ & $\mathrm{E}$ & $\mathrm{F}$ & $\mathrm{g}$ \\
\hline & $\mathrm{X}$ & & & & & \\
\hline
\end{tabular}

\section{$2^{\text {a }}$ Situação}

Os pais têm dois filhos adolescentes. Um é obediente e o outro não. O que os pais devem fazer?

\begin{tabular}{|l|c|}
\hline $\begin{array}{l}\text { a- Os pais devem sempre privilegiar o filho mais obediente, dando-lhe, por exemplo, os melhores } \\
\text { presentes. }\end{array}$ & 1 \\
\hline $\begin{array}{l}\text { b- Os pais devem ressaltar o comportamento adequado do filho obediente, para que o outro aprenda a } \\
\text { imitá-lo. }\end{array}$ & 1 \\
\hline c- Os pais devem punir o filho que desobedece dando-lhe uma surra. & 1 \\
\hline d- Os pais devem ameaçar cortar a mesada do filho desobediente. & 1 \\
\hline e- Os pais devem sempre tratar com igualdade aos seus dois filhos. & 2 \\
\hline f- Os pais não devem comparar os seus filhos, pois cada ser humano é único. & 4 \\
\hline $\begin{array}{l}\text { g- Os pais devem dialogar com o filho desobediente, para que possam entender o que está se passando } \\
\text { com ele. }\end{array}$ & 3 \\
\hline
\end{tabular}
com ele.

Marque com um X a sua opção preferida:

\begin{tabular}{|c|c|c|c|c|c|c|}
\hline $\mathrm{a}$ & $\mathrm{b}$ & $\mathrm{c}$ & $\mathrm{D}$ & $\mathrm{E}$ & $\mathrm{F}$ & $\mathrm{g}$ \\
\hline & & & & & & $\mathrm{X}$ \\
\hline
\end{tabular}




\section{$3^{\text {a }}$ Situação}

O adolescente demonstra-se irritadiço e angustiado, pois não consegue disciplinar-se para estudar: não cumpre os prazos de entrega das tarefas extra-classe e se ocupa com outras tarefas não conseguindo se concentrar nos estudos. Os pais devem dizer:

a- O que é melhor para você? Que nos sentemos para estudarmos juntos agora ou prefere trabalhar sozinho e depois tirar suas dúvidas?

b- Vejo que está sendo difícil para você se concentrar. Como gostaria que eu o ajudasse?

c- Você escolhe: ou estuda pelo menos uma hora por dia religiosamente, ou ficará sem ver televisão até a próxima avaliação.

d- Temos um problema aqui: você tem dúvidas e não está conseguindo se concentrar. Quer conversar sobre isso?

e- Na sua idade, eu cumpria com as minhas obrigações, e olha que, além de estudar eu trabalhava 1

fora também. Você a partir de hoje vai ter aulas de reforço.

f- Você acha que poderia encontrar alguém que pudesse lhe ajudar com essa matéria? Ou será que 3 você teria uma outra solução?

g- Olhe bem, com essa sua falta de vontade, é melhor que se prepare para a recuperação nessa 1 disciplina.

Marque com um X a sua opção preferida:

\begin{tabular}{|c|c|c|c|c|c|c|}
\hline $\mathrm{a}$ & $\mathrm{b}$ & $\mathrm{c}$ & $\mathrm{D}$ & $\mathrm{E}$ & $\mathrm{F}$ & $\mathrm{G}$ \\
\hline $\mathrm{X}$ & & & & & & \\
\hline
\end{tabular}

\section{$4^{\mathrm{a}}$ Situação}

Os pais tinham dois filhos. Um sempre resmungava quando os pais lhes pediam para fazer uma compra, o outro não gostava de fazê-lo, mas ia sem dizer nada. O que os pais devem fazer?

\begin{tabular}{|l|c|}
\hline a- Os pais devem sempre pedir ao filho que não reclama para realizar a compra. & 1 \\
\hline b- Os pais não devem abusar do segundo filho, só porque ele não reclama. & 4 \\
\hline $\begin{array}{l}\text { c- Os pais devem punir o filho resmungão, dizendo-lhe que a solidariedade é um valor essencial a uma } \\
\text { boa pessoa. }\end{array}$ & 1 \\
\hline $\begin{array}{l}\text { d- Os pais devem apresentar a sua necessidade aos dois filhos e pedir que eles encontrem juntos um } \\
\text { modo de decidir quem vai as compras. }\end{array}$ & 4 \\
\hline $\begin{array}{l}\text { e- Os pais devem presentear o filho que não reclama e deixar o filho que sempre resmunga, sem } \\
\text { presente. }\end{array}$ & 1 \\
\hline $\begin{array}{l}\text { f- Quando o filho que sempre reclama, pedir algo aos pais, os mesmos devem se negar a lhe dar o que } \\
\text { pede também. }\end{array}$ & 1 \\
\hline $\begin{array}{l}\text { g- Os pais devem questionar o filho que não reclama, sobre o porquê sempre acata as ordens, ainda que } \\
\text { não o queira, e sem falar sobre o que sente. }\end{array}$ & 4 \\
\hline
\end{tabular}

Marque com um X a sua opção preferida:

\begin{tabular}{|c|c|c|c|c|c|c|}
\hline $\mathrm{A}$ & $\mathrm{b}$ & $\mathrm{C}$ & $\mathrm{D}$ & $\mathrm{E}$ & $\mathrm{F}$ & $\mathrm{G}$ \\
\hline & & & $\mathrm{X}$ & & & \\
\hline
\end{tabular}


ANEXO C

\section{CARACTERIZAÇÃO DOS PARTICIPANTES DO ESTUDO PILOTO}

\begin{tabular}{|c|c|c|c|c|c|c|c|c|}
\hline & Sexo & idade & Form.escolar & Est civil & Profissão & Renda & filhos & Idade dos filhos \\
\hline 1 & Pai & 45 & $2^{\circ} \mathrm{g}$ & casado & Ceramista & 1000,00 & 2 & 12,18 \\
\hline 2 & Pai & 39 & $2^{\circ} \mathrm{g}$. & casado & Auxiliar de líder & 1800,00 & 4 & $13,14,15,17$ \\
\hline 3 & Pai & 48 & $8^{\mathrm{a}}$ série & casado & Operador de máq. & 1539,00 & 5 & $13,15,23,25,28$ \\
\hline 4 & Pai & 44 & $8^{a}$ série & casado & Motorista & 1400,00 & 3 & $7,10,14$ \\
\hline 5 & Pai & 29 & $2^{\circ} \mathrm{g}$ & casado & Feirante & 1400,00 & 9 & \\
\hline 6 & Pai & 34 & $2^{\circ} \mathrm{g}$ & casado & Líder & 1000,00 & 2 & 8,13 \\
\hline 7 & Pai & 37 & $2^{\circ} \mathrm{g}$. incom. & casado & Ceramista & 1000,00 & 3 & $3,8,12$ \\
\hline 8 & Pai & 48 & $2^{\circ} \mathrm{g}$. & casado & Operador de máq. & 1000,00 & 4 & $5,8,13,24$ \\
\hline 9 & Pai & 43 & Superior & casado & Op. Tráfego & 1800,00 & 2 & 13,14 \\
\hline 10 & Pai & 35 & $2^{\circ} \mathrm{g}$ & casado & Tec enferm. & 1400,00 & 03 & $2,3,12$ \\
\hline 11 & Pai & 39 & $8^{a}$ série & casado & Lavrador & 480,00 & 5 & $12,13,14,16,19$ \\
\hline 12 & Pai & 40 & $4^{\mathrm{a}}$ série & casado & Aposentado & 1174,00 & 2 & 7,13 \\
\hline 13 & Mãe & 38 & $8^{a}$ série & separada & Doméstica & 500,00 & 3 & $10,12,15$ \\
\hline 14 & Mãe & 28 & $5^{\mathrm{a}}$ série & Amas. & Doméstica & 600,00 & 2 & 9,13 \\
\hline 15 & Mãe & 33 & $5^{\mathrm{a}}$ série & Amas. & Do lar & 800,00 & 2 & 14,16 \\
\hline 16 & Mãe & 42 & $2^{\circ} \mathrm{g}$ & casada & Do lar & 2800,00 & 4 & $8,8,12,14$ \\
\hline 17 & Mãe & 48 & $8^{a}$ série & Amas. & Do lar & 800,00 & 4 & $6,11,14,24$ \\
\hline 18 & Mãe & 32 & $2^{\circ} \mathrm{g}$ & casado & manicue & 900,00 & 2 & 9,13 \\
\hline 19 & Mãe & 33 & Sup (incomp) & casada & estagiária & 2000,00 & 1 & 13 \\
\hline 20 & Mãe & 36 & Pós-grad. & separada & professora & 1300,00 & 2 & 12,18 \\
\hline 21 & Mãe & 35 & superior & casada & professora & 2200,00 & 4 & $6,10,14,16$ \\
\hline 22 & Mãe & 41 & superior & casada & professora & 1100,00 & 2 & 13,18 \\
\hline 23 & Mãe & 31 & $2^{\circ} \mathrm{g}$ & casada & Do lar & 1700,00 & 2 & 7,13 \\
\hline 24 & Mãe & 50 & $2^{\circ} \mathrm{g}$. & casada & Do lar & 800,00 & 2 & 13,24 \\
\hline
\end{tabular}




\author{
ANEXO D \\ DATE: $\quad 9 / 14 / 2009$ \\ TIME : $12: 07$ \\ L I S R E L 8.72
}

BY

Karl G. Jöreskog and Dag Sörbom

\begin{abstract}
This program is published exclusively by
Scientific Software International, Inc.

$7383 \mathrm{~N}$. Lincoln Avenue, Suite 100

Lincolnwood, IL 60712, U.S.A.

Phone: (800)247-6113, (847)675-0720, Fax: (847)675-2140

Copyright by Scientific Software International, Inc., 1981-2005

Use of this program is subject to the terms specified in the

Universal Copyright Convention.

Website: www.ssicentral.com
\end{abstract}

The following lines were read from file C: \Documents and

Settings \DirceudS\Desktop \LUCIANA DOUTORADO\luciana simplis.spj:

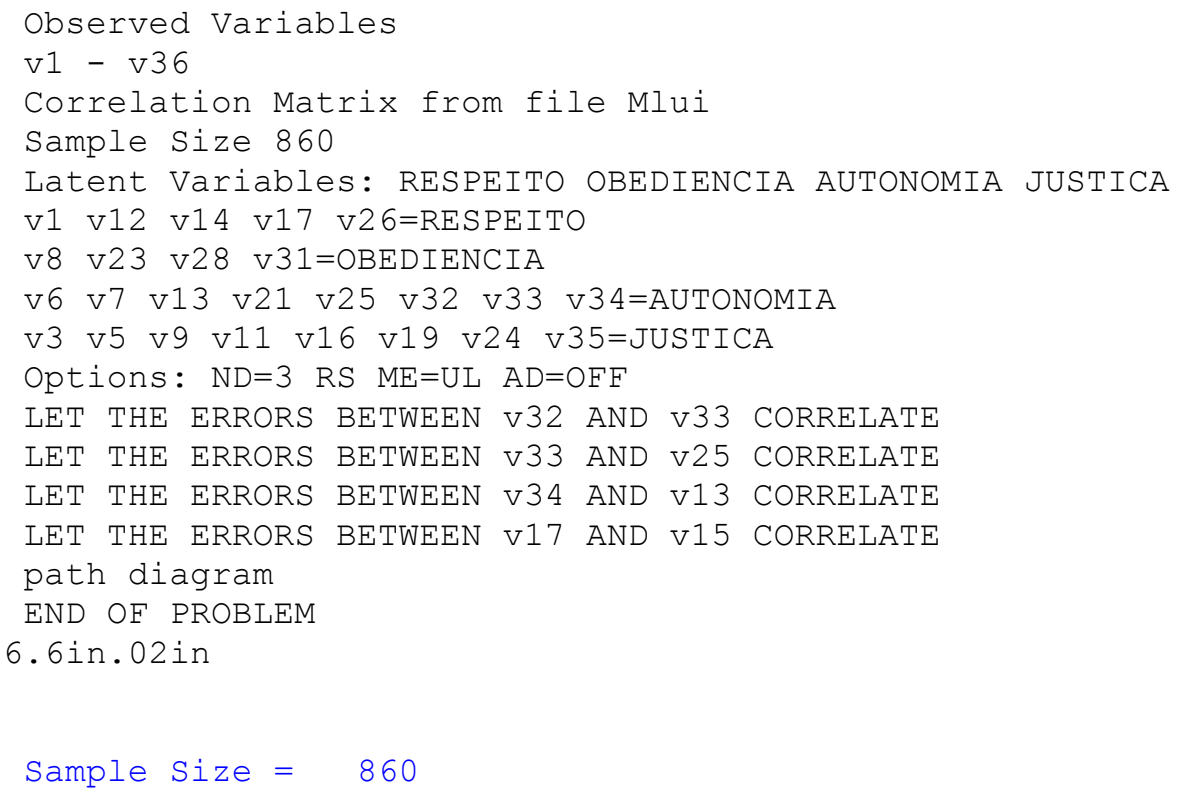

$\underline{\text { !Luciana CFA }}$

Correlation Matrix 


\begin{tabular}{|c|c|c|c|c|c|}
\hline v1 & 1.000 & & & & \\
\hline v3 & -0.039 & 1.000 & & & \\
\hline v5 & 0.111 & -0.028 & 1.000 & & \\
\hline v6 & -0.034 & -0.052 & 0.024 & 1.000 & \\
\hline v7 & 0.087 & 0.041 & 0.223 & 0.044 & 1.000 \\
\hline v8 & -0.004 & -0.033 & -0.073 & -0.027 & -0.225 \\
\hline v9 & 0.024 & 0.060 & 0.245 & -0.108 & 0.328 \\
\hline v11 & 0.008 & -0.049 & -0.077 & 0.017 & -0.362 \\
\hline v12 & 0.029 & -0.008 & -0.076 & 0.033 & -0.116 \\
\hline v13 & -0.085 & -0.025 & 0.087 & -0.091 & 0.206 \\
\hline v14 & 0.057 & -0.051 & -0.179 & -0.024 & -0.347 \\
\hline v15 & 0.017 & 0.005 & -0.034 & 0.086 & 0.038 \\
\hline v16 & -0.090 & -0.073 & 0.039 & -0.073 & -0.027 \\
\hline v17 & 0.057 & 0.008 & 0.046 & -0.021 & 0.279 \\
\hline v19 & 0.037 & -0.037 & -0.022 & 0.188 & -0.133 \\
\hline v21 & 0.033 & -0.020 & 0.102 & 0.111 & 0.208 \\
\hline v23 & 0.046 & 0.010 & 0.075 & 0.039 & 0.309 \\
\hline v24 & 0.080 & 0.082 & 0.153 & -0.003 & 0.239 \\
\hline v25 & -0.041 & 0.098 & 0.068 & -0.037 & 0.117 \\
\hline v26 & -0.062 & 0.035 & 0.085 & 0.070 & 0.407 \\
\hline v28 & 0.019 & -0.002 & 0.088 & 0.093 & 0.186 \\
\hline v31 & 0.066 & 0.040 & 0.158 & -0.065 & 0.201 \\
\hline v32 & -0.024 & -0.055 & -0.122 & 0.067 & -0.417 \\
\hline v33 & -0.037 & 0.009 & 0.086 & 0.035 & 0.239 \\
\hline v34 & 0.029 & -0.028 & 0.062 & 0.048 & 0.188 \\
\hline v35 & 0.050 & 0.034 & 0.033 & 0.091 & 0.045 \\
\hline
\end{tabular}

1.000
-0.159
0.130
-0.004
0.147
0.006
-0.080
0.032
-0.024
0.028
0.002
-0.032
-0.041
0.061
-0.107
-0.060
0.012
0.089
-0.070
-0.060
-0.036

Correlation Matrix

(continued)

\begin{tabular}{|c|c|c|c|c|c|}
\hline & v9 & v11 & v12 & v13 & v14 \\
\hline v9 & 1.000 & & & & \\
\hline v11 & -0.376 & 1.000 & & & \\
\hline v12 & -0.313 & -0.045 & 1.000 & & \\
\hline v13 & 0.179 & -0.037 & -0.111 & 1.000 & \\
\hline v14 & -0.345 & 0.134 & 0.157 & -0.101 & 1.000 \\
\hline v15 & -0.018 & 0.036 & -0.011 & 0.041 & -0.055 \\
\hline v16 & -0.046 & 0.029 & -0.049 & 0.104 & 0.019 \\
\hline v17 & 0.264 & -0.102 & -0.109 & 0.109 & -0.127 \\
\hline v19 & -0.108 & 0.042 & 0.093 & -0.092 & 0.084 \\
\hline v21 & 0.253 & -0.067 & -0.074 & 0.049 & -0.190 \\
\hline v23 & 0.344 & -0.197 & -0.096 & -0.047 & -0.171 \\
\hline v24 & 0.364 & -0.141 & -0.128 & 0.007 & -0.106 \\
\hline v25 & 0.137 & -0.020 & -0.080 & 0.003 & -0.055 \\
\hline v26 & 0.413 & -0.215 & -0.103 & -0.074 & -0.183 \\
\hline v28 & 0.208 & -0.112 & -0.116 & -0.059 & -0.080 \\
\hline v31 & 0.263 & -0.075 & -0.114 & 0.134 & -0.159 \\
\hline v32 & -0.433 & 0.213 & 0.183 & -0.110 & 0.156 \\
\hline v33 & 0.222 & -0.141 & -0.124 & 0.093 & -0.088 \\
\hline v34 & 0.222 & -0.125 & -0.063 & -0.133 & -0.072 \\
\hline & 0.116 & 0.004 & -0.016 & 0.010 & -0.029 \\
\hline
\end{tabular}

v15

1.000

0.068

0.177

0.101

$-0.025$

$-0.070$

0.064

0.137

0.023

$-0.018$

$-0.116$

0.175

$-0.153$

0.082

0.183

Correlation Matrix

(continued)

$\begin{array}{rr}\mathbf{v 1 6} & \mathbf{v 1 7} \\ 1.000 & \\ 0.153 & 1.000 \\ -0.045 & -0.097 \\ 0.088 & 0.065\end{array}$

v19

v21

v23 


\begin{tabular}{|c|c|c|c|c|c|c|}
\hline v23 & -0.135 & 0.078 & -0.062 & 0.211 & 1.000 & \\
\hline v24 & -0.093 & 0.093 & -0.080 & 0.165 & 0.388 & 1.000 \\
\hline v25 & 0.076 & 0.104 & -0.048 & 0.027 & 0.097 & 0.202 \\
\hline v26 & -0.050 & 0.139 & -0.133 & 0.150 & 0.379 & 0.374 \\
\hline v28 & -0.074 & 0.091 & -0.123 & 0.168 & 0.223 & 0.237 \\
\hline v31 & 0.066 & 0.112 & -0.173 & 0.339 & 0.100 & 0.137 \\
\hline v32 & 0.027 & -0.140 & 0.176 & -0.275 & -0.269 & -0.195 \\
\hline v33 & -0.025 & 0.051 & -0.112 & 0.196 & 0.163 & 0.072 \\
\hline v34 & -0.099 & 0.013 & 0.068 & 0.199 & 0.304 & 0.316 \\
\hline v35 & 0.054 & 0.152 & 0.006 & 0.047 & 0.070 & 0.148 \\
\hline
\end{tabular}

Correlation Matrix (continued)

\begin{tabular}{lrr} 
& v25 & v26 \\
v25 & 1.000 & \\
v26 & 0.186 & 1.000 \\
v28 & 0.150 & 0.279 \\
v31 & -0.017 & 0.178 \\
v32 & 0.000 & -0.262 \\
v33 & -0.071 & 0.158 \\
v34 & 0.097 & 0.296 \\
v35 & 0.195 & 0.139 \\
& \multicolumn{2}{c}{} \\
Correlation Matrix & (continued) \\
& \multicolumn{2}{c}{ v35 } \\
v34 & 1.000 & \\
v35 & 0.137 & 1.000
\end{tabular}

\section{$\underline{! \text { Luciana CFA }}$}

Number of Iterations $=32$

\section{LISREL Estimates (Unweighted Least Squares)}

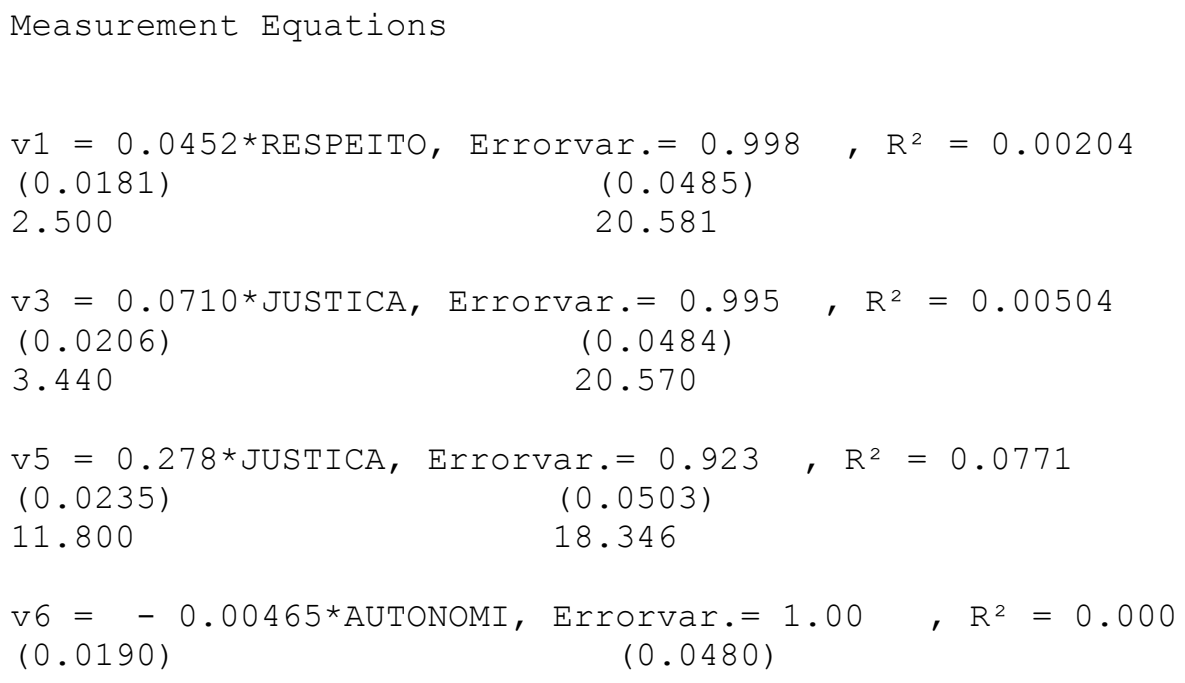




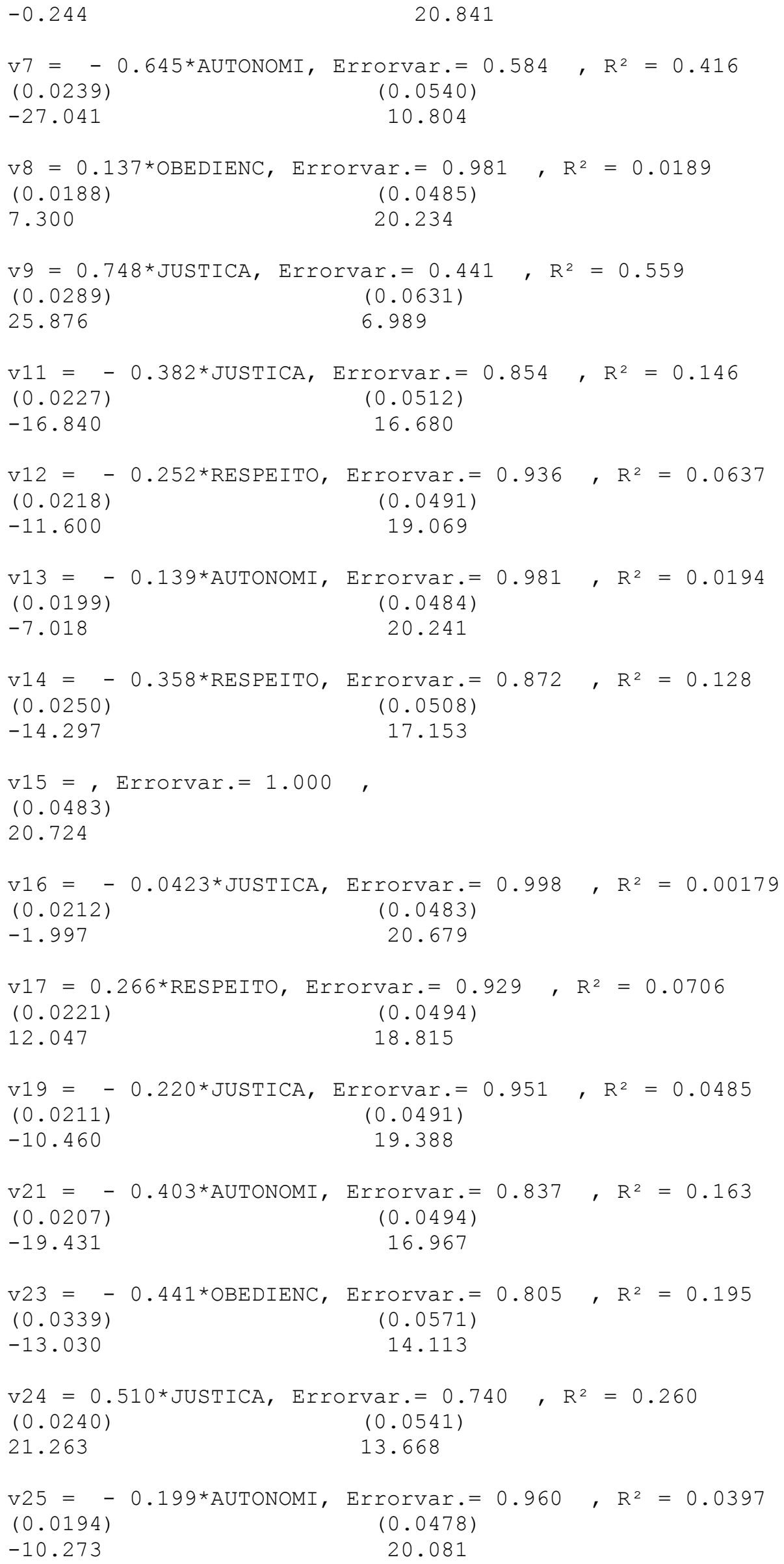




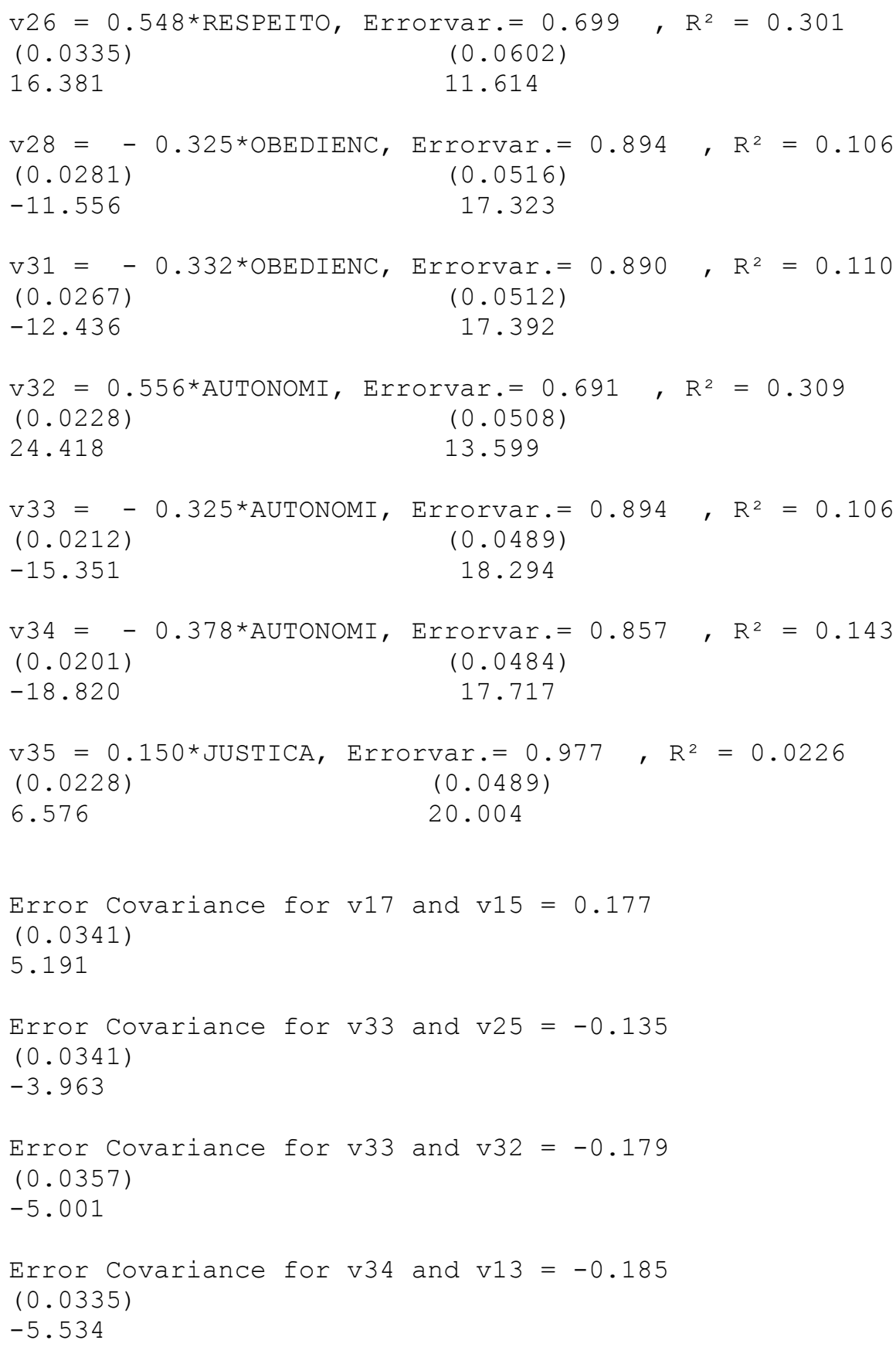

\section{Correlation Matrix of Independent Variables}

$\begin{array}{lrrrr} & \text { RESPEITO } & \text { OBEDIENC } & \text { AUTONOMI } & \text { JUSTICA } \\ \text { RESPEITO } & 1.000 & & & \\ \text { OBEDIENC } & -1.224 & 1.000 & & \\ & (0.119) & & & \\ \text { AUTONOMI } & -10.323 & & & \\ & -1.035 & 1.244 & 1.000 & \\ \text { JUSTICA } & (0.073) & (0.101) & & \\ & -14.184 & 12.317 & & \\ & 1.097 & -1.120 & -0.892 & \\ & (0.078) & (0.092) & (0.042) & \\ & 14.057 & -12.202 & -21.430 & \end{array}$




\title{
Goodness
}

of Fit

Statistics

\author{
W_A_R_N_I_N \\ $\overline{\mathrm{G}}: \mathrm{Ch} i \overline{-}$ \\ square, \\ standard \\ errors, t- \\ values and \\ standardize
}

d

residuals

are

calculated

under the

assumption

of multi-

variate

normality.

Degrees of

Freedom =

290

Normal

Theory

Weighted

Least

Squares

Chi-Square

$=1518.861$

$(P=0.0)$

Estimated

Non-

centrality

Parameter

$(\mathrm{NCP})=$

1228.861

90 Percent

Confidence

Interval

for $\mathrm{NCP}=$

(1110.628 ;

$1354.579)$ 
Function

Value =

1.335

Population

Discrepancy

Function

Value (FO)

$=1.431$

90 Percent

Confidence

Interval

for $\mathrm{FO}=$

(1.293 ;

1.577 )

Root Mean

Square

Error of

Approximati

on (RMSEA)

$=0.0702$

90 Percent

Confidence

Interval

for RMSEA =

(0.0668;

0.0737 )

P-Value for

Test of

Close Fit

(RMSEA <

$0.05)=$

0.000

Expected

Cross-

Validation

Index

$(\mathrm{ECVI})=$

1.910

90 Percent

Confidence

Interval

for $\mathrm{ECVI}=$

(1.773;

$2.057)$

ECVI for

Saturated

Model =

0.817

ECVI for

Independenc

e Model = 
6.984

Chi-

Square for

Independenc

e Model

with 325

Degrees of

Freedom =

5947.355

Independenc

e $\mathrm{AIC}=$

5999.355

Model $\mathrm{AIC}=$

1640.861

Saturated

AIC =

702.000

Independenc

e $\mathrm{CAIC}=$

6149.036

Model CAIC

$=1992.034$

Saturated

$\mathrm{CAIC}=$

2722.683

Normed Fit

Index (NFI)

$=1.000$

Non-Normed

Fit Index

$(\mathrm{NNFI})=$

1.058

Parsimony

Normed Fit

Index

$(\mathrm{PNFI})=$

0.892

Comparative

Fit Index

$(\mathrm{CFI})=$

1.000

Incremental

Fit Index

$(\mathrm{IFI})=$

1.051

Relative

Fit Index 
$(\mathrm{RFI})=$

1.000

Root Mean

Square

Residual

$(\mathrm{RMR})=$

0.0617

Standardize

d $\mathrm{RMR}=$

0.0617

Goodness of

Fit Index

$(\mathrm{GFI})=$

0.933

Adjusted

Goodness of

Fit Index

$(\mathrm{AGFI})=$

0.919

Parsimony

Goodness of

Fit Index

$(\mathrm{PGFI})=$

0.771

$\underline{\text { Luciana CFA }}$

\section{Fitted}

Covarianc

e Matrix

$v 1$
$v 3$
$v 5$
$v 6$
$v 7$
$v 8$
$v 9$
$v 11$
$v 12$
$v 13$
$v 14$
$v 15$
$v 16$
$v 17$
$v 19$
$v 21$
$v 23$
$v 24$
$v 25$

$\begin{array}{rrrrr}1.000 & & & & \\ 0.004 & 1.000 & & & \\ 0.014 & 0.020 & 1.000 & & \\ 0.000 & 0.000 & 0.001 & 1.000 & \\ 0.030 & 0.041 & 0.160 & 0.003 & 1.000 \\ -0.008 & -0.011 & -0.043 & -0.001 & -0.110 \\ 0.037 & 0.053 & 0.208 & 0.003 & 0.430 \\ -0.019 & -0.027 & -0.106 & -0.002 & -0.220 \\ -0.011 & -0.020 & -0.077 & -0.001 & -0.168 \\ 0.007 & 0.009 & 0.034 & 0.001 & 0.090 \\ -0.016 & -0.028 & -0.109 & -0.002 & -0.239 \\ --0 & -0.003 & -0.012 & 0.000 & -0.024 \\ -0.002 & -0.0101 & -177 \\ 0.012 & 0.021 & 0.081 & 0.001 & 0.177 \\ -0.011 & -0.016 & -0.061 & -0.001 & -0.127 \\ 0.019 & 0.026 & 0.100 & 0.002 & 0.260 \\ 0.024 & 0.035 & 0.137 & 0.003 & 0.354 \\ 0.025 & 0.036 & 0.142 & 0.002 & 0.293 \\ 0.009 & 0.013 & 0.049 & 0.001 & 0.128\end{array}$

$$
\begin{array}{r}
1.000 \\
-0.115 \\
0.059 \\
0.042 \\
-0.024 \\
0.060 \\
-\quad- \\
0.007 \\
-0.045 \\
0.034 \\
-0.069 \\
-0.061 \\
-0.079 \\
-0.034
\end{array}
$$




\begin{tabular}{|c|c|c|c|c|c|}
\hline v26 & 0.025 & 0.043 & 0.167 & 0.003 & 0.366 \\
\hline v28 & 0.018 & 0.026 & 0.101 & 0.002 & 0.261 \\
\hline v31 & 0.018 & 0.026 & 0.103 & 0.002 & 0.266 \\
\hline v32 & -0.026 & -0.035 & -0.138 & -0.003 & -0.359 \\
\hline v33 & 0.015 & 0.021 & 0.080 & 0.002 & 0.210 \\
\hline v34 & 0.018 & 0.024 & 0.093 & 0.002 & 0.244 \\
\hline v35 & & & $0 \cap 0$ & $0 \cap 01$ & \\
\hline
\end{tabular}

Fitted Covariance Matrix (continued)

\begin{tabular}{|c|c|c|c|c|c|}
\hline v9 & $\begin{array}{r}\mathbf{v 9} \\
1.000\end{array}$ & v11 & v12 & v13 & v14 \\
\hline v11 & -0.286 & 1.000 & & & \\
\hline v12 & -0.207 & 0.106 & 1.000 & & \\
\hline v13 & 0.093 & -0.048 & -0.036 & 1.000 & \\
\hline v14 & -0.293 & 0.150 & 0.090 & -0.052 & 1.000 \\
\hline v15 & $-\quad-$ & $-\quad-$ & $-\quad-$ & $-\quad-$ & - \\
\hline v16 & -0.032 & 0.016 & 0.012 & -0.005 & 0.017 \\
\hline v17 & 0.218 & -0.111 & -0.067 & 0.038 & -0.095 \\
\hline v19 & -0.165 & 0.084 & 0.061 & -0.027 & 0.086 \\
\hline v21 & 0.269 & -0.137 & -0.105 & 0.056 & -0.149 \\
\hline v23 & 0.370 & -0.189 & -0.136 & 0.076 & -0.193 \\
\hline v24 & 0.381 & -0.195 & -0.141 & 0.063 & -0.200 \\
\hline v25 & 0.133 & -0.068 & -0.052 & 0.028 & -0.074 \\
\hline v26 & 0.450 & -0.230 & -0.138 & 0.079 & -0.196 \\
\hline v28 & 0.272 & -0.139 & -0.100 & 0.056 & -0.143 \\
\hline v31 & 0.278 & -0.142 & -0.102 & 0.057 & -0.145 \\
\hline v32 & -0.371 & 0.190 & 0.145 & -0.077 & 0.206 \\
\hline v33 & 0.217 & -0.111 & -0.085 & 0.045 & -0.120 \\
\hline v34 & 0.252 & -0.129 & -0.099 & -0.133 & -0.140 \\
\hline v35 & 0.112 & -0.057 & -0.042 & 0.019 & -0.059 \\
\hline
\end{tabular}

Fitted Covariance Matrix (continued)

$\begin{array}{lr} & \mathbf{v 1 6} \\ \text { v16 } & 1.000 \\ \text { v17 } & -0.012 \\ \text { v19 } & 0.009 \\ \text { v21 } & -0.015 \\ \text { v23 } & -0.021 \\ \text { v24 } & -0.022 \\ \text { v25 } & -0.008 \\ \text { v26 } & -0.025 \\ \text { v28 } & -0.015 \\ \text { v31 } & -0.016 \\ \text { v32 } & 0.021 \\ \text { v33 } & -0.012 \\ \text { v34 } & -0.014 \\ \text { v35 } & -0.006\end{array}$

$\mathbf{v 1 7}$
1.000
-0.064
0.111
0.144
0.149
0.055
0.146
0.106
0.108
-0.153
0.089
0.104
0.044

v19

v21

v23

v24

1.000

$-0.079$

$-0.109$

1.000

$-0.112$

0.221

0.183

0.080

-0.039
-0.133

0.080
0.229

$-0.080$

0.163

$-0.082$

0.166

0.109

$-0.224$

$-0.064$

0.131

$-0.074$

0.152

0.054

1.000

0.252

0.109

0.296

0.144

0.146

$-0.305$

0.178

0.207

0.074

v15

1.000

0.177

- -

$-$

$-$

$-$

-

$-$

$-$

$-$

$-$

Fitted Covariance Matrix (continued)

$\begin{array}{lrc} & \mathbf{v 2 5} & \text { v26 } \\ \text { v25 } & 1.000 & \\ \text { v26 } & 0.113 & 1.000 \\ \text { v28 } & 0.081 & 0.218 \\ \text { v31 } & 0.082 & 0.223\end{array}$

v28

v31

v32

v33 


\begin{tabular}{|c|c|c|c|c|c|}
\hline v32 & -0.111 & -0.315 & -0.225 & -0.229 & 1.000 \\
\hline v33 & -0.071 & 0.184 & 0.131 & 0.134 & -0.359 \\
\hline 34 & 0.075 & 0.214 & 0.153 & 0.156 & -0.210 \\
\hline v35 & 0.027 & 0.090 & 0.055 & 0.056 & -0.074 \\
\hline
\end{tabular}

1.000

0.123

0.044

Fitted Covariance Matrix (continued)

$\begin{array}{rrr}\text { v34 } & \text { v34 } & \text { v35 } \\ \text { v35 } & 1.000 & \\ 0.051 & 1.000\end{array}$

\section{Fitted Residuals}

v1
v3
v5
v6
v7
v8
v9
v11
v12
v13
v14
v15
v16
v17
v19
v21
v23
v24
v25
v26
v28
v31
v32
v33
v34
v35

Fitted Residuals (continued)

v1

0.000

$-0.042$

0.097

$-0.034$

0.057

0.003

$-0.013$

0.027

0.040

$-0.091$

0.073

0.017

-0.088
0.045

0.048

0.015

0.022

0.055

$-0.051$

$-0.086$

0.001

0.047

0.002

$-0.052$

0.011

0.042 v3

0.000

$-0.047$

$-0.052$

0.000

$-0.023$

0.007

$-0.022$

0.012

$-0.034$

$-0.023$

0.005

$-0.070$

$-0.013$

$-0.022$

$-0.045$

$-0.025$

0.046

0.086

$-0.008$

$-0.028$

0.014

$-0.019$

$-0.012$

$-0.052$

0.023 v5

0.000

$$
0.023
$$

0.063

$-0.030$

0.038

0.029

0.000

0.052

$-0.070$

$-0.034$

0.051

$-0.035$

0.039

0.002

$-0.063$

0.012

0.019

$-0.082$

$-0.013$

0.055

0.015

0.005

$-0.031$

$-0.008$ v6

v7

0.000

0.041

$-0.027$

$-0.111$

0.019

0.035

$-0.092$

$-0.022$

0.086

$-0.072$

$-0.023$

0.189

0.109

0.037

$-0.005$

$-0.038$

0.067

0.091

$-0.067$

0.069

0.034

0.046

0.090
0.000

$-0.114$

$-0.102$

$-0.142$

0.052

0.116

$-0.108$

0.038

$-0.003$

0.102

$-0.006$

$-0.052$

$-0.045$

$-0.054$

$-0.012$

0.041

$-0.075$

$-0.065$

$-0.059$

0.029

$-0.056$

$-0.041$

v8

0.000
-0.044
0.072
-0.046
0.171
-0.054
-0.080
0.026
0.021
-0.006
0.071
0.028
0.037
0.095
-0.015
-0.015
0.057
-0.006
-0.014
0.004
-0.013

v9
v11
$v 12$
$v 13$
$v 14$
$v 15$
$v 16$
$v 17$
$v 19$
$v 21$
v23
v24
v25

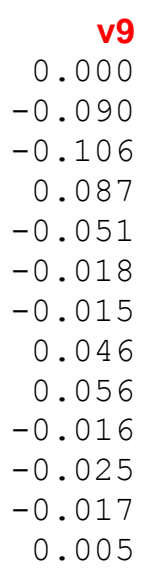

v11

v12

v13

v14

v15

0.000

$-0.151$

$-0.075$

0.066

0.000

$-0.016$

$-0.011$

$-0.049$

0.041

0.000

0.036

0.110

$-0.055$

0.012

$-0.061$

0.071

0.002

$-0.043$

0.032

$-0.064$

$-0.031$

0.031

$-0.007$

$-0.002$

0.041

$-0.124$

$-0.041$

$-0.008$

0.013

$-0.056$

0.022

0.095

0.048

$-0.025$

0.018 


\begin{tabular}{|c|c|c|c|c|c|c|}
\hline v26 & -0.037 & 0.015 & 0.035 & -0.153 & 0.014 & 0.023 \\
\hline v28 & -0.064 & 0.028 & -0.016 & -0.115 & 0.063 & -0.018 \\
\hline v31 & -0.015 & 0.067 & -0.011 & 0.076 & -0.014 & -0.116 \\
\hline v32 & -0.062 & 0.023 & 0.038 & -0.032 & -0.050 & 0.175 \\
\hline v33 & 0.006 & -0.031 & -0.039 & 0.048 & 0.032 & -0.153 \\
\hline v34 & -0.030 & 0.004 & 0.036 & 0.000 & 0.068 & 0.082 \\
\hline v35 & 0.003 & 0.062 & 0.025 & -0.008 & 0.030 & 0.183 \\
\hline
\end{tabular}

Fitted Residuals (continued)

\begin{tabular}{|c|c|c|c|c|c|c|}
\hline & v16 & v17 & v19 & v21 & v23 & v24 \\
\hline v16 & 0.000 & & & & & \\
\hline v17 & 0.165 & 0.000 & & & & \\
\hline v19 & -0.054 & -0.033 & 0.000 & & & \\
\hline v21 & 0.103 & -0.045 & -0.111 & 0.000 & & \\
\hline v23 & -0.114 & -0.066 & 0.047 & -0.011 & 0.000 & \\
\hline v24 & -0.072 & -0.055 & 0.032 & -0.018 & 0.136 & 0.000 \\
\hline v25 & 0.084 & 0.049 & -0.008 & -0.053 & -0.012 & 0.111 \\
\hline v26 & -0.025 & -0.007 & -0.001 & -0.078 & 0.083 & 0.068 \\
\hline v28 & -0.059 & -0.015 & -0.043 & 0.005 & 0.079 & 0.051 \\
\hline v31 & 0.082 & 0.005 & -0.091 & 0.173 & -0.046 & -0.052 \\
\hline v32 & 0.006 & 0.013 & 0.067 & -0.051 & 0.036 & 0.057 \\
\hline v33 & -0.013 & -0.039 & -0.048 & 0.065 & -0.015 & -0.075 \\
\hline v34 & -0.085 & -0.091 & 0.142 & 0.046 & 0.096 & 0.144 \\
\hline v35 & 0.061 & 0.109 & 0.039 & -0.007 & -0.004 & 0.0 \\
\hline
\end{tabular}

Fitted Residuals (continued)

\begin{tabular}{|c|c|c|c|c|c|c|}
\hline & v25 & v26 & v28 & v31 & v32 & v33 \\
\hline v25 & 0.000 & & & & & \\
\hline v26 & 0.073 & 0.000 & & & & \\
\hline v28 & 0.069 & 0.061 & 0.000 & & & \\
\hline v31 & -0.099 & -0.045 & -0.009 & 0.000 & & \\
\hline v32 & 0.111 & 0.053 & 0.028 & -0.129 & 0.000 & \\
\hline v33 & 0.000 & -0.026 & -0.045 & 0.073 & 0.000 & 0.000 \\
\hline v34 & 0.022 & 0.082 & 0.157 & -0.110 & 0.104 & -0.023 \\
\hline v35 & 0.168 & 0.048 & 0.032 & -0.056 & 0.100 & -0.073 \\
\hline
\end{tabular}

Fitted Residuals (continued)

$\begin{array}{lrr} & \text { v34 } & \text { v35 } \\ \text { v34 } & 0.000 & \\ \text { v35 } & 0.087 & 0.000\end{array}$

\section{Summary Statistics for Fitted Residuals}

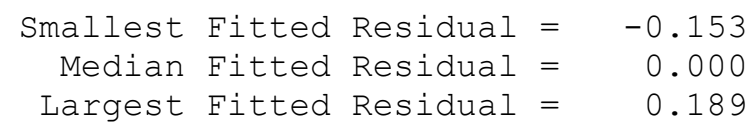

\section{Stemleaf Plot}




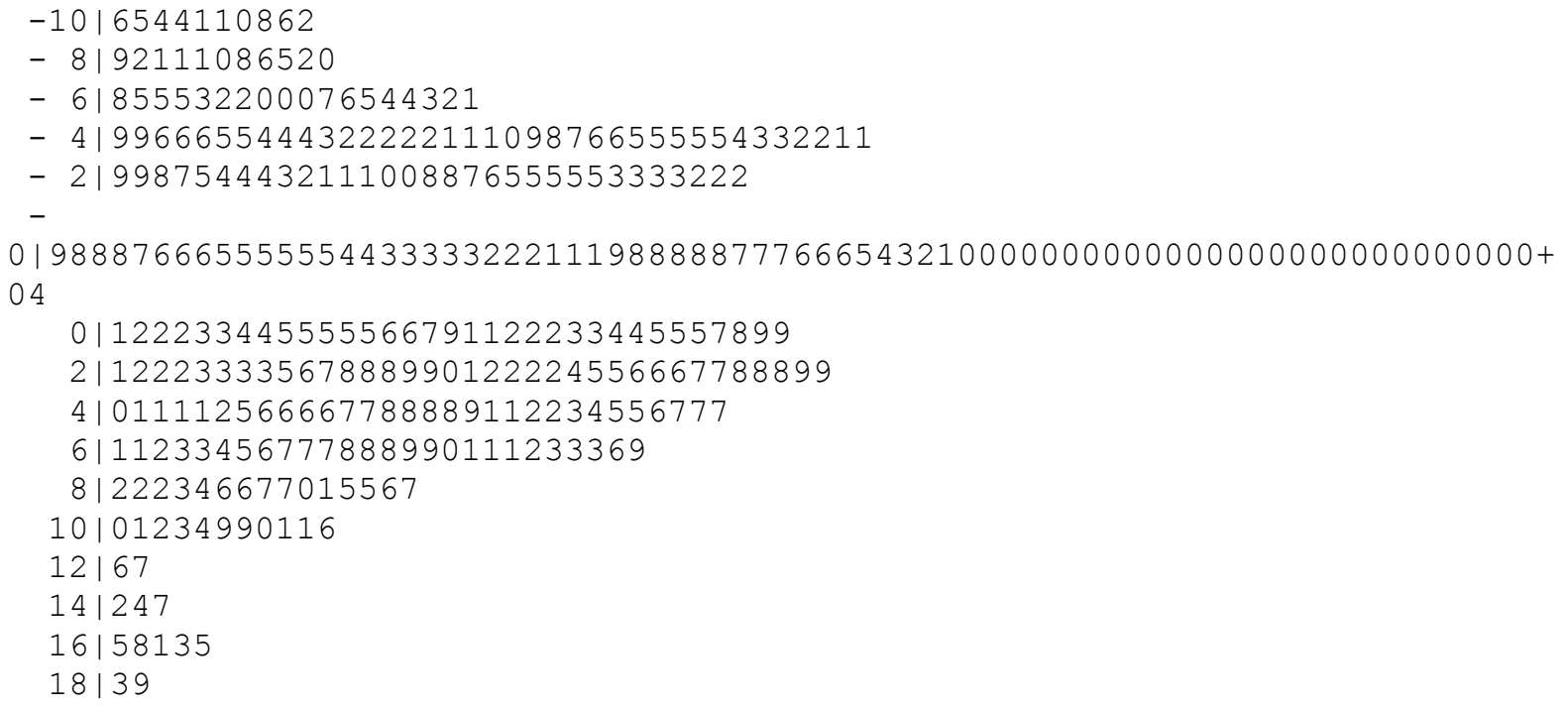

\section{Standardized Residuals}

\begin{tabular}{|c|c|c|c|c|c|c|}
\hline & v1 & v3 & v5 & v6 & v7 & v8 \\
\hline v1 & - & & & & & \\
\hline v3 & -1.241 & 0.000 & & & & \\
\hline v5 & 2.890 & -1.410 & - & & & \\
\hline v6 & -0.998 & -1.526 & 0.671 & 0.000 & & \\
\hline v7 & 1.790 & 0.003 & 2.058 & 1.276 & 0.000 & \\
\hline v8 & 0.093 & -0.664 & -0.901 & -0.784 & -3.718 & 0.000 \\
\hline v9 & -0.427 & 0.237 & 1.338 & -3.516 & -3.684 & -1.452 \\
\hline v11 & 0.816 & -0.670 & 0.897 & 0.563 & -4.680 & 2.168 \\
\hline v12 & 1.188 & 0.345 & 0.014 & 1.026 & 1.679 & -1.385 \\
\hline v13 & -2.681 & -0.989 & 1.547 & -2.696 & 3.696 & 5.047 \\
\hline v14 & 2.183 & -0.704 & -2.162 & -0.664 & -3.591 & -1.642 \\
\hline v15 & 0.499 & 0.144 & -1.000 & 2.523 & 1.111 & -2.346 \\
\hline v16 & -2.588 & -2.050 & 1.506 & -2.124 & -0.099 & 0.754 \\
\hline v17 & 1.330 & -0.393 & -1.063 & -0.672 & 3.312 & 0.628 \\
\hline v19 & 1.414 & -0.644 & 1.178 & 5.566 & -0.203 & -0.175 \\
\hline v21 & 0.440 & -1.363 & 0.063 & 3.268 & -1.757 & 2.177 \\
\hline v23 & 0.665 & -0.768 & -1.988 & 1.131 & -1.579 & 0.878 \\
\hline v24 & 1.696 & 1.424 & 0.371 & -0.151 & -1.837 & 1.152 \\
\hline v25 & -1.492 & 2.532 & 0.565 & -1.129 & -0.374 & 2.831 \\
\hline v26 & -2.647 & -0.253 & -2.698 & 2.070 & 1.489 & -0.466 \\
\hline v28 & 0.043 & -0.844 & -0.397 & 2.746 & -2.550 & -0.463 \\
\hline v31 & 1.422 & 0.420 & 1.709 & -2.010 & -2.214 & 1.730 \\
\hline v32 & 0.064 & -0.597 & 0.483 & 2.134 & -2.234 & -0.201 \\
\hline v33 & -1.554 & -0.355 & 0.160 & 1.002 & 0.985 & -0.434 \\
\hline v34 & 0.342 & -1.555 & -0.958 & 1.380 & -1.866 & 0.129 \\
\hline v35 & 1.239 & 0.691 & -0.254 & 2.649 & -1.316 & -0.373 \\
\hline
\end{tabular}

Standardized Residuals (continued)

$\begin{array}{lrrrrr} & \mathbf{v 9} & \mathbf{v 1 1} & \mathbf{v 1 2} & \mathbf{v 1 3} & \mathbf{v 1 4} \\ \text { v9 } & 0.000 & & & \\ \text { v11 } & -3.375 & 0.000 & & \\ \text { v12 } & -3.592 & -4.640 & -- & & \\ \text { v13 } & 2.762 & 0.330 & -2.225 & 0.000 & - \\ \text { v14 } & -1.817 & -0.509 & 2.067 & -1.474 & -1.619 \\ \text { v15 } & -0.522 & 1.061 & -0.312 & 1.207 & -19\end{array}$




$\begin{array}{lrrrrr}\text { v16 } & -0.484 & 0.373 & -1.810 & 3.225 & 0.060 \\ \text { v17 } & 1.563 & 0.289 & -1.274 & 2.111 & -0.986 \\ \text { v19 } & 1.907 & -1.299 & 0.949 & -1.909 & -0.076 \\ \text { v21 } & -0.528 & 2.169 & 0.960 & -0.227 & -1.261 \\ \text { v23 } & -0.942 & -0.251 & 1.281 & -3.833 & 0.708 \\ \text { v24 } & -0.710 & 1.751 & 0.412 & -1.721 & 3.058 \\ \text { v25 } & 0.147 & 1.439 & -0.841 & -0.735 & 0.553 \\ \text { v26 } & -1.470 & 0.484 & 1.204 & -4.764 & 0.533 \\ \text { v28 } & -2.297 & 0.861 & -0.488 & -3.488 & 1.957 \\ \text { v31 } & -0.518 & 2.064 & -0.350 & 2.315 & -0.423 \\ \text { v32 } & -2.187 & 0.744 & 1.192 & -1.013 & -1.613 \\ \text { v33 } & 0.190 & -0.935 & -1.176 & 1.435 & 0.992 \\ \text { v34 } & -1.002 & 0.122 & 1.087 & 0.000 & 2.090 \\ \text { v35 } & 0.118 & 1.882 & 0.757 & -0.247 & 0.916\end{array}$

$$
\begin{array}{r}
2.006 \\
--- \\
2.953 \\
-0.730 \\
-2.048 \\
1.872 \\
4.009 \\
0.670 \\
-0.541 \\
-3.406 \\
5.143 \\
-4.487 \\
2.408 \\
5.356
\end{array}
$$

\section{Standardized Residuals}

(continued)

$\begin{array}{lrr} & \text { v16 } & \text { v17 } \\ \text { v16 } & 0.000 & \\ \text { v17 } & 4.918 & - \\ \text { v19 } & -1.610 & -0.998 \\ \text { v21 } & 3.096 & -1.389 \\ \text { v23 } & -3.502 & -2.062 \\ \text { v24 } & -2.210 & -1.746 \\ \text { v25 } & 2.464 & 1.472 \\ \text { v26 } & -0.786 & -0.230 \\ \text { v28 } & -1.767 & -0.449 \\ \text { v31 } & 2.468 & 0.142 \\ \text { v32 } & 0.174 & 0.411 \\ \text { v33 } & -0.387 & -1.169 \\ \text { v34 } & -2.542 & -2.779 \\ \text { v35 } & 1.790 & 3.260\end{array}$

v19 v21 v23 v24

0.000
-3.360
1.453
1.006
-0.252
-0.027
-1.304
-2.783
2.077
-1.447
4.288
1.162

Standardized Residuals (continued)

$\begin{array}{lrrrrr} & \text { v25 } & \text { v26 } & \text { v28 } & \text { v31 } & \text { v32 } \\ \text { v25 } & 0.000 & & & & \\ \text { v26 } & 2.299 & -- & & & \\ \text { v28 } & 2.111 & 2.046 & 0.000 & & \\ \text { v31 } & -3.025 & -1.492 & -0.315 & 0.000 & \\ \text { v32 } & 3.460 & 1.821 & 0.942 & -4.336 & 0.000 \\ \text { v33 } & 0.000 & -0.831 & -1.396 & 2.278 & 0.000 \\ \text { v34 } & 0.664 & 2.669 & 4.964 & -3.442 & 3.357 \\ \text { v35 } & 4.984 & 1.567 & 0.985 & -1.691 & 3.104\end{array}$

$\begin{array}{rrr} & \text { v34 } & \text { v35 } \\ \text { v34 } & 0.000 & \\ \text { v35 } & 2.615 & --\end{array}$

\section{Summary Statistics for Standardized Residuals}

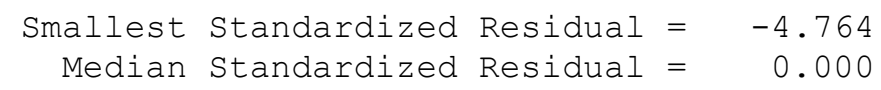




\section{Stemleaf Plot}

$-4 \mid 87653$

- $3 \mid 8776655544440$

- 2188777665553332222222111000

- $1 \mid 998888877777766666666555555444444333332221100000000$

$0 \mid 999888888777777777666555555555544444444444433333332222222211100000000000+$ 23

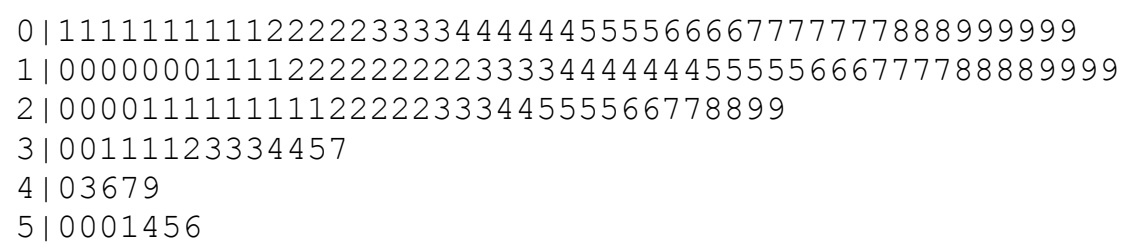

\section{Largest Negative Standardized Residuals}

Residual for

Residual for

Residual for

Residual for

Residual for

Residual for

Residual for

Residual for

Residual for

Residual for

Residual for

Residual for

Residual for

Residual for

Residual for

Residual for

Residual for

Residual for

Residual for

Residual for

Residual for

Residual for

Residual for

Residual for

Residual for

$\begin{array}{ll}\text { v8 } & \text { and } \\ \text { v9 } & \text { and } \\ \text { v9 } & \text { and } \\ \text { v11 } & \text { and } \\ \text { v11 } & \text { and } \\ \text { v12 } & \text { and } \\ \text { v12 } & \text { and } \\ \text { v13 } & \text { and } \\ \text { v13 } & \text { and } \\ \text { v14 } & \text { and } \\ \text { v16 } & \text { and } \\ \text { v21 } & \text { and } \\ \text { v23 } & \text { and } \\ \text { v23 } & \text { and } \\ \text { v26 } & \text { and } \\ \text { v26 } & \text { and } \\ \text { v26 } & \text { and } \\ \text { v28 } & \text { and } \\ \text { v31 } & \text { and } \\ \text { v31 } & \text { and } \\ \text { v31 } & \text { and } \\ \text { v32 } & \text { and } \\ \text { v33 } & \text { and } \\ \text { v34 } & \text { and } \\ \text { v34 } & \text { and }\end{array}$

$\begin{aligned} \text { v7 } & -3.718 \\ \text { v6 } & -3.516 \\ \text { v7 } & -3.684 \\ \text { v7 } & -4.680 \\ \text { v9 } & -3.375 \\ \text { v9 } & -3.592 \\ \text { v11 } & -4.640 \\ \text { v1 } & -2.681 \\ \text { v6 } & -2.696 \\ \text { v7 } & -3.591 \\ \text { v1 } & -2.588 \\ \text { v19 } & -3.360 \\ \text { v13 } & -3.833 \\ \text { v16 } & -3.502 \\ \text { v1 } & -2.647 \\ \text { v5 } & -2.698 \\ \text { v13 } & -4.764 \\ \text { v13 } & -3.488 \\ \text { v15 } & -3.406 \\ \text { v19 } & -2.783 \\ \text { v25 } & -3.025 \\ \text { v31 } & -4.336 \\ \text { v15 } & -4.487 \\ \text { v17 } & -2.779 \\ \text { v31 } & -3.442\end{aligned}$

\section{Largest Positive Standardized Residuals}

Residual for

Residual for

Residual for

Residual for

Residual for

Residual for

Residual for

Residual for

$\begin{array}{ll}\mathbf{v} 5 & \text { and } \\ \mathbf{v 1 3} & \text { and } \\ \mathbf{v 1 3} & \text { and } \\ \mathbf{v 1 3} & \text { and } \\ \mathbf{v} 16 & \text { and } \\ \mathbf{v 1 7} & \text { and } \\ \mathbf{v 1 7} & \text { and } \\ \mathbf{v} 19 & \text { and }\end{array}$

v1

2.890

v7

3.696

5.047

v8

2. 762

3.225

v13

3. 312

v7

4.918

v16

5.566 
Residual for

Residual for

Residual for

Residual for

Residual for

Residual for

Residual for

Residual for

Residual for

Residual for

Residual for

Residual for

Residual for

Residual for

Residual for

Residual for

Residual for

Residual for

Residual for

Residual for

Residual for

Residual for

Residual for

Residual for

Residual for

Residual for

$\begin{array}{ll}\text { v19 } & \text { and } \\ \text { v21 } & \text { and } \\ \text { v21 } & \text { and } \\ \text { v24 } & \text { and } \\ \text { v24 } & \text { and } \\ \text { v25 } & \text { and } \\ \text { v25 } & \text { and } \\ \text { v25 } & \text { and } \\ \text { v26 } & \text { and } \\ \text { v28 } & \text { and } \\ \text { v28 } & \text { and } \\ \text { v31 } & \text { and } \\ \text { v32 } & \text { and } \\ \text { v32 } & \text { and } \\ \text { v34 } & \text { and } \\ \text { v34 } & \text { and } \\ \text { v34 } & \text { and } \\ \text { v34 } & \text { and } \\ \text { v34 } & \text { and } \\ \text { v34 } & \text { and } \\ \text { v35 } & \text { and } \\ \text { v35 } & \text { and } \\ \text { v35 } & \text { and } \\ \text { v35 } & \text { and } \\ \text { v35 } & \text { and } \\ \text { v35 } & \text { and }\end{array}$

v15

v6

v16

v14

v23

v8

v15

v24

v23

v6

v23

v21

v15

v25

v19

v23

v24

v26

v28

v32

v6

v15

v17

v25

v32

v34
2. 953

3. 268

3. 096

3.058

4.677

2. 831

4. 009

3. 414

2. 930

2. 746

2. 983

5. 518

5.143

3. 460

4. 288

3.136

4. 560

2. 669

4. 964

3. 357

2. 649

5. 356

3. 260

4. 984

3. 104

2. 615

!Luciana CFA

\section{Qplot of Standardized Residuals}

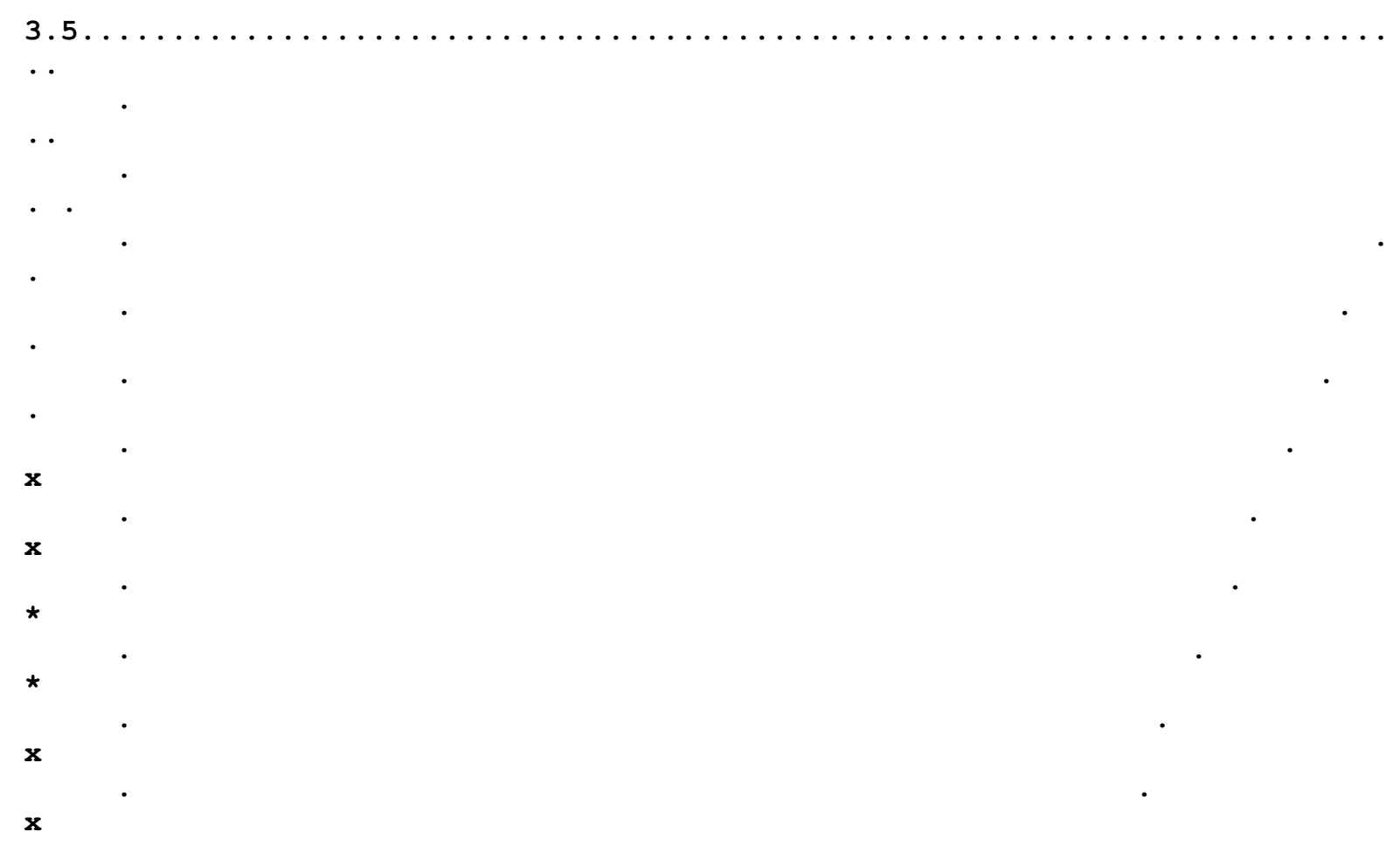




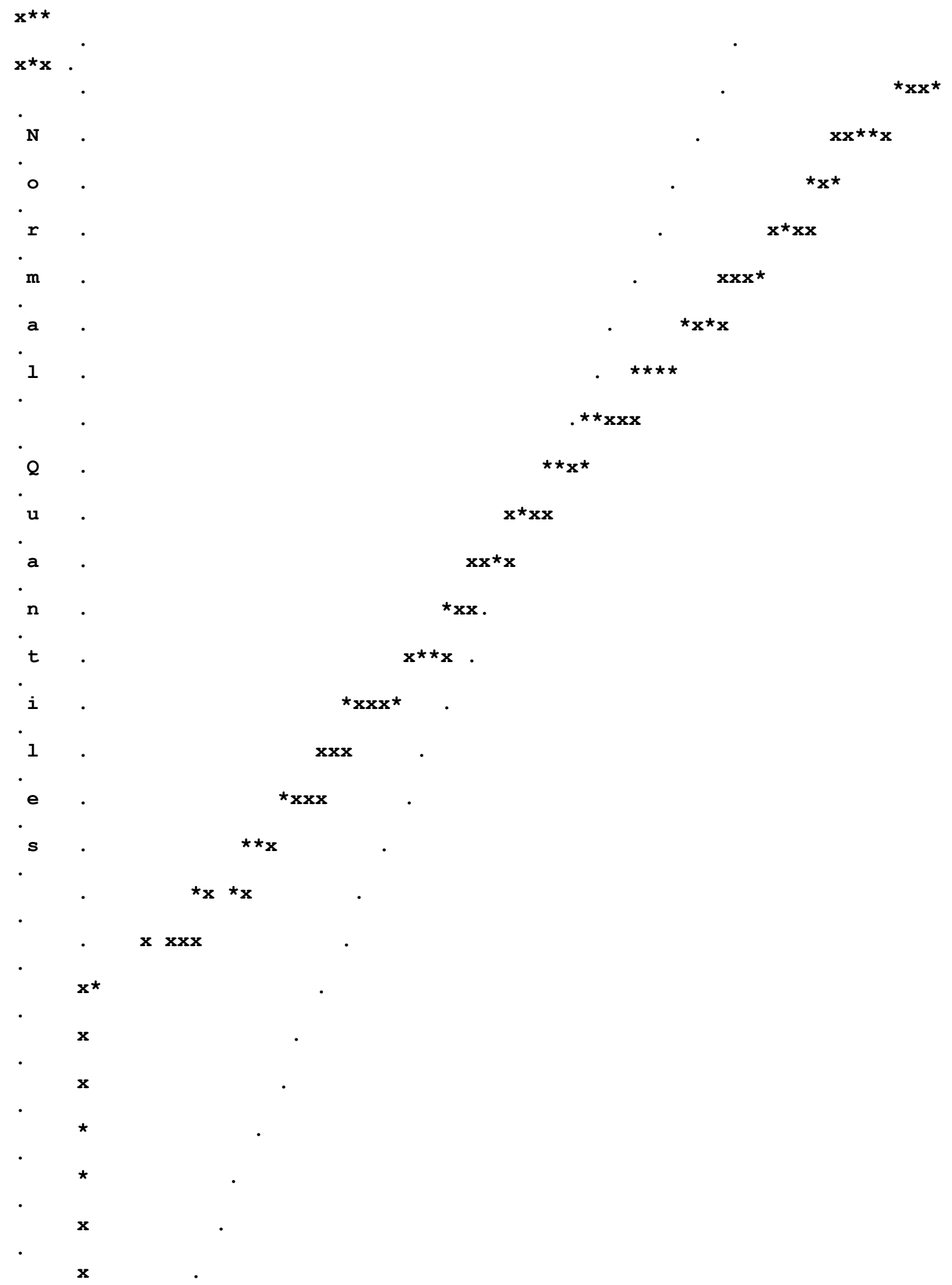


$-3.5$

3.5

The Modification Indices Suggest to Add an Error Covariance

\begin{tabular}{|c|c|c|c|}
\hline Between & and & Decrease in Chi-Square & New Estimate \\
\hline v5 & v1 & 8.4 & 0.10 \\
\hline v8 & v7 & 13.8 & -0.14 \\
\hline v9 & v6 & 12.4 & -0.13 \\
\hline v9 & v7 & 13.6 & -0.16 \\
\hline v11 & v7 & 21.9 & -0.18 \\
\hline v11 & v9 & 11.4 & -0.15 \\
\hline v12 & v9 & 12.9 & -0.14 \\
\hline v12 & v11 & 21.5 & -0.17 \\
\hline v13 & v7 & 13.7 & 0.14 \\
\hline v13 & v8 & 25.5 & 0.17 \\
\hline v14 & v7 & 12.9 & -0.14 \\
\hline v16 & v13 & 10.4 & 0.11 \\
\hline v17 & v7 & 11.0 & 0.13 \\
\hline v17 & v16 & 24.2 & 0.17 \\
\hline v19 & v6 & 31.0 & 0.19 \\
\hline v19 & v15 & 8.7 & 0.10 \\
\hline v21 & v6 & 10.7 & 0.11 \\
\hline v21 & v16 & 9.6 & 0.11 \\
\hline v21 & v19 & 11.3 & -0.12 \\
\hline v23 & v13 & 14.7 & -0.14 \\
\hline v23 & v16 & 12.3 & -0.13 \\
\hline v24 & v14 & 9.4 & 0.12 \\
\hline v24 & v23 & 21.9 & 0.19 \\
\hline v25 & v8 & 8.0 & 0.10 \\
\hline v25 & v15 & 16.1 & 0.14 \\
\hline v25 & v24 & 11.7 & 0.12 \\
\hline v26 & v13 & 22.7 & -0.17 \\
\hline v26 & v23 & 8.6 & 0.12 \\
\hline v28 & v13 & 12.2 & -0.12 \\
\hline v28 & v23 & 8.9 & 0.13 \\
\hline v31 & v15 & 11.6 & -0.12 \\
\hline v31 & v21 & 30.5 & 0.20 \\
\hline v31 & v25 & 9.2 & -0.11 \\
\hline v32 & v15 & 26.5 & 0.18 \\
\hline v32 & v25 & 12.0 & 0.13 \\
\hline v32 & v31 & 18.8 & -0.17 \\
\hline v33 & v15 & 20.1 & -0.15 \\
\hline v34 & v19 & 18.4 & 0.15 \\
\hline v34 & v23 & 9.8 & 0.12 \\
\hline v34 & v24 & 20.8 & 0.17 \\
\hline v34 & v28 & 24.6 & 0.18 \\
\hline v34 & v31 & 11.8 & -0.13 \\
\hline v34 & v32 & 11.3 & 0.13 \\
\hline v35 & v15 & 28.7 & 0.18 \\
\hline v35 & v17 & 10.6 & 0.11 \\
\hline v35 & v25 & 24.8 & 0.17 \\
\hline v35 & v32 & 9.6 & 0.11 \\
\hline
\end{tabular}

